
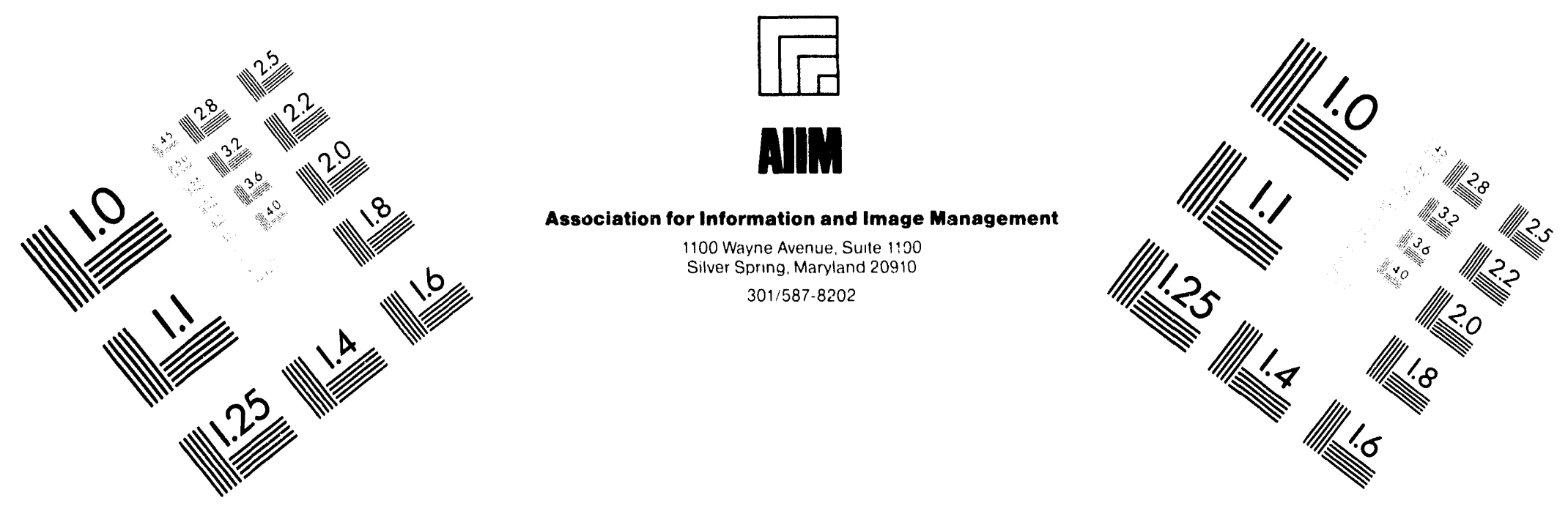

\title{
Centimeter
} |ши Inches
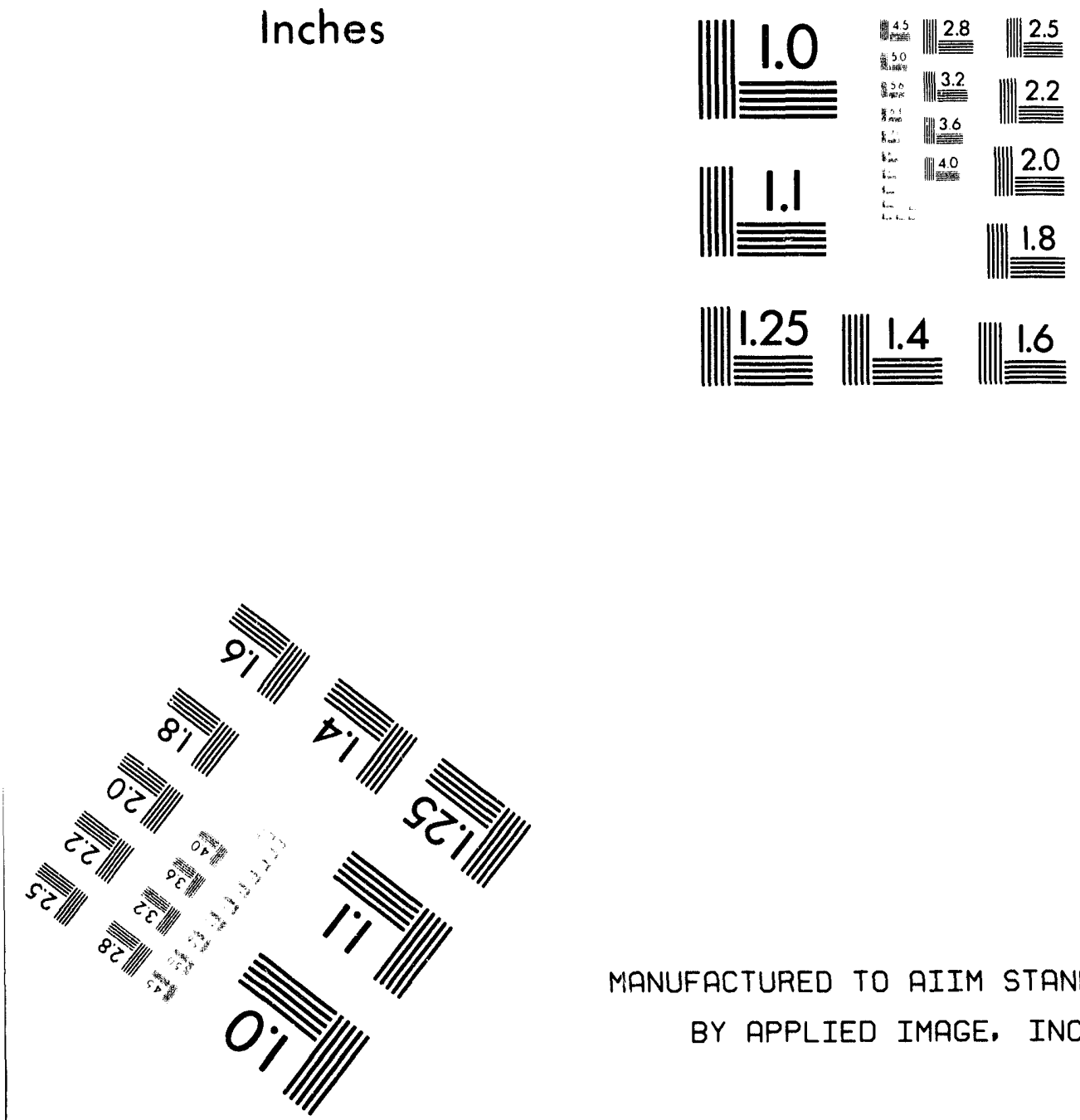

MANUFACTURED TO AIIM STANDARDS

BY APPLIED IMAGE, INC.

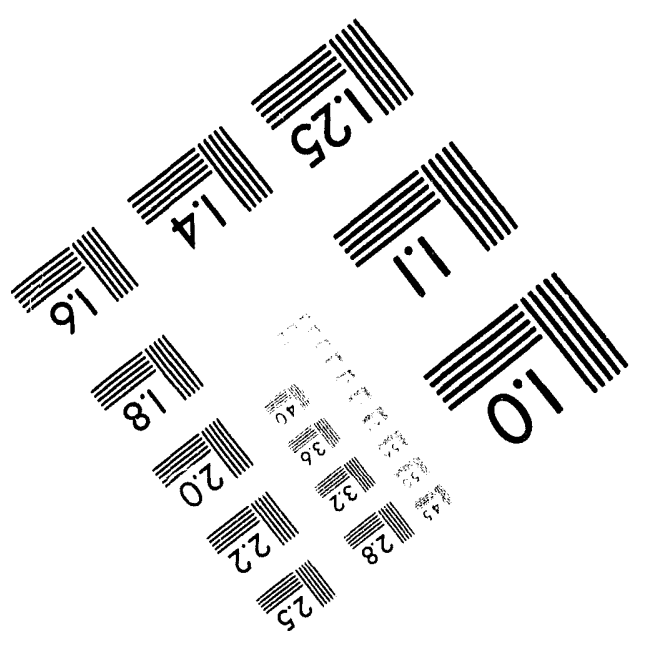



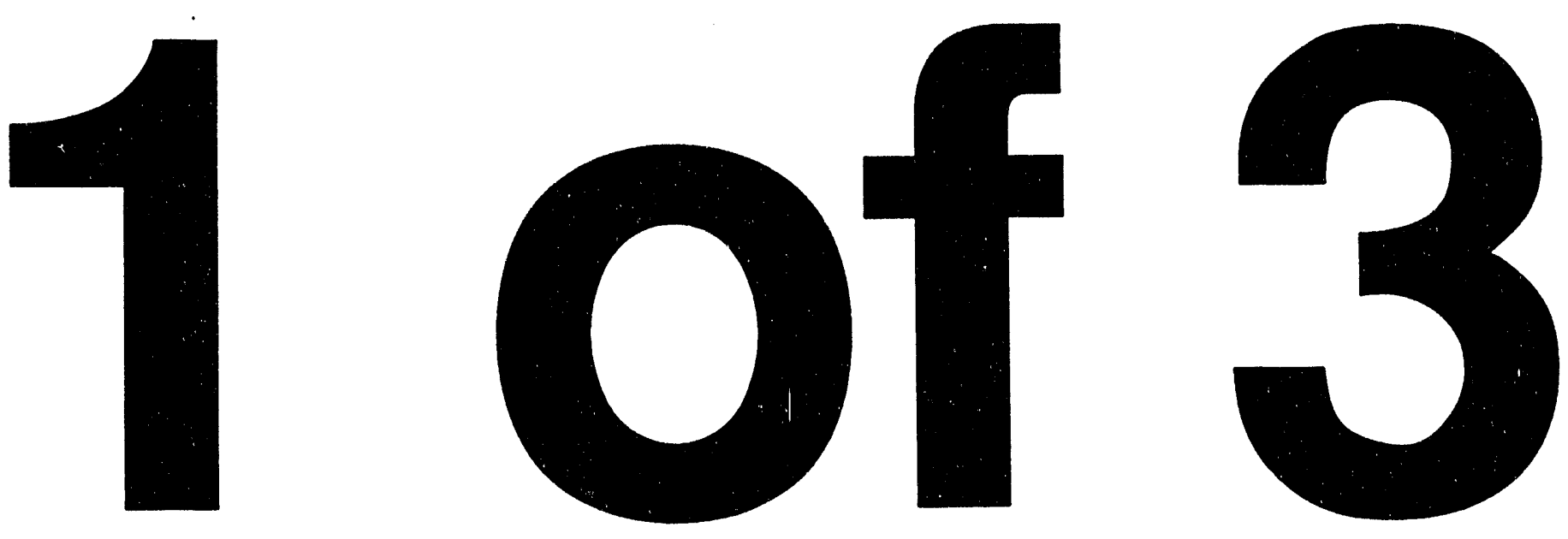
WHC-MR-0438

\section{Type B Investigation Report for 241-SY-101 Pump Start and 241-C-106 Pit Cleanout}

Date Published

September 1993

Prepared for the U.S. Department of Energy Office of Environmental Restoration and Waste Management

\section{(29) Westinghouse P.O. Box 1970 \\ Hanford Company Richland, Washington 99352 \\ Hanford Operations and Engineeri. I Contractor for the \\ U.S. Department of Energy under Contr: Ct DE-AC06-87RL10930}

Approved for Public Release 


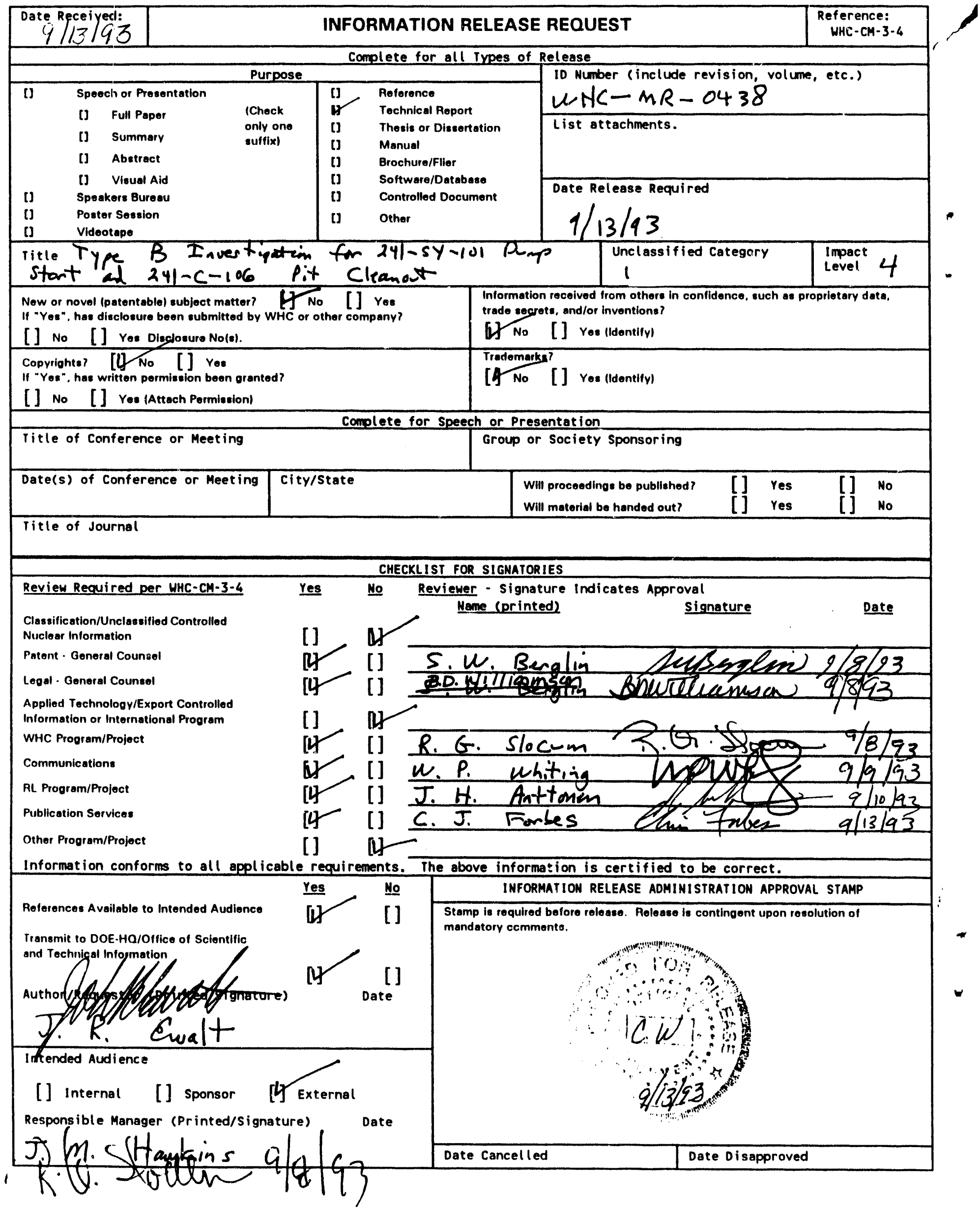




\section{CONTENTS}

1.0 INVESTIGATION SCOPE AND METHODOLOGY $\ldots \ldots \ldots \ldots \ldots \ldots \ldots$

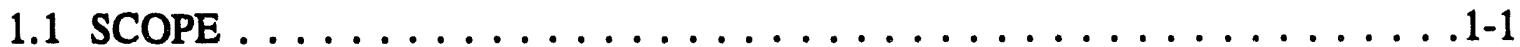

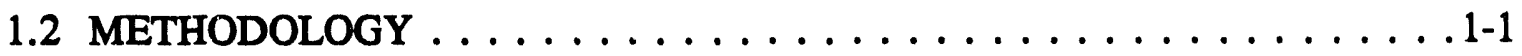

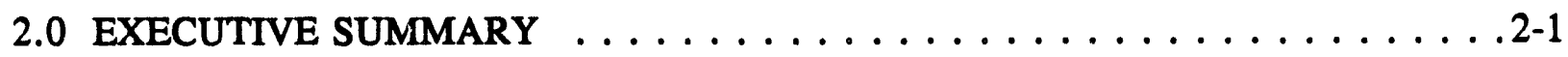

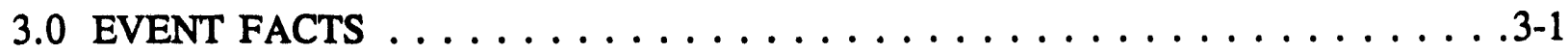

3.1 CHRONOLOGY OF THE INADVERTENT START

OF 241-SY-101 MTXER PUMP $\ldots \ldots \ldots \ldots \ldots \ldots \ldots \ldots \ldots$. . . . . .

3.1.1 Background Information $\ldots \ldots \ldots \ldots \ldots \ldots \ldots \ldots . \ldots \ldots$

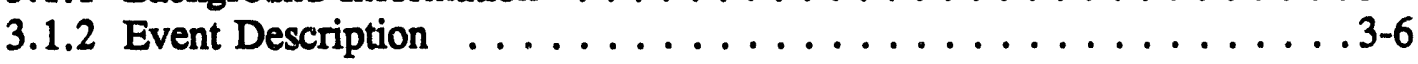

3.2 CHRONOLOGY OF THE 241-C-106 PERSONNEL

CONTAMINATION EVENT $\ldots \ldots \ldots \ldots \ldots \ldots \ldots \ldots \ldots \ldots \ldots$

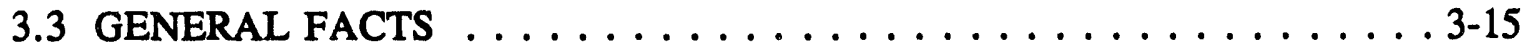

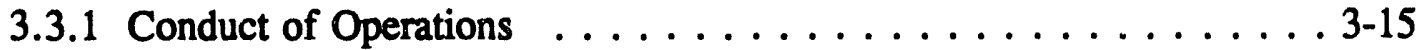

3.3.2 Safet . . . . . . . . . . . . . . . . . . . 3-19

3.3.3 Management Organization . . . . . . . . . . . . 3-21

3.3.4 Management Process $\ldots \ldots \ldots \ldots \ldots \ldots \ldots \ldots \ldots \ldots . \ldots \ldots$

3.3.5 Radiological Practices . . . . . . . . . . . . . . . . 3-26

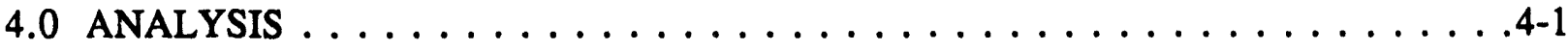

4.1 241-SY-101 ANALYSIS $\ldots \ldots \ldots \ldots \ldots \ldots \ldots \ldots \ldots . \ldots \ldots$. . . . . . . .

4.2 TANK 241-C-106 HEEL PIT CONTAMINATION EVENT $\ldots \ldots \ldots \ldots .4$.8

4.3 GENERAL FACTS ANALYSIS $\ldots \ldots \ldots \ldots \ldots \ldots \ldots \ldots \ldots$ 4-14

4.3.1 Conduct of Operations $\ldots \ldots \ldots \ldots \ldots \ldots \ldots \ldots \ldots$ 4-15

4.3.2 Safety . . . . . . . . . . . . . . . . . . 4-15

4.3.3 Management . . . . . . . . . . . . . . . 4-16

4.3.4 Management Processes $\ldots \ldots \ldots \ldots \ldots \ldots \ldots \ldots \ldots \ldots . . \ldots$ 4-18

4.3.5 Radiological Practices . . . . . . . . . . . . . . . . 4-19

4.4 ANALYSIS OF ROOT CAUSES $\ldots \ldots \ldots \ldots \ldots \ldots \ldots \ldots \ldots \ldots$ 4-20 $\ldots \ldots \ldots$

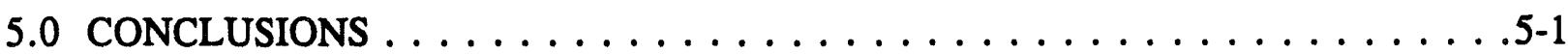

5.1 FINDINGS FOR 241 -SY-101 EVENT $\ldots \ldots \ldots \ldots \ldots \ldots \ldots \ldots \ldots$. $\ldots \ldots$

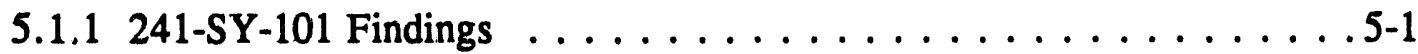

5.2 FINDINGS FOR 24 i-C-106 EVENT $\ldots \ldots \ldots \ldots \ldots \ldots \ldots \ldots$ 5-3

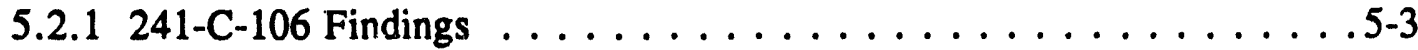

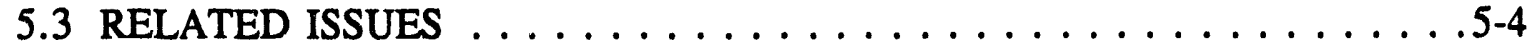

5.3.1 Conduct of Operations $\ldots \ldots \ldots \ldots \ldots \ldots \ldots .4 \ldots \ldots \ldots$

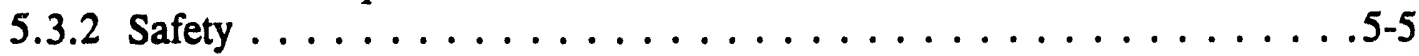

5.3 .3 Management . . . . . . . . . . . . . . . . 5-6

5.3.4 Radiological Practices . . . . . . . . . . . . . 5-6 


\section{CONTENTS (Continued)}

\section{APPENDIXES}

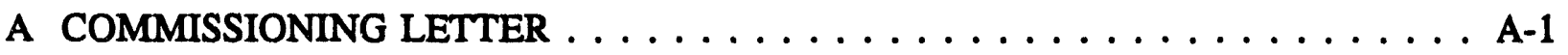

B BOARD MEMBERS $\ldots \ldots \ldots \ldots \ldots \ldots \ldots \ldots \ldots \ldots \ldots \ldots \ldots$

C ORGANIZATION CHARTS $\ldots \ldots \ldots \ldots \ldots \ldots \ldots \ldots \ldots \ldots \ldots$

D INTERVIEWEES $\ldots \ldots \ldots \ldots \ldots \ldots \ldots \ldots \ldots \ldots \ldots \ldots \ldots \ldots \ldots \ldots$

E NEWS RELEASES $\ldots \ldots \ldots \ldots \ldots \ldots \ldots \ldots \ldots \ldots \ldots \ldots$

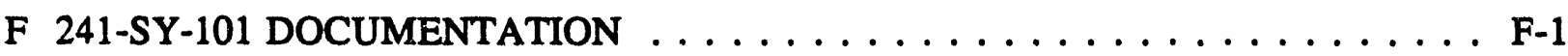

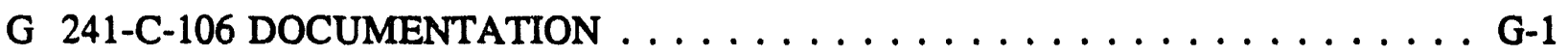

\section{LIST OF FIGURES}

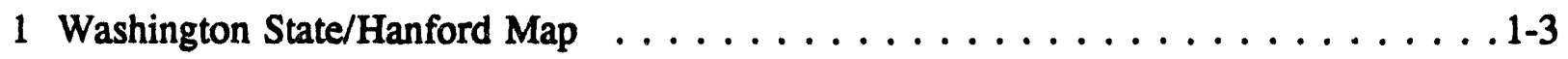

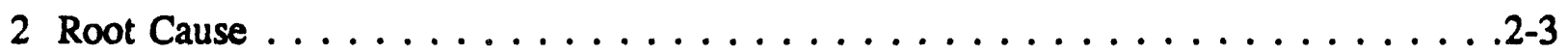

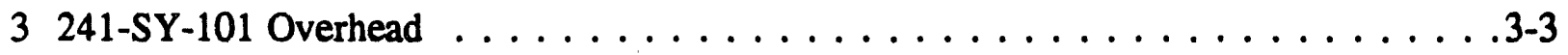

4 241-SY-101 Cross-section of Mitigation Mixer Pump . . . . . . . . . . . . . . 3-4

5 Simplified Electrical Diagram $\ldots \ldots \ldots \ldots \ldots \ldots \ldots \ldots \ldots \ldots$

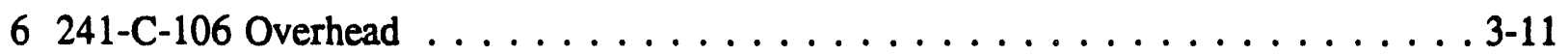

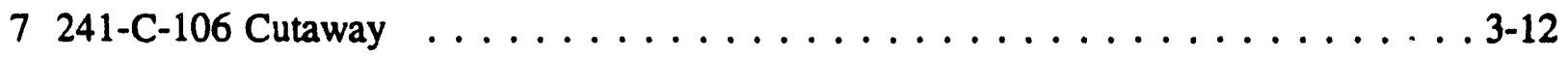

8 Heel Pit Penetration Cross-Section $\ldots \ldots \ldots \ldots \ldots \ldots \ldots \ldots$. . . . . . . . . . . . .

9 Event and Causal Factors Chart for 241-SY-101 . . . . . . . . . . . . . 4-2

10 Event and Causal Factors Chart for $241-\mathrm{C}-106 \ldots \ldots \ldots \ldots$ 


\section{LIST OF ACRONYMS}

$\begin{array}{ll}\text { ALARA } & \text { As Low As Reasonably Achievable } \\ \text { ATP } & \text { Acceptance Test Procedure } \\ \text { DACS } & \text { Data Acquisition and Control System } \\ \text { dpm } & \text { Disintegrations Per Minute } \\ \text { ECN } & \text { Engineering Change Notice } \\ \text { HP } & \text { Health Physics } \\ \text { HPT } & \text { Health Physics Technician } \\ \text { KEH } & \text { Kaiser Engineers Hanford } \\ \text { LANL } & \text { Los Alamos National Laboratory } \\ \text { LOI } & \text { Letter of Instruction } \\ \text { MORT } & \text { Management Oversight and Risk Tree } \\ \text { PIC } & \text { Person in Charge } \\ \text { POC } & \text { Point of Contact } \\ \text { RPR } & \text { Radiological Problem Report } \\ \text { RWP } & \text { Radiological Work Permit } \\ \text { SCBA } & \text { Self Contained Breathing Apparatus } \\ \text { SOI } & \text { Standard Operating Instruction } \\ \text { SWP } & \text { Special Work Permit (protective clothing) } \\ \text { TRC } & \text { Total Recordable Cases } \\ \text { TRG } & \text { Test Review Group } \\ \text { TWRS } & \text { Tank Waste Remediation System } \\ \text { WHC } & \text { Westinghouse Hanford Company } \\ \text { WTP } & \text { Waste Tank Project }\end{array}$


This page intentionally left blank. 


\section{TYPE B INVESTIGATION REPORT FOR 241-SY-101 PUMP START AND 241-C-106 PIT CLEANOUT}

\subsection{INVESTIGATION SCOPE AND METHODOLOGY}

\subsection{SCOPE}

The Investigative Board for the Type B Investigation Report for 241-SY-101 Pump Start and 241-C-106 Pit Cleanout was tasked specifically to look at two events:

- "Inadvertent Mixer Pump Operation at 241-SY-101" (RL-WHC-TANK-FARM-1993-069)

- "Inadequate Work Control Results in Personnel Skin Contamination at 241-C-106, Pit B" (RL-WHC-TANK-FARM-1993-071).

The Board was requested to fully explain the elements of the causal factors for these events and describe the management systems that should have or could have prevented the occurrences. Finally, the Board was requested to examine safety issues arising from these events in the Hanford Site tank farms. The review was focused on (1) Westinghouse Hanford Company (WHC) organizations performing operations, maintenance, and radiological safety tasks; and (2) Kaiser Engineers Hanford (KEH) organizations performing major maintenance tasks.

\subsection{METHODOLOGY}

The Board performed an initial review of the 241-SY-101 mixing pump and 241-C-106 pit events, as well as a review of the tank farms DOE 5000.3B occurrence reports issued for calendar year 1993. The Board focused generally on identification of common causal factors in these events, and specifically on deficiencies in or failures of management controls and barriers. These deficiencies/failures were grouped into topical areas that the Board determined as warranted for further investigation. The initial topical areas were contamination and safety awareness, configuration controls (equipment status awareness), and organizational structure (command and control). As the investigation progressed, these topical areas were refined.

An events and causal factors chart had already been prepared for the 241-SY-101 event by an internal WHC investigation. The Board reviewed this chart and accepted it with minor modifications. The Board developed an events and causal factors chart for the 241-C-106 event. The Board did not perform a separate formal barrier analysis for the two events. The events and causal factors analysis did consider barrier and control failures. 
Based on the topical areas identified in the preliminary reviews, the Board conducted interviews with WHC and $\mathrm{KEH}$ personnel. An interview list is provided in Appendix D to this report. A broad cross section of organizations and personnel were involved in the interviews, in order for the Board to understand the climate and attitude factors that influenced the events. In addition to the interviews, field visits and documentation reviews were conducted.

The Board conducted a Management Oversight and Risk Tree (MORT) analysis of the 241-SY-101 and the 241-C-106 events. MORT analysis is a structured method to evaluate both safety program and management system elements. It is axiomatic that deficiencies identified at lower levels are most generally reflections of problems in higher-tier systems. During the preparation of the investigation report the Board felt that, in order to fully fulfill its charter, it was necessary to provide separate descriptions, analyses, and findings for the 241-SY-101 and 241-C-106 events. However, these should be viewed in the context of the general analyses and findings of this report. 
Figure 1. Washington State/Hanford Map.

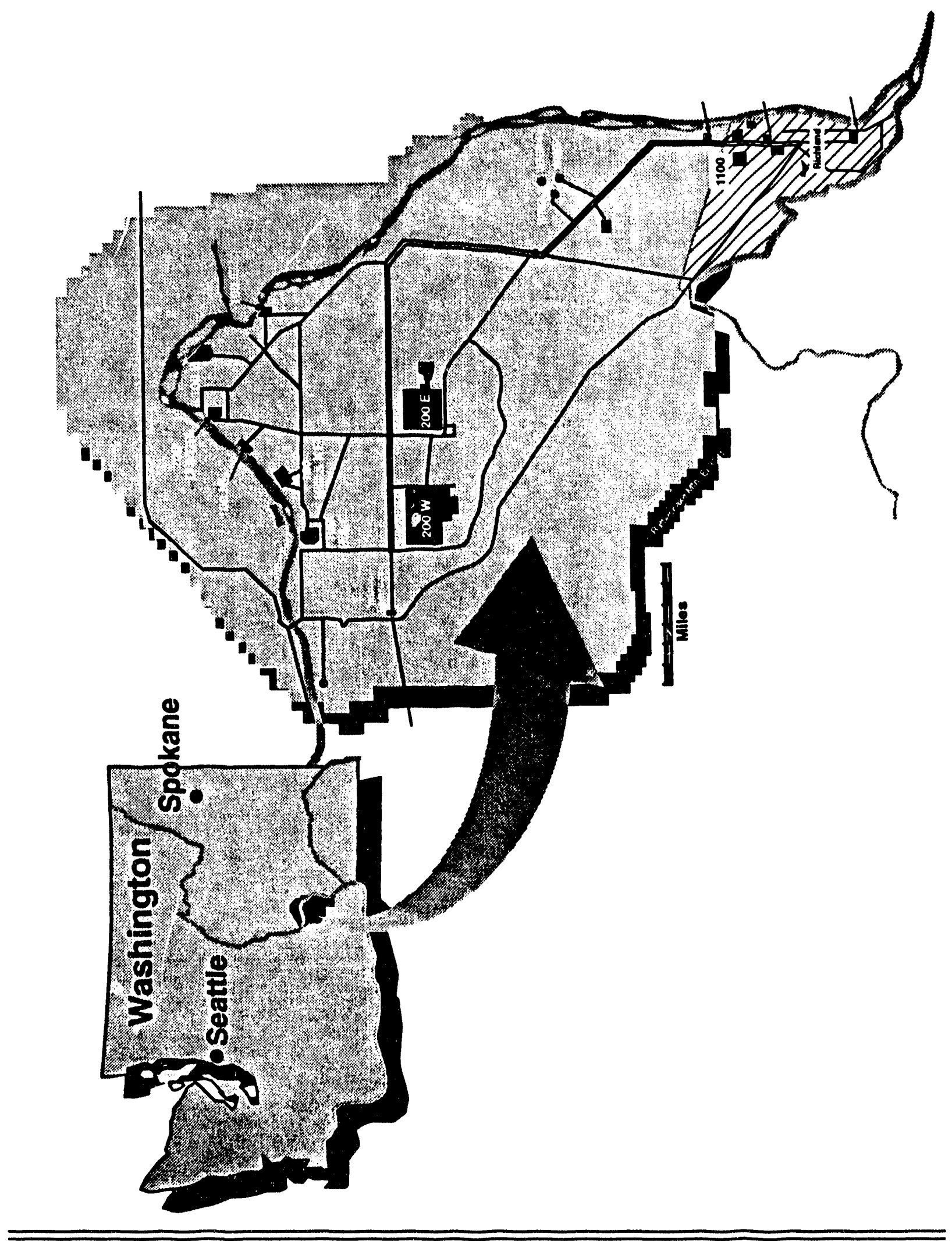


TYPE B INVESTIGATION REPORT FOR 241-SY-101 PUMP

START AND 241-C-106 PIT CLEANOUT

This page intentionally left blank. 


\subsection{EXECUTIVE SUMMARY}

In accordance with the direction of the Department of Energy (DOE) Manager, Richland Operations Office, a Type "B" investigation in accordance with the DOE Order 5484.1, Environmental Protection, Safety and Health Protection Information Reporting Requirements, has been conducted. The scope of the investigation included two events:

- The "Inadvertent Mixer Pump Operation at 241-SY-101" (RL-WHC-TANK FARM-1993-(0.59)

- $\quad$ "Inadequate Work Control Results in Personnel Skin Contamination at 241-C-106, Pit B" (RL-WHC-TANK FARM-1993-071) events.

Additionally, at the request of the President of the WHC, a broader investigation into Waste Tank Farm "safety practices" and "Conduct of Operations" was also conducted. The review was focused on (1) WHC organizations performing operations, maintenance, and radiological safety tasks; and (2) KEH organizations performing major maintenance tasks.

The investigation Board consisting of a Chairman, six committee members, and a DOE observer was convened and briefed on the purpose of the investigation on Monday, August 16, 1993. Brief resumes of the board membership are contained as Appendix B to this report.

The manner in which the investigation was conducted included (1) tours of the accessible event sites and other Hanford Site Tank Farm areas; (2) reviews of event reports; (3) reviews of procedures, organization charts, critique reports, and other documents; (4) interviews with personnel directly involved with events, as well as workers and managers in other areas of the tank farms; and (5) observation of work activities. While this investigation was being conducted, the tank farm work activities that were not considered essential to safety had been placed on administrative hold by WHC management; therefore, very little work was in progress at the time of the investigation.

As a result of the review of the information gathered in the early stages of the investigation, the scope of the investigation was expanded to include Management Practices and Radiological Practices.

This report contains a detailed analysis of the events, their causal factors, and the management systems that should have or could have prevented the events. Additionally, a detailed analysis of Conduct of Operations, Safety, Management Practices, and Radiological Practices is included. Specific findings and judgments of need are provided for the events and, as appropriate, for Conduct of Operations, Safety, Management, and Radiological Practices. 
It is the opinion of the Type " $\mathrm{B}$ " investigation Board that these events, as well as previous events, have common causes (Figure 2). These include:

- Inadequate management communication and field oversight

- Inadequate understanding and implementation of the principles of Conduct of Operations

- Tolerance for long-standing degraded plant and equipment conditions and inadequate management processes.

This triad of common causes has resulted in a lack of sensitivity of all personnel, including management, to safety and radiological hazards and the need to stop and consult with other expert personnel when unusual or unanticipated conditions are encountered. The result is that personnel attempt to solve issues on their own, without obtaining full knowledge of the results of their actions. Thus, events have occurred and will continue to occur unless the causal triad and its eifect, the lack of sensitivity, is addressed as an interactive relationship.

Examples of the results of this relationship are:

1. The failure to recognize that water in the 241-C-106 pit or lowering a rock into the 241-C-106 tank constituted an event that significantly changed and went beyond the work scope.

2. The spread of radioactive contamination across fields and roadways.

3. The failure to install adequate lighting or walkways in the tank farms.

4. The continued use of inadequate personal safety and radiological work practices.

5. The inadequate communications between field workers and management, and between field organizations.

Specific judgments of need for the findings concerning each event and program evaluated are contained in this report.

The investigation committee strongly recommends the formulation of groups consisting of workers and management to work together to develop the means to correct both material conditions and unacceptable work practices prior to the resumption of work activities in the Hanford Site tank farms. 
Figure 2. Root Cause.

\section{Inadequate Management Communication and Field Oversight}

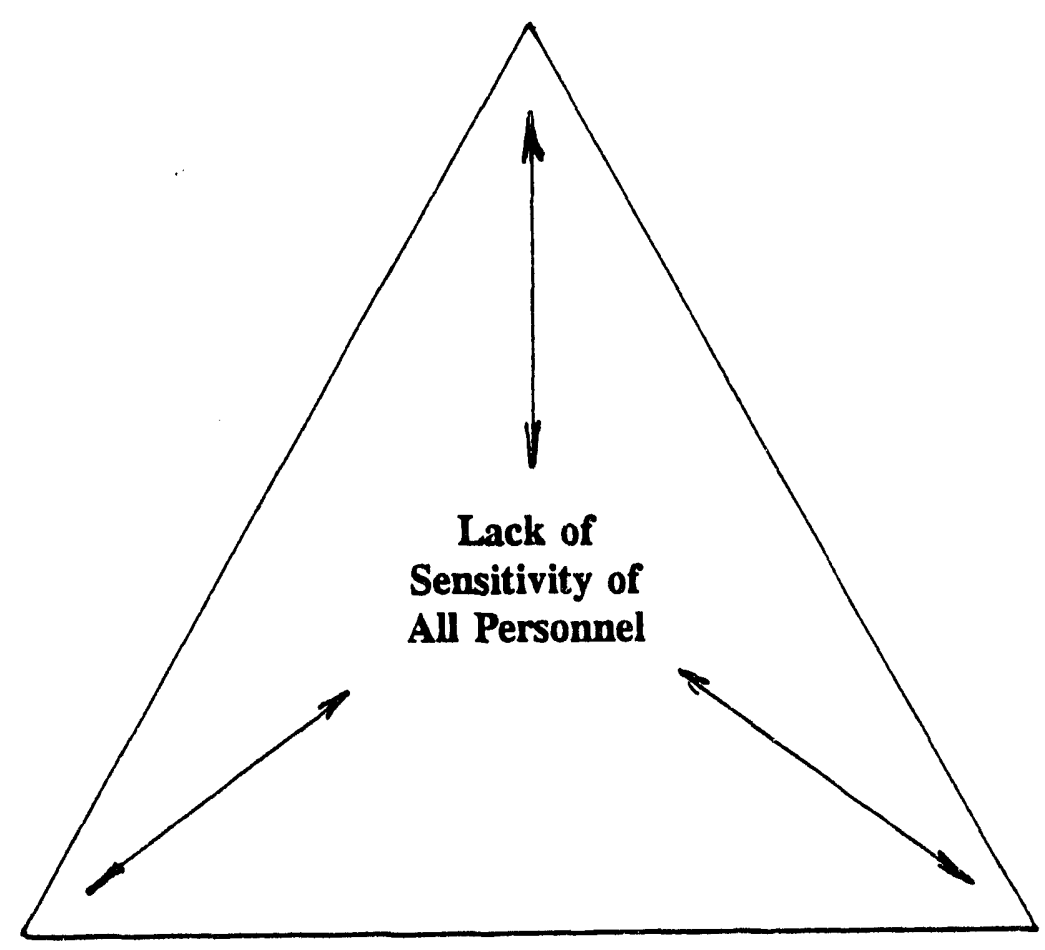

Tolerance for Degraded Plant and Equipment Conditions and for Inadequate Management Processes
Inadequate Understanding and Implementation of the Principles of Conduct of Operations Philosophy 
This page intentionally left blank. 


\subsection{EVENT FACTS}

\subsection{CHRONOLOGY OF THE INADVERTENT START OF 241-SY-101 MIXER PUMP}

\subsubsection{Background Information}

The mixer pump for waste tank 241-SY-101 was installed on July 3, 1993 (Figures 3 and 4). The installation occurred later than had been originally planned. The first intended installation had extensive readiness preparations and reviews, and these were updated for the delayed installation.

The pump was installed to mix tank contents in order to prevent the periodic release of hydrogen gas. There was an initial phase A test program to check the pump operation in the tank. The next phase of test was the Acceptance Test Procedure (ATP) on the data acquisition and control system (DACS). A phase B test is planned to further check out the pump and its ability to control periodic hydrogen gas releases. Activities for these phases were analyzed in a Safety Assessment prepared by Los Alamos National Laboratory (LANI.).

The pump was not turned over to Facility Operations as operating equipment, and it was to be used for prototype testing so as to demonstrate the mixing concept. Its operation was controlled from the DACS trailer by test engineers reporting to Plant Engineering. Both Facility Operations and Plant Engineering are part of Waste Tank Operations (see Appendix C). The test engineers operated the pump according to test procedures.

To keep the nozzles of the pump from clogging with tank contents, the pump must be run twice daily for about five minutes. This is called a "pump bump." The pump bump is performed in accordance with a test procedure*. This procedure requires Operations to take readings on waste tank instrumentation in the tank farms prior to each pump operation. These readings are referred to as pump bump rounds, and they are taken by shift operators.

Operations had assigned one shift supervisor to be the pump "expert." This person was involved in many aspects of the testing, and also approved some of the changes to the ATP. This individual also had assembled information packages (including drawings and photographs) to assist others. The packages were efficiently assembled, but they were used as an informal tool and not as a controlled document. The expert kept shift personnel informed through the use of information letters. However, there was no formal control over these letters to assure all personnel read and understood the information. No file was

*WHC-SD-WM-TPI-007, Revision 0, Pump Bump For Tank 101-SY

Mitigation-by-Mixing Test, dated July 26, 1993. 
established for these letters for use as reference material. The assigned "expert" performed these duties in addition to other normally assigned duties as a shift supervisor. This meant that the expert was not always available on the dayshift to provide Operations representation for planning and Test Review Group (TRG) meetings. The TRG is responsible for test monitoring, approval, and evaluation report review. This expert was not the shift supervisor who was on duty at the time of the occurrence.

There was no evidence of formal training of the shift supervisors or operations personnel on the test procedures for the 241-SY-101 pump operation.

The shift supervisors had different levels of understanding of the basic elements of the test procedures, the potential impact of the tests on the waste tank facility, or how operational actions could affect the test. Only the "expert" shift supervisor was knowledgeable of all aspects of the test. Based on interviews, the shift supervisors treated the testing as an area that was isolated from the operating facility by specific boundaries. It was perceived that, within those boundaries, any and all testing could occur without impact on the waste tank facility.

Interviews indicated that one shift supervisor had closed the pump disconnect switch twice prior to the incident, before becoming curious about the potential impact of such an action could have. This shift supervisor took the initiative to talk with the DACS personnel about the system. After the talk, the shift supervisor understood the implications of the disconnect switch operations. Another shift supervisor had the same curiosity, but asked DACS personnel for more information prior to directing the closure of the disconnect switch the first time. The Operations Shift Supervisor involved in this event closed the disconnect switch several times during the week prior to the event, while the crew was on the graveyard shift. At no time did the supervisor pursue the impacts with DACS personnel.

The Operations Shift Supervisor, who authorized the closure of the disconnect switch on August 4, 1993, had been on the graveyard shift the week before and was returning to work after having been off four consecutive days. On that graveyard shift, the routine had been to close the disconnect switch, if it was open, while doing the rounds. This was the only pump bumping experience the Operations Shift Supervisor had prior to the event on August 4, 1993.

Contacts between DACS test engineers and Operations were made twice a day, when the Test Director was required (by step 11.2.7 of the pump bump procedure) to obtain data within four hours of starting the pump. The puipose of the contacts was to coordinate activities for obtaining required data. The status of the testing activities was not always communicated during these contacts, and it appears that the contacts were an ineffective substitute for the specific briefing called for by the Standing Operating Instruction (SOI).

Based on interviews, it is clear that Operations management felt a great deal of ownership for the pump, the 241-SY-101 tank, and the waste tank facility. The senior operations 
TYPE B INVESTIGATION REPORT FOR 241-SY-101 PUMP START AND 241-C-106 PIT CLEANOUT

Figure 3. 241-SY-101 Overhead.

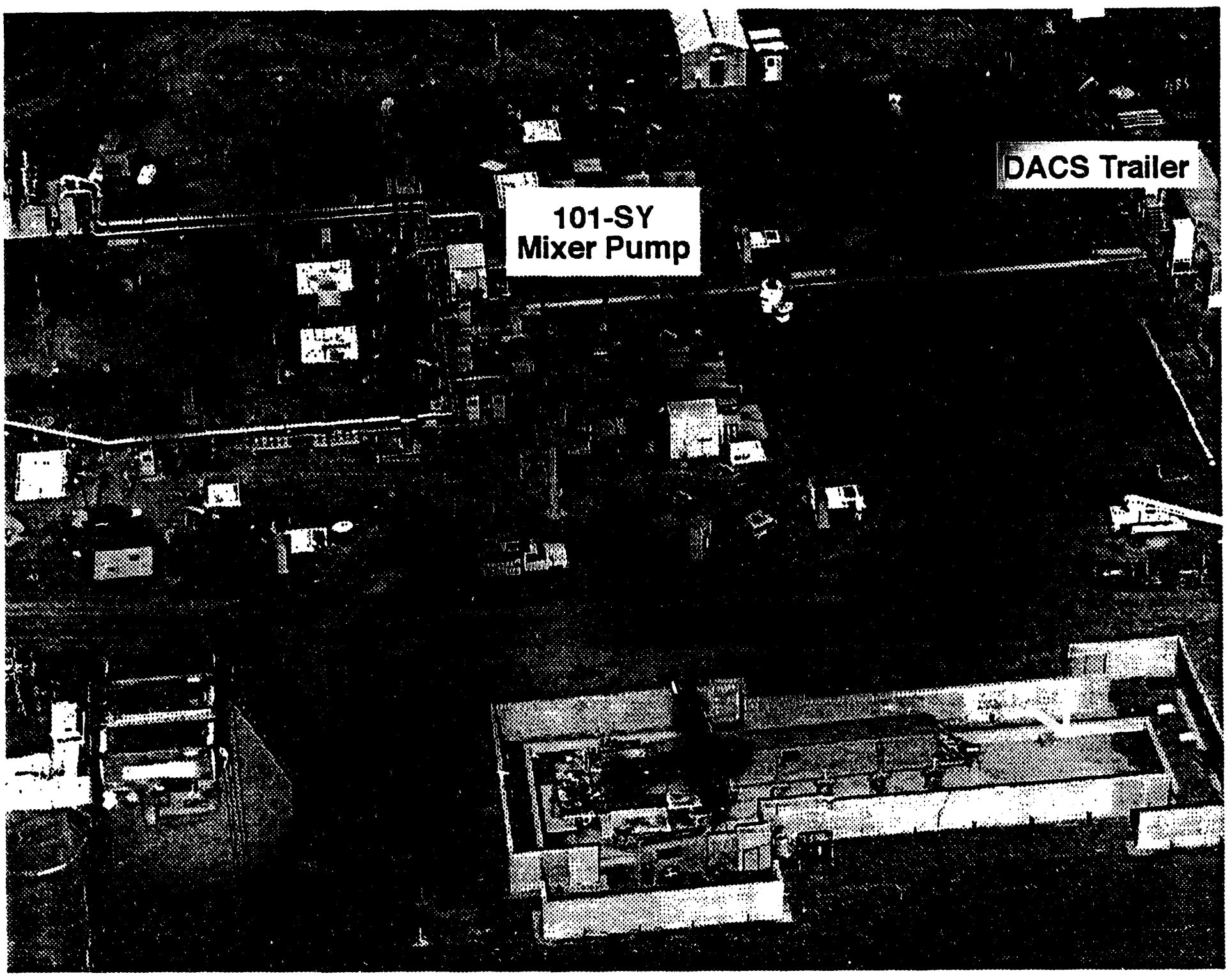


TYPE B INVESTIGATION REPORT FOR 241-SY-101 PUMP START AND 241-C-106 PIT CLEANOUT

Figure 4. 241-SY-101 Cross-section of Mitigation Mixer Pump.

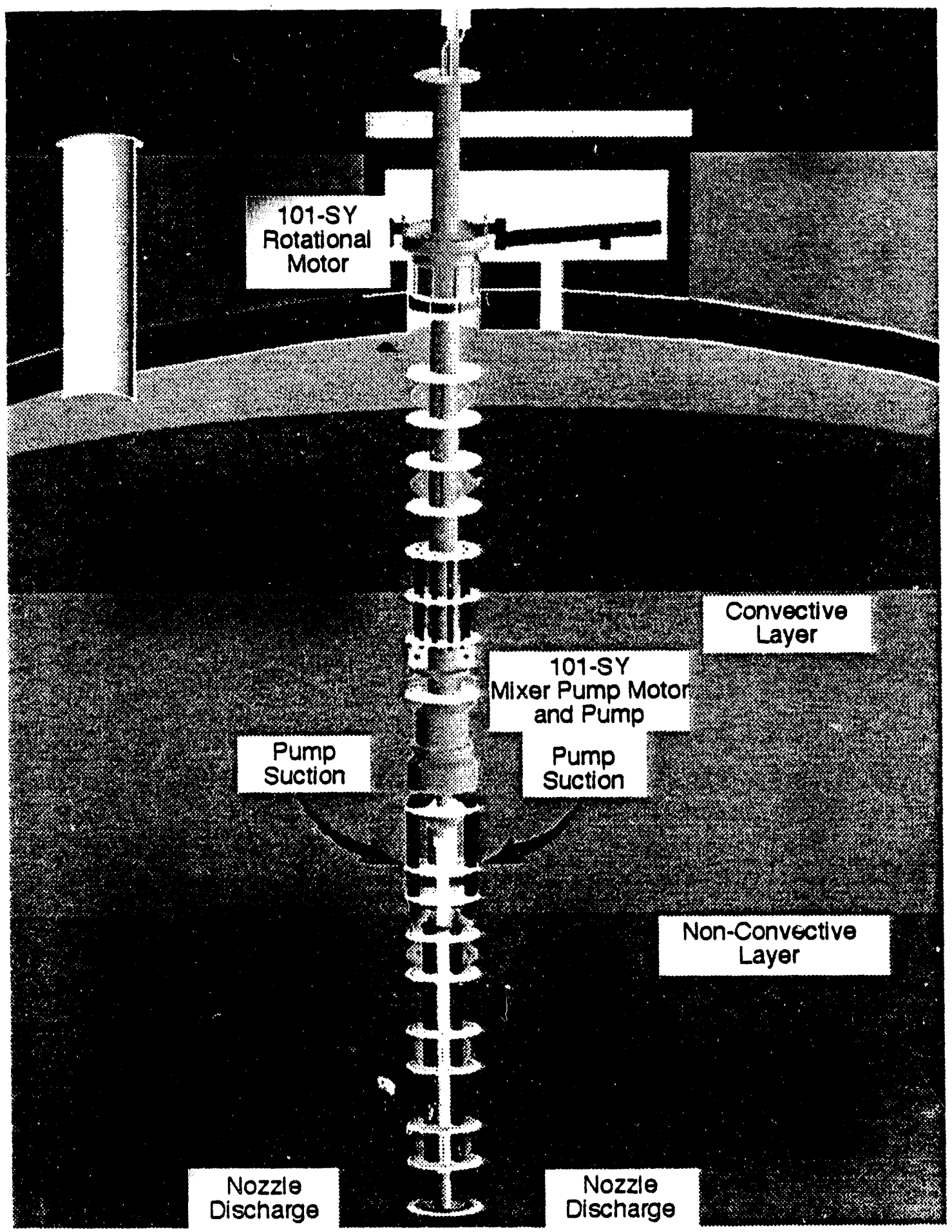


management, in particular, felt a high degree of ownership. Lower levels of management had a strong overall sense of ownership, but personnel involved with practical applications did not always reflect this sense of ownership. Shift management faced many demands for their time; consequently, the ATP became only a portion of their daily activities. They therefore acted more in a "support" role for ATP testing rather than in a "control" role. For example, the pump nozzle unplugging procedure* is consistent with this support role in that it formally assigns the Test Director as the person who is di-ecting operator actions during the execution of the procedure.

SOI 92-47 (Interface Understandings - Facility Operations and 101-SY Test Engineers) had been issued in October 1992, and specified the requirements for communications between Operations and Test Engineering. SOIs are used to provide long-term direction to shift personnel in completing goals and milestones. A SOI does not provide procedural direction. This SOI was signed by both Test Engineering and Facility Operations. The SOI required the DACS personnel to contact the Operations Shift Supervisor at the start of the shift, so as to communicate the status of the testing. This had been done for a period of time. But, during the months of October through June, activities associated with the mixer pump had been essentially limited to activities in the DACS trailer that had no operational impact on the mixer pump. Following the pump installation, due to the lack of operational activity, contacts between Test Engineering personnel and Operations become less formal and were done on a less frequent basis. When it became necessary to "bump the pump" to prevent plugging, contacts between DACS and Operations personnel had to be made twice a day so that the rounds required for pump bumping could be coordinated between the two groups. These contacts usually occurred at approximately 0400 hours, when DACS personnel arrived on site, and late (after 1400) dayshift (approximately two hours prior to the pump bump) on the swing shift. The status of the acceptance testing was not always provided to operations personnel during these communications. Furthermore, DACS personnel seldom provided the status of the acceptance testing to dayshift operations personnel at any time during their shift.

The routine closure of the disconnect switch on the graveyard shift did not ordinarily pose any hazard, since the computer was down and acceptance testing was not in progress. The basis for the 0400 arrival of DACS personnel was to get the required pump bump completed so normal acceptance testing could be started promptly on the dayshift. Conditions on August 4, 1993, were different because the computer was operating.

The basis for exclusion zone changed from excluding $r$, rsonnel from the tank farm during operation to a 300 meter radius zone, based on the ar jysis of the potential ammonia hazard. Further analysis allowed variation from a strict $3 a$, neter radius to one that incorporated factors such as wind direction and velocity. On July 26, 1993, a decision was made by a shift supervisor knowledgeable of the variations to allow personnel to remain within the

*WHC-SD-WM-TPI-008, Unplugging 101-SY Mixer Pump Nozzles, revision 0, dated July $25,1993$. 
radius exclusion zone. To allow consistent application, the definition of the exclusion zone was subsequently clarified by management to be a 300 meter radius exclusion zone.

On August 4, 1993, the ATP involved closing the main supply breaker and testing the DACS ability to control the mixer pump variable speed coupling device. The disconnect switch was required to be open in order to prevent running the pump (see Figure 5).

The closure of the disconnect switch was not part of pump bump procedure. The ATP controlled the closure in order to assure that the supply breaker and disconnect switch were properly positioned to successfully perform the ATP. The pump bump procedure was independent of the ATP, although the bumping of the pump could not occur while the ATP was in progress.

The disconnect switch had a Operations caution tag installed. However, the caution tag was not specific to component position, and only directed personnel to "contact shift supervisor or test engineering" prior to operation of the disconnect switch. The disconnect switch had been tagged and untagged several times (sometimes with caution tags, other times with danger tags). The last tag, a caution tag, had been authorized and hung on July 11, 1993. The ATP did not contain instructions for tagging components.

\subsubsection{Event Description}

At approximately 0400 hours on August 4, 1993, DACS personnel arrived on site. They started the computer to allow two hours for stabilization. DACS personnel also contacted Operations in order to coordinate the required rounds prior to the pump bump. The rounds were required to be completed within four hours of starting the pump. Since the pump and disconnect switch are located in a radiological controlled area, operations would close the disconnect switch, if it were open, as a concurrent task with taking normal shift readings.

The mixer pump was successfully bumped by the graveyard shift personnel. Shift turnover was completed at 0730 hours. As a part of this turnover the dayshift Operations Shift Supervisor was made aware of the ATP to be performed on the dayshift. Logbooks and interviews indicated no formal communications occurred between the DACS trailer personnel and the dayshift Operations Shift Supervisor at the beginning of the dayshift.

At approximately 1445 hours the Operations Shift Supervisor and DACS trailer personnel had a discussion about a low nitrugen pressure condition on the column purge. This had been recorded by an operator during performance of surveillance rounds. During the discussion, the DACS engineer told the Operations Shift Supervisor that ATP testing was still ongoing. The Operations Shift Supervisor and Test Director discussed the timing for starting the rounds for the upcoming pump bump. The Operations Shift Supervisor told the DACS engineer that he would direct the rounds to begin to support the pump bump. 

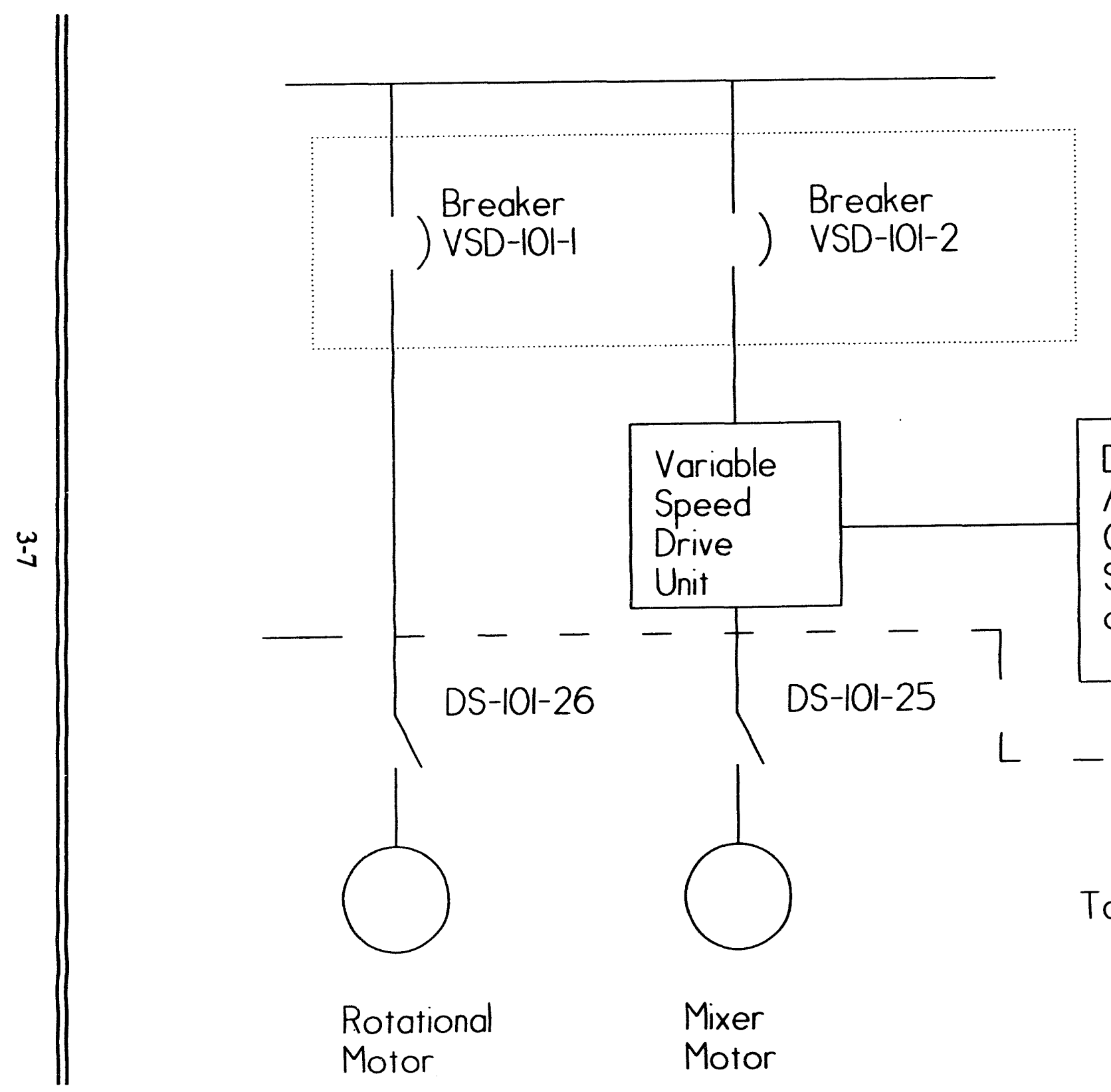

Motor

Control

Center

Rotational Motor

Mixer

Motor

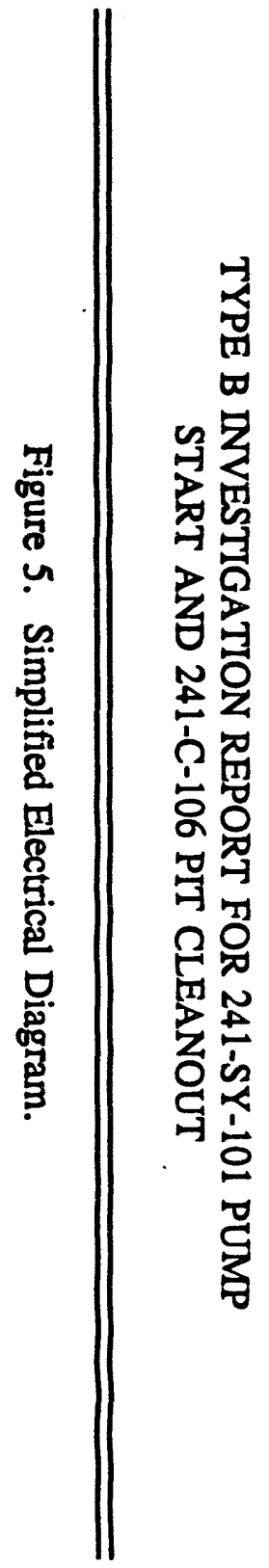


At about 1500 hours the Operations Shift Supervisor directed two operators to begin their rounds. One of the operators had taken readings previously, and was to walk the other operator through the rounds. The inexperienced operator had been temporarily assigned from the 200 east area facilities for the day shift. The operators dressed in the protective clothing that was required for tank farm entry. Just prior to entering the 241-SY Tank Farm, the more experienced operator reminded the Operations Shift Supervisor that the disconnect switch (DS-101-25) would need to be closed in order to perform the pump bump, and asked whether they should close the disconnect switch while performing the rounds. The Operations Shift Supervisor acknowledged that this would be required, and directed the operators to close the disconnect switch.

The operators entered the 241-SY Tank Farm and performed their rounds. When they reached the disconnect switch, they closed the disconnect switch (as they had been directed). But, without their knowledge, the mixer pump then started at 1515 hours. (The pump motor is located inside the tank.)

At 1515 hours DACS personnel were running an ATP on the pump software. They noticed, from the independent current monitor's positive readings, that the pump was running. DACS personnel immediately hit both the normal and emergency stop buttons, resulting in the shutdown of the pump. The mixer pump operated for approximately thirty seconds at maximum of $533 \mathrm{rpm}$ at 74 amps.

At 1522 hours DACS test personnel notified 242-S shift management that (1) the 241-SY-101 mitigation pump had been inadvertently started; (2) breakers VSD-101-1 and VSD-101-2 in the motor controller center had been returned to the off position; and (3) the pump had run for approximately 30 seconds.

The Operations Shift Supervisor, via radio, contacted the two operators who were in the 241-SY Tank Farm and requested that they call him on the telephone. He then called the Manager of Shift Operations, via telephone, to advise him of the inadvertent start of the 241-SY-101 mitigation mixer pump.

The two operators walked to the instrument building within the 241-SY Tank Farm and called the Operations Shift Supervisor, but the telephone line was busy, due to the Operations Shift Supervisor being engaged in discussion with the Manager of Shift Operations. The two operators then called Operations Shift Supervisor via the radio and requested that he call them at the instrument building within 241-SY Tank Farm.

The Operations Shift Supervis or called the two operators in 241-SY instrument building on the telephone and advised them that the mixer pump had started and they should "leave" the tank farm. He did not mention a DACS test engineer, nor any other personnel who might be within the tank farm. 
As the two operators proceeded toward the exit of the tank farm, they encountered a DACS test engineer. They advised the test engineer to exit the tank farm. The test engineer followed their advice after quickly reading a nearby instrument. (The test engineer had obtained Operations Shift Supervisor approval to enter the tank farm a short time prior to the occurrence of the inadvertent pump start.)

At 1530 hours all personnel exited the 241-SY Tank Farm.

At 1535 hours the Operations Shift Supervisor directed DACS test personnel to suspend ATP testing and pump bump preparations pending results of the investigation. The Operations Shift Manager proceeded to make other management notifications.

At 1555 hours the DACS computer printouts were evaluated, and there were no indications of a gas release. The hydrogen, nitrous oxide, and ammonia levels were normal.

At 1600 hours the Safety Assessment was reviewed by the DACS personnel for possible violations.

At 1609 an evaluation of the potential for damage to the pump or associated equipment was made. No damage was noted.

At 1625 hours the Assistant Tank Farms Facility Operations Manager classified the event as an off-normal occurrence in accordance with DOE Order 5000.3B.

At 1655 hours the 241-SY-101 Tank Farm was released for entry.

At 1745 hours the Operations Manager received approval from the Manager of Waste Tank Operations to proceed with the pump bump, but to continue with the suspension of the ATP. This approval had telephone concurrence from the TRG Chairman.

On August 5, 1993, at 0800 hours, a TRG meeting was held with the Chairman attending by telephone. At this meeting, the TRG determined that the presence of personnel within the 300 meter exclusion zone during the pump operation was a violation of a Level II criteria of the Safety Assessment, and would require a full TRG committee approval for resumption of pump bumps and ATPs. This approval was provided.

On August 6, 1993, at 1115 hours, the Occurrence Report was upgraded to an Unusual Occurrence. 


\subsection{CHRONOLOGY OF THE 241-C-106 PERSONNEL CONTAMINATION EVENT}

As a part of a planned waste tank upgrade program, preparations were made to decontaminate and paint the three pits on waste tank 241-C-106. Work began in the 241-C-106 "heel pit" (Figures 6 and 7). The actual decontamination work was to be performed without entry into the pit area. The pit cover blocks had been removed; temporary covers were placed over the pit; and a glovebox was installed over the area to be decontaminated. When the cover blocks were removed, it was discovered that approximately three inches of sludge and water were covering the floor of the pit. It was decided that, prior to starting decontamination of the pit, a drain path for the existing water as well as for decontamination waste water would have to be established. Neither the work package or the Radiological Work Permit (RWP) that had been written for decontamination of the pit had been revised to include this change in the work scope. The following is a chronology of the activities that resulted in the contamination of a $\mathrm{KEH}$ employee.

In May 1993, the As Low As Reasonably Achievable (ALARA) committee, WHC point of contact (POC), and the KEH Superintendent began development of the work plan and safety assessment for the tank pit decontamination and painting job. Radiological planning was based on prior knowledge of radiological conditions in other pits, and on the assumption that entry would not be necessary in the containment.

On July 7, 1993, work package 2E-93-00613K was issued to decontaminate and paint the 241-C-106 tank pits.

On July 30, 1993, RWP \#E-S-150 was approved for the "Removal of all existing equipment from the heel pit for decontamination and painting of inner pit walls and floors, including pit cover blocks."

On August 6, 1993, the pit cover blocks for the 241-C-106 heel pit were removed. Temporary covers were installed over the pit. Approximately three inches of sludge and water were discovered in the floor of the pit.

On August 6, 1993, a pre-manufactured glovebox was installed over the heel pit.

On August 9, 1993, a containment was installed over the cover blocks.

On August 10, 1993, at 0845 hours, a tailgate pre-job briefing was conducted by the WHC POC with the help of KEH foreman. Attending were a Health Physics Technician (HPT) and the KEH laborers who were later contaminated. Also attending were several KEH workers who were awaiting their own pre-job meeting. The two KEH laborers were instructed to enter the glovebox installed at the 241-C-106 heel pit and determine if a cover was installed over the pit drain. The POC also asked the laborers to look for an open riser. The laborers interpreted this to mean they should check to find an open flow path to the tank. 
Figure 6. 241-C-106 Overhead.

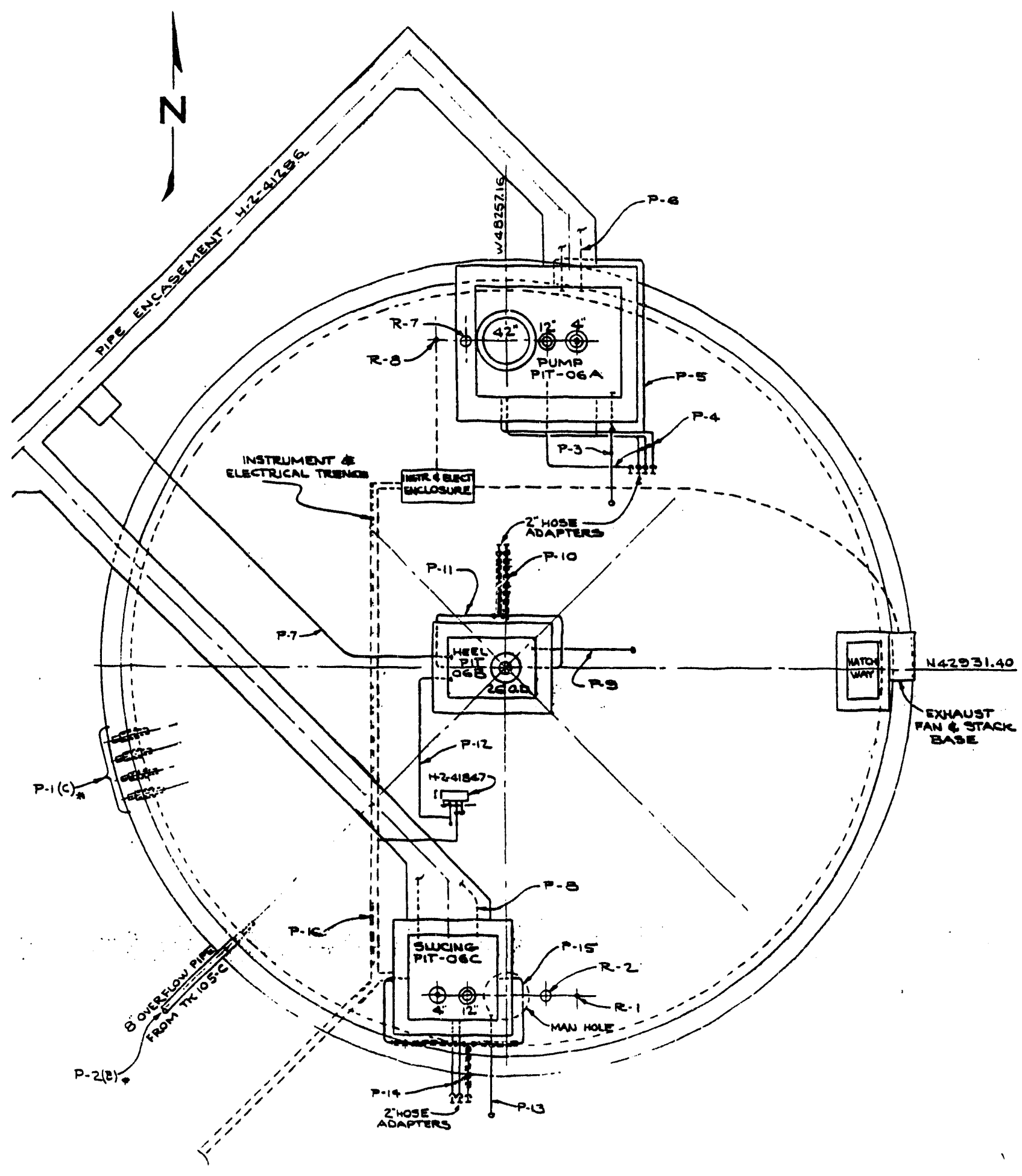


TYPE B INVESTIGATION REPORT FOR 241-SY-101 PUMP

START AND 241-C-106 PIT CLEANOUT

Figure 7. 241-C-106 Cutaway.

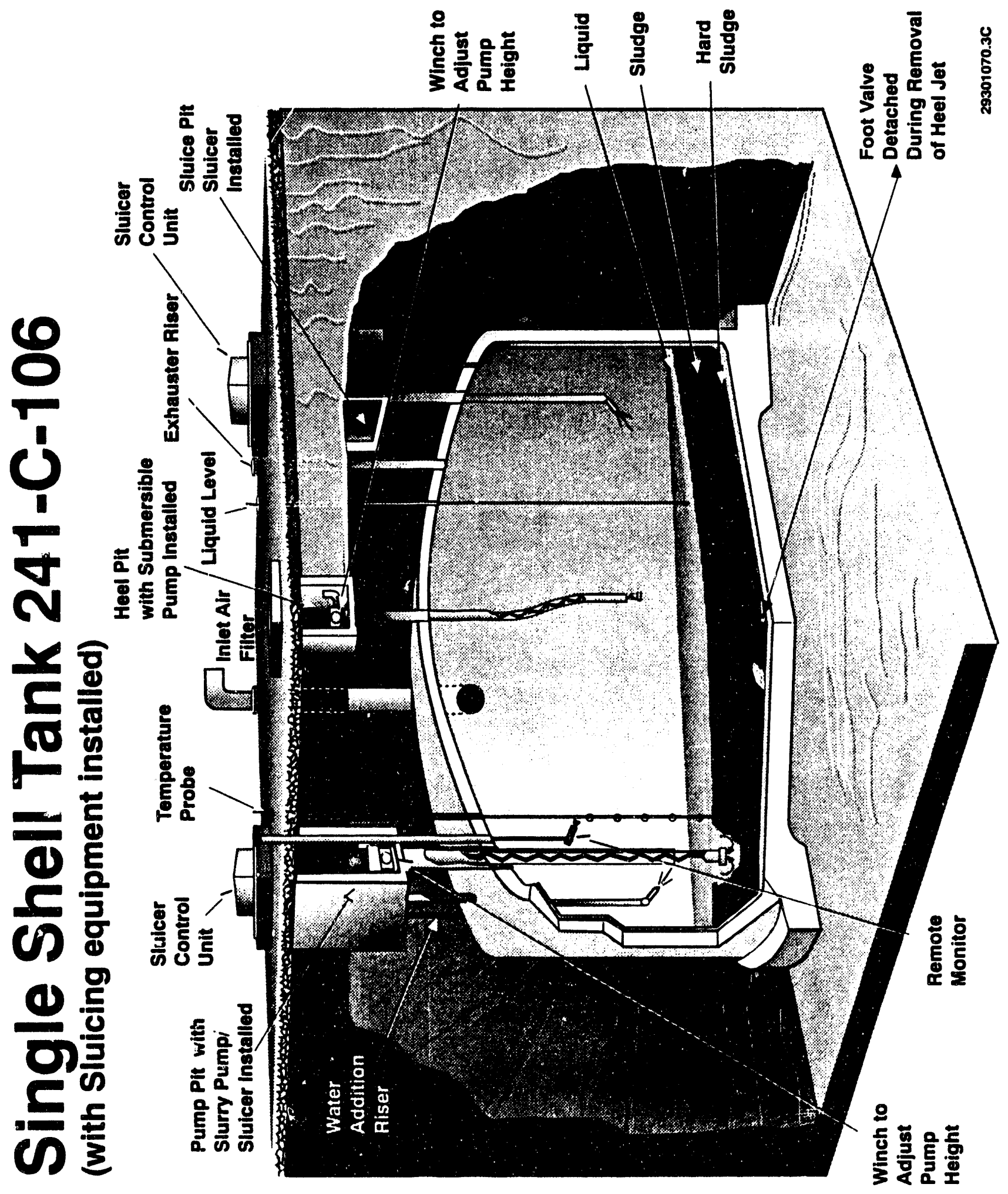


On August 10, 1993, at about 1000 hours, the two KEH laborers and the HPT, who had not participated in the pre-job briefing but had been briefed by the other HPT, entered the 241-C-106 heel pit glovebox. The HPT understood the job scope to be the same as that described by the POC. The HPT proceeded to perform a baseline radiation and contamination survey, while the two KEH laborers used a shovel to try to determine if a cover was installed over the drain.

On August 10, 1993, between 1000 and 1015 hours, the following events took place in the order given below.

- The two KEH laborers determined that the pit drain did not have a cover installed and was probably plugged.

- The HPT completed the baseline survey and left the glovebox to count the smears in a lower radiation background area.

- The two KEH laborers observed a 36 inch steel plate in the bottom of the pit, sticking above the water level, and decided to determine if one of the two open penetrations in the steel plate could be used as a possible drain path into the tank.

- A length (approximately 40 feet) of braided nylon cord was obtained. One of the $\mathrm{KEH}$ laborers taped a rock to it and it was lowered by the other KEH laborer approximately 25-28 feet into the larger of the two penetrations (Figure 8). When the cord went slack the KEH laborer assumed that this penetration was also "plugged," removed the cord and rock from the penetration, and left it lying on the temporary cover in the glovebox.

- The two KEH laborers exited the glovebox, passing the HPT as he reentered the glovebox to complete his survey. The KEH laborers proceeded to a step off pad to be monitored. The survey found the KEH laborers had high levels of contamination on their SWP clothing, up to $350,000 \mathrm{dpm}$ on their clothing and $23.5 \mathrm{mrad}$ on their gloves.

- The KEH laborers were wearing single sets of SWP clothing that were soaked through with perspiration due to the heat. One laborer had skin contamination levels of 2,000 dpm on his back and on the back of his arms.

At 1045 hours the HPT escorted the one contaminated KEH laborer to the decontamination room at 272-AW and decontaminated him.

On August 10, 1993, at 1430 hours an incomplete critique was held to review the event and identify any near-term actions to be taken. 
TYPE B INVESTIGATION REPORT FOR 241-SY-101 PUMP

START AND 241-C-106 PIT CLEANOUT

Figure 8. Heel Pit Penetration Cross-Section.

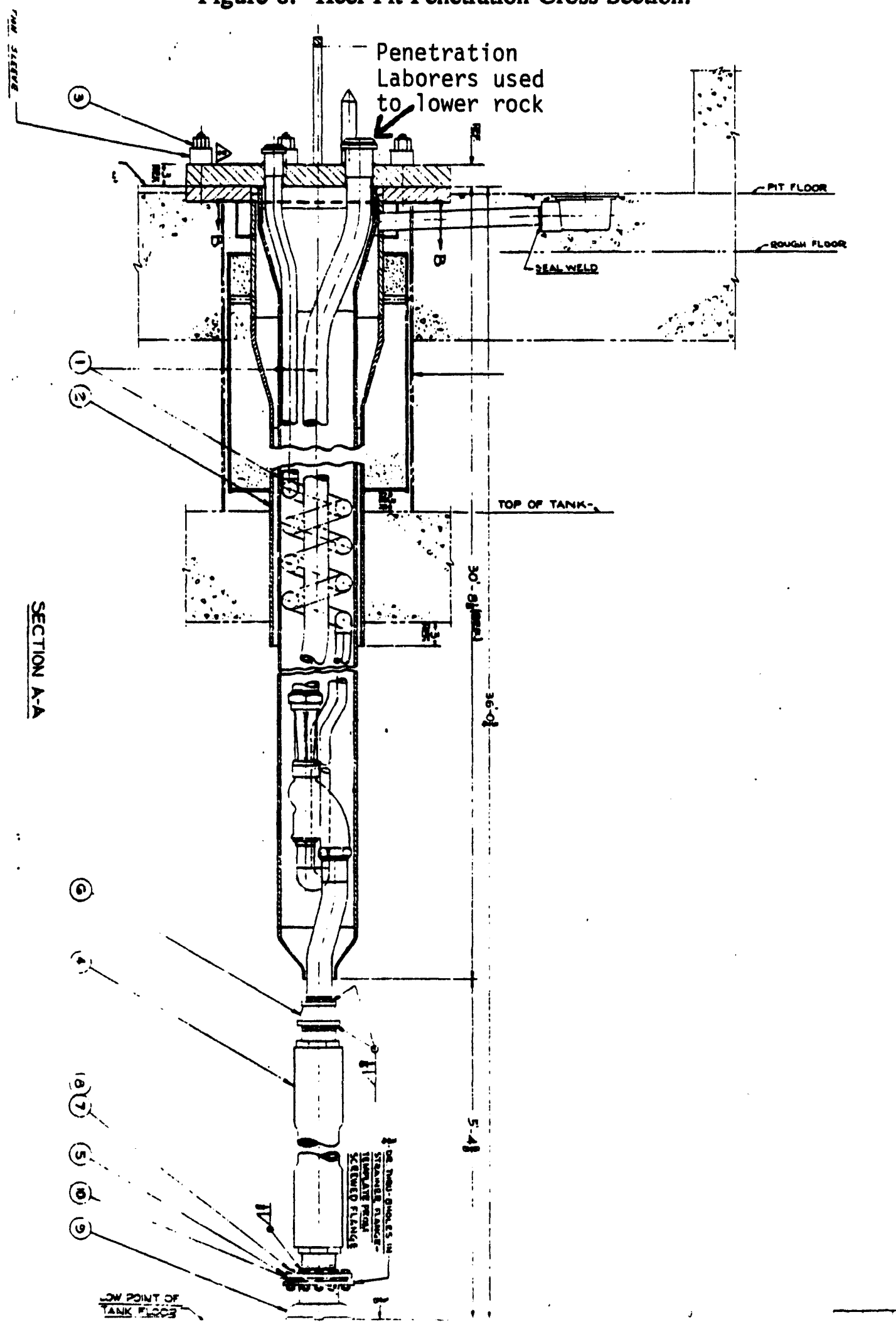




\subsection{GENERAL FACTS}

The investigation committee collected additional facts about the events through interviews with maintenance personnel, operators, health physics (HP), engineering, and managers. In addition to the two recent events, the Board reviewed other 1993 occurrences related to Tank Waste Remediation System (TWRS) operations. From this review the following groupings of related causal factors were identified.

- Conduct of operations/operational practices

- Safety/safety practices/safety awareness

- Management/management structure/communications

- Management processes/workprocesses

- Radiological practices/contamination/radiation awareness and sensitivity.

The Board used these five groupings, in addition to the specifics from the two events, to form the basis of its analysis.

\subsubsection{Conduct of Operations}

The purpose of Implementation of Conduct of Operations is to help assure the safety of the public, environment, facility personnel, and facility equipment. Conduct of Operations provides both the philosophy for implementation and the methods for performing operating activities. Rigorous adherence to the philosophy and strict compliance with the methods for performing operating activities are nece'ssary to minimize operating errors and improve overall performance.

Conduct of Operations at the Hanford Site Tank Farms is a requirement of DOE Order 5480.19, Conduct of Operations Requirements for DOE Facilities. The program is defined in three documents: (1) the Westinghouse GOCO Conduct of Operations manual; (2) a locally prepared document which summarizes the DOE Order; and (3) Section 5.0 of the Waste Tank Administration Manual (WHC-IP-0842). Section 5.0 contains a variety of procedures that delineate requirements for performing operating activities and reflect the requirements of both the DOE Order and the Westinghouse GOCO manual containing the DOE order requirements. 
Conduct of Operations training for tank farm personnel is based on the Westinghouse GOCO Conduct of Operations manual. Most operators, supervisors, and operations management personnel have received the training. Interviews with operators and supervisors have indicated that the Westinghouse GOCO manual is generally used, and that few operators are aware of the contents of Section 5.0 of the Waste Tank Administration Manual.

The eighteen chapters of DOE Order 5480.19, Conduct of Operations, were used to perform an analysis of Tank Farm operating practices and philosophies. Noteworthy facts are noted below, along with specific discussion where poor practices contributed to the two events.

\section{Chapter 1: Operations Organization and Administration}

The management oversight and facility monitoring programs established by procedures 5.1.1 (Management Surveillance) and 5.1.2 (Facility Manager's Surveillance) of the Waste Tank Administration Manual have had only limited success. Interviews with the coordinator of these programs identified that less than $40 \%$ of the scheduled tours were completed. The checklist and observation criterion contained in the procedures are predominately housekeeping and safety oriented, and very little attention is paid to Conduct of Operations. The personnel making the tours are not specifically trained in observation techniques, and they do not have any specific Conduct of Operations training for managers.

Operators and supervisors are routinely "encouraged" to make-do with unacceptable conditions and equipment deficiencies, such as little to no lighting in the tank farms, inoperative exhausters and level indicators, radioactive contamination on roads and walkways, inadequate foul weather apparel, inadequate office space, and a variety of additional unacceptable conditions.

The frequency of meetings between management and workers is minimal, and is generally the result of a reportable event or personnel injury. Planned focus sessions to identify and correct problems and unacceptable conditions are not normally held.

A fifth rotating operations shift had been approved but not implemented. The fifth shift was intended to provide dedicated training time.

Observations of the various shift managers offices and operator "ready" rooms identified a generally cluttered work environment that included the toleration of extraneous reading material (newspapers and magazines) and playing cards.

\section{Chapter 2: Shift Routines and Operating Practices}

While nominally responsible for facility operations, the shift manager's authority in the tank farm facilities has been degraded by the presence of various facility managers and operators on day shift. These individuals do not work for the shift manager but perform a variety of "operating" activities in the tank farms. 
There was no operator involvement in the planning and implementation of the 241-C-106 work plan.

While interviewing a shift manager in the shift manager's office, it was observed that the shift manager received phone calls and instructions from three different managers; only one of these was his immediate supervisor.

\section{Chapter 3: Control Area Activities}

The control area for the 241-SY-101 mixer pump is located in a structure separate from the shift manager's office. There is no required "tour" routine for areas such as this one.

\section{Chapter 4: Communications}

There is no public address system in any of the tank farms.

Pre-job briefings, although required for most work activities, are somewhat informal and do not use the checklist provided for this purpose.

\section{Chapter 6: Investigation of Abnormal Events}

Less than half of the occurrences reported in 1992 and those reported to date have had final reports submitted. Event investigation is conducted by dedicated event investigators, not by line management. Line management involvement appears to be minimal. The critique for the 241-C-106 event was terminated before it was completed, and was never restarted. Further investigation was initiated but was halted when it was learned that a Type "B" investigation was to be conducted. Written statements were not obtained from the WHC POC or the KEH supervisors or laborers. Some individuals felt the critique meeting minutes did not reflect all of the pertinent discussion at the critique.

\section{Chapter 8: Control of Equipment and System Status}

There is no program to red-line facility-essential drawings in order to document modifications. Essential drawings are updated by ECN incorporation within 30 days of work completion.

The 241-SY-101 mixing pump breakers were not under the control of the Shift Manager.

\section{Chapter 9: Lockout and Tagouts}

The disconnect switch for the 241-SY-101 mixer pump had been tagged with an "Information" tag that required the operator to contact the Shift Manager prior to closing the disconnect. No mechanical means to prevent closure (such as a padlock) were used. 
Chapter 10: Independent Verification

In the case of the 241-SY-101 mixer pump, the closure of the disconnect was not the result of the verification of the pump breaker status and was not procedurally controlled. In the case of the 241-C-106 personnel contamination event, there was no requirement for and no attempt made to identify or verify which riser the worker was trying to verify as being unplugged.

\section{Chapter 11: Log Keeping}

Interviews with "day" operators identified that, although they maintain logs, the logs are not considered "formal or official" and therefore are not reviewed by shift personnel.

\section{Chapter 12: Operations Turnover}

The operations turnover process does not include a briefing between operators and support organizations such as Maintenance, Health Physics, or Test Engineering. Additionally, the "day" operators do not attend a briefing and are not made aware of the tank farm status.

\section{Chapter 13: Operations Aspects of Facility Chemistry and Unique Processes}

The requirement for 3300 meter exclusion area when operating the 241-SY-101 mixer pump is not well understood by WHC personnel, and had not been in effect for very long.

\section{Chapter 14: Required Reading}

The required reading binder for operators is approximately two inches thick. One document is 200 pages in length.

\section{Chapter 15: Timely Orders to Operators}

The 200E and 200W Shift Managers' office contains binders for both "Shift Orders" and "Standing Orders." A brief review of these documents showed that they have not been maintained up to date, and the required shift supervisor and shift manager initials documenting the information were not current.

\section{Chapter 16: Operations Procedures}

The closure of the 241-SY-101 mixer pump disconnect was noi performed in accordance with an approved procedure. Although an ATP was normally used to control the evolution, it was also not in use by the operators who closed the disconnect switch. ATPs, which are used to operate facility equipment, are not validated by qualified operators prior to use. In addition, specific responsibilities for the control of the 241-SY-101 mixer pump are not clear or well understood. 


\section{Chapter 17: Operator Aid Postings}

There are many signs and postings in both tank farms that do not appear to be controlled as operator aids. There is no evidence that this played a role in either event.

\section{Chapter 18: Equipment and Piping Labelling}

An equipment and piping labelling program is in progress at the tank farms. Most components are not labelled. Many are not identified on facility drawings.

\subsubsection{Safety}

The WHC Waste Tank Project has a safety program that is specified in WHC-IP-0842, Section 15.1, Rev. 0, (10/1/92) (WTP). The purpose of the program identified as follows:

"It is the objective of the Waste Tank Project (WTP) to conduct all activities in a manner that protects the safety and health of all employees and the public and to prevent loss or damage to company operated facilities. All activities will be conducted in compliance with applicable health and safery requirements of the U.S. Department of Energy (DOE), and the Westinghouse Hanford Company, and with adherence to generally recognized and accepted high standards in the areas of occupational health, nuclear, radiological, industrial, fire safety, and environmental protection."

The waste tank project (WTP) Safety Program is established to provide guidance and direction to all WTP personnel on how to maximize the following safety elements:

- The safety knowledge of each employee

- The use of safety skills

- The safety performance of each employee

- The national reputation of Hanford Operations for safety achievement.

The KEH President has issued all employees a card. The card summarizes the essence of the $\mathrm{KEH}$ safety program. The text of the card is as follows:

We can always restart work - we cannot eliminate an accident after it has happened!

1. You are responsible for your own safety - don't do anything you believe to be unsafe (even if directed to do so) until you are satisfied it is safe. 
2. You have a responsibility for your co-workers' safety - don't let them do anything unsafe. You have "Stop Work Authority," and I expect you to use it whenever you see something you believe to be unsafe.

3. I expect management to help you perform these safety responsibilities. If you have a problem call me at 6-1738.

The safety program is established in the following documents:

- Waste Tank Administration Manual, WHC-IP-0842, Section 1.5

- WHC-CM-4-3, Industrial Safety

- WHC-CM-4-30, Nuclear Safety Manual

- Westinghouse Conduct of Operations Manual (implementing DOE-5480.19) July 1990.

Tank Farm safety conditions were reviewed to gain an understanding of personnel safety philosophies and sensitivities. Specific facts about the safety environment are given below.

Lack of lights at the C Tank Farm is perceived by Operations management and operators as causing danger to operators during night rounds. Other tank farms also suffer from lack of lighting. The terrain on the tank farms is not even. No well defined walkways exist. Personnel are suited up in protective clothing and often wear Self Contained Breathing Apparatus (SCBA) or fresh air breathing apparatus that limits vision. These problems are compounded by winter snow and cold conditions. Poor lighting conditions have existed for several years, and no effort has been successful in correcting this problem.

Ventilation systems are considered primary safety systems, since the principle of containment of radioactivity and radioactive contamination relies on higher negative pressure in more contaminated areas. Tank exhausters are used for ventilating buildings and tanks, and they serve as leak detectors in double-shelled tanks. Some exhausters have failed as a result of age or lack of maintenance; several exhausters were observed to be out of service during the investigation.

Tank level indicators are safety systems that provide information on tank contents. Some of the level indicating instruments are inoperable and have been replaced by "temporary" level detectors called "zip cords." Better and more permanent fixes are under consideration, but have not been implemented in most cases.

Loose equipment and debris are spread throughout the tank farm areas. Many concerns have been expressed about tripping hazards on the farms, and this is further emphasized when equipment is allowed to accumulate. 
Managers were asked what safety topics were discussed at their workplace meetings with employees. They responded that they reviewed daily accident reports. Managers knew how many people in their area had been injured, but were unaware of Total Recordable Cases (TRC) goals or year-to-date statistics.

Tank Farms operations management has recently been augmented by the addition of 25 newly trained managers and supervisors. These personnel have completed about six months of training. The new operations shift managers said that this training did not include specific orientation on accident prevention or OSHA awareness. The managers did not receive any training in such topics as the following:

- The supervisor's role in safety

- The means of ensuring a safe work ethic on a day to day basis

- The necessity for continued stressing of safety, statistics, and the need for safety improvement.

HPTs expressed concern that stopping a job required effort and considerable explanation. For all KEH work, a white card is generated to document the reason for job stoppage and loss of productivity. White cards are viewed by HPTs as "traffic tickets."

Interviewed $\mathrm{KEH}$ personnel expressed the need to be productive, since they believe nonproductive workers are not always given an opportunity to go to the next job. HPTs stated that KEH personnel brought their safety issues to the HPTs rather than to the KEH supervisors.

Operations and radiological control personnel have routine meetings with direct management where safety concerns may be discussed. There are a few routine meetings with level 1,2 , or 3 managers where employees may communicate concerns with higher-level management.

\subsubsection{Management Organization}

Field work at the Tank Farms is performed by several organizations. Key organizations involved in the two events include WHC Waste Tank Operations, WHC Health Physics, and $\mathrm{KEH}$ construction services (detailed organization charts are included in Appendix C). Numerous other organizations provide support (e.g., procedures, uraining, engineering, industrial safety or quality assurance) or play lead roles in specific facilities (e.g., Low Level Waste Disposal--i.e., the Grout Facility). The support organizations were not reviewed since they did not play a major role in the two events. 
WHC Waste Tank Operations reports to a level 2 manager and primarily consists of Facility Operations, Plant Engineering, Waste Tank Production Control, and Waste Tank Maintenance. Each of these functions reports to a level 3 manager. Facility Operations is further divided into Shift Operations, East Facilities, and West Facilities. A small Conduct of Operations organization is provided in Facility Operations to coordinate Conduct of Operations upgrades. The Shift Operations organization is responsible for routine operations and surveillance in both the East and West Tank Farms. Supervisors in Shift Operations are level 6 managers. The East and West Facilities organizations are divided into groups focusing on specific activities (e.g., core sampling) or specific plant areas (e.g., 242-A Evaporator or AP/AN/C Complex). First-line managers in the East and West Facilities are level 5 managers.

The Plant Engineering organization within Waste Tank Operations provides test engineering, systems engineering, data acquisition/computer support, and shift engineering support for Operations. These activities are organized by topic area (e.g., waste treatment, single shell tanks, double shell tanks, computers, shift work, tests) rather than by plant area. First-line managers in Plant Engineering are levels 4 and 5.

The Waste Tank Production Control organization within Waste Tank Operations provides planning, scheduling, job control system administration, and parts/materials collection for maintenance work. The Planning and Materials services organizations are split into east and west plant area groups, while the other functions serve all of the tank farms. First-line managers in Waste Tank Production Control are levels 4 and 5.

The Waste Tank Maintenance organization within Waste Tank Operations provides maintenance engineering services, craft maintenance, and major maintenance coordination with KEH. Maintenarice engineering is organized by engineering discipline (electrical, mechanical, instrumentation, etc.). Craft Maintenance is divided into nine groups; there are four groups for the East Tank Farms, four groups for the West Tank Farms, and one group of insulators and painters that serves all of the tank farms. Major maintenance coordination with $\mathrm{KEH}$ is divided into electrical and mechanical upgrades. First-line managers in Waste Tank Maintenance are level 5 managers.

WHC Tank Farm Health Physics reports through the Environmental, Safety, Health and Quality Assurance organization. Tank Farm Health Physics is organizationally independent of Waste Tank Operations. The Health Physics organization is responsible for providing radiological support to field jobs. Radiological work planning and ALARA determinations are made by the HP planning group and the Operations ALARA group. The Tank Farm Health Physics manager is a level 3 manager; first-line managers are level 5.

$\mathrm{KEH}$ provides architect engineering, project management, and construction services at the Hanford Site. KEH has four project divisions, an engineering division, and a construction services division, each headed by a manager. These major groups are subdivided and may in turn be subdivided into smaller groups, each led by a manager. KEH typically has no more 
than three levels of management below the President. KEH may be providing engineering or construction services and managing these services in the form of a project with a project management structure, or could be providing labor with craft supervisors (foremen) and superintendents.

When KEH manages a project, they may have sub-contractors or KEH construction forces working to contractor or $\mathrm{KEH}$ work packages with $\mathrm{KEH}$ quality control and quality assurance, with Health Physics coverage provided by WHC. $\mathrm{KEH}$ also provides workers and supervision for tank farm major maintenance work. Work packages are developed by WHC personnel, and are turned over to KEH for assembling materials and personnel who are completing job safety analyses and performing work. KEH comments on work packages are incorporated into work plans. KEH supervision directs KEH workers with a WHC POC assisting to coordinate various elements of the job, including Health Physics and Operations. KEH craft radiation workers are pulled from a large labor pool of union workers, and all have received radiological and safety awareness training for the Hanford Site.

In the case of the 241-C-106 incident, the KEH Construction Services Division, through the 200 Areas Construction Forces Group, provided the workers, their foreman, and the labor superintendent. They were to work to the WHC-developed work package and RWP, and were to be overviewed by the WHC Tank Farm Health Physics organization and a WHC point of contact. KEH work was initiated by a Letter of Instruction (LOI). Initially, KEH tasks were performed by the KEH superintendent and consisted of participation in development of the work plan and preparation of the Job Safety Analysis.

\subsubsection{Management Process}

3.3.4.1 Maintenance Process. The purpose of the maintenance process is to assure a well maintained facility with equipment and system in good operational order. The process also maintains instruments that are calibrated to assure accurate monitoring of systems within the facility.

The maintenance program is defined in multi-tier documents that establish and implement the policy. The program establishes the flow of process, the requirements for different types of work, the standards for work documents, the quality of the documents, and controls for the interfaces between organizations and programs. The documents below relate directly to the maintenance process. Many other documents in addition to these control various aspects of the maintenance process (such as procurement, environment, quality, safety, standards, other interfacing documents) and others deal with specific aspects (such as welding, operational procedures, splices, records retention) that support the maintenance process.

- WHC-CM-1-1, Management Policies, MP 5.3, "Job Control System" 
- WHC-CM-1-3, Management Requirements and Procedures

- MRP 3.3, "Records Management"

- MRP 4.7, "Turndown Work"

- MRP 5.43, "Impact Levels"

- MRP 6.11, "Job Control System."

- WHC-CM-8-8, Job Control System

- WHC-IP-0842, Waste Tank Administration Manual, Section 9.0, Maintenance and Production Management

- WHC-SP-0850, Maintenance Implementation Plan for Waste Tank Maintenance and Production Management.

The purpose of a maintenance work control system is to provide pre-planned, reviewed, and verified work packages that enable qualified personnel to perform quality work. The process is described in WHC-IP-0842, Section 9.5, Rev. 1: "Job Control System."

The Job Control System procedure defines several work control forms. These include the following:

- J-1 Work request -- primary work document

- J-2 Combined form used for impact level 4 work

- J-3 Pre-approved support request

- J-4 Resolution/re-test form

- J-6 Modification impact review

- J-7 Work change notice

- J-8 Work release sheet

- J-9 Partial release sheet.

There are several types of work packages. The most common of those in use are the J-1 Work Request, and the J-3 Pre-Approved Support Request. The J-1 is the more controlled document used for more complex, safety-related work. The J-1 package is made up of the $\mathrm{J}-1$ form plus other $\mathrm{J}$ documents and the supporting information. The J-3 is the simplest method of requesting work. It is intended to provide a means for accomplishing simple tasks without going through the formality of the other processes. The work must be on a list of pre-approved tasks, and does not require, but may utilize, formal scheduling tracking. 
Examples are chart recorder re-inking, equipment moves, oil additions, and relamping. The processes are illustrated in WHC-IP-0842, Section 9.5, Rev. 1. The J-3s are logged in and then sent to the appropriate craft manager as fill-in work. Some items are worked as priority items if there is a specific need expressed. Interviews with first line supervisors showed that they normally had about $100 \mathrm{~J}-3 \mathrm{~s}$ to be worked at any point in time. They also had no indication which of the J-3s were items related to safety, so they issued the J-3s on a first-in, first-out queue basis.

There has been an improvement within the last few months on the work-off rate of J-3s, because the criteria for the types of work allowed to be performed on $\mathrm{J}-3 \mathrm{~s}$ has become more commonly known. This has resulted in lower rejection rates for this type of work request.

Despite the stated level of activity, many operators felt nothing ever got done, or that it took "forever" to get anything done. The interviews support the operators' positions of the length of time required to respond to $\mathrm{J}-1 \mathrm{~s}$.

The more complex J-1 Work Request involves a pre-work review by maintenance personnel. The quoted time from interviews for a J-1 to transverse the system was from a few days to two years. Priority one work is hand carried through the process, and requires the least time. All other work usually requires a few months. Interviews disclosed that maintenance personnel are given insufficient time to review the packages. Following maintenance review, the package is returned to the preparer and then moves on to Planning and Scheduling, where it is released for work.

Interviews also disclosed that the evaluated work packages may not be given to Maintenance until the morning of the day that work is to be accomplished.

3.3.4.2 Test Control Process. The purpose of a test control program is to ensure that tests are planned and reviewed, and that prerequisites and coordination between operations, testing, and other organizations are identified. The control of testing is discussed in WHC-CM-6-1, Standard Engineering Practices, EP-4.2, "Testing Practices." The Waste Tank Administration Manual, WHC-IP-0842, Section 8.8, Functional Tests, and Section 8.10, Process Tests, discuss normal tests within tank farms. A special document, WHC-SD-WM-MA-014, Mitigation Test Management, was written to define the organizational responsibilities and relationships for the 241-SY-101 mixer pump tests.

3.3.4.3 Prioritization Process. A prioritization process assures that required actions are worked in an orderly, controlled manner. Safety, monetary factors, and levels of importance are factored into the decision process. The work priority system is described in WHC-IP-0842, Section 9.5 Rev. 1 ("Job Control System"). This document describes the 4 level priority system, where priority is are necessary to recover from unsafe conditions, reestablish the safety envelope, avoid imminent violation of safety requirements, or restore security systems. As the priority number increases from 1 toward 4 , the importance of the 
activity decreases. From discussions during the interviews, it appears that work/tasks are being identified as fast (or faster) than the activities are being accomplished.

\subsubsection{Radiological Practices}

The purpose of Radiological Protection Program is to protect the safety of the public, workers, and the environment from the radiological conditions at the Hanford Site. This includes the planning of evolutions to ensure that work performed under radiological conditions meets the requirements as outlined in the DOE Radiological Control Manual (DOE N5480.6;1992).

The DOE Radiological Control Manual requires that a site-specific manual be created for the Hanford Site. This program is established in the Hanford Site Radiological Control Manual (HSRCM-1). The WHC-CM-1-6 manual was written to reflect the HSRCM-1.

WHC-CM-1-6 replaced WHC-CM-4-10, which was the previous WHC radiological control manual. Individual WHC facility procedures were then revised to reflect the new requirements. KEH utilized HSRCM-1 as the requirements source from which lower-tier $\mathrm{KEH}$ implementing procedures were written.

Interviews with HPTs have indicated that, although the HPTs are aware of the new WHC-CM-1-6, they are not familiar with the new requirements introduced by this manual.

A review of the two events and the interviews with HP personnel, operators, planners, schedulers, and KEH construction forces personnel identified facts relating to the Hanford Site waste tank farm radiological practices.

3.3.5.1 RWP/Work Plan. The ALARA group's involvement with the RWP and work plan for the decontamination and painting of the 241-C Tank 106 pits, ended with the initial review. They were not aware of the need to enter the glovebox to complete work.

Mockup training was not performed for this job, even though high contamination and radiation levels were anticipated. KEH personnel were unfamiliar with the use of gloveboxes.

Personnel did not recognize that the scope of the job had changed when the water was discovered and the decision was made to enter into the glovebox.

Three separate RWPs with the same number were written to describe work in the heel pit, sluice pit, and the pump pit with identical radiological controls. 
3.3.5.2 Pre-job Briefing. There are requirements for pre-job safety briefings. These were completed for the KEH personnel on August 5 and 6, and addressed the overall decontamination and painting work scope. Only the safety aspects as identified in the Job Safety Analysis are discussed.

The Board could find no evidence of established requirements for pre-job briefings that discuss the full scope of the work (including safety and process aspects). An informal prejob briefing was held by the POC at the work site. The HPT was called away to cover another job during the briefing. The work scope was not clear to the HPT and workers. The HPT perceived the job scope was limited to the workers using a shovel to attempt to remove a possible drain cover or loosen sediment to unclog the drain, and to determine if there was an open riser. The workers perceived that they were also assigned the task of discovering a method of transferring water from the pit floor into the tank. No drawing or sketch was used to define work at the briefing. The inherent dangers of the tank were never discussed, and it was assumed that all the workers knew to limit actions involving possible contact with contents of the tank. The workers had previously observed operators using "zipcords" to take tank level measurements when the permanent indicators had failed. They also had observed routine dipping of bottles into various waste tanks for samples. Although routinely done, these activities have close HPT supervision and all items are sleeved by plastic as they are removed from the tank.

3.3.5.3 Radiological Coverage. A pre-job survey was not performed prior to entry into the glovebox by the workers. Interviews indicated personnel had many different understandings of the term "continuous coverage." Interviews indicate that KEH workers generally solicit advice and direction from HPTs on how best to meet radiological requirements. The interviewed KEH workers expressed a belief that they could not increase the amount of anticontamination clothing specified on the RWP.

Radiological Problem Reports (RPRs) are documents issued by all personnel to identify unsatisfactory radiological conditions. During interviews with HPTs, it was disclosed that the HPTs felt the RPR system was ineffective in corttrolling unsatisfactory radiological conditions. 
TYPE B INVESTIGATION REPORT FOR 241-SY-101 PUMP

START AND 241-C-106 PIT CLEANOUT

This page intentionally left blank. 


\subsection{ANALYSIS}

This section provides an analysis of the two events, along with key cultural factors and management processes that contributed to the events. The cultural factors and management processes discussed here include Conduct of Operations, Safety, management organization and communication, maintenance and test control processes, and radiological work practices. An analysis is made here of how weaknesses in these areas may have contributed to the cause and severity of the two subject events. As is the case in most investigations of this type, observations, interviews, and reviews of procedures and policies opened new lines of inquiry.

\subsection{1-SY-101 ANALYSIS}

An events and causal factors chart (Figure 9) was the primary analysis method, with barrier (and control) and change analysis also used to support the events and causal factors analysis. A number of barriers and controls should have prevented this event. Chief among these are communication, knowledge, and test controls.

Communication acts as a barrier to ensure personnel are aware of current test status. SOI 92-47 formalized communications between Operations and Test Engineering. In time SOI 92-47 (issued in October 1992) fell into disuse. Communication of test status and testing implications to other activities did not occur at the shift change. The opportunity to communicate this information during the discussion with DACS personnel just prior to the disconnect switch closure was missed.

Knowledge also represents a barrier to failure by providing an information base that can be used to make proper decisions. In this case operations did not have sufficient information to make proper decisions, as evidenced by the shift supervisor directing the closure of the disconnect switch. Knowledge of the test procedure contents could have made the shift supervisor aware of the potential for inadvertent pump starts. The shift supervisor had not been trained on the test procedure, and was not aware of the contents of the test procedure. The informal training failed to assure that all operations personnel received the training, nor was there a requirement that the personnel who did receive the training demonstrate adequate knowledge.

Definitive control of testing activities ensures that activities are coordinated. Two types of control can be established: physical and administrative. A lockout on the breakers and disconnect switches would have provided physical assurance of their positions. In this case a lockout on the disconnect would have provided a physical barrier. Additionally, verification of the desired position of the disconnect switch was not made prior to directing the switch to be closed. 


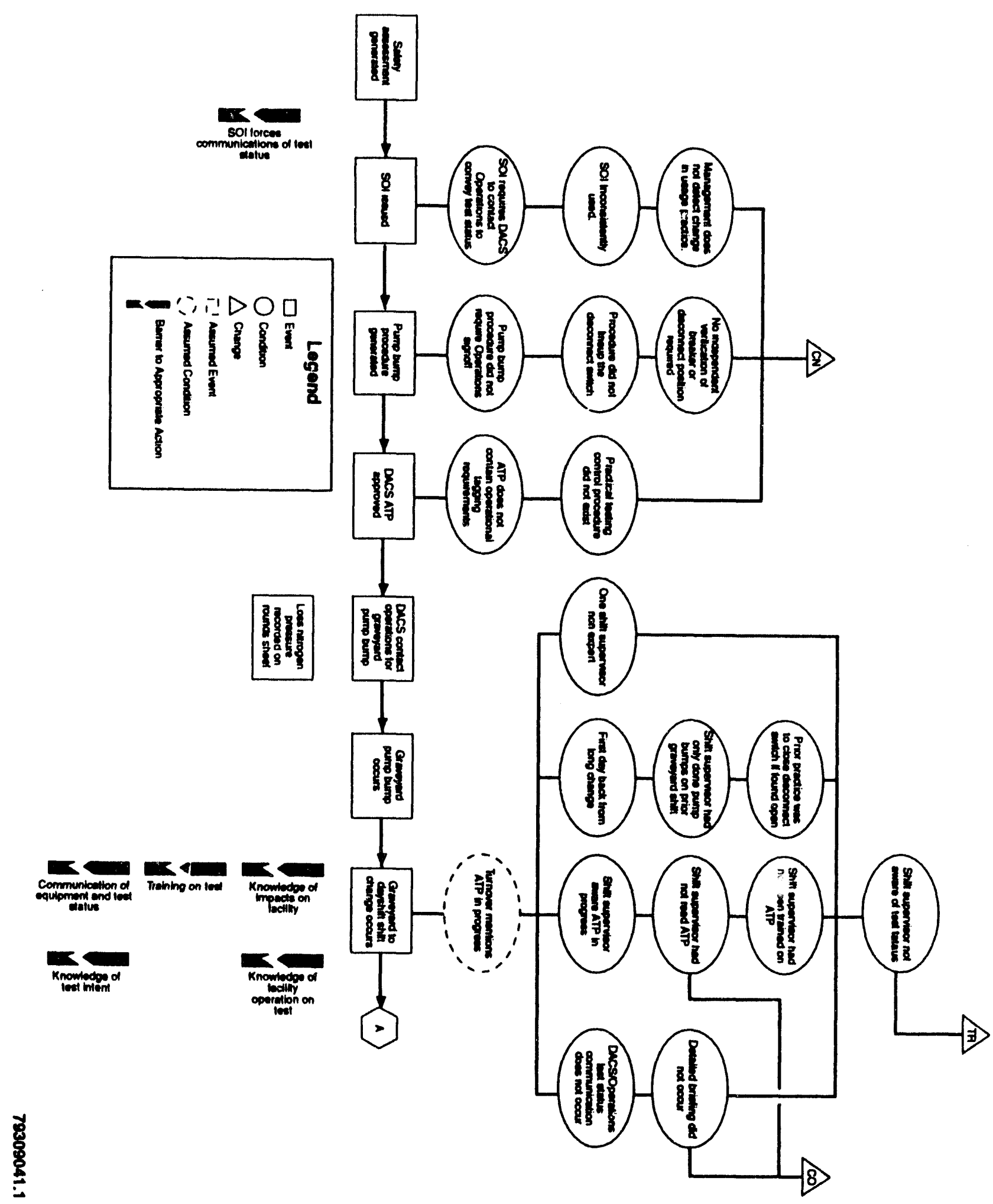

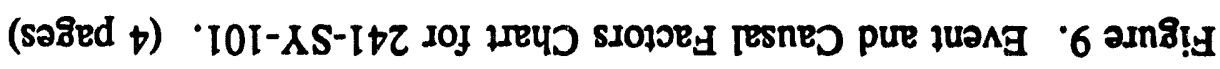




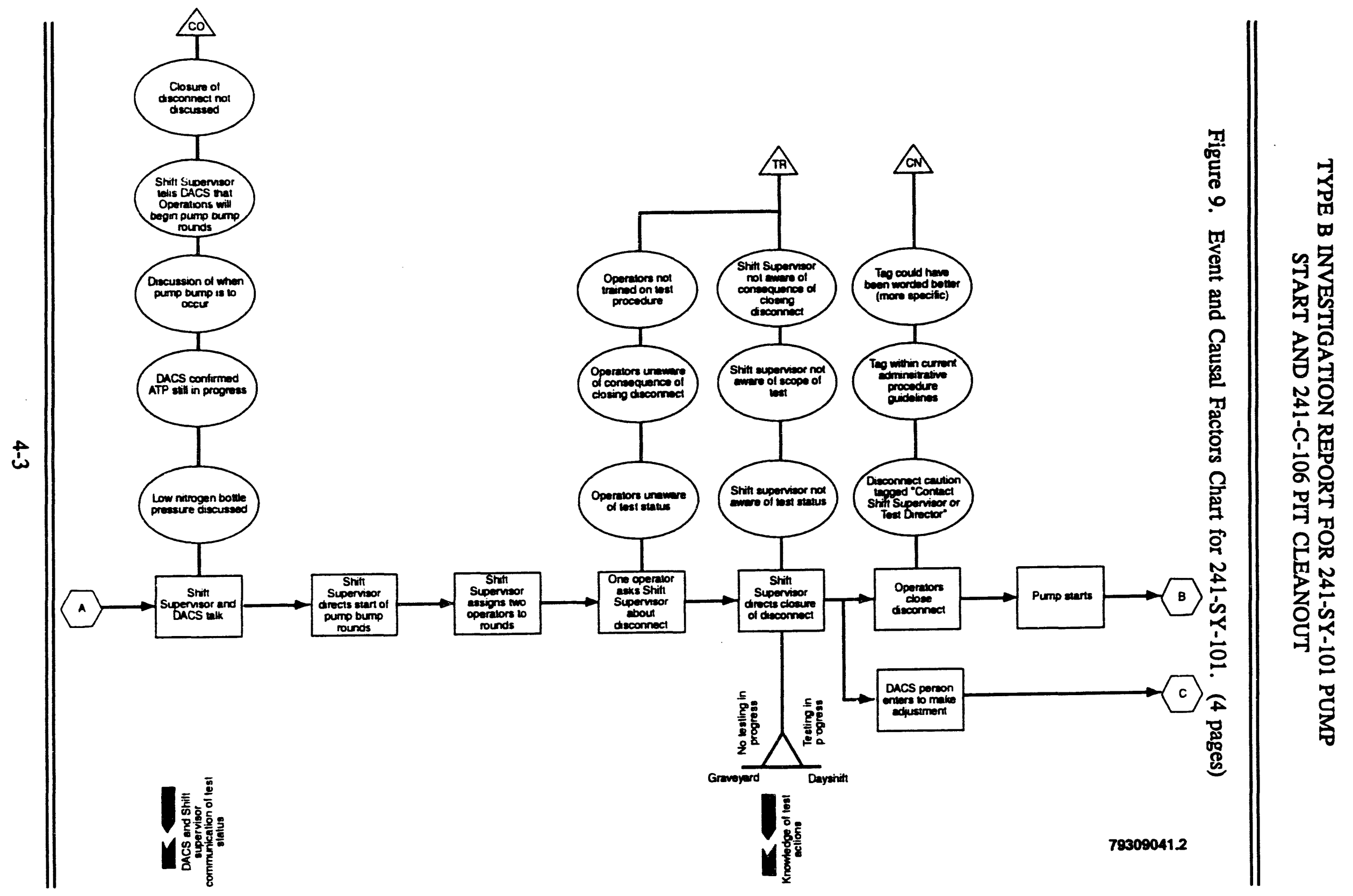




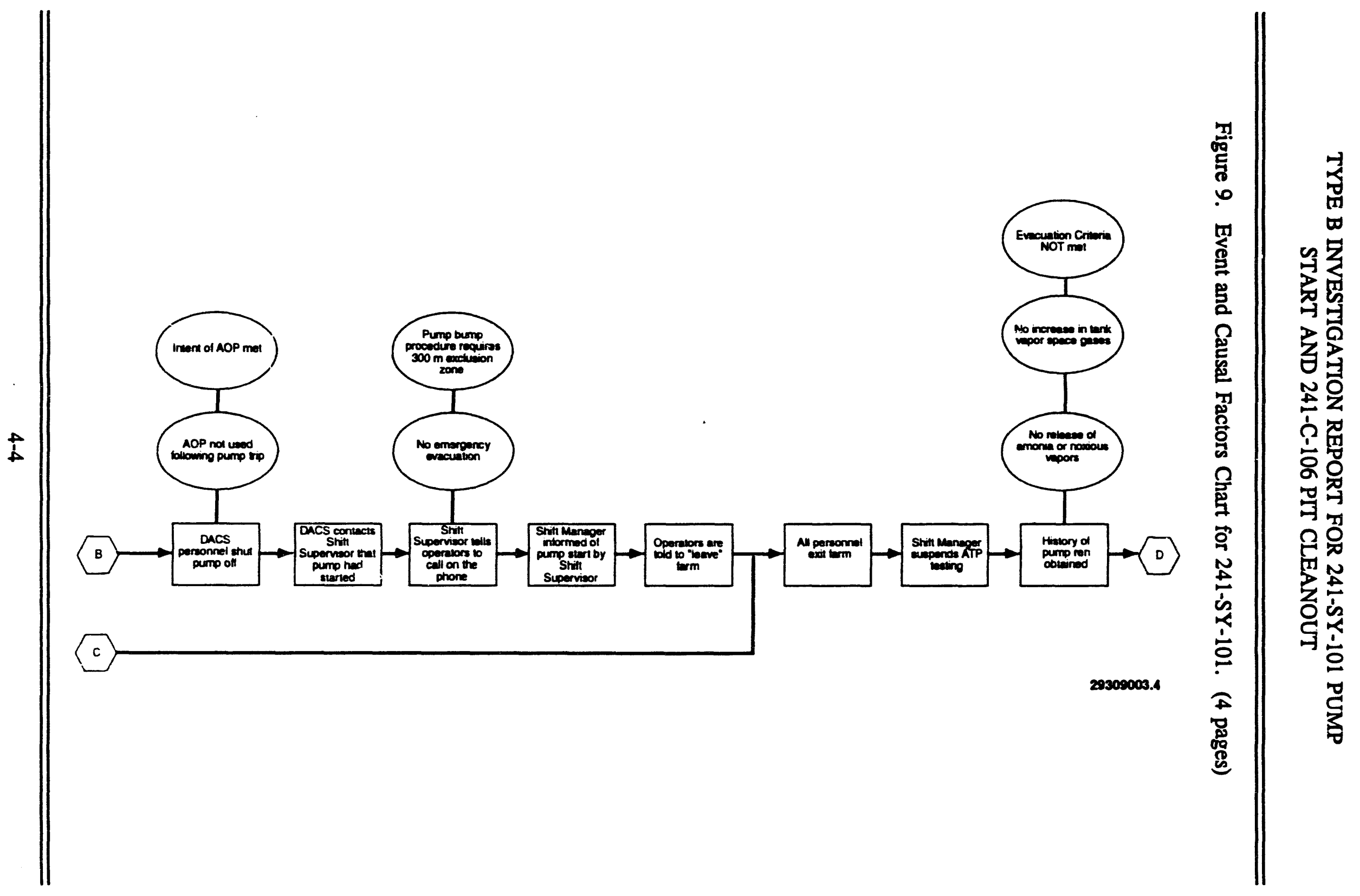


TYPE B INVESTIGATION REPORT FOR 241-SY-101 PUMP START AND 241-C-106 PIT CLEANOUT

Figure 9. Event and Causal Factors Chart for 241-SY-101. (4 pages)
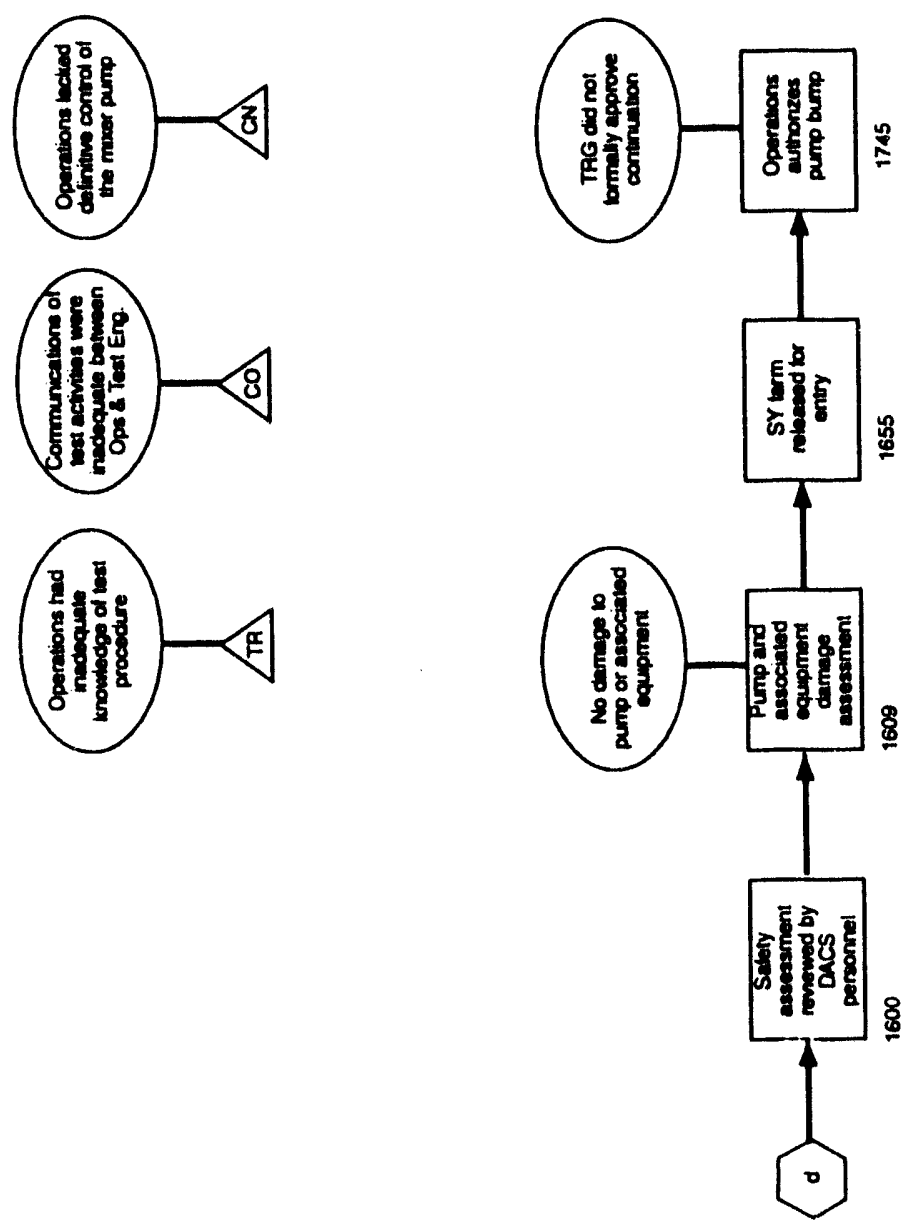
Effective administrative control was not established by the use of procedures, authorizations by Operations in the test procedures, or administrative instruction on the conduct of testing. Additionally, despite statements of Operations and established policy, Test Engineering was in charge of the testing and operation of the mixer pump; Operations was fulfilling a support function. While Operations management stated they "owned" the mixer pump, they did not detect that actual field practice was different. In summary, the change in the testing method and the need for increased control by Operations was not detected by management. Management had communicated their expectations, but was unaware that their expectations were only being partially met.

The board determined that there were three root causes to the inadvertent start of the 241-SY-101 mixer pump. The first root cause is that operations had inadequate knowledge of the mixer pump test procedures. The contributing causes to this root cause are described below.

\section{Training Less than Adequate}

Operations had not received formal training on the mixer pump test. One shift supervisor was the expert on the testing. This shift supervisor had provided informal training to other shift personnel, but because the training was informal there was no assurance all personnel received the training or had adequate knowledge of the testing. With the lack of knowledge of the test procedure the shift supervisor had insufficient information to make proper decisions.

\section{Unique Test}

The mixer pump is a prototype and, as such, is a unique component. The pump was never intended to be turned over to operations. Because of the limited time the pump was intended to be installed, the regular operator training was not updated to include this pump or its associated systems.

The second root cause of the event was inadequate communications of the planned test activities. The contributing causes to this root cause are described below.

\section{SOI Not Updated}

The formal method of communications between the Operations and Test Engineering was established in SOI 92-47. This represented a means for Operations and Test Engineering to communicate the status of the testing and the facility operations. The original testing method envisioned by SOI $92-47$ was not the method in use at the time of the event. Additional test engineering shifts had been added with different start and stop times. The SOI was not updated to reflect these changes and, as a consequence, the SOI came into disuse. 


\section{TYPE B INVESTIGATION REPORT FOR 241-SY-101 PUMP START AND 241-C-106 PIT CLEANOUT}

\section{SOI Not Utilized}

The formal communications described in the SOI were not used consistently. Despite the inadequates of the SOI, some of the information needed to make proper decisions could have been transmitted between Operations and Test Engineering.

\section{Pre-test Briefings Less Than Adequate}

The pre-test briefings did not consistently occur and contain sufficient information. The shift briefing did not always contain sufficient information to understand the intended testing activities or the current testing status. These briefings are a method to keep current on changing conditions and are necessary to assure Operations and Test Engineering were aware of each others intended actions.

The third root cause was the lack of operational control of the 241-SY-101 mixer pump during testing. The contributing causes to this root cause are described below.

\section{Interface Between Operations and Test Engineering Not Effective}

The interface and control requirements had changed as the test program progressed. SOI 92-47 had originally specified a method to accomplish the necessary interface and control, but testing methods and conditions had changed since the SOI was first issued. The SOI was not revised to reflect these changes. This formal administrative control became ineffective because as the testing method changed the revelance of the SOI to the actual conditions diminished. Additionally, management did not detect this change had occurred.

\section{Operations Role in Testing Not Adequately Defined}

Operations was fulfilling a support role in the testing despite statements by Operations and established policies. Test Engineering was really in charge of the testing and the operation of mixer pump. Because of this, Operations did not assume strong control. Their view was that the testing was occurring inside a "black box" with little or no impact on the operation of the facility. This lead directly to Operations failing to establish effective control over the pump operation.

\section{Disconnect Not Adequately Controlled}

The 241-SY-101 mixer pump disconnect was not controlled by the pump bump procedure. Operations could have established definitive control of the test boundries had they used a mechanical barrier, such as an operations lock on the disconnect switch and breakers. Additionally, a danger tag could have provided a more positive assurance that a more thorough review of conditions was made prior to closing the disconnect switch. 


\section{Independent Verification Not Performed}

Independent verification of the desired (or required) position of components is a means to ensure the component configuration is correct for the facility conditions. There were two opportunities to ensure what the proper position of the disconnect switch was: (1) at the time the shift supervisor directed closure of the disconnect switch; and (2) at the time the disconnect switch was actually closed.

\subsection{TANK 241-C-106 HEEL PIT CONTAMINATION EVENT}

The events and causal factors chart for 241-C-106 is provided as Figure 10. The root cause of this event was a less-than-adequate control of work. The principal contributing factors are discussed in the following paragraphs.

A number of barriers and controls failed that should have or could have prevented this event. Workers failed to understand the precise limits of the work scope. This was due to the rather general wording of the work package and imprecise verbal communication. The ALARA review failed because the ALARA committee was unaware of the scope change. The work control process was ineffective because the change process was not used. HP coverage of the activity, which could have detected and controlled the introduction of the rock into the riser, failed because the HPT was not physically present in the glovebox.

The glovebox was intended as a barrier between the workers and the high contamination inside the pit. The glovebox failed because it was bypassed. The protective clothing failed to provide an adequate barrier, due at least in part to the high temperatures in the pit.

\section{Failure To Incorporate New Scope}

The work plan was not modified to incorporate a new scope of work activities. The need to remove the standing water in the heel pit represented an additional work scope that had not been identified in the work planning performed to date. The significance of this change was not recognized. The entry into the containment invalidated the assumption in the RWP, with the result that the protective clothing required by the RWP was not adequate for the new task. When the job scope changed, the work package should have been modified to include the new task and any other additional controls necessary to safely perform the work. 


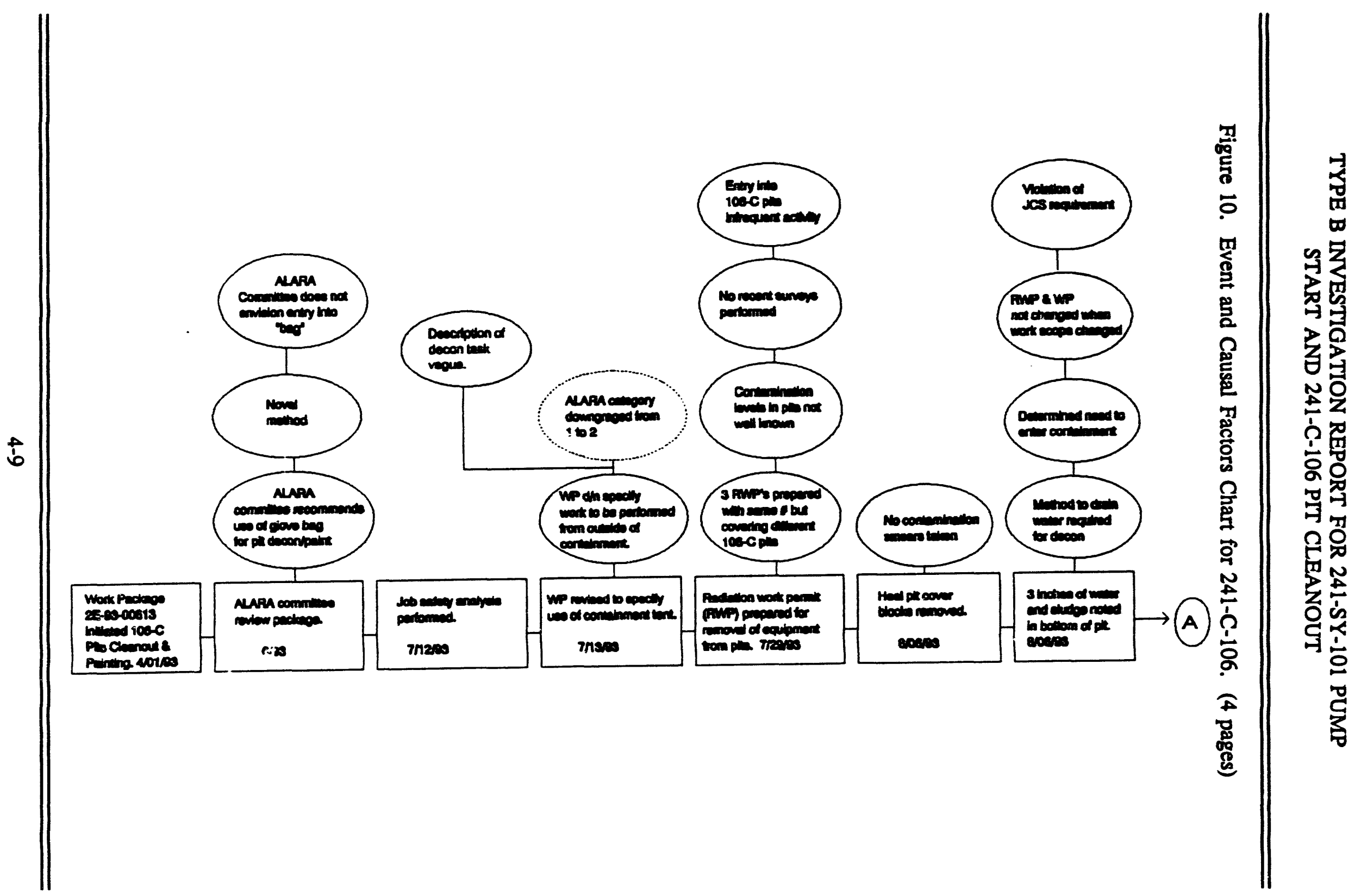




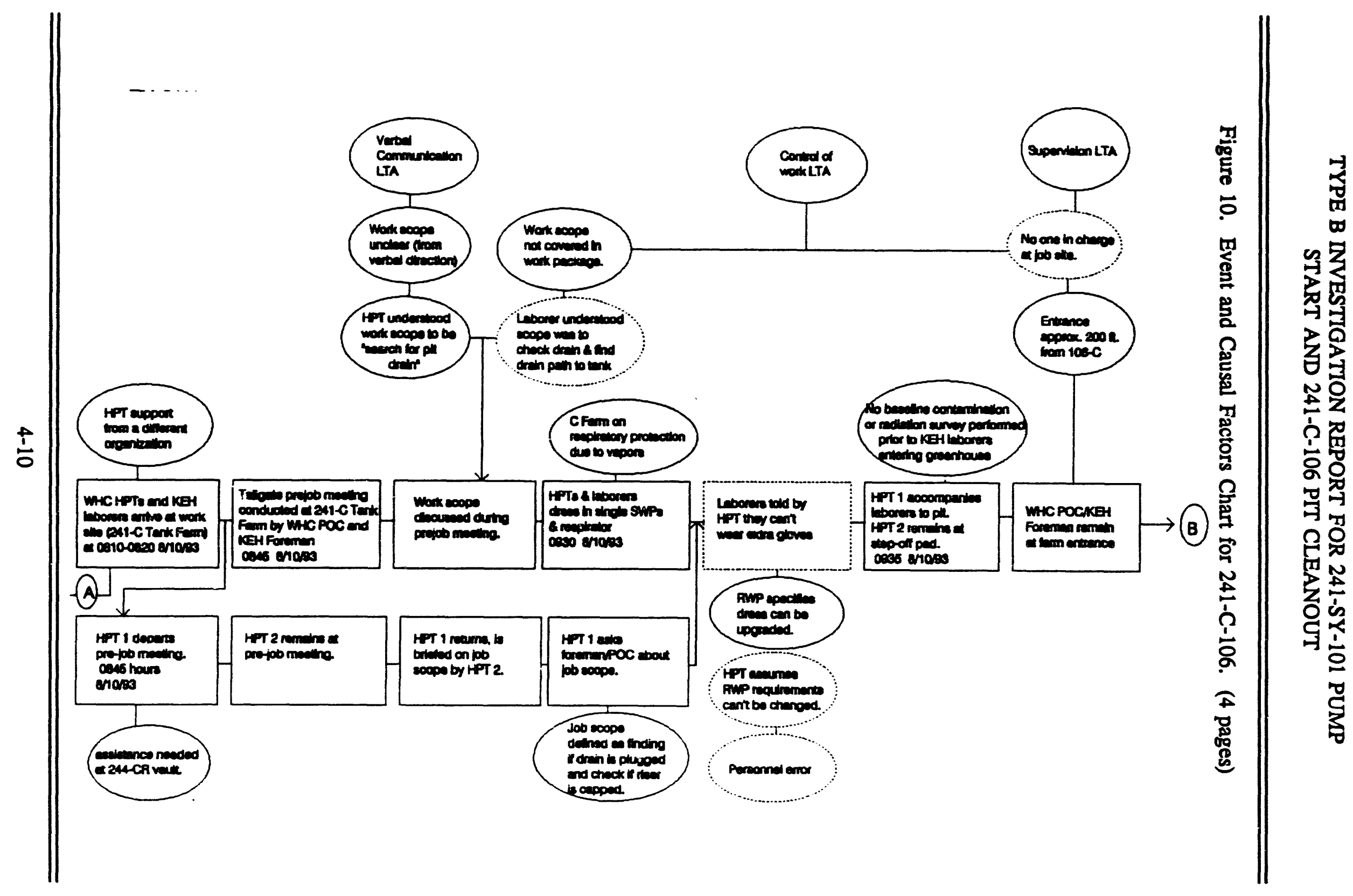




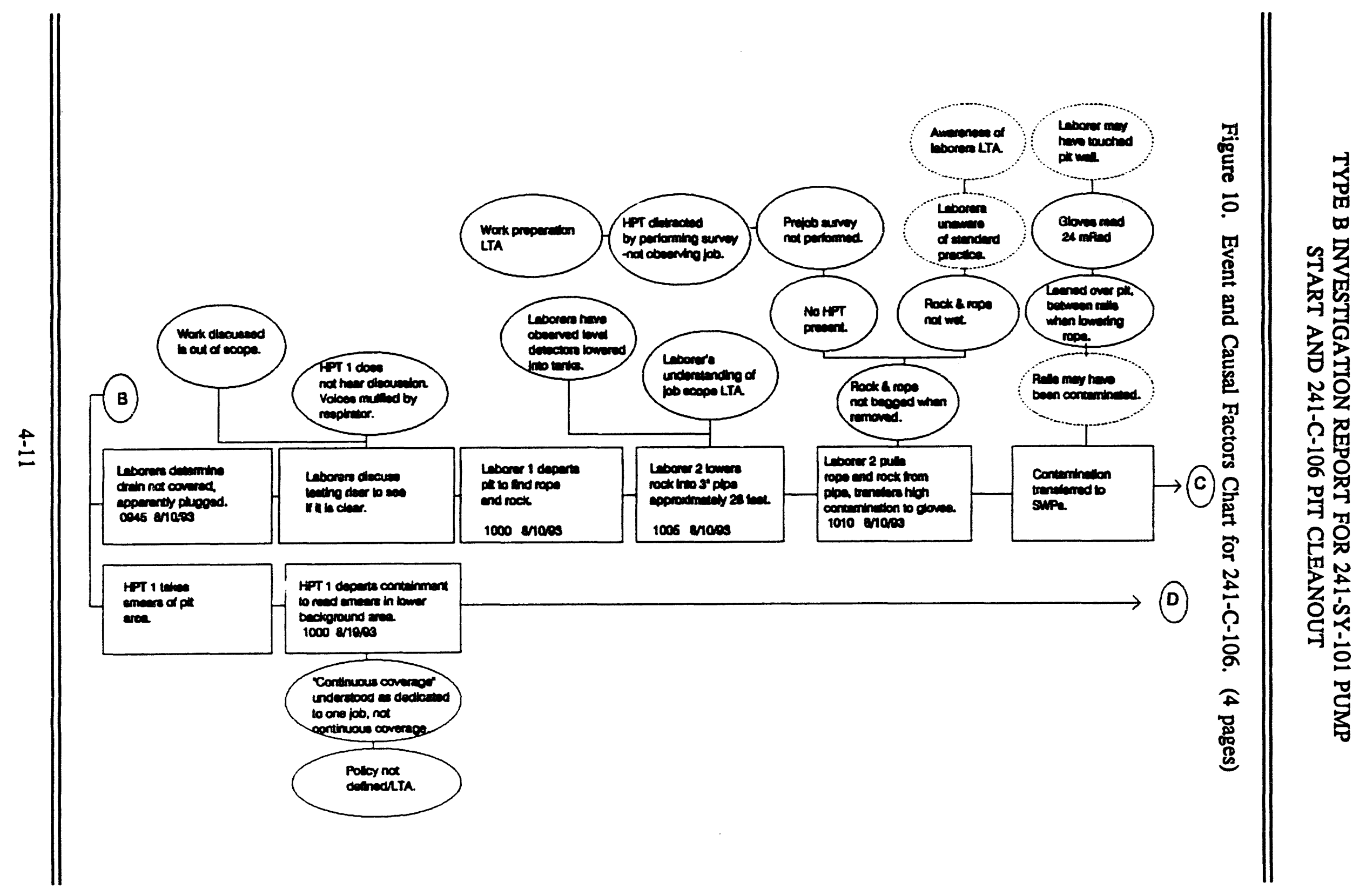




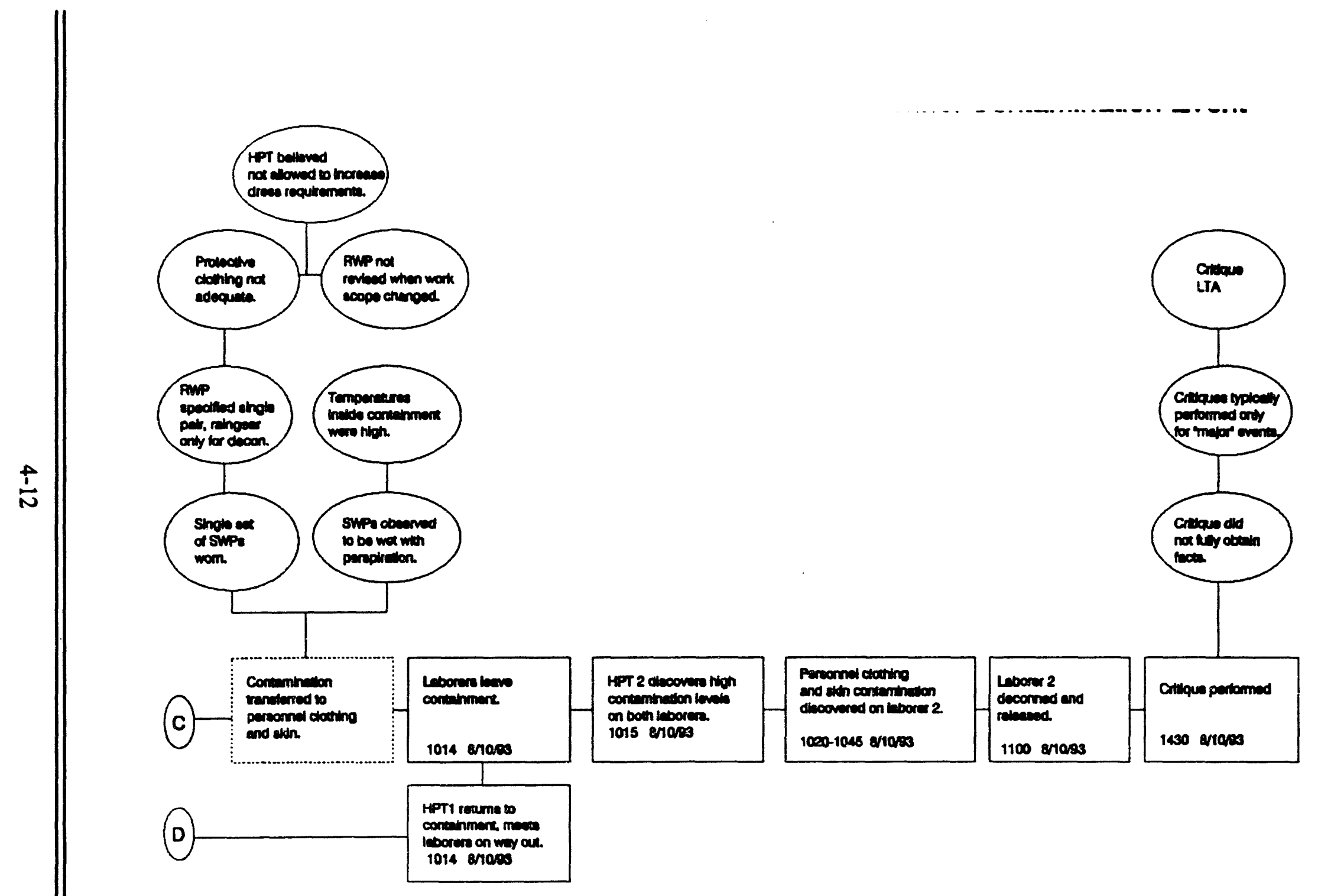

|| 


\section{TYPE B INVESTIGATION REPORT FOR 241-SY-101 PUMP START AND 241-C-106 PIT CLEANOUT}

\section{Inadequate Verbal Instructions}

The work scope was not adequately defined during the pre-job briefing. The verbal instructions given to the KEH workers did not definitively limit their activities. This resulted in the workers feeling that they had been given a mission that went beyond simply observing whether or not the existing drain was covered or the risers were capped. Since a baseline radiological survey had not been performed, the HPT was assigned that task, in addition to providing continuous coverage for the two workers. The HPT considered the survey to be his primary task. The consequence of this was his lack of awareness regarding what the workers were doing, and his decision to leave the containment before the workers had completed their task.

\section{Less Than Adequate Supervision}

Neither the WHC POC or the KEH foreman accompanied the workers into the containment. This was considered a relatively simple task that did not require close supervision. The HPT was concentrating on obtaining the background survey, and consequently did not effectively control the radiological aspects of the job.

\section{Less Than Adequate Training}

The WHC POC had not been trained as a person-in-charge (PIC), although he was functioning in that capacity. The KEH workers appear to have received sufficient training to allow them to recognize the innate hazards of the job, but not the results of their actions. They expected to have their protective clothing contaminated, and accepted this as part of the job.

\section{Lack Of Clarity In The Work Package}

The work package did not explicitly describe the technique to be used to perform the task. Due to concerns regarding the expected high contamination levels and radiation dose rates in the 241-C-106 pits (heel, pump, and sluice), the ALARA review recommended that the decontamination and painting be performed from outside the pits, using glovebox ports. The contamination controls specified in the RWP were based upon this concept. This recommendation was adopted in the planning of the work package; however, it was not explicitly described in the package. 


\subsection{GENERAL FACTS ANALYSIS}

In addition to the two recent events, the Board reviewed other 1993 occurrences related to Tank Waste Remediation System (TWRS) operations. From this review the following groupings of related causal factors were identified.

- Conduct of operations/operational practices

- Safety/safety practices/safety awareness

- Management/management structure/communications

- Management processes/work processes

- Radiological practices/contamination/radiation awareness and sensitivity.

The Board used these five groupings, in addition to the specifics from the two events, to form the basis of its analysis.

The analysis was made to identify weaknesses that may have contributed to the cause and severity of these two and other events. Observations of work activities and interviews with all levels of both the WHC and KEH organizations were conducted. Reviews of completed and in-process work packages and other documentation (including logs and records of rounds) were conducted. Training and qualification records were also reviewed.

Additionally, policies were reviewed and the understandings of these policies for all levels of personnel were tested. Results of overview of activities such as management surveillances, audit and QA surveillance reports, safety reviews and their status were reviewed.

The Board members were looking for performance and program elements that were significant and related to (or impacted the success of) the TWRS program and mission.

The discussion in this section, as well as the facts and findings sections, contains the results and conclusions of these investigations. Specifically, this section discusses and analyses five topics (Conduct of Operations, Safety, Management, Management Processes, and Radiological Practices), and how these topics contributed to safety "cultures" and the two events. 


\subsubsection{Conduct of Operations}

A review of the causal factors for the two subject events, and the results of interviews with operators, supervisors and managers, have identified a number of weaknesses in the Tank Farm Conduct of Operations. Principle weaknesses include:

- Inadequate management presence in the field

- Poor communications between operating groups and at pre-job briefings

- Insufficient fact finding at critiques

- Insufficient use of logs and shift turnover practices between operating groups and others performing work in the tank farm

- Inadequate use of timely shift orders.

These principal weaknesses all reflect poor communication processes. Good communications are fundamental to an effective operating facility. Failure to resolve the communication issues appears to result from the absence of regular line management involvement in day-today operating activities. When asked in interviews how much of their time line managers spent in the field, the answer generally was "very little or none." This observation was made by both managers and their employees.

The lack of a detailed Conduct of Operations implementation plan that includes significant involvement by line managers in observing, teaching, and setting performance standards has had a negative effect on the performance of all tank farm personnel. Efforts to improve performance following events in the past have not achieved desired goals. Workers view plant events/problems as the "systems" problem rather than accepting personal responsibility for making things better.

Interviews and observations have led to the conclusion that there is a pervasive insensitivity to degraded/degrading conditions and work practices on both the part of managers and workers.

\subsubsection{Safety}

Safety cultures are largely a product of safety sensitivity, the working environment, and management expectations and reinforcement. Required industrial and radiological training occurs at the Hanford Site. However, it appears that safety awareness is lacking in some areas. First line supervisors, work leaders, and employees need the appropriate awareness to stop and involve appropriate personnel when unusual conditions are encountered (e.g., water 
in the 241-C-106 pit). Workers must not proceed on activities without verifying the activity will not have adverse effects (e.g., closing disconnect switch or putting a rock down the pipe).

Safety perspectives are also influenced by the working environment. Personnel in the tank farms routinely work around areas of significant radiological contamination. In addition, equipment in the tank farm is, in some cases (lighting, exhausters), deteriorating. Many employees accept the current situation as the norm rather than as an unacceptable situation. Poor vertical communication with management, and lack of management presence in the field, led to continuation of this norm.

Management appears to be directing a strong safety philosophy, but there does not appear to have been significant progress in motivating people to work safely, making them accountable, and listening to and acting on their suggestions.

\subsubsection{Management}

The organization and administration of WHC tank farm operations must ensure effective implementation and control of operations activities. Experience has shown that superior, consistent performance is obtained from qualified personnel using approved procedures, especially in those cases where management is involved in workplace monitoring and performance assessment.

Stop work authority must be vested in each and every employee, and this authority must be reinforced and protected by management. The authority to stop work, especially for HPTs, is essential to the safety of personnel. Management must let their expectations be known by frequent, open, and free communication at all levels. Responsibilities (organizational and individual) must be clearly defined and must facilitate safety culture ownership and operational excellence.

The organizational arrangement, responsibilities and processes are established in several places. Organization charts define the organizational hierarchy. Responsibilities and processes are defined in Conduct of Operations manuals, management policies, and governing work control procedures.

This review identified three underlying organizational issues that contributed to the two events. The issues are as follows:

- Division of responsibilities inhibited effective use of processes

- Organizational structure did not encourage task ownership

- Vertical communication within organizations was less than adequate. 
Each of the issues is discussed in more detail below.

4.3.3.1 Division of Responsibilities. Division of responsibilities was an issue in both events. In the 241-SY-101 event the division of responsibilities was not well defined between Shift Operations and Test Engineering. Although an SOI existed, it had not been updated when plant conditions changed and the agreements in the SOI were not actively in use. Operations personnel had only limited participation or knowledge of the 241-SY-101 pump testing. Since the equipment was in a test phase, Operations personnel were unsure of their responsibilities. Test Engineering felt responsible for testing, but not for other tank activities, and did not encourage involvement by Operations. They did not have a focus on ensuring long term success when the equipment was operated by Operations.

Division of responsibilities was a contributing factor in the 241-C-106 event in that the roles of the WHC POC and KEH Superintendent/Foreman were not clearly defined.

4.3.3.2 Organizational Structure. The organizational structure of Waste Tank Operations and Health Physics did not encourage task ownership. Many organizations are grouped by discipline (e.g., mechanical, electrical) or functionally (e.g., single shell tanks) rather than by plant area. Personnel move from a task in one area to the next task in another area. Each new task brings a new grouping of individuals. For these reasons constant work groups are rare. In the case of the 241-SY-101 event, shift operations personnel worked rotating shifts while the test engineers worked straight shifts. The "expert" shift supervisor was not present on-site. At the time of the event one of the operators was inexperienced, having been temporarily assigned from the 200 East facilities for the day shift.

For the 241-C-106 event, the HP personnel assigned to the job changed each week. In addition, a relatively inexperienced HPT was the only HPT who attended the pre-job briefing.

Organizational structure is also a factor in the number of management levels. Ownership and accountability would be better promulgated by a horizontal management structure.

4.3.3.3 Vertical Communication. Communication of priorities, management expectations, milestones/schedules, and equipment/process issues was less than adequate. The involved organizations have up to six management levels. This number of levels makes effective vertical communication difficult. Also, as noted earlier, there was little management presence in the field to detect issues or problems. Without effective top-down communication or management presence in the field, the field performance standards did not improve as required.

Vertical communication is also important to eliminate unintended messages to the field such as "production is more important than safety" or "you must live with safety issues." Examples of these types of problems are given in Section 3.3.2. 


\subsubsection{Management Processes}

4.3.4.1 Maintenance Process. The long delay in maintenance package preparation and delivery causes a maintenance personnel concern, since there is not sufficient time to prepare, get the work packages corrected (a common need), gather the necessary material, hold a pre-job briefing, and still do the work.

The emphasis on work package completion, coupled with the sometimes poor quality work packages and general lack of coordination, gives the impression to the work force that management only cares about production and not worker safety. Crafts felt this practice was contrary to the stated safety goals delivered by management.

4.3.4.2 Test Controls. In the 241-SY-101 mixer pump inadvertent start, testing was not sufficiently controlled. Many factors contributed to this event, but the interface control of the routine operation of "pump bumping" with the on-going testing did not exist. No procedure had been established to ensure control, nor had an effective method been established to coordinate the testing and routine pump bumping.

From interviews, the situation that resulted in the inadvertent pump start is not uncommon. The organizational structure can allow testing, projects, and some maintenance to be conducted without the knowledge of shift operations. In many cases, individuals overcome the structure and processes in order to keep all informed.

4.3.4.3 Prioritization/Funding. WHC-IP-0842 establishes formal guidelines for prioritization of work. The large backlog of work packages, occurrence reports, audit findings, and waste issues (as well as the large number of external issues), has caused the system to become overwhelmed. To compound the problem, the lack of supporting infrastructure (such as accurate as-built drawings and labeling) has made the process even more difficult. In addition, the number of components that fail due to age, and the difficulty of obtaining the necessary parts, further increases the number of work requests and the time it takes to complete them.

Most interviewees indicated that only the highest priority items of the J-1 tasks are being worked. It is believed that tasks related to the Tri-Party Agreement milestones have a higher priority than tasks that are related to worker safety (i.e., replacing lights in the tank farms or fixing tank level indicators). Worker safety tasks are to be given Priority 1 status; however, unless an item is clearly marked "Safety," it may be given a lower priority and will never be worked. 


\subsubsection{Radiological Practices}

4.3.5.1 ALARA. The radiological planners failed to follow up to ensure that the RWP and work plan for the decontamination and painting of the 241-C-106 pits met the intent of using the enclosure as a glove bag (no entry).

Mockup training was not performed for this job despite the following:

1. High dose rates, high contamination levels, and the use of air-line respirators were anticipated in the RWP.

2. The glovebox technique for contamination control of a tank pit is a new technique at the tank farms.

3. Kaiser personnel were unfamiliar with the use of gloveboxes.

4.3.5.2 RWP/Workplan. Personnel failed to recognize the significance of the job scope change once water and sludge were detected and it was decided to allow personnel to enter the glovebox. The RWP and work plan did not explicitly discuss the use of the glovebox. The radiological protection requirements were written for work outside the glovebox only.

Three RWPs, all identified with the same number, were written to describe work in the heel pit, sluice pit, and the pump pit with identical radiological controls. This could be a cause of additional confusion.

4.3.5.3 Pre-job Briefings. The pre-job briefing was held by the POC at the work site. This practice can create an air of informality and is distracting to workers who need to comprehend all details of the job.

The HPT was called away to cover another job during the briefing. Not being present at the pre-job briefing is bad practice and contributes to poor communication.

Presentation of the work scope was not clear. The HPT perceived that the job scope was limited to the workers using a rake to attempt to remove a possible drain cover or loosen sediment to unclog the drain. The workers perceived they were assigned the task to discover a method of transferring water from the pit floor into the tank.

The inherent dangers of the tank were never discussed, and it was assumed that all the workers knew to limit actions involving possible contact with contents of the tank. Discussions with operations personnel demonstrated that the use of "zipcords" for tank level indicators, the replacement of broken aging permanent indicators, and the dipping of bottles into various waste tanks for samples occur routinely. 
4.3.5.4 Radiological Coverage. Allowing entry into an area that has not been surveyed for several years prior to a pre-job survey is poor radiological practice. Confirmation of the RWP dose rate and contamination estimates should have been performed prior to work in the pit. If the HPT had stayed at the job site and concentrated on job coverage instead of performing a survey and leaving to count smears, he could have provided additional direction and possibly prevented the event. Interviews indicate that KEH workers generally solicit advice and direction from HPTs.

"Continuous" coverage is not well defined. Current interpretations allow HPTs to provide continuous coverage for more than one job even though the jobs may be separated by considerable distance.

\subsection{ANALYSIS OF ROOT CAUSES}

The above analysis discussions have dealt with the two specific incidents and the five general topics arising from the review of the 1993 occurrences at TWRS. Taking these areas and reviewing them together, three causes became apparent. One underlying cause relating to less than adequate communications runs through the 241-SY-101 pump incident and the 241-C-106 pit cleanout, as well as the Conduct of Operations discussion.

A second cause that touches on several incidents was the lack of implementation of a strong Conduct of Operations philosophy. The tolerance for degraded plant conditions and equipment, and inadequate processes, appears as a cause (the third) in the safety, radiological, and management process sections.

Also, a stated and sometimes unstated causal factor that appears in several of the analysis sections (241-C-106 pit clean out, safety and radiological practices, etc.) is the awareness of or sensitivity of personnel to conditions, hazards, or changes that could result in unintended action if planned evolutions were to proceed.

Taken together, the three common causes result in this lack of sensitivity of personnel at all levels to safety and radiological hazards. Field personnel fail to recognize the need to stop and consult with experts when unusual or unanticipated conditions are encountered. Instead, they attempt to solve issues without full knowledge of the results of their actions.

Actions to correct any one of the elements of the triad of causes will not have an immediate affect on the lack of sensitivity. All elements of the triad need to be addressed in order to effectively decrease this lack of sensitivity. The causal triad forms an interactive relationship with its primary effect being lack of sensitivity. 


\subsection{CONCLUSIONS}

\subsection{FINDINGS FOR 241-SY-101 EVENT}

\subsubsection{1-SY-101 Findings}

5.1.1.1 241-SY-101 Finding \#1: Operations had inadequate knowledge of the mixer pump test procedures.

Causal Factors for Finding \#1:

- Operations had no formal training on the mixer pump and associated systems or the test procedures. This resulted in limited knowledge of the ATP content.

- The pump is a prototype and, as such, is a unique component. The pump was never intended to be turned over to operations.

\section{Judement of Need for Finding \#1:}

The operations/test engineer activities must have clear definition of training requirements for operations and test personnel. This should include sufficient technical training to ensure operations and test personnel understand the possible impacts of test activities on existing plant equipment, as well as plant evolution effects on testing activities.

5.1.1.2 241-SY-101 Finding $\# 2$ : Communications of test activities were inadequate between Operations and Test Engineering.

Causal Factors for Finding \#2:

- The interface requirements had changed as the test program progressed, but SOI 92-47 had not been revised to reflect these changes (e.g., the bump pump requirements).

- SOI 92-47 was not followed rigorously, which would have ensured some communication about test activities despite the inadequacies of the SOI.

- The pre-test and shift briefings did not always occur or contain sufficient information for the operations personnel to understand the intended testing activities or current testing status. 


\section{Judgment of Need for Finding \#2:}

Operations management must periodically review the adequacy of communications between operations and testing personnel. The management oversight and monitoring requirements of Chapter 1.0 of the Conduct of Operations Manual should be aggressively implemented.

5.1.1.3 241-SY-101 Finding \#3: Operations' lack of definitive control of the mixer pump resulted in the inadvertent start of the pump.

\section{Causal Eactors for Finding \#3:}

- The control requirements had changed as the test program progressed, but SOI 92-47 had not been revised to reflect these changes.

- Despite statements by Operations and established policies, Test Engineering was in charge of the testing and the operation of the mixer pump; Operations was fulfilling a support function. Operations did not demonstrate sufficient interest in the testing.

- The 241-SY-101 mixer pump disconnect switch was not controlled procedurally by the pump bump procedure, nor was there a mechanical means (lockout device) used to prevent closure of the disconnect switch.

- Independent verification of the 241-SY-101 mixer pump status did not occur.

\section{Judgment of Need for Finding \#3:}

Implement the philosophy of operational control over testing as set forth in Chapter 8 of the Conduct of Operations manual.

5.1.1.4 241-SY-101 Finding \#4: Operations and test personnel were not immediately evacuated outside the 300 meter exclusion zone following the inadvertent pump start.

\section{Causal Factors for Finding \#4:}

- The significance of the fact that the mixer pump had actually run, and that the potential existed fo: gas release from the tank, was not recognized.

- There is no locally-installed means to alert personnel that the mixer ;ump is running, nor is there a public address system. 


\section{Judgment of Need for Finding \#4:}

Establish a means of assuring all personnel are immediately alerted and evacuated when 241-SY-101 pump operations occur.

\subsection{FINDINGS FOR 241-C-106 EVENT}

\subsubsection{1-C-106 Findings}

5.2.1.1 241-C-106 Finding \#1: The 241-C-106 pit event resulted from work performed that was outside the scope of the approved work package and RWP.

\section{Causal Factors for Finding \#1:}

- The scope changes (water in the pit and rock in tank) were not recognized as significant enough to require work package replanning. The entry into the containment was not covered in the work package or the RWP.

- The scope and limitations of the task were not clearly communicated to the workers, either in the work package or in the pre-job briefing.

- The Point-of-Contact, the HPT attending the pre-job briefing, and the KEH foremen and workers were relatively inexperienced at working on jobs with high radiation/contamination risks.

- Continuous HPT presence was not maintained.

\section{Iudement of Need for Finding \#1:}

The threshold of sensitivity to changes in work conditions and work scope for all activities must be lowered, thoroughly understood, and acted upon by all personnel.

5.2.1.2 241-C-106 Finding \#2: The general wording of the RWP and work plan did not preclude entry into the glovebox.

Causal Factors for Finding \#2:

- The RWP and work plan were vague and not specifically written to address the original scope and restrictions of the job. 
- Estimates of radiological conditions used to develop the RWP were developed using historical data; they were not verified at the start of work.

Judgment of Need for Finding \#2:

- Improve ALARA planning and field implementation to assure the plans are effective and the goals of ALARA are achieved.

\subsection{RELATED ISSUES}

\subsubsection{Conduct of Operations}

5.3.1.1 Conduct of Operations Finding. Although well documented by policy and procedures, the Conduct of Operations principles at the WHC waste tank farms have not been successfully implemented and have not resulted in an acceptable level of performance.

\section{Causal Factors for Finding:}

- There is no formal progressive, self-validating plan or schedule for implementing Conduct of Operations.

- Vertical communications, management presence in the field, and structured communications between organizations are insufficient.

\section{Judement of Need for Finding:}

Chapter 1 of the Westinghouse GOCO Conduct of Operations manual, although entitled "Operations Organization and Administration," contains the philosophy for conducting operations and the guidance for correctly implementing the remaining 17 chapters. When properly understood and followed by line management, Chapter 1 becomes the foundation for the overall Conduct of Operations program.

WHC waste tank farms management must (1) revisit and become thoroughly familiar with the contents of Chapter 1 ; $(2)$ develop a plan for further improvements in conduct of operations; and (3) execute the plan with the participation and support of all levels of management and supervision. 


\section{TYPE B INVESTIGATION REPORT FOR 241-SY-101 PUMP START AND 241-C-106 PIT CLEANOUT}

\subsubsection{Safety}

5.3.2.1 Safety Finding \#1. Contamination areas, tripping hazards, and out of service equipment (such as tank farm lights and exhausters) are a common occurrence and have a low probability of being fixed.

\section{Causal Factors for Findine \#1:}

Insufficient priority is placed on resolution of routine safety concerns and plant equipment deficiencies. Highly visible programs (such as remediation of tank contents) receive the highest priority for resources.

\section{Judgment of Need for Finding \#1:}

Increase the visibility and priority of repairing out-of-service equipment and correcting contamination control and industrial safety problems.

5.3.2.2 Safety Finding $\# 2$. The work force doubts management's commitment to safety.

\section{Causal Factors for Finding \#2:}

Lack of resolution of work force concerns convinces workers that safety is not the highest priority.

\section{Judgment of Need for Finding \$2:}

Strong action from management to fix unsafe conditions is essential to convince the work force of the company's intent to be safe.

5.3.2.3 Safety Finding \#3. Management expectations for the work force with respect to safe conduct of work are not clear.

\section{Causal Factors for Finding \#3:}

- Unintended messages are received by the work force when rewards for work stoppages and satisfactory resolutions are rare compared to rewards for completing work on schedule.

- Management has not maintained an adequate presence in the work place to set and reinforce the safety culture. 


\section{Judement of Need for Finding \#3:}

Management presence at the start of work evolutions, during work evolutions, and in one-on-one conversation with workers is needed to fully understand and be effective at resolving work force issues.

\subsubsection{Management}

5.3.3.1 Management Finding. There is insufficient ownership, teamwork, and support for cultural change within organizations working in the tank farms.

\section{Causal Factors for Finding:}

- Organizations are aligned for different functions (i.e., plant areas versus technical topics) versus skill disciplines (e.g., mechanical, electrical).

- Key organizations needed for work planning and performance are not commonly located, assigned, and transported to work sites.

- Operations and Health Physics field personnel do not believe they have sufficient input to facility priorities.

- Management presence in the field is limited and vertical communications are distorted by management layers and physical separation.

\section{Judgment of Need for Finding:}

Modify the organizational focus to facilitate ownership, teamwork, and communication.

\subsubsection{Radiological Practices}

5.3.4.1 Radiological Practices Finding \#1. Pre-job surveys are not routinely performed exclusive and prior to the planned work activity. Survey results are not compared to the RWP estimates prior to starting work.

\section{Causal Factors for Finding \#1:}

- Misapplication of ALARA concepts and productivity pressures have led to this practice.

- Lack of sensitivity to changing radiological conditions. 


\section{Judgment of Need for Finding \#l:}

Establish definitive controls and specific guidance for when pre-job surveys must be performed; ensure that they are reviewed prior to the start of the work activity.

5.3.4.2 Radiological Practices Finding \#2. There are various levels of understanding by Health Physics of the definition and requirements for performance of "continuous coverage."

\section{Causal Factors for Finding \#2:}

- HPT management has provided conflicting verbal definitions for the meaning of continuous coverage.

- The Hanford Radiological Control Manual fails to provide a definition for the term "continuous coverage."

- Current work practice allows the HPTs to leave the area for brief periods of time.

- Individual HPTs are currently assigned more than one work activity requiring continuous coverage.

Judgment of Need for Finding \#2:

Provide a clear definition of and implement a system for continuous coverage. 
This page intentionally left blank. 
TYPE B INVESTIGATION REPORT FOR 241-SY-101 PUMP

START AND 241-C-106 PIT CLEANOUT

APPENDIX A

COMMISSIONING LETTER 
This page intentionally left blank. 


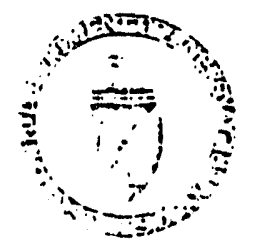

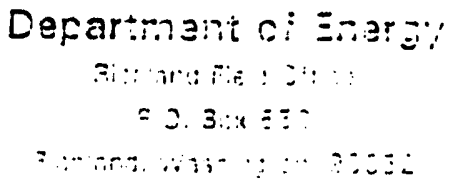

AUG 171993

93-TOB-160

Mr. T. M. Anderson, President

Westinghouse Hanford Company

Richland, Washington

Dear Mr. Anderson:

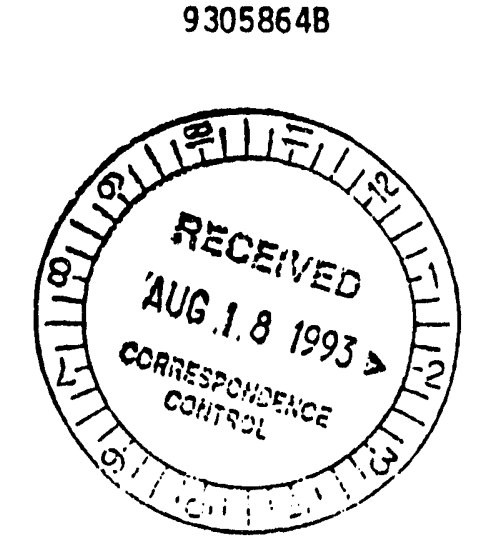

TYPE "B" INVESTIGATION OF RECENT TANK FARM EVENTS

Confirming conversations with your staff, the Westinghouse Hanford: Company (WHC) is requested to conduct a Type " $B$ " Investigation of the recent events which occurred in the tank farms complex. The events involved "Inadvertent Mixer Pump Operation at 101-SY," RL-WHC-TANK FARM-1993-069 and "Inadequate Work Control Resuits in Personnel Skin Contamination at 241-C-106, Pit B," RLWHC-TANK FARM-1993-0071.

Mr. J. L. Lee has been appointed Chatrman of the WHiC investigation board. The names and qualifications of the members selected to assis.t Mr. Lee are:
J. L. Lee, Chatrman
Manager, Operations
Waste Isolation Division

J. R. Ewalt

Professional, Total Quality and Performance

R. F. Gessner

Evaluation, Trained Accident Investigator
L. J. Garvin
D. H. Shuford
S. Smith
C. E. Upchurch

Manager, Plant Operations

Hest Valley Nuclear Services Company

Consulting Technical Analyst Kaiser Engineers Hanford

Manager, Special Projects; Root Cause Analyst

Manager, Operations Integration, Westinghouse Savannah River Company

Radiation Protection Supervisor

Kaiser Engineers Hanford

1 have selected Mr. Andrew Hon to be an observer and to provide liaison between RL and the board. 
Your Type " $B$ " investigation is to be conducted using DOE Order 5484.1, and the report is to be submitted to me by September 13, 1993. The report should fully explain the elements of the causal factors and describe the management systems which should have, or could have, prevented the occurrence.

Appropriate judgement of needs for improvement of the management systems w111 be required.

If you have any questions, please contact me or your staff may contact Mr. Andy Hon, Office of Performance Assessment on 376-7127.

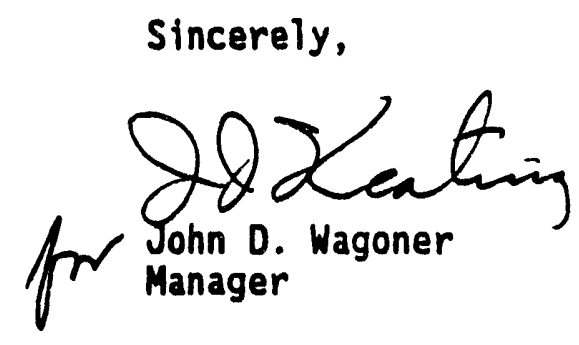

CC: J. C. Tseng, EM-36/HQ

A. Griffith, EM-36/HQ 


\section{APPENDIX B}

BOARD MEMBERS 
This page intentionally left blank. 


\section{SIGNATURES}

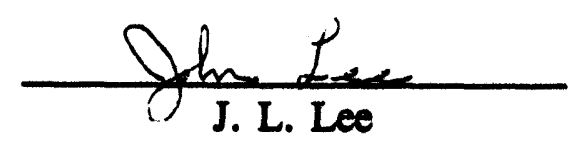

Operations Manager Westinghouse

Waste Isolation Division

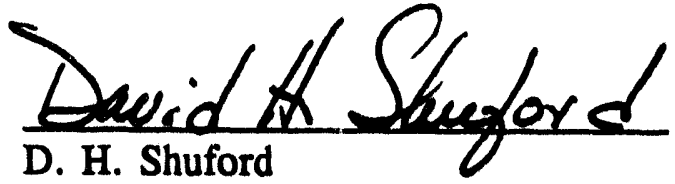
Acting Manager, $\mathrm{UO}_{3}$ Plant

Westinghouse Hanford Company

$$
\text { R. Ewalt }
$$

Certified Accident Investigator

Westinghouse Hanford Company

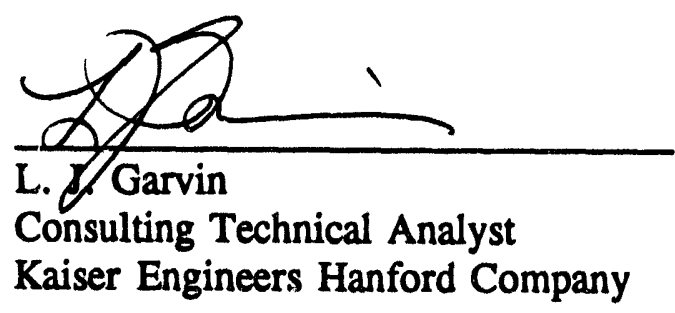
$\frac{\operatorname{lom} 1 \text { ee tw- Rfliesiner par telecun }}{\text { R. F. Gessner }}$ Manager Site Operations West Valley Nuclear Service Company S. Jom fex tor 5.J s.n.ch per teleci:Manager, Operation Integration Westinghouse Savannah River Company

Anjelachue

C. E. Upchurch Supervisor Health Physics Kaiser Engineering Hanford Company

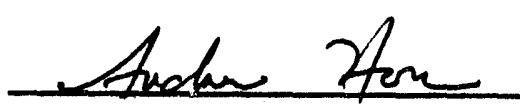

A. Hon, DOE-RL

Nuclear Safety Engineer

DOE Observer 


\section{BOARD MEMBERS RESUMES}

Ewalt, J. R. - Board Member

Senior Engineer, Total Quality and Performance Evaluation

Westinghouse Hanford Company

MORT/AI certified. Twenty-one years experience in the nuclear industry, including the Navy and Fast Flux Test Facility at various qualification levels in operations. Responsible for the startup of Institute of Nuclear Power Operations Human Performance Enhancement System at the Fast Flux Test Facility. Participated as both board leader and member in a number of investigations and Conduct of Operations assessments.

Garvin, L. J. - Board Member

Consulting Technical Analyst, Waste Handling Projects Division Kaiser Engineers Hanford

Degrees in Chemical, Nuclear, and Metallurgical Engineering. Over 30 years experience in the nuclear industry. Experience includes nuclear construction, Naval Nuclear Power Instructor, NRC Inspector, and Quality Assurance and nuclear safety management.

Gessner, R. F. - Board Member

Manager, Site Operations

West Valley Nuclear Services Company

Graduate Metallurgical Engineer. Over 40 years experience in nuclear materials, nuclear fabrication, nuclear reactor plant maintenance, waste treatment and contamination. Responsible for developing and implementing GOCO Conduct of Operations manual and training. 
Andrew Hon - Observer

Nuclear Safety Engineer and Lead Auditor, Nuclear Safety and Quality Assessment Staff, Office of Performance Assessment, DOE-RL.

B.S. Nuclear Engineering, Professional Engineer, Maryland; NQA-1 Lead Auditor, and DOE Accident Investigator. Sixteen years of professional experience in nuclear safety and quality. This includes leading safety and quality audits, and investigating DOE events. NRC Resident Inspector and Reactor Inspector at commercial nuclear power plants. Represented the NRC to commercial nuclear utilities in enforcing federal nuclear regulations and investigating onsite events. Professional experience includes reactor safety research for nuclear accident analyses and regulation development.

Lee, John L. - Board Chairman

Manager, Waste Isolation Pilot Plant Operations

Westinghouse Waste Isolation Division

BS and MS degrees in Chemical Engineering. Seventeen years experience in technical support and operations management at DOE facilities. Experience includes fourteen years at the Idaho Chemical Processing Plant managing nuclear fuels dissolution, uranium recovery, and high and low level waste storage and processing. Current assignment is WIPP Operations Manager includes responsibility for managing facility operations, maintenance, procedure development and implementation of Conduct of Operations and Maintenance.

Shuford, D. H. - Board Member

Acting Manager, $\mathrm{UO}_{3}$ Plant

Westinghouse Hanford Company

M.S. Chemical Engineering. MORT/AI trained. Twelve years nuclear industry experience. Background in N Reactor technology support, project engineering, chemical processing systems engineering, operations programs and operations support. Outage Manager during preparations for the final $\mathrm{UO}_{3}$ Plant processing campaign. 


\section{TYPE B INVESTIGATION REPORT FOR 241-SY-101 PUMP

Smith, Stephen J. - Board Member

Manager, Operations Integration

Westinghouse Savannah River Company

27 years nuclear experience including U.S. Navy, commercial, and government nuclear programs. Held senior management positions including Plant Manager of Sequoyah Nuclear Station and Manager, Reactor Operations, at Savannah River Site. Has participated in 5 previous Type "B" investigations. Responsible for Conduct of Operations implementation at the Savannah River site.

Upchurch, C. E. - Board Member

\section{B. S. Zoology}

Twelve years of experience in the nuclear industry. Held positions in health physics and emergency planning at several commercial nuclear power facilities. Member of the National Registry of Radiation Protection Technicians. 
TYPE B INVESTIGATION REPORT FOR 241-SY-101 PUMP

START AND 241-C-106 PIT CLEANOUT

APPENDIX C

ORGANIZATION CHARTS

C-1 
This page intentionally left blank. 

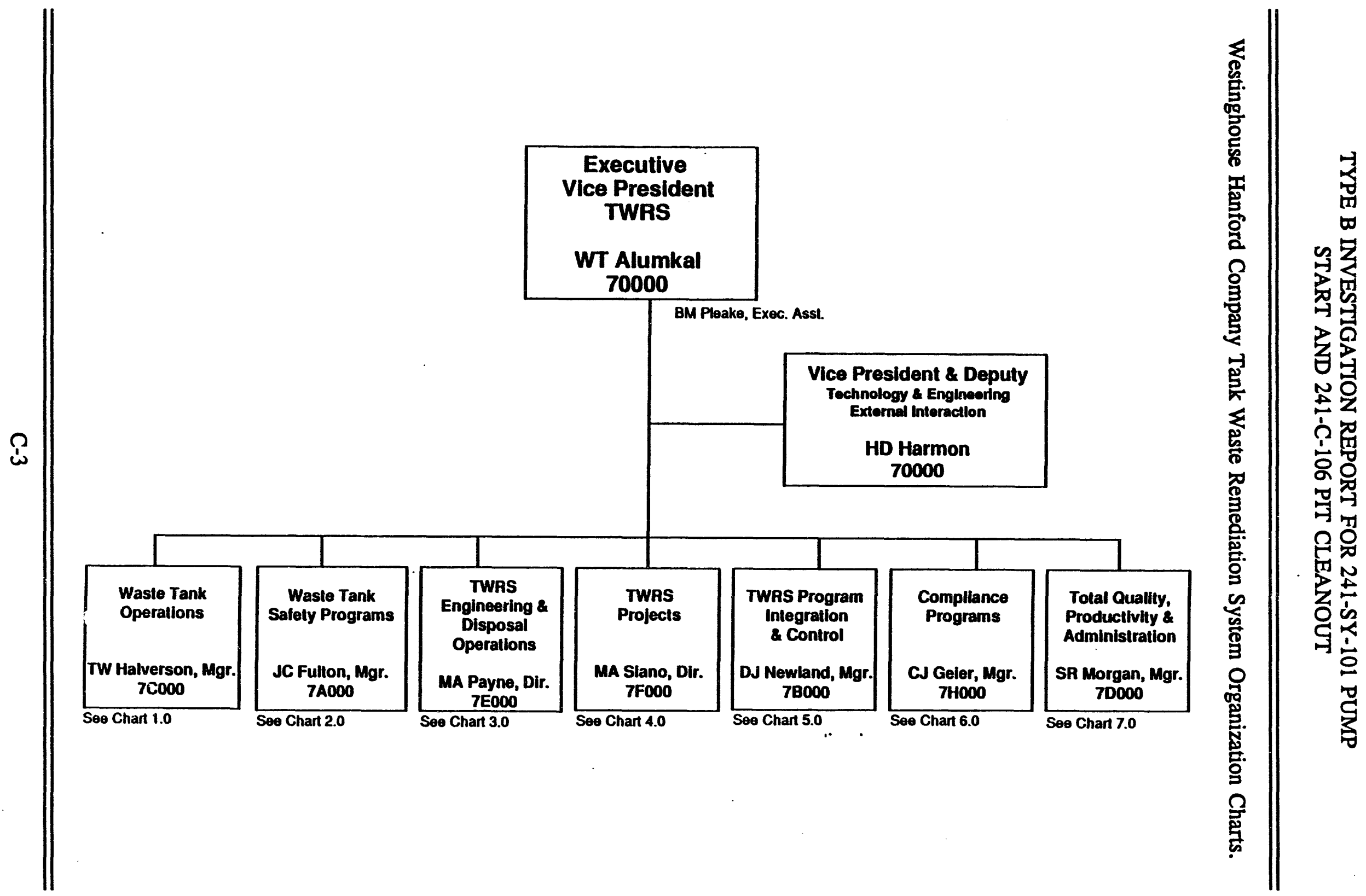

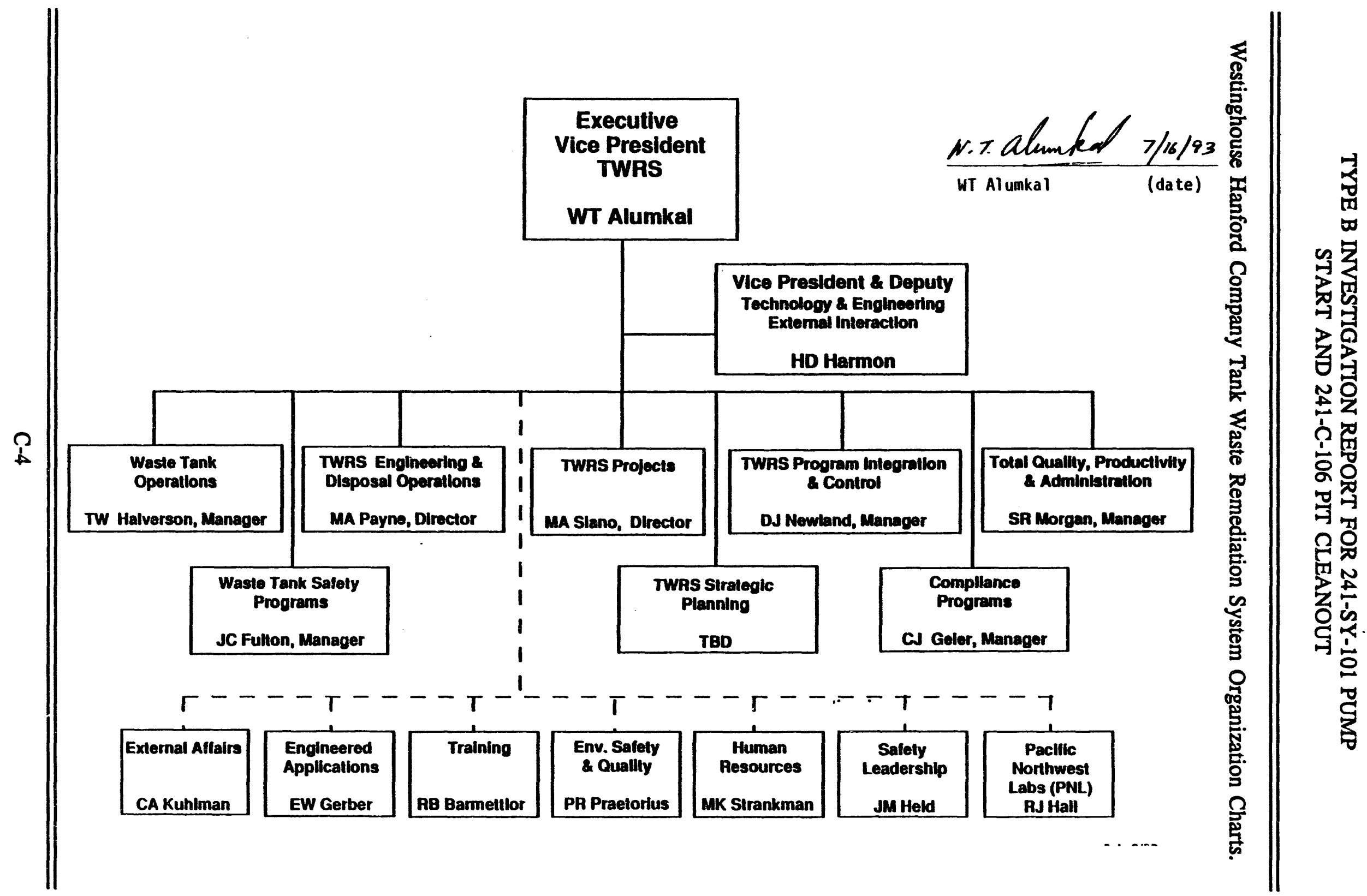


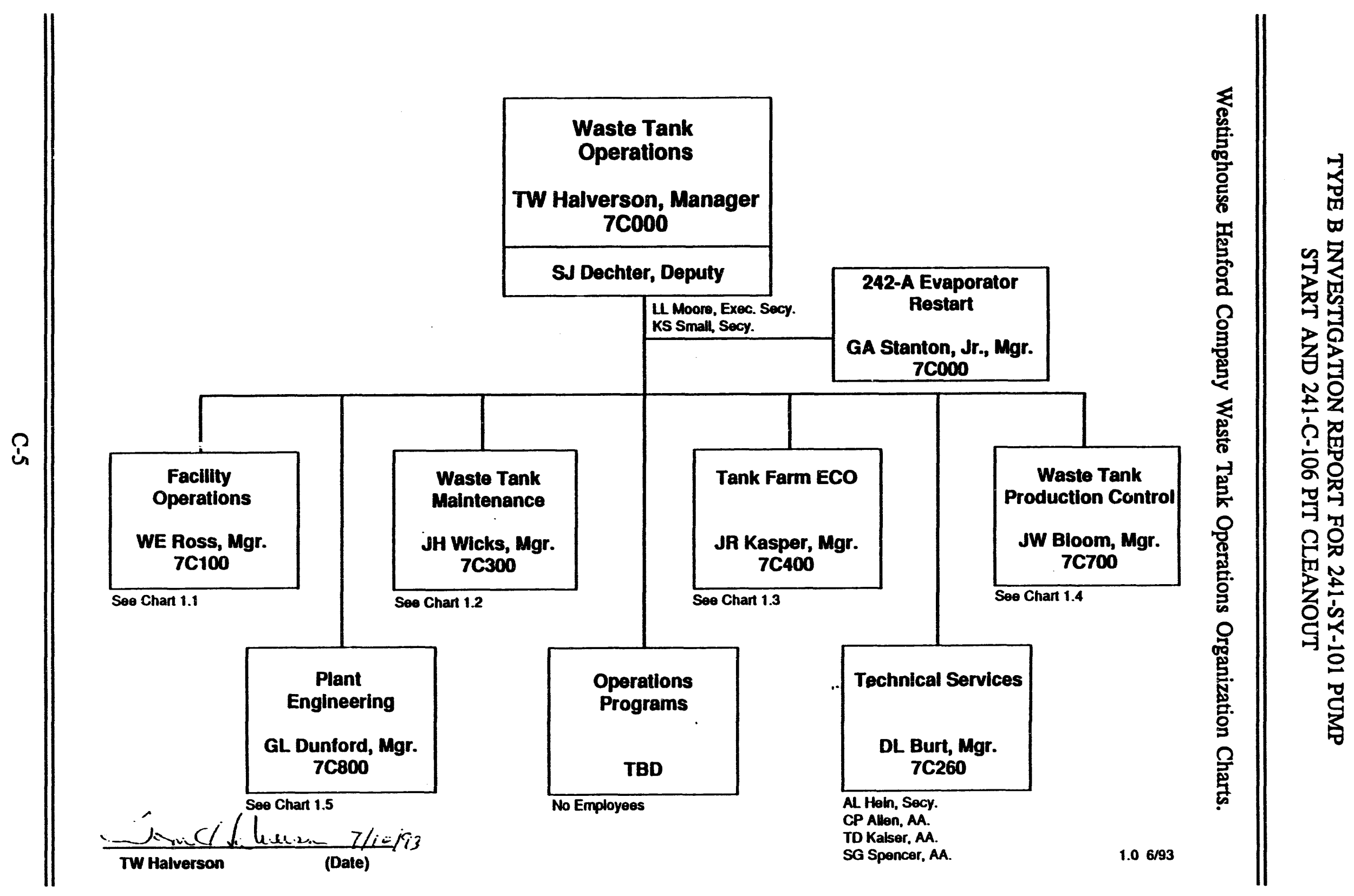




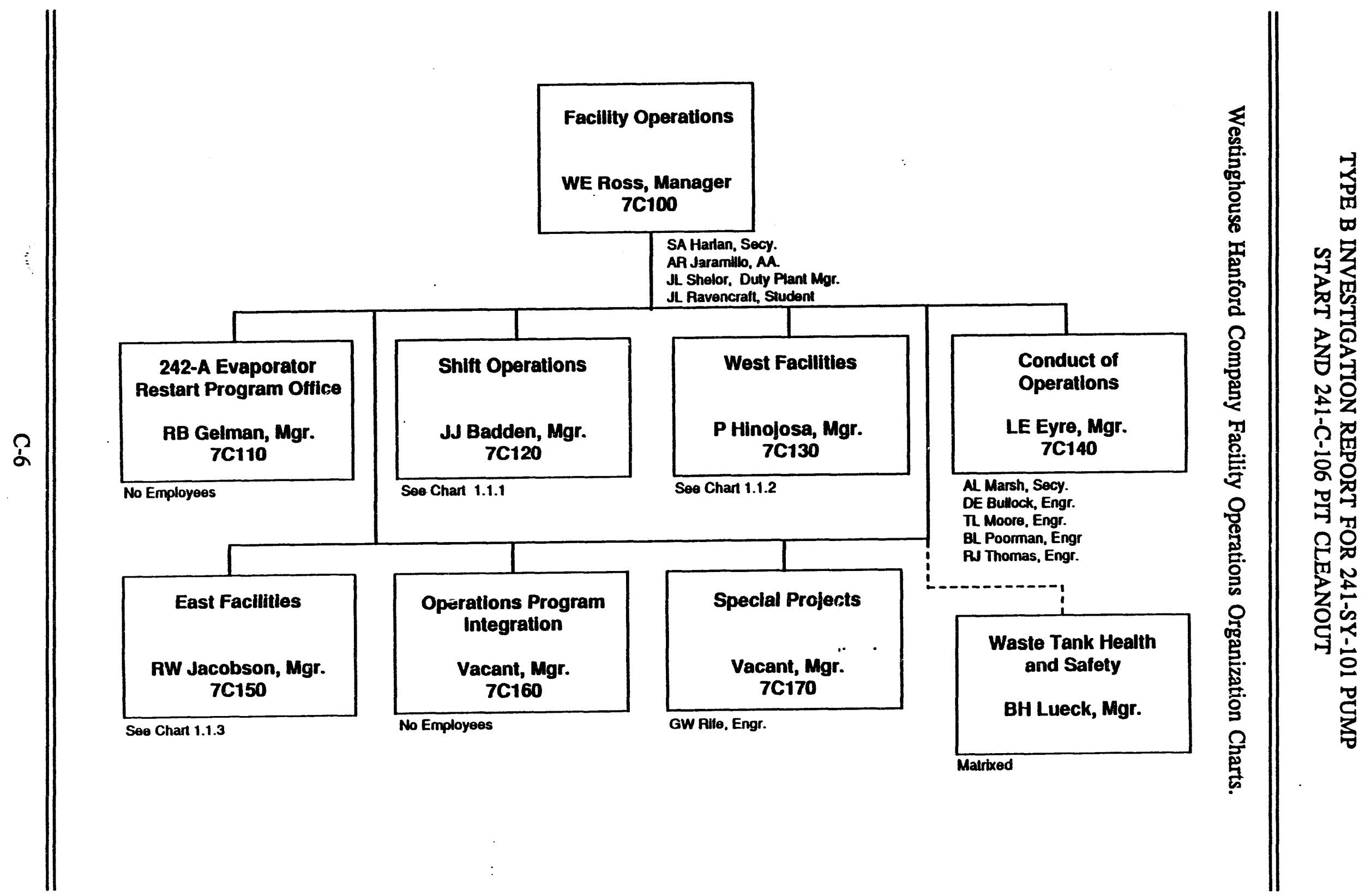




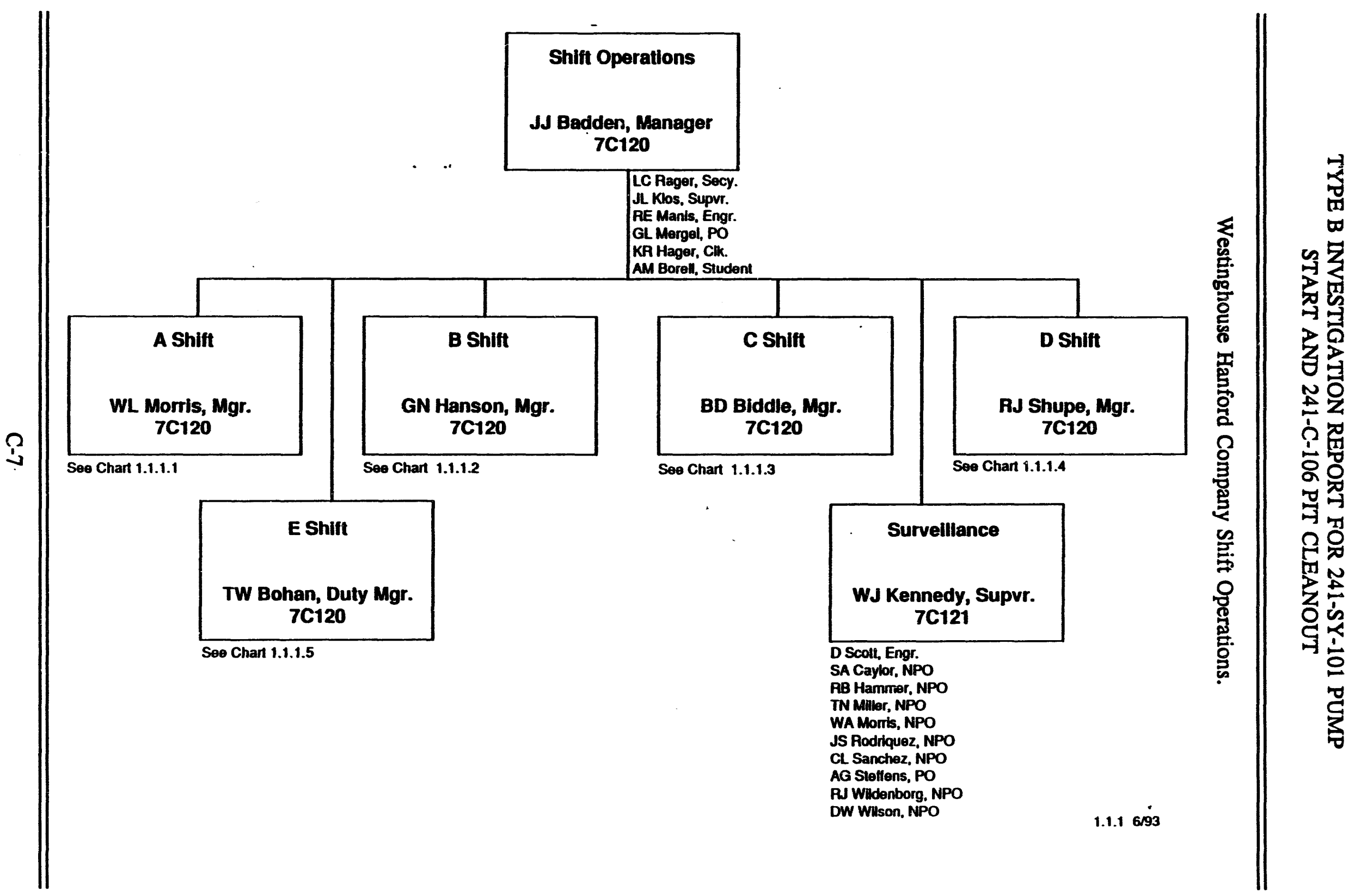




\section{TYPE B INVESTIGATION REPORT FOR 241-SY-101 PUMP \\ START AND 241-C-106 PIT CLEANOUT}

Westinghouse Hanford Company West Facilities.

\begin{tabular}{|c|c|c|}
\hline & $\begin{array}{c}\text { Wost Facillities } \\
\text { P Hinojosa, Manager } \\
76130\end{array}$ & \\
\hline & $\begin{array}{l}\text { LS Herres Secy. } \\
\text { SK Heinen, Clk. } \\
\text { MD Long, Engr. } \\
\text { JE Perham, Engr. } \\
\text { GJ Rust, Engr. } \\
\text { MJ Armstrong, NO } \\
\text { DO Dudtey, NPO } \\
\text { HF Emerson, NPO } \\
\text { VM Merkt, NPO } \\
\text { JD Gridley, Clk. } \\
\text { DK Krause, Clk. } \\
\text { HS_Honrolh_Sluden }\end{array}$ & \\
\hline S/T/U Complex & Isolation/Stabilization & Core Sampling \\
\hline $\begin{array}{c}\text { DE Badt, Mgr. } \\
7 \mathrm{C13t}\end{array}$ & $\begin{array}{c}\text { KE Myers, Mgr. } \\
7 \text { C132 }\end{array}$ & $\begin{array}{c}\text { JS Lee, Mgr. } \\
\text { 7C133 }\end{array}$ \\
\hline $\begin{array}{l}\text { JL Ahrens, Engr. } \\
\text { BL Hall Jr., Engr. } \\
\text { BC Campbell, NPO } \\
\text { J Guerra, NPO } \\
\text { TA Klute, NPO } \\
\text { RE Rogers, NPO } \\
\text { DL Witherspoon, NPO } \\
\text { YM Hullman, NO }\end{array}$ & $\begin{array}{l}\text { MN Johnson, Engr. } \\
\text { CW Peoples, Engr. } \\
\text { TE Brighilon, NPO } \\
\text { SR Davis, NPO } \\
\text { RA Friesz Jr., NPO } \\
\text { SA Ham-Huebner, NPO } \\
\text { LK Kelly, NO } \\
\text { DA Klug, NO } \\
\text { JA Payne, NPO } \\
\text { GJ Sullivan, NO } \\
\text { WR Taylor, NO } \\
\text { DS Todish, NPO } \\
\text { JL. Tucksen, NPO }\end{array}$ & $\begin{array}{l}\text { W Austln, Engr. } \\
\text { DC Hartley, Engr. } \\
\text { MC Jones, Engr. } \\
\text { MR Chunn, NPO } \\
\text { MJ Davis, NPO } \\
\text { LL Dean, NPO } \\
\text { RP Ekstrom, NPO } \\
\text { PA Kalsel, NPO }\end{array}$ \\
\hline
\end{tabular}




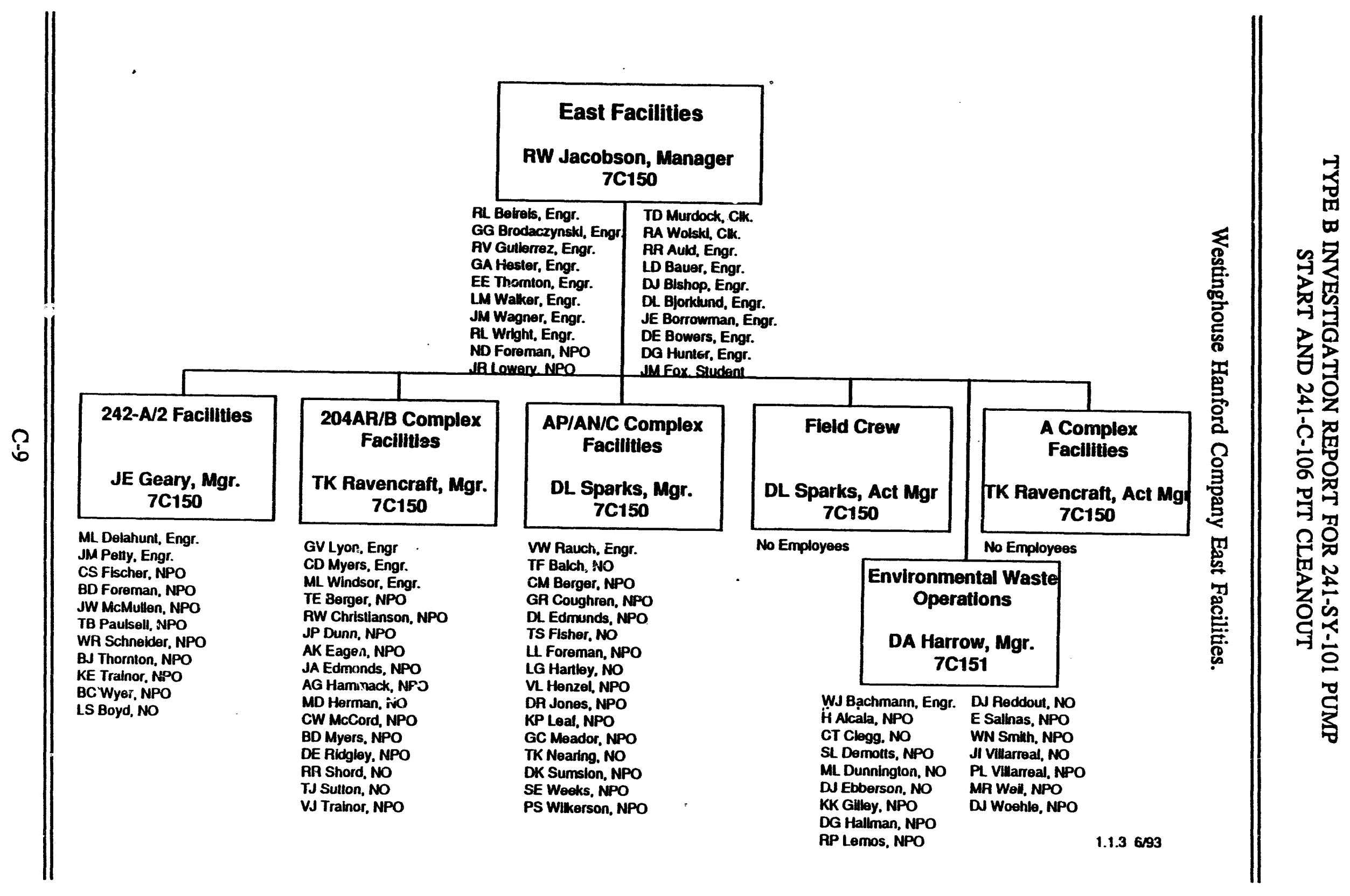


TYPE B INVESTIGATION REPORT FOR 241-SY-101 PUMP

START AND 241-C-106 PIT CLEANOUT

Westinghouse Hanford Company Waste Tank Maintenance.

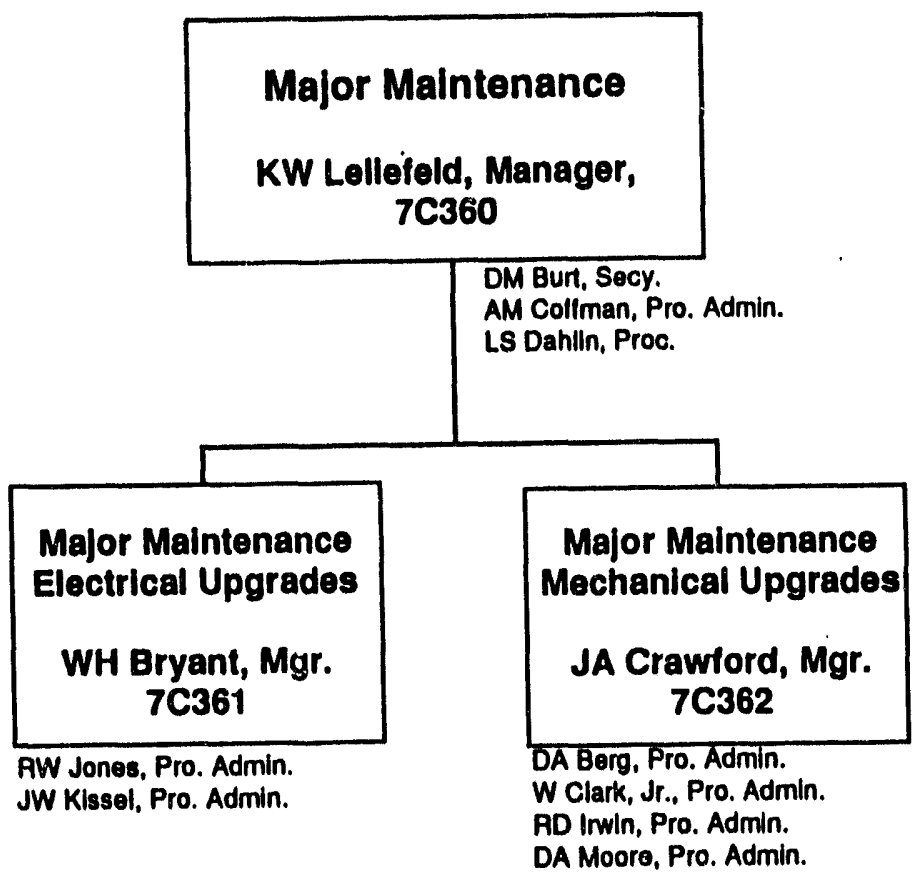


TYPE B INVESTIGATION REPORT FOR 241-SY-101 PUMP

START AND 241-C-106 PIT CLEANOUT

Westinghouse Hanford Company Major Maintenance.

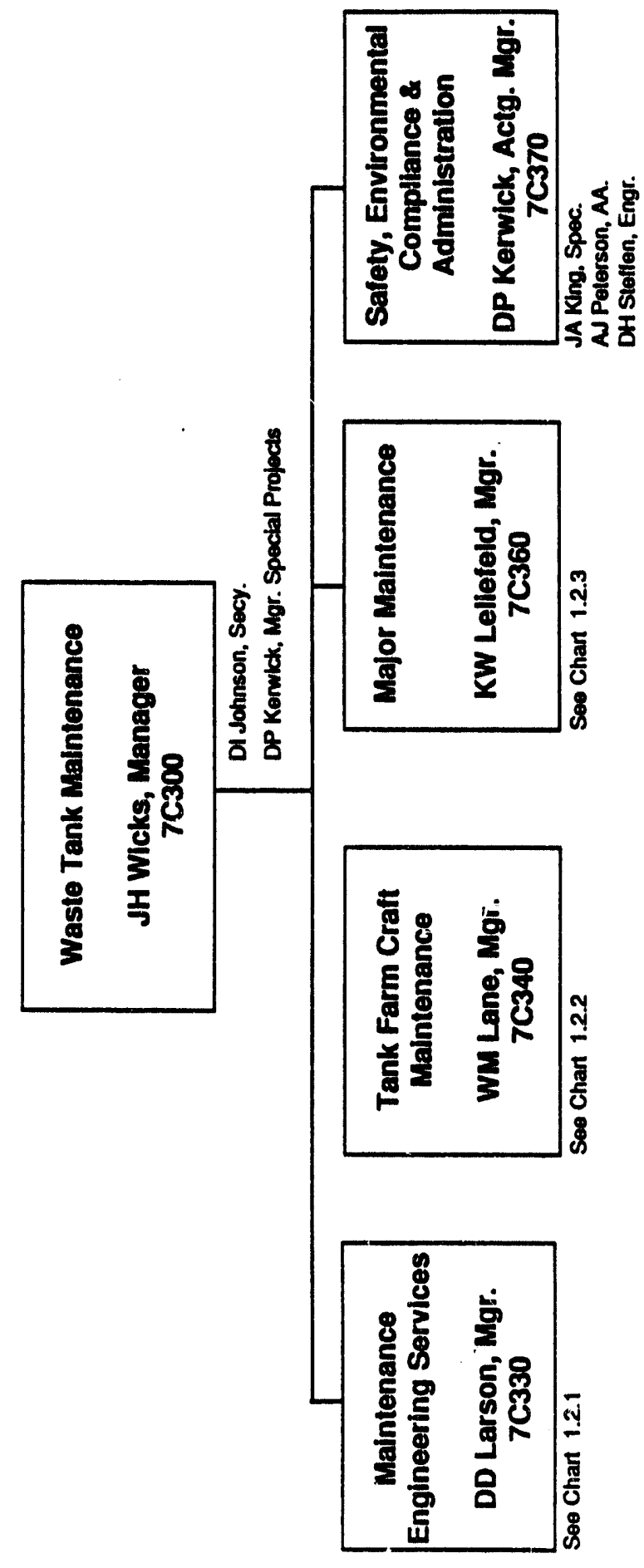


TYPE B INVESTIGATION REPORT FOR 241-SY-101 PUMP

START AND 241-C-106 PIT CLEANOUT

Westinghouse Hanford Plant Engineering.

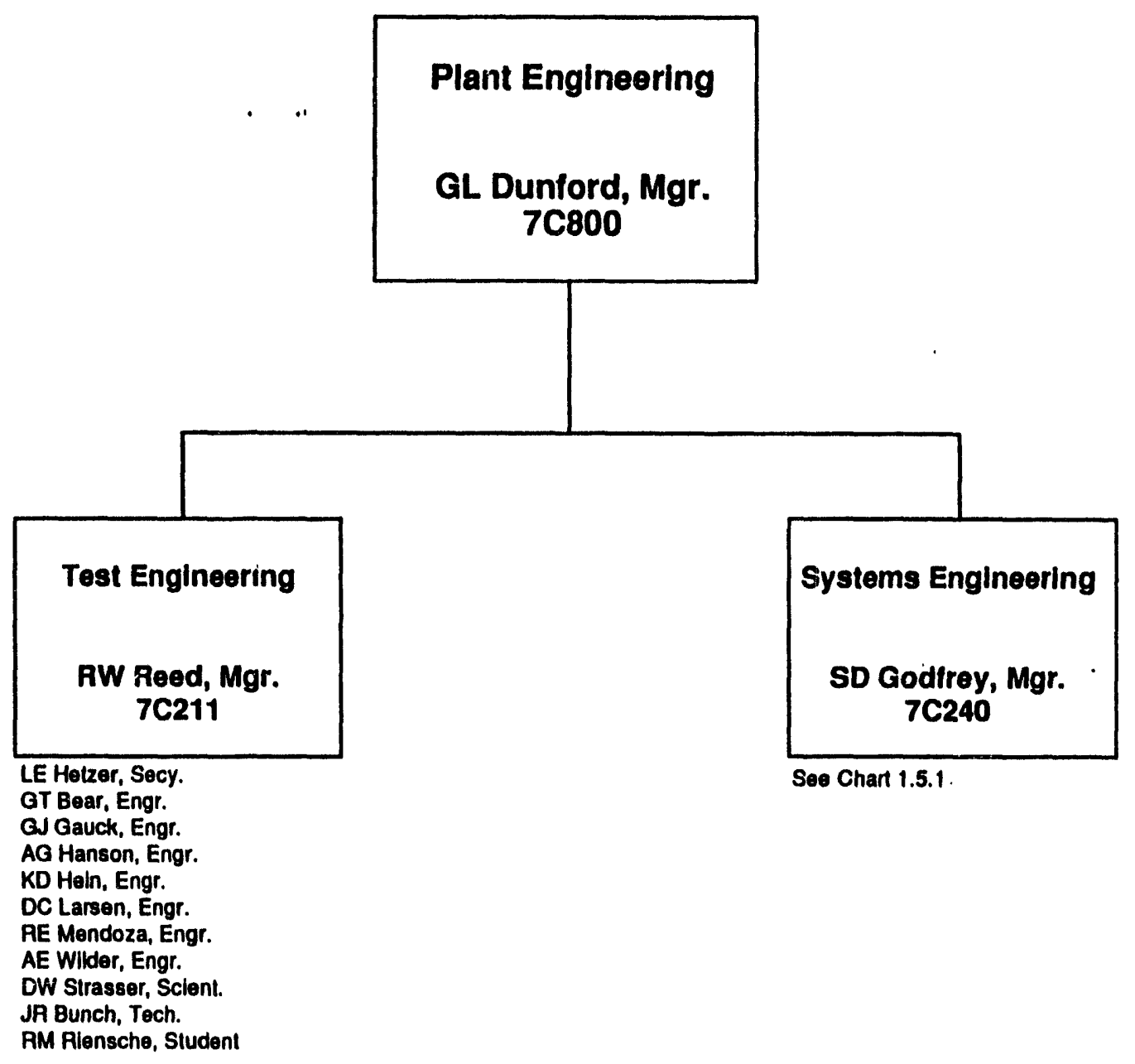




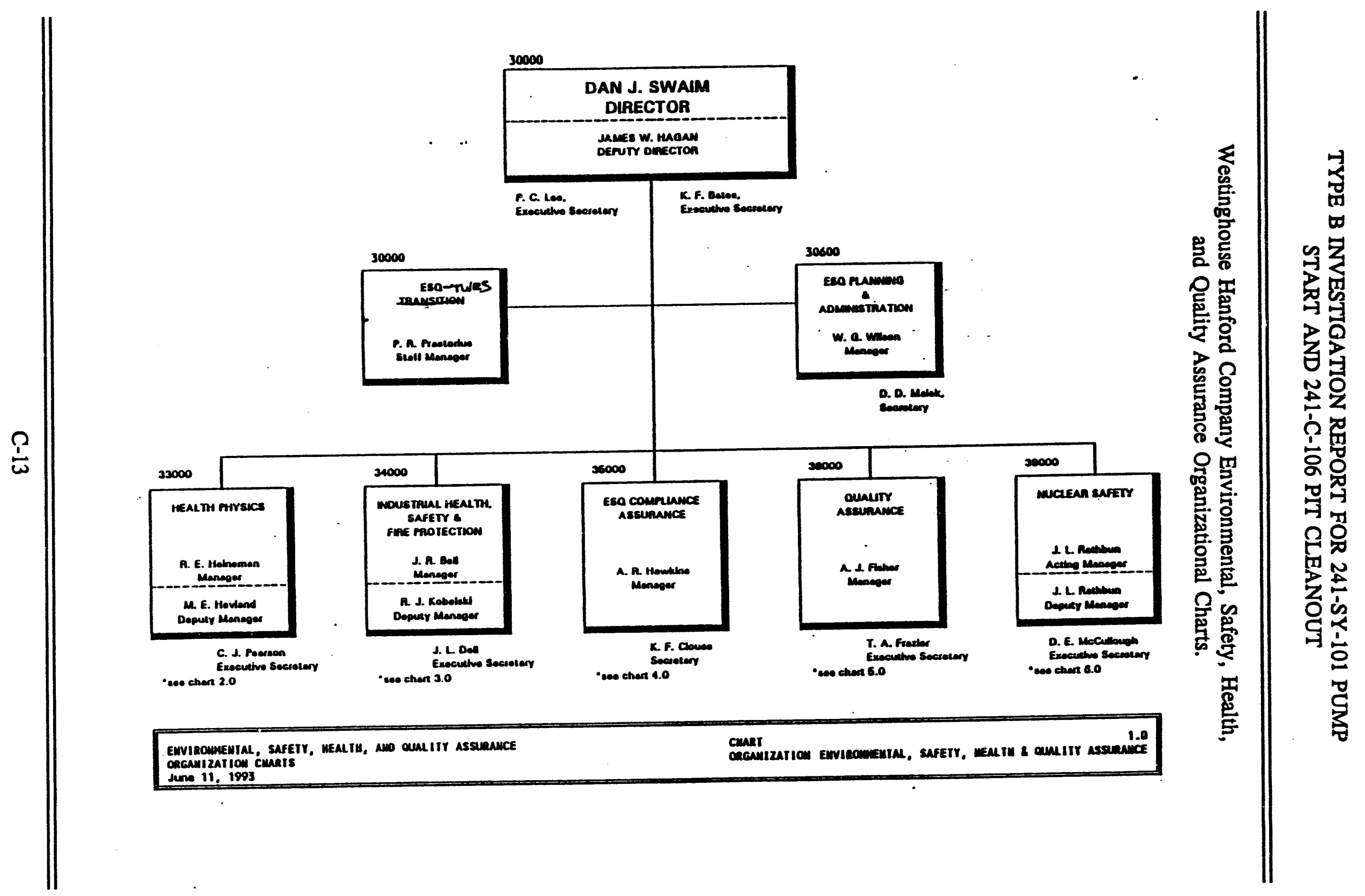




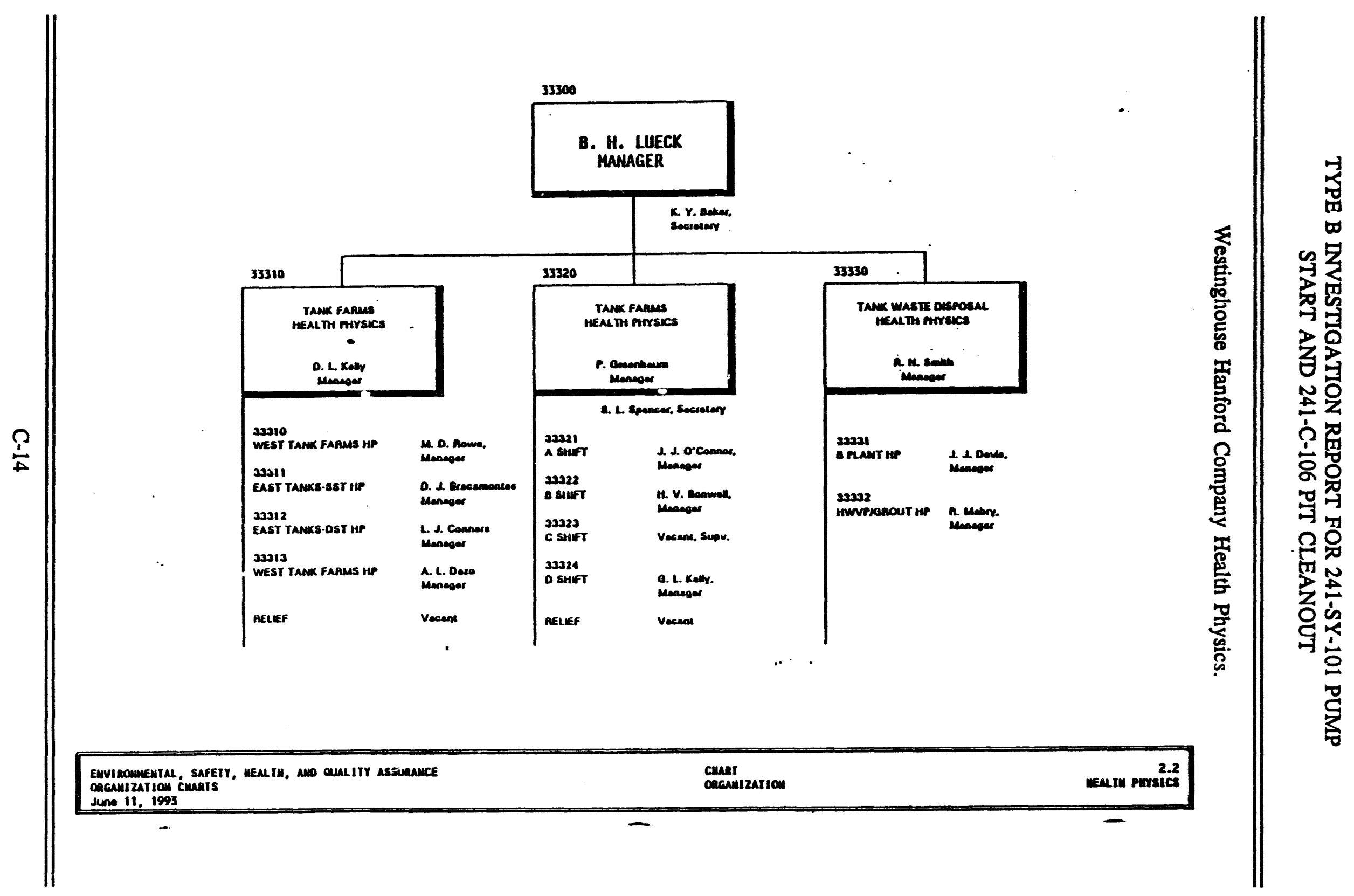




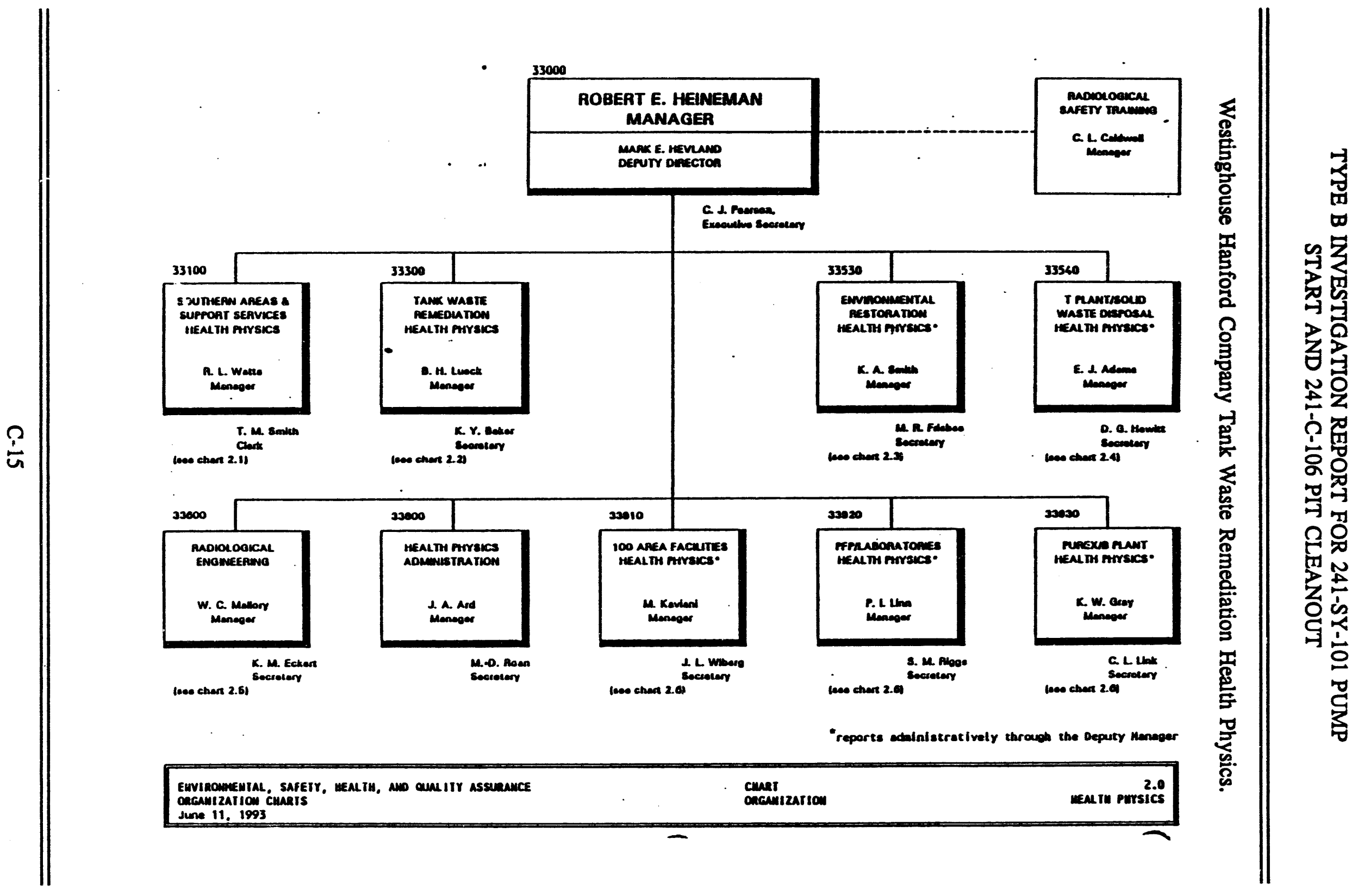



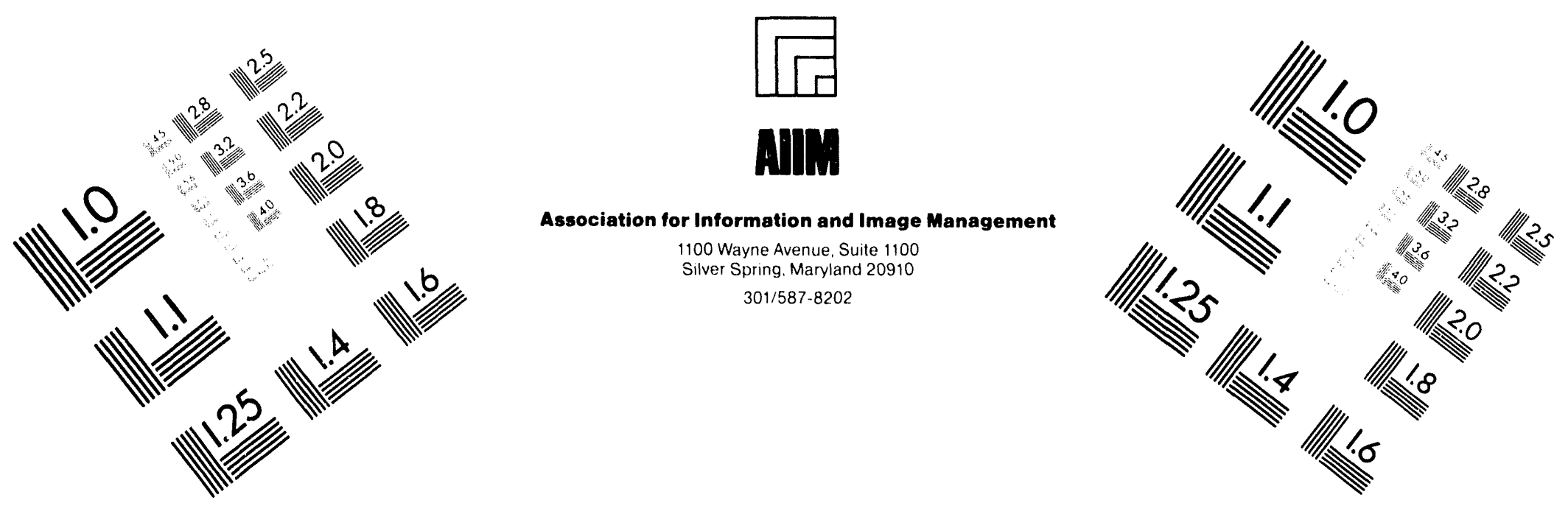

\section{Centimeter}

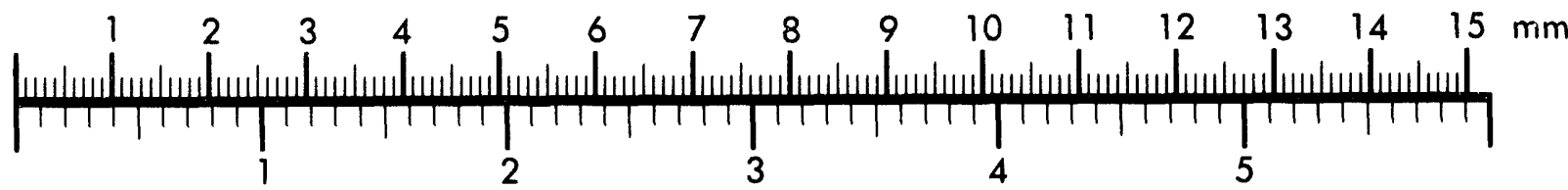
Inches
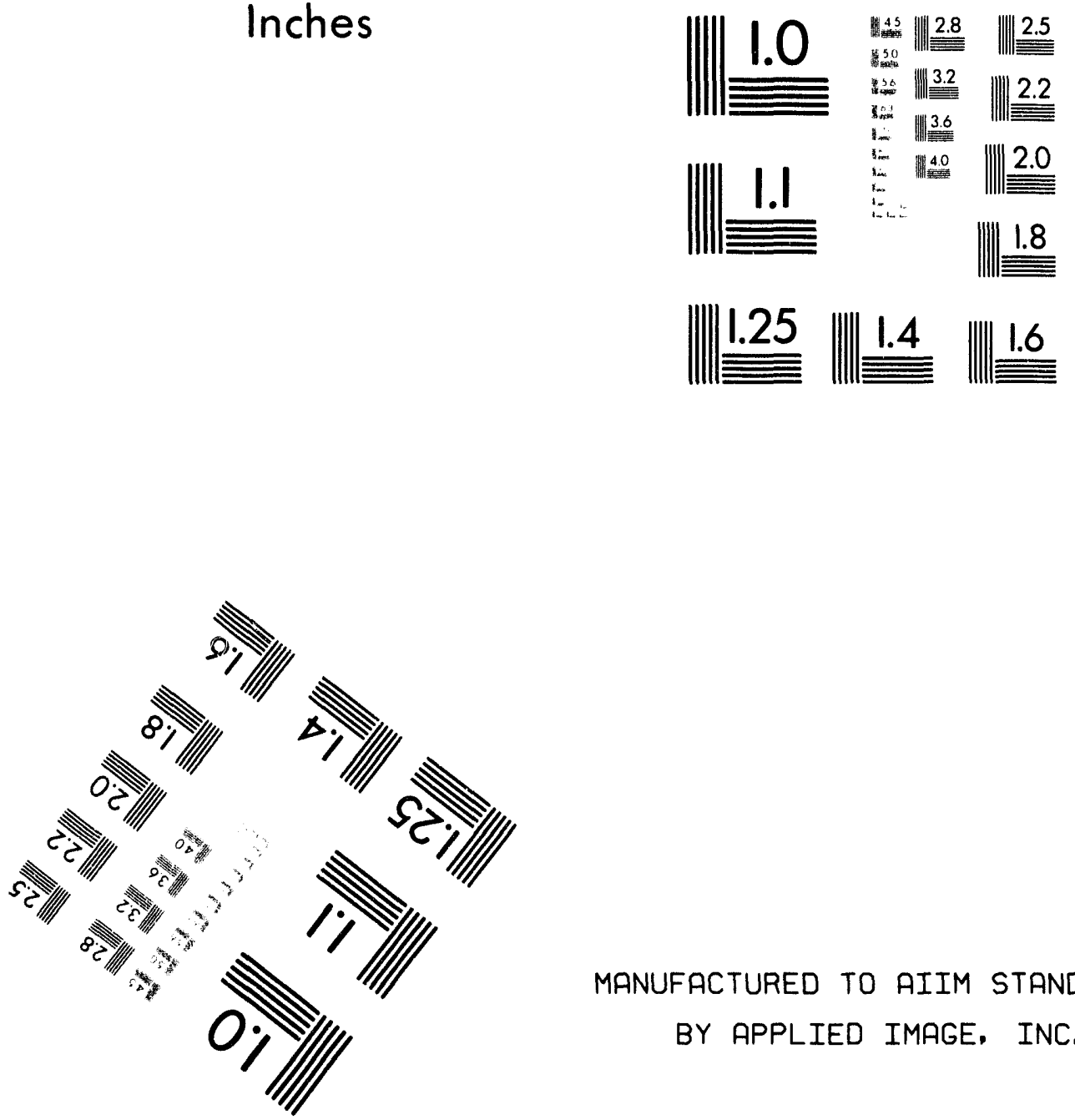

MANUFACTURED TO AIIM STANDARDS

BY APPLIED IMAGE, INC.

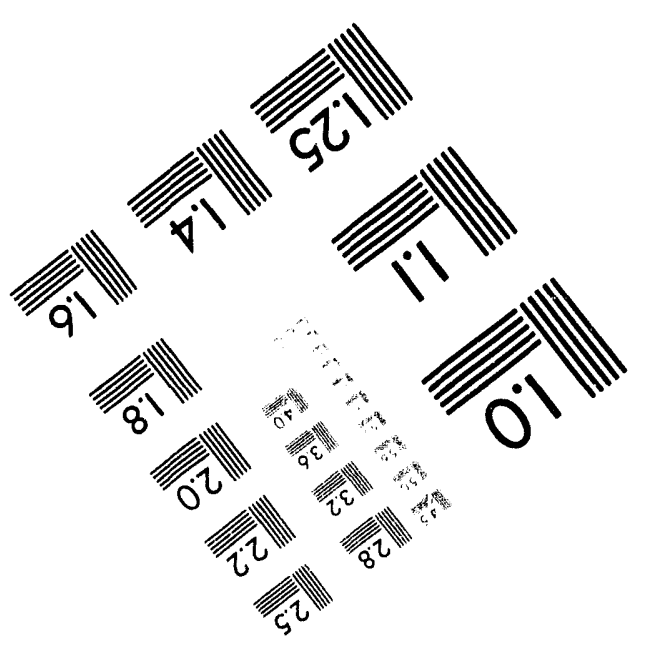



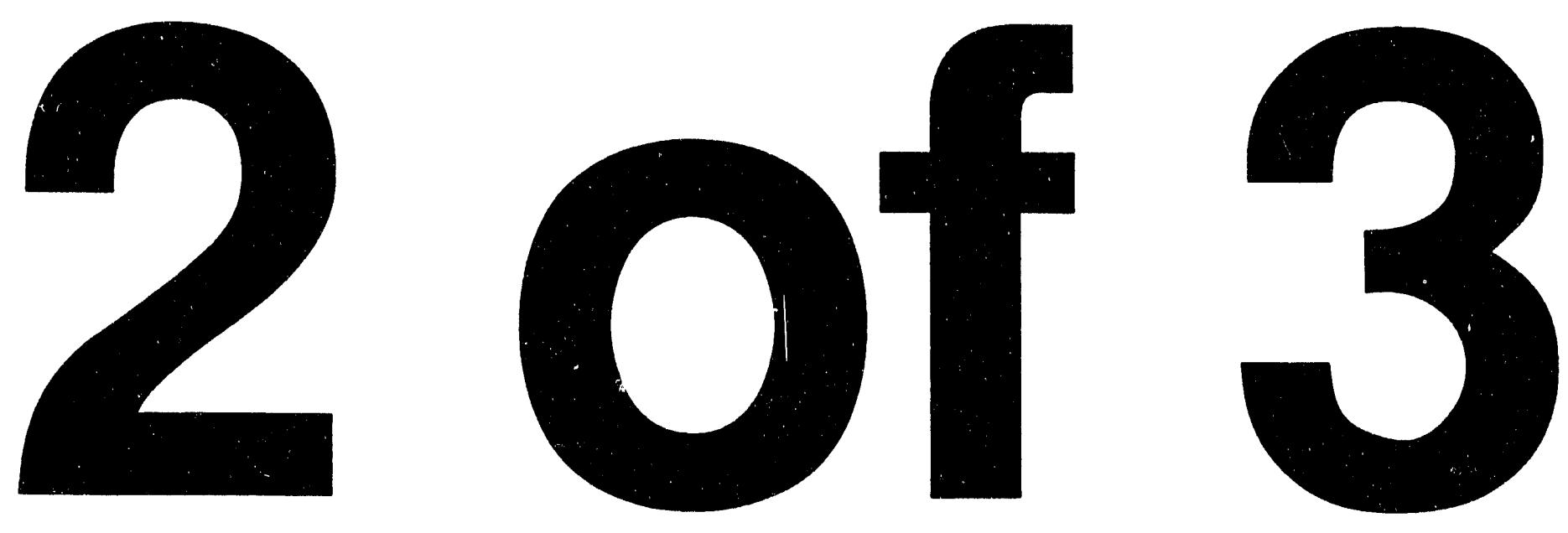


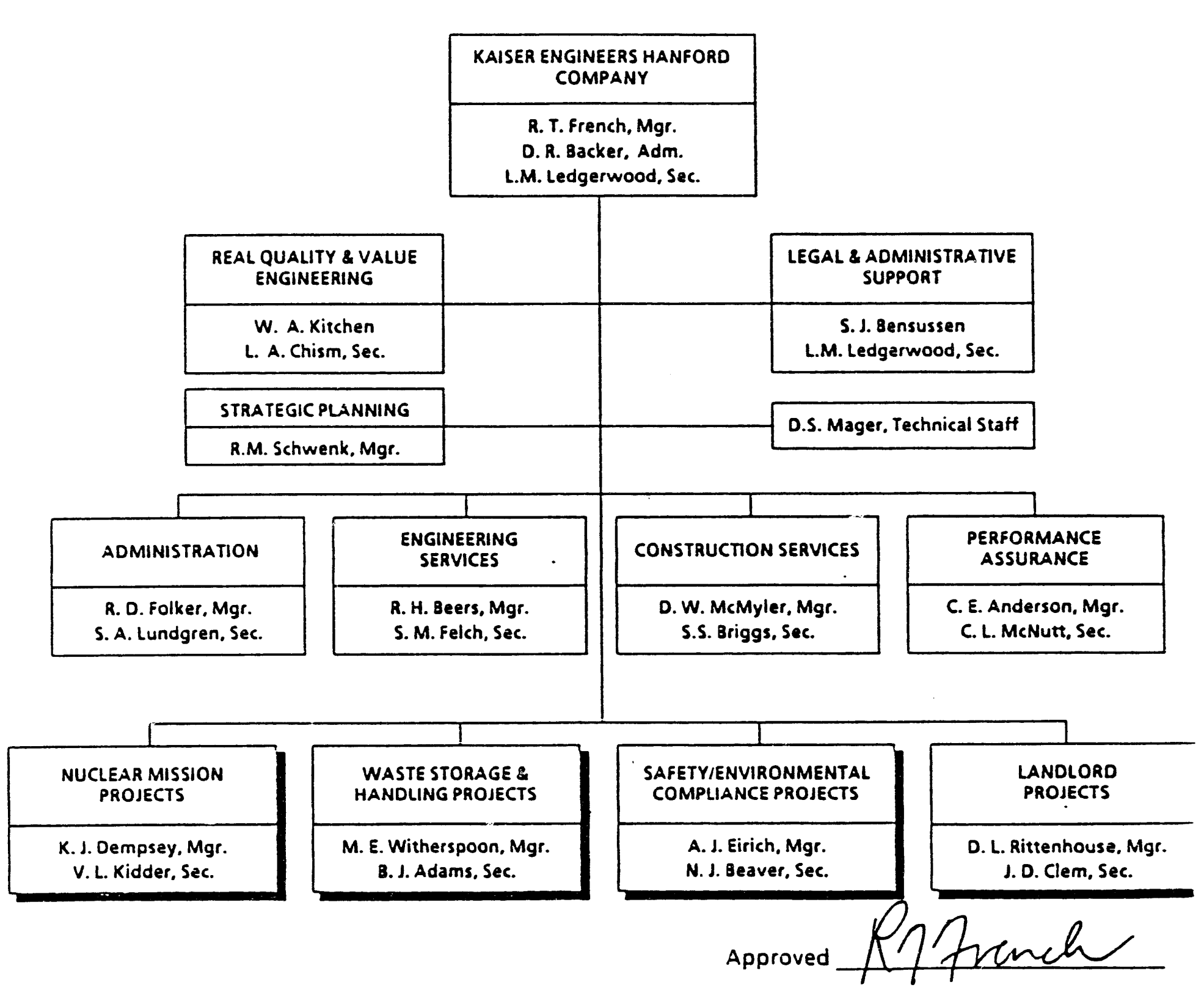




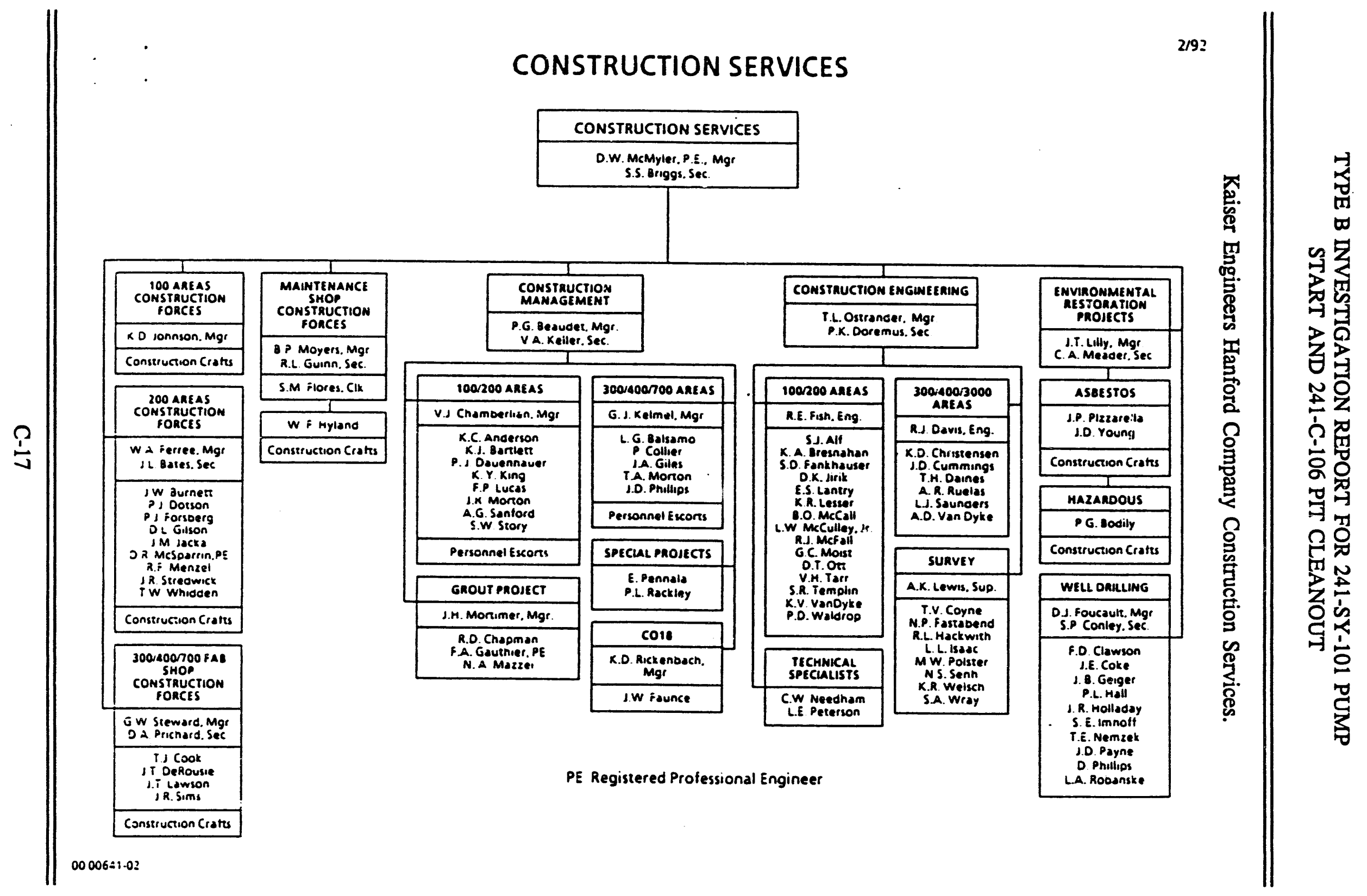


TYPE B INVESTIGATION REPORT FOR 241-SY-101 PUMP

START AND 241-C-106 PIT CLEANOUT

This page intentionally left blank.

C-18 
TYPE B INVESTIGATION REPORT FOR 241-SY-101 PUMP

START AND 241-C-106 PIT CLEANOUT

APPENDIX D

INTERVIEWEES

D-1 
This page intentionally left blank. 


\section{LIST OF INTERVIEWEES}

Westinghouse Hanford Company

$\begin{array}{ll}\text { Jeff Andrews } & \\ \text { John Bell } & \text { Don Hart } \\ \text { David Berg } & \text { Bob Heineman } \\ \text { B. Biddle } & \text { Vern Henzel } \\ \text { John Bloom } & \text { Omar Jaka } \\ \text { Tim Bohan } & \text { J. Jeskey } \\ \text { Bob Bartmettlor } & \text { B. Joyce } \\ \text { K. Bonewell } & \text { Don Kelley } \\ \text { Sonny Bracamontes } & \text { Dennis Kerwick } \\ \text { R. Brooks } & \text { William (Mike) Lane } \\ \text { Wayne Brule } & \text { Ronald L. Legg } \\ \text { Bill Bryant } & \text { Ken Leliefeld } \\ \text { Jeff Carlson } & \text { Bernie Lueck } \\ \text { Bill Clark } & \text { L. Marlin } \\ \text { Gordon Coughren } & \text { Jake McMullen } \\ \text { J. A. Crawffrd } & \text { Denny Newland } \\ \text { Gary Dunford } & \text { W. Parnell } \\ \text { Larry Eyre } & \text { J. Parrott } \\ \text { Cheryl Fischer } & \text { Dave Reber } \\ \text { T. Fisher } & \text { J. Shelor } \\ \text { C. Fricker } & \text { Royal Shupe } \\ \text { Rod Garrett } & \text { S. Stewart } \\ \text { C. Geier } & \text { David Tubbs } \\ \text { Bob Gelman } & \text { Det Wegener } \\ \text { D. Gordon } & \text { M. Wells } \\ \text { Kevin Hagerty } & \text { Bob Wininger } \\ \text { Doug Hamrick } & \text { Stephen Youngerman }\end{array}$

Kaiser Engineers Hanford

Jack Blessing

Jim Cockrum

Bill Stewart

Rich Root

John Stredwick

Laborer Union Representatives

Mark Reavis

Tom Reynolds 
TYPE B INVESTIGATION REPORT FOR 241-SY-101 PUMP

START AND 241-C-106 PIT CLEANOUT

This page intentionally left blank. 
TYPE B INVESTIGATION REPORT FOR 241-SY-101 PUMP START AND 241-C-106 PIT CLEANOUT

\section{APPENDIX E}

NEWS RELEASES 
TYPE B INVESTIGATION REPORT FOR 241-SY-101 PUMP

START AND 241-C-106 PIT CLEANOUT

This page intentionally left blank. 


\begin{tabular}{lr}
\hline (2) Westinghouse \\
Hanford Company
\end{tabular}$\quad \begin{array}{r}\text { News } \\
\text { Information }\end{array}$

Media Relations

P O Box 1970

Richland, WA 99352

(509) 376.5101

CONTACT: Craig Kuhiman

(509) 376-6826

FOR IMMEDIATE RELEASE

\section{SAFETY CONCERNS HALT MON-ESSENTIAL WORK IN HANFORD TANK FARMS}

Richland, Mash., Aug. 12, 1993 -- Westinghouse Hanford Company, the management and operations contractor at the U.S. Department of Energy's (DOE) Hanford Site, today halted all non-essential work at the Site's waste tank farms because of safety and operations concerns brought about by a series of recent incidents.

Westinghouse Hanford Executive Vice President William Alumkal, who manages the Tank Waste Remediation System at Hanford, announced his decision this afternoon following two recent incidents that show serious deficiencies in safety discipline, conduct of operations and personal accountability.

Alumkal called the two incidents "absolutely unacceptable." The first occurred last week when the mixer pump at Tank 101-SY was inadvertently started during a system test. Another incident happened Tuesday, August 10, when a Kaiser Engineers Hanford employee, acting on his own, taped a rock to a rope and lowered it through an open pipe into a waste tank to see if the pipe was plugged. The employee's hands and clothing were contaminated. In both cases, disciplinary action is being taken.

"Safety is and must be the top priority at Hanford, "Alumkal said. "These incidents demonstrate to me that our workforce is seriously deficient in its regard for safety and accountability in performing work in the tank farms.

"Consequentiy, we are going back to basics. We will not resume work until our managers, supervisors, and operators are retrained and we have determined conclusively that we can conduct our activities safely and effectively. This involves every level of our organization and every category of employee."

-more- 
Safety Concerns Halt Non-Essentlal Hork in Hanford Tank Farms (Add one)

Essential activities required for safety, monitoring and regulatory compliance will continue. The twice dally starting of the 101-sy mixer pump will continue with rigorous attention to safe operations to prevent tank waste from plugging the pump nozzles.

WHC-9308-101.TNK 


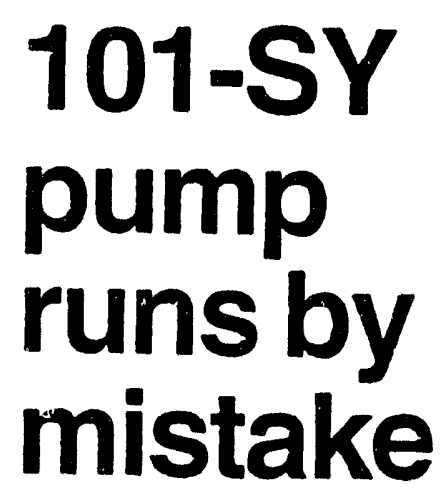

A giant mixer pump inside Han. ford's most dangerous high-level ra. dloactive waste tank was accidental. ly turned on Wednesday afternoon.

The incident happened at 3:15 p.m. while two creivs of workers were at Tank 101-SY, but Westinghouse Han. ford Co. did not issue a public state. ment about the incident until 5:30 p.m. Friday.

On Thursday: Westinghouse for. mally reported the accident to the Department of Enerzs and estab. lished an independent review team to examine the incident. company spokesman Craig Kuhlman said.

He said the accident apparently. happened while one crew of tvorkers was preparing to turn the pump on for a test as another crew was preparing to test some computer sontware. A worker on one leam opened the circuit breaker. but a worker on the other team then closed the switch and started the pump.

The pump ran for 30 seconds be. fore it was tumed ofr. Kuhlman said. He said there was no release of hy. drogen gas during the incident. and there was no damage to the pump or the waste tank

The massive pump ivas recently. installed in the tank to prevent the buildup of the potentially explosice gas. which has resulted in periodic "burps" as hydrogen is released.

Westinghouse on Thursday de clared an "unusual occurrence", the second-highest of three levels of severity that are assigned to nuclear. related incidents. The highest level would be an emerzency.

Computer software testing has been put on hold until the indepen. dent review of the incident is fin. ished. Kuhlman said. . Ill other test. ing at the 1 million-gallon under. ground storage tank will continue as scheduled. he said.

\author{
TRI-CITY HERALD \\ Tri-Cities, WA \\ Aúg ? ? 1993
}




\section{Pump accidentally turned on at nuclear site in Hanford}

RICHLAND. Wash. - A pump designed to reduce dangerous gas buildups in a radioactive-waste tank at the Hanford Nuclear Reservation was accidentally turned on during a test.

The incident occurred at 3:15 p.m. Wednesday while two work crews were at Tank 101-SY. Westinghouse Hanford Co. reported it Thursday to the federal Department of Energy.

A review team will examine the incident, company spokesman Craig Kuhlman said. It did not issue a pub. lic statement about the incident until 5:30 p.m. Friday.

The accident apparently happened while one crew was preparing to turn on the mixing pump for a test as another crew was preparing to test some computer software. A worker on one team opened a circuit breaker. but a worker on the other team then closed the switch and started the pump.

The pump ran for 30 seconds betore it was turned otf. Kuhiman sald. No hydrogen gas ivas released and no damage occurred to the pump or the 1 million-gallon waste tank. he said.

The pump was recently installed :o prevent buildups of the potential. ly explosive gas. Such buildups have resulted in periodic "burps" as hy. drogen is released.

Westinghouse on Thursday de. clared an "unusual occurrence." the second-highest of three levels of severity that are assigned to nuclear. related incidents. The highest leve! would be an emergency.

Computer soitware testing has been put on hold until the incident is reviewed, Kuhlman said.

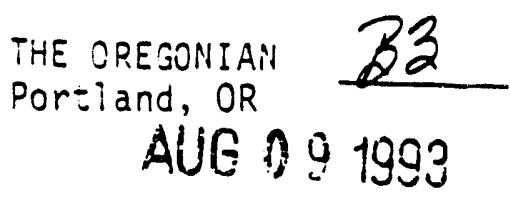


TYPE B INVESTIGATION REPORT FOR 241-SY-101 PUMP

START AND 241-C-106 PIT CLEANOUT

APPENDIX F

241-SY-101 DOCUMENTATION 
TYPE B INVESTIGATION REPORT FOR 241-SY-101 PUMP

START AND 241-C-106 PIT CLEANOUT

This page intentionally left blank. 
TYPE B INVESTIGATION REPORT FOR 241-SY-101 PUMP

START AND 241-C-106 PIT CLEANOUT

October 7, 1992

Page 1 of 1

\author{
Standing Order $\$ 92-47$ \\ Interface Understandings \\ Facllity Operations \\ 8 \\ 101-SY Test Engineers
}

See attached documentation (pages 1 through 3).

APPROVAL:

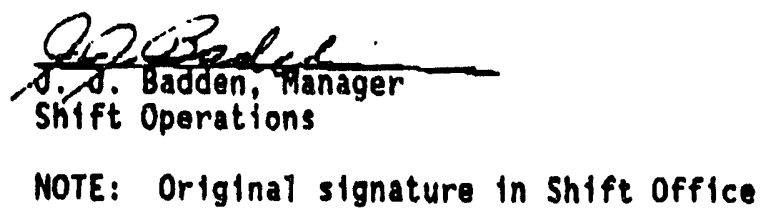


TYPE B INVESTIGATION REPORT FOR 241-SY-101 PUMP

START AND 241-C-106 PIT CLEANOUT

This page intentionally left blank. 
WASTE TANK REREDIATION SYSTEN

\section{STANOIME ORDERS}

Interface understandings botween Tank Farm Operations and 101-SY Remediation Test Engineers.

1. The Shlft Managers are the management authortty for Tank Farm Operatlons as well as the Butlding Emergency Director. As such the following applles:

a. The Shift Manager w111 conduct any notifications to DOE and management outside of the Test Engineer's immediate chain of command. The Test Engineers will notify the Shift Manager immediately of any events, first ald cases or off-normal condit tons.

b. The Test Englneers w111 recognize the authority of the Shift Manager to cause a termination of the test up to and including evacuation of the control tratier, local vicinity and/or the site. (PIans for shutting down the test to allow a "walk-away" should be in place.)

c. Performance of the mitigation test is conditional upon shife manager approval.

d. The orlginal test procedure document and any changes will be approved by Process Englneering (shift engineer) and Tank Farms Operations Shift Manager/Supervisor.

2. Whtle manning the control area for the 101-SY romediation pump, Test Englneers wtil be vlewed as an operating entity of Tank Farm Operations and therefore subject to Conduct of Operations practices and controls. e.g.:

a. A formal narrative logbook wtll be maintained in accordance with WHC-CM-5-7 Section 1.8

b. A formal shlft turnover will be conducted in accordance with WHC-CM-5-7 Section 1.6

c. A crew brtefing will be conducted with the Test Engineers and the TFO Shift Manager/Supervisor. The following, as a minimum, should be discussed:

The oncoming Test Engineers for each shift will call the Shift Supervisor before the start of their shift. They will inform him of the major events during the past shift, the anticlpated changes to the test conditions during the next shift, the names of the oncoming Test Engineers, and any other significant information. Two coples of the test plan will be provided to Shift Operation to ald status of progress, turnover and brtefings. 
d. The Test Enginoers will request pa'mlssion from the Shift Supervisor prlor to starting or restarting the mitigation test. Restarts would include starts after estabilished hold points in the test procedure and after unintended aborts. Restarts would not include pump activation after a shutdown as part of a normal cycling as established in the test procedure. (This information should be passed on at the shift briefing.)

e. The Test Engineers w111 promptly notlfy the West Shift Supervisor of any equipment fallure or signiflcant degradation resulting in unintentional abort (whether manual or DACS induced). The cause of the abort and its associated impact on testing shall be Identifled prior to resuming testing.

f. The Test Engineers will abort the test whenever they are directed to by the shift Supervisor. The Test Engineers will provide an explanation to the Mitigation Test Log.

g. The Test Engineers and of shift report w11l be delivered to the West Tank Farm Shift supervisor by the off going Test Engineers (If available).

3. The attached organization chart identifles shift interfaces by position and name.

Concurred:

C.Moltim 6 oct 92
Approved:

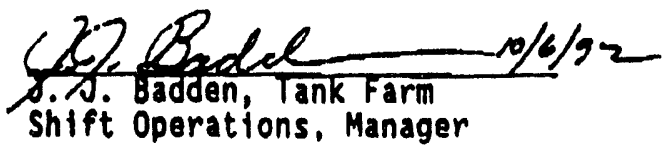


INTERFACE

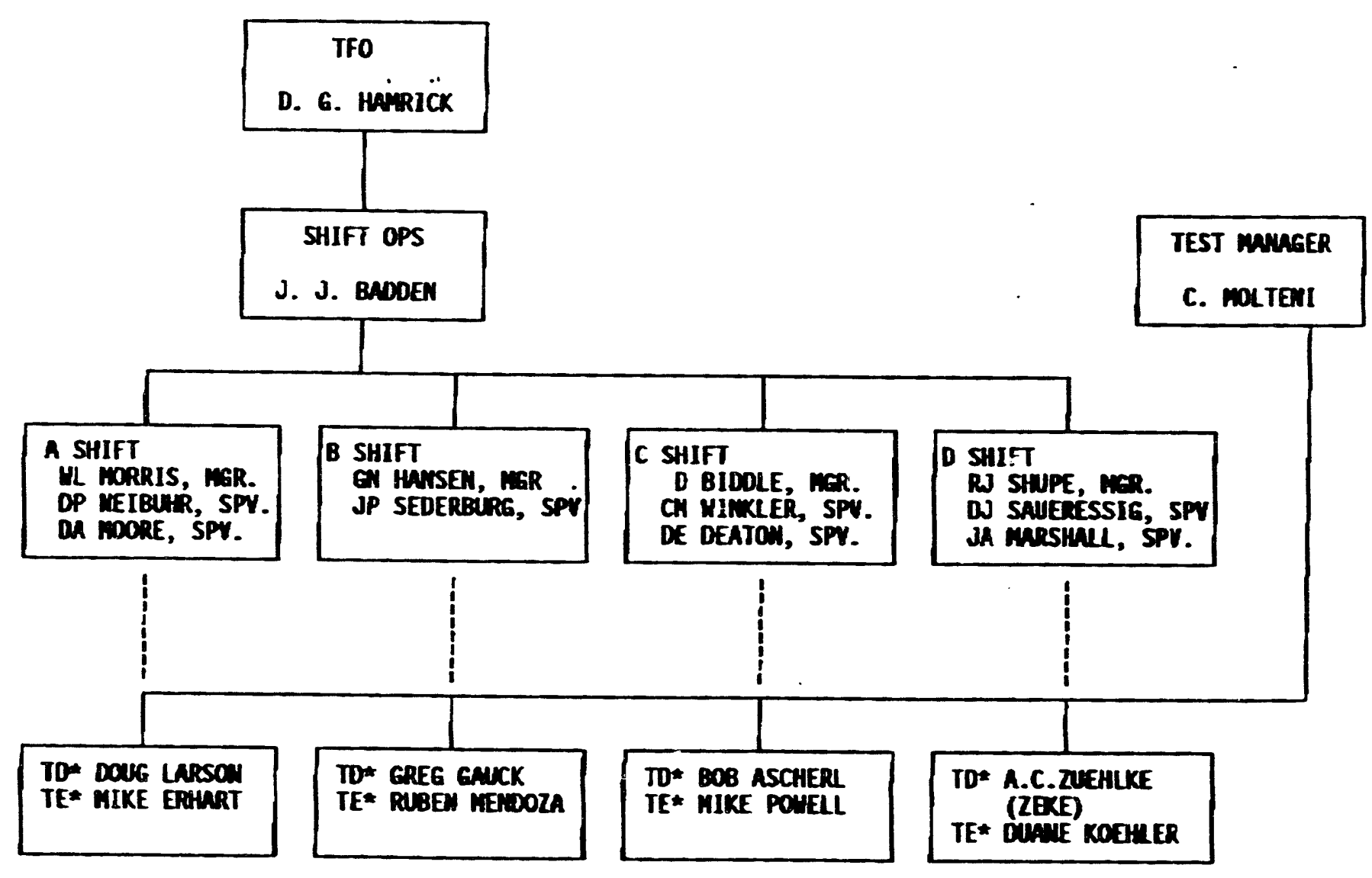


TYPE B INVESTIGATION REPORT FOR 241-SY-101 PUMP START AND 241-C-106 PIT CLEANOUT

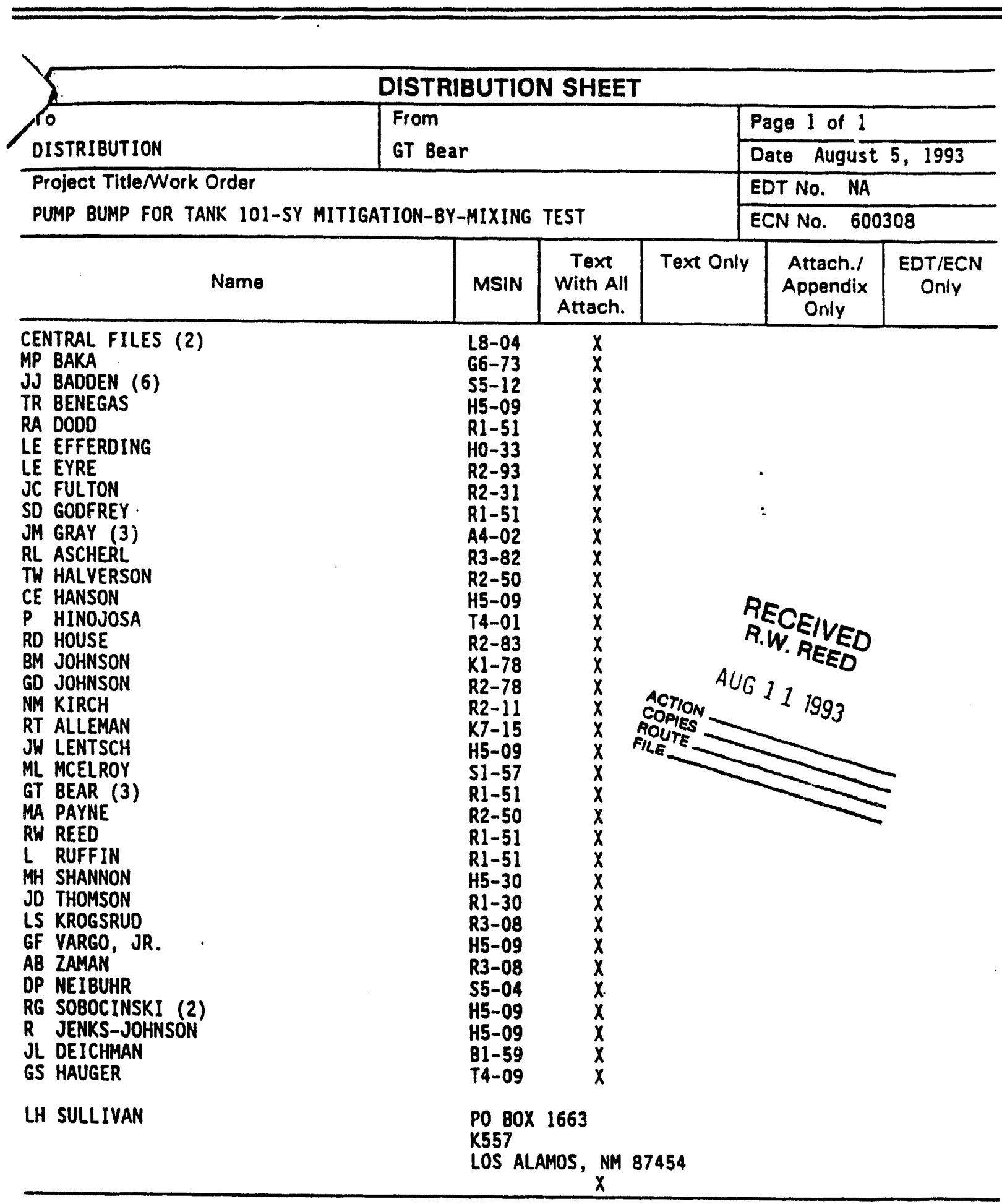


TYPE B INVESTIGATION REPORT FOR 241-SY-101 PUMP

START AND 241-C-106 PIT CLEANOUT

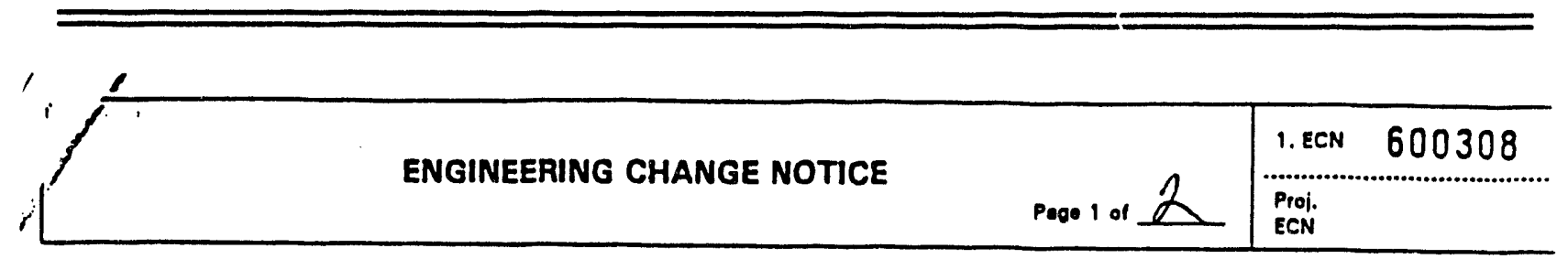

\begin{tabular}{|l|}
\hline 2. ECN Category (mark one) \\
Suppl omental
\end{tabular}

3. Originator's Meme, Organization, MSIN, and Telephone No.

GT BEAR, TEST ENGINEERING, RI-51, 373-4254

5. Project Title/No./Nork Order No.

HYDROGEN MITIGATION

8. Document Numbers Chenged by this ECN

(includes sheet no. and rev.)

\begin{tabular}{l|l|l} 
WHC-SD-WM-TPI-007, REV 0 & 600305,600310 \\
\hline
\end{tabular}

6. Iddg./Sys./Fac. No.

4. Date

August 2, 1993

11a. Modification Work

[] Yes (fill oue sik.

[X] No (na ilks. 11b.

ilc, ild)

No.

N/A

iic. Modification Work Complete

7. Impace Level

$25 Q$

10. Related po No.

, 600310

$N / A$

12. Deseription of chenge

Incorporates latest software changes, relocated steps related to orienting pump nozzles

into new Attachment $F$, included margin markings to identify steps referencing or

referenced by other procedures.

\begin{tabular}{|c|c|c|c|}
\hline $\begin{array}{l}\text { 13a. Justifleation } \\
\text { (mark one) }\end{array}$ & Criteris Change & visign inprovement & Envi rormental \\
\hline As-found & Facillitate Const. & Const. Error/Omission & Desion Error/Omission \\
\hline
\end{tabular}

16. Olatribution (include name, MSIM, and no. of copies)

See attached distribution sheet. 
TYPE B INVESTIGATION REPORT FOR 241-SY-101 PUMP

START AND 241-C-106 PIT CLEANOUT

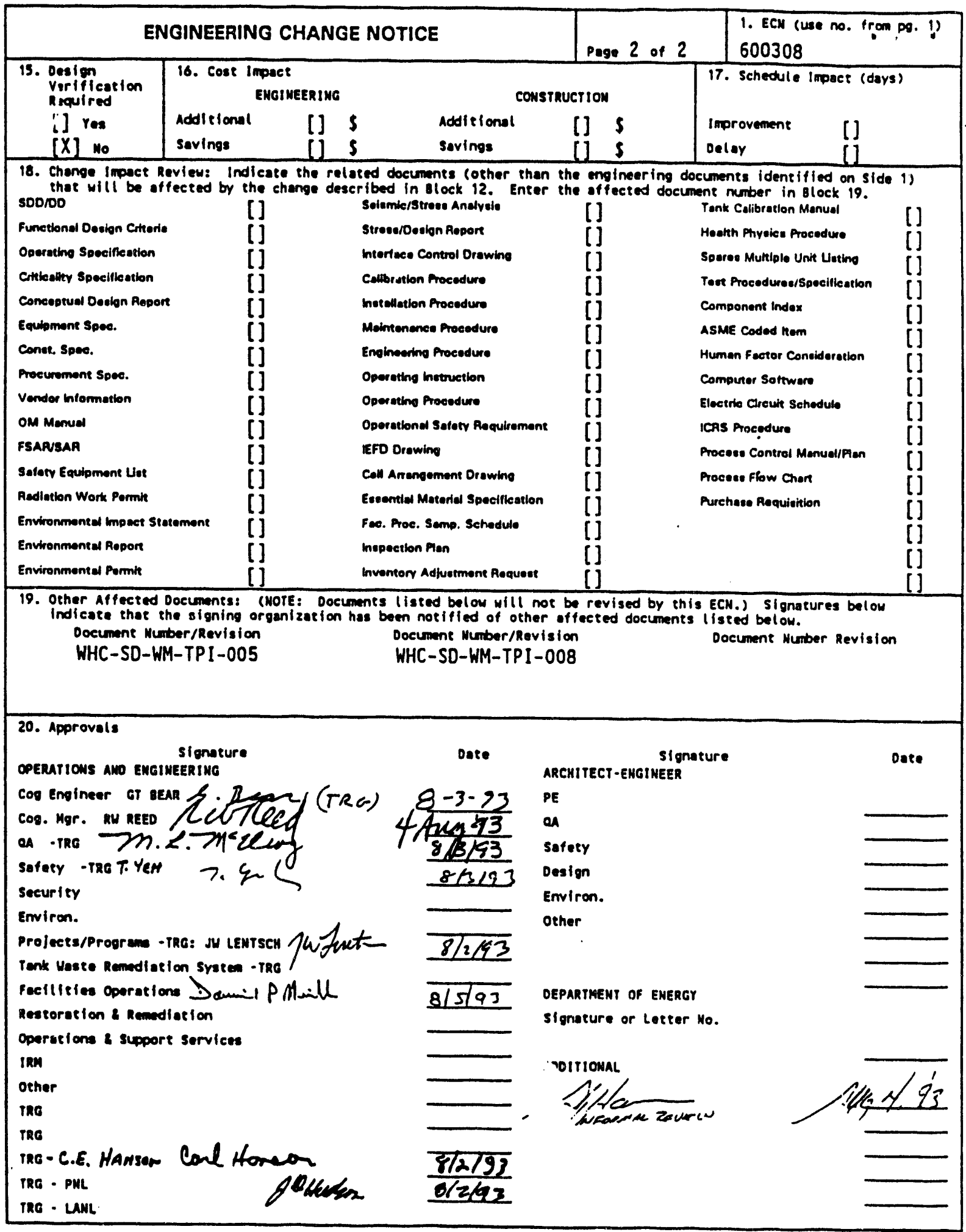


TYPE B INVESTIGATION REPORT FOR 241-SY-101 PUMP

START AND 241-C-106 PIT CLEANOUT

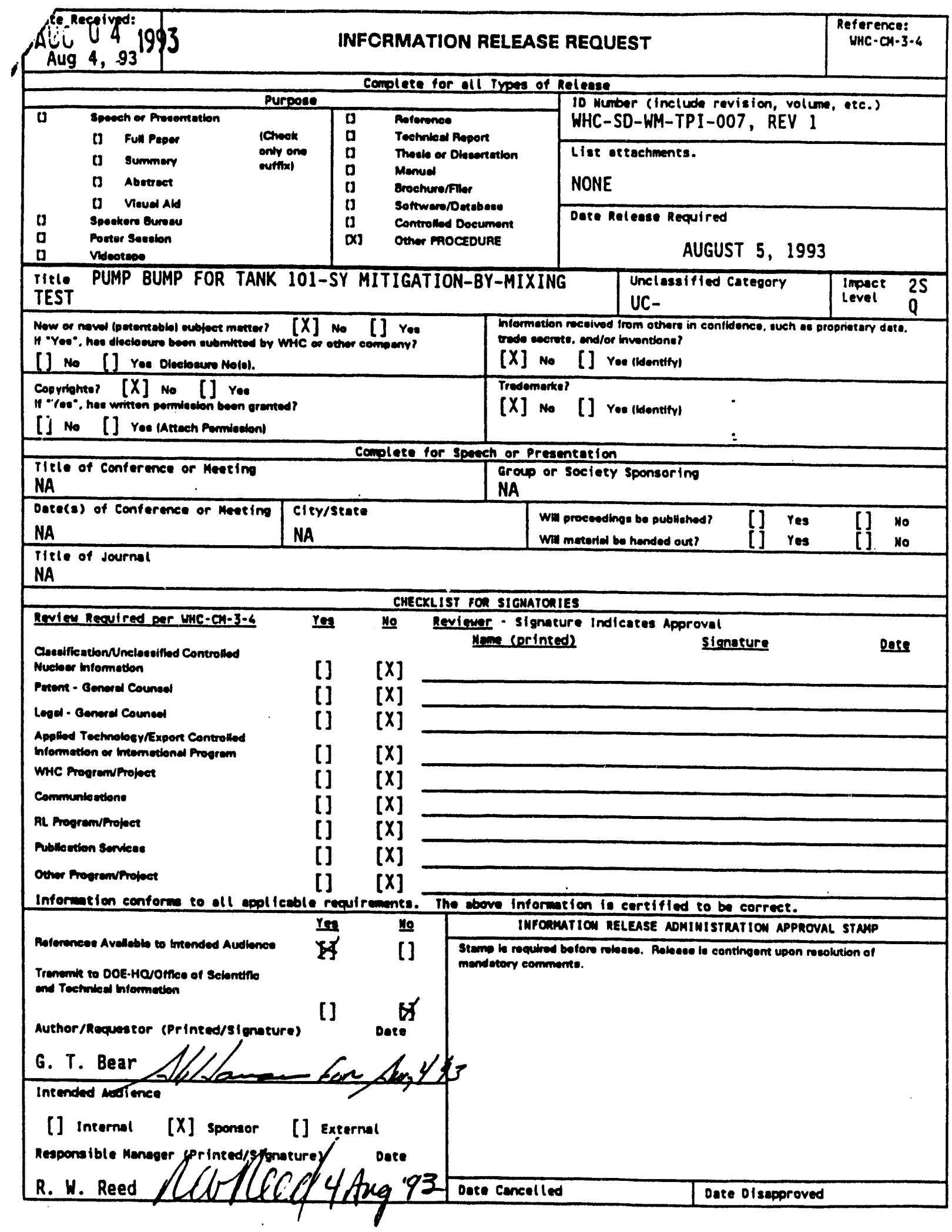




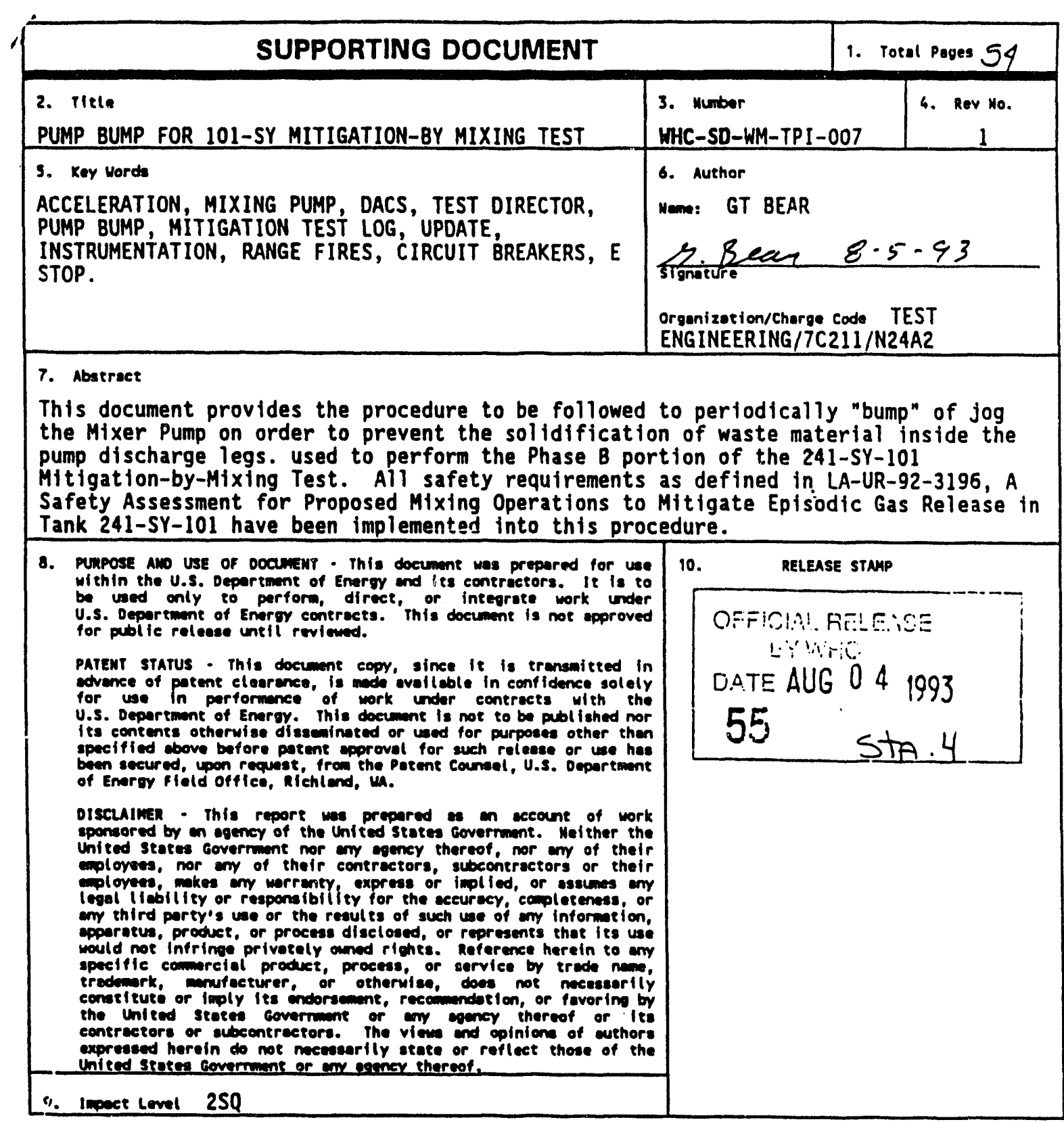



TYPE B INVESTIGATION REPORT FOR 241-SY-101 PUMP
START AND 241-C-106 PIT CLEANOUT

\begin{tabular}{|c|c|c|c|}
\hline 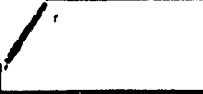 & RECORD OF REVISION & \multicolumn{2}{|c|}{$\begin{array}{l}\text { (1) Documene Munber } \\
\text { WHC-SO-WM-TPI-007 } \\
\text { Page 1 }\end{array}$} \\
\hline \multicolumn{4}{|c|}{$\begin{array}{l}\text { (2) IIEle } \\
\text { PUMP BUMP FOR TANK 101-SY MITIGATION-BY-MIXING TEST }\end{array}$} \\
\hline \multicolumn{4}{|c|}{ chance coursol atcono } \\
\hline (3) Revision & (4) Deseription of Chemen - Replece, ned, and Delete Pagen & \multicolumn{2}{|c|}{ Authorized for Releese } \\
\hline 0 & (7) NEH PROCEDURE & \begin{tabular}{|l} 
(5) Cog. Engr. \\
GT BEAR
\end{tabular} & \begin{tabular}{|l} 
(6) Cog. Har. Dete \\
Pu DFEn
\end{tabular} \\
\hline $1 R S$ & $\begin{array}{l}\text { All changes indicated with bars in LH } \\
\text { margin: incorp'd latest software } \\
\text { improvements; relocated steps for orienting } \\
\text { nozzles into new Att'mt F; included margin } \\
\text { markings to identffy steps that are } \\
\text { referenced by or make reference to steps in } \\
\text { other procedures - to aid in future } \\
\text { revisions. Pec eco- } 600308\end{array}$ & $\begin{array}{l}\text { GT BEAR } \\
S \cdot B \text { Can } \\
8-3-93\end{array}$ & $\begin{array}{l}\text { RW REED } \\
\text { Nelloed } \\
4 \text { Areg } 93\end{array}$ \\
\hline & & $:$ & \\
\hline & & & \\
\hline & . & & \\
\hline & & & \\
\hline & & & \\
\hline & & & \\
\hline & & & \\
\hline & & & \\
\hline & & & \\
\hline & & & \\
\hline & & & \\
\hline & & & \\
\hline & & & \\
\hline & & & \\
\hline & & & \\
\hline & & & \\
\hline & & & \\
\hline & & & \\
\hline & & & \\
\hline & & & \\
\hline & & & \\
\hline & & & \\
\hline & & & \\
\hline & & & \\
\hline & & & \\
\hline
\end{tabular}


This page intentionally left blank. 
TYPE B INVESTIGATION REPORT FOR 241-SY-101 PUMP

START AND 241-C-106 PIT CLEANOUT

PUMP BUMP

for

TANK 101-SY MITIGATION-BY-MIXING TEST

WHC-SD-WM-TPI-007

Rev. 1

August 2, 1993 
This page intentionally left blank. 
TYPE B INVESTIGATION REPORT FOR 241-SY-101 PUMP

START AND 241-C-106 PIT CLEANOUT

\section{TABLE OF CONTENTS}

1 TEST SUBJECT IDENTIFICATION . . . . . . . . . . . . . . . . . . . 1

2 GENERAL DESCRIPTION .......................... 1

2.1 Test Objective

2.2 Test Method

3 TEST CONDITION LIMITS .......................... 1

3.1 Pump Operation Limits

3.2 Abort Criteria

3.3 Precautions and Limitations

4 IMSTRUHENTS AND CALIBRATIOH .................... 3

5 FACILITIES, EqUIPMENT, AND MATERIALS .............. 3

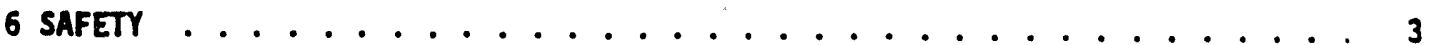

7 MAINTEMANCE AND faIluRES ................... 3

8 TEST DATA ............................. 4

9 PERSONNEL RequirenENTS ................... 4

10 MITHESSES ....................... 5

11 PROCEDURES .................................. 6

11.1 Pre-start Conditions $\ldots \ldots \ldots \ldots$

11.2 Pump Bump $\quad 8$

11.2.66 Exit MODSOFT 21

11.3 Tank Level Monitoring 25

11.4 General Shift Procedures and Requirements 25

12 DISPOSITION OF TEST SUBJECT . . . . . . . . . . . . . . . . . 25

13 REFEREHCES . . . . . . . . . . . . . . . . . . . . . 26

14 Procedure changes . . . . . . . . . . . . . . . . . . . . 27

15 DATA SHEETS . . . . . . . . . . . . . . . . 28

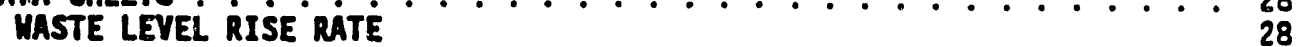

ATTACHAET A, Minimum Instrumentation Checklists . . . . . . . . . . . 29

Pump Bumping Instrumentation 30

ATTACHEET 8 . . . . . . . . . . . . . . . . . . . . 37 
TYPE B INVESTIGATION REPORT FOR 241-SY-101 PUMP

START AND 241-C-106 PIT CLEANOUT

PUMP BUMP

WHC.SD-WM-TPI-007

FOR

August 2, 1993

TANK 101-SY MITIGATION-BY-MIXING TEST Rev. 1

ATTACHAEN C . . . . . . . . . . . . . . . . . . . . . 38

Attachment D, PLC Abort Verffication . . . . . . . . . . . . . . 39

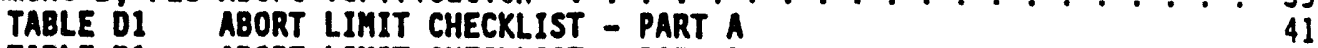

TABLE DI ABORT LIMIT CHECKLIST - PART B 42

Attachment E, Disabling Inoperable Instruments . . . . . . . . . . . . . 43

TABLE EI ABORT COIL CROSS REFERENCE $\cdots \cdots \cdots+\cdots \cdots$

Attachment F, Orienting the Mixer Pump Nozzles . . . . . . . . . . . . . . 49

Connent Snezt . . . . . . . . . . . . . . . . . . . . . . . . 50 


\section{TYPE B INVESTIGATION REPORT FOR 241-SY-101 PUMP START AND 241-C-106 PIT CLEANOUT}

PUMP BUMP

FOR

WHC-SD-WM-TPI-007

August 2, 1993

TANK 101-SY MITIGATION-BY-MIXING TEST

Rev. 1

\section{TEST SUBJECT IDENTIFICATION}

The operation of the 101-SY Mixer Pump for short periods of time is thought to maintain the downcomer legs and discharge nozzles free and clear of a potential waste sludge plug. It is intended that the 101-SY Mixer Pump will be operated at least once per day either by bumping, as described in this document or by testing, as described elsewhere.

\section{GEMERAL DESCRIPTION}

This procedure implements the applicable requirements of WHC-SD-WM-TP-140, TEST PLAN FOR TANK 101-SY MITIGATION-BY-MIXING TEST, PHASE A and .WHC-SD-WM-TP-153, PHASE B TEST PLAN FOR TANK 101-SY MITIGATION-BY-MIXING TEST referred to here in as the Phase $A$ Test $P 1$ an and Phase $B$ Test Plan, respectively. :

\subsection{Test objective}

The primary objective of this procedure is to mobilize a sufficient quantity of waste siudge in the downcomer legs and nozzles of the 101-SY Mixer Pump in order $t_{i}$ prevent the solidification of the waste to an extent that it forms a potential obstruction to the normal flow path of the pump.

\subsection{Test Method}

Subject to compliance with all applicable pre-requisites and requirements contained herein, the 101-SY Mixer Pump will be accelerated (or ramped up) at a rate not to exceed $100 \mathrm{rpm} /$ minute to a speed determined by the Iest Review Group (not to exceed $1000 \mathrm{rpm}$ ). The DACS will initiate a countdown timer from the time the pump has achieved full speed and automatically trip the pump at the end of the countdown.

During the performance of the bump, process parameters shall be monitored and compared with predetermined abort criteria. The bump shall be terminated should any of the abort criteria be met.

\section{TEST CONDITION LIMITS}

The requirements given in Sections $3.1,3.2$, and 3.3 below shall be met prior to and during pump bumping.

\subsection{Pump Operation Linits}

The pump bump shall be conducted in accordance with Section 11.2 of this procedure. With TRG approval, this procedure may be used to bump the pump up to 3 times per day. 


\subsection{Abort Criteria}

In the event that an abort condition occurs, pump bumping shall be terminated and shall not be continued without required approval in accordance with LAUR-92-3196 Revised, A SAFETY ASSESSMENT FOR PROPOSED PUMP MIXING OPERATIONS TO MITIGATE EPISODIC GAS RELEASES IN TANK 241-101-SY: HANFORD SITE, RICHLAND, WASHINGTON (referred to herein as the Safety Assessment).

If an alarm is received during pump operation, then exit to the applicable Alarm Response Procedure (ARP), which shall be followed in its entirety.

Abnormal Operating Procedures (AOPs) are provided for those conditions not covered by Alarm Response Procedures. In addition any abort requires followup in accordance with AOP-008, Test Abort Followup Actions.

Initial verification of the operability of all alarm and abort setpoint values is contained in applicable portions of WHC-SD-WM-ATP-046, 101-SY MITIGATION TESTING ACCEPTANCE TEST PROCEDURE, WHC-SD-WM-ATP-058, 101-SY POST PUMP INSTALLATION ACCEPTANCE TEST PROCEDURE and (after the start of Phase B) WHC-SD-WM-ATP-062, PHASE B MITIGATION TESTING SOFTWARE ACCEPTANCE TEST PROCEDURE and WHC-SD-WM-ATP-061, MIT ACCEPTANCE TEST PROCEDURE.

The Test Engineers shall notify the Operations Shift Manager immediately of any abnormal conditions. The Operations Shift Manager shall make any notifications to DOE and management outside the Test Engineers' immediate chain of command.

\subsection{Precautions and Limitations}

3.3.1 In the event of any emergency condition 1isted in Attachment B, the Test Manager and the Operations Shift Manager shall be notified immediately. The Operations Shift Manager shall then implement the applicable portion of HHC-IP-0263-TF, HESTINGHOUSE HANFORO COMPANY BUILDING EMERGENCY PLAN.

3.3.2 If confirmation is not obtained that the pump is running once the pUMp RUNNING circle on the DACS screen is colored green, THEN the pump shall be tripped using the E STOP button. Confirmation that the pump is running requires that both the VSD Keypad speed indication and the independent rpm monitor are in concurrence.

3.3.3 Transition to procedure AOP-006, Contingency Actions shall be made if any of the following conditions occur: tank rollover, hydrogen burn, medical emergency, fire in the DACS Traller, seismic event, severe weather, or conditions listed in Attachment B. 


\section{INSTRUMENTS NO CALIBRATIOH}

The instruments required to be operable prior to and during pump bumping are listed in Attachment A. A system, sub-system, train, component, or device shall be considered OPERABLE or as having OPERABILITY when it is capable of performing its specified function. The operability of the required instruments is verified prior to each itme the pump is operated. The checklist of Attachment $A$ shail be used for this purpose.

Instruments that are connected to the DACS are required to have their DACS alarm and abort values verified according to WHC-SD-WM-ATP-046, 101-SY MITIGATION TESTING ACCEPTANCE TEST PROCEDURE; WHC-SD-WM-ATP-058, 101-SY POST PUMP INSTALLATION ACCEPTANCE TEST PROCEDURE; WHC-SD-WM-ATP-061, MIT ACCEPTANCE TEST PROCEDURE; or WHC-SD-WM-ATP-062, PHASE B MITIGATION TESTING SOFTWARE ACCEPTANCE TEST PROCEDURE, as applicable.

\section{FACILITIES, EQUIPMENT, AND MATERIALS}

The is installed in DST 101-SY, which is located in the 200W area of the Hanford site.

At least once every 24 hours, either a Test Director or a Test Engineer shall verify that the DACS is operational. This shall be done by viewing a DACS history trend display of current data and ensuring that the values are being continually updated. At the time of this verification, an entry shall be made in the Mitigation Test Log to provide record of the DACS operability check.

\section{SAFETY}

6.1 The number of personnel allowed in the DACS trailer between the beginning of pump operation and the completion of step 11.2 .68 shall be 1 imited to the number of SCBAs available in the trafler. All personnel present during these times shall be fully qualified to use SCBAs.

6.2 Al1 requirements set forth in the Safety Assessment for bump operations have been incorporated into this procedure.

6.3 Specific Alarm Response Procedures and Abnormal Operating Procedures are avallable to the Test Engineer and shall be utflized as the need arises.

\section{MAINTEMANCE ND FAILURES}

7.1 The Instruments required to be operable prior to and during pump bumping are listed in Attachment $A$. In the event that the requirements of Attachment $A$ cannot be met, pump bumping shall not proceed without written TRG approval.

7.2 For each instrument in Attachment $A$ that is declared inoperable, perform the following: 
7.2.1 Make an entry in the Mitigation Test Log describing the circumstances.

MOTE: An inoperable instrument that is not disabled may preclude a pump start. Attachment E, Disabling Inoperable Instruments provides the necessary guidance. Permission to disable an instrument does not invalidate the requirements of step 7.1

7.2.2 Obtain the permission of the Test Manager to disable each inoperable instrument.

7.2.3 Make all applicable entries in the Disabled instrument List (maintained in the Required Reading Book).

7.2.3.1 Al1 instruments 1 isted in the O1sabled Instrument List are assumed to remain disabled until the Returned to Service column is signed off.

7.3 Instruments not recorded in the Disabled Instrument List as disabled shall be assumed to be operable.

\section{TEST DATA}

The data collected by the DACS during pump bumping will be recorded and transmitted according to the document WHC-SD-WH-PLN-052, DATA MANAGEMENT PLAN FOR TANK SY-101 HYDROGEN MITIGATION EXPERIMENTS.

Data will be automatically stored by the DACS onto the computer hard drives, which are accessible by DACS station 5 computer. Traceability of data is maintained through the use of instrument tag identification numbers. All data recorded by the DACS are automatically referenced to the appropriate tag numbers. In the event that data are recorded manualiy into the Mitigation Test Log, instrument tag identification numbers shall be used to maintain data traceability.

A blank Comment Sheet is provided at the end of this procedure to document any additional observations, explanations or clarifications that may be useful for data analysis. If used, do not cont inue conments for one bump on the same comment Sheet from another bump; start with a blank copy and ensure all identifying information is included.

\section{PERSONANEL REQUIRENENTS}

This procedure shall be conducted by the quallfied Test Director: and Test Engineers assigned by the Test Manager. No other person shall have Jurisdiction over the conduct of any part of the bump unless spectfically authorized on stated in this procedure. The Test Engineers, Test Directors, Operations Shift Manager, Hest Area Shift Supervisor, and the Test Manager have the authority to stop the pump bump at any time. The responsibilities of these personnel are defined in WHC-SD-WM-MA-014, MITIGATION TEST MANAGEMENT PLAN. 
TYPE B INVESTIGATION REPORT FOR 241-SY-101 PUMP

START AND 241-C-106 PIT CLEANOUT

PUMP BUMP

WHC-SD-WM-TPI-007

FOR

August 2, 1993

TANK 101-SY MITIOATION-BY-MIXING TEST

Rev. 1

At least one Test Director and one Test Engineer shall be present inside the designated CONTROL AREA of the DACS traller at all times during pump operation to ensure that the bump is constantly being monitored and controlled.

A11 Test Directors and Test Engineers shall be aware of the current contents of WHC-SD-WM-PROC-004, A7 arm Response Procedures for Tank 101-SY Mitigation-By-Mixing Test and WHC-SD-WM-PROC-005, Abnormal Operating Procedures for Tank 101-SY Mitigation-By-Mixing Test, as evidenced by their signatures on the Required Reading L1st maintained by the Test Manager.

During periods when the mixer pump is not being operated it will not be necessary for the DACS to be continuously monitored, provided that the 101-SY Mixer Pump and its controls are disabled, locked out, and tagged to prevent inadvertent pump start. It shall be the responsibility of the Test Manager to define the time for which the Test Director and Test Engineer shall remain present in the DACS trailer after pump operation is complete.

\section{MITHESSES}

A Quality Assurance Representative shall witness portions of the bumping effort as necessary to verify that the pump bump is being conducted as written in this procedure and that bump data are being recorded as specified. The quality Assurance Representative shall periodically perform a brief review of the Mitigation Test Log and data sheets during 101-SY Mitigation Testing to verify compliance with this procedure. The Quality Assurance Representative shall signify completion of these reviews with a log entry in the Mitigation Test Log and signatures in section 11 where required. The log book entry shall be initialed and dated by the Quality Assurance Representative.

Page 5 of 50 


\section{PROCEDURES}

Upon completion of each step, the initials of the individual completing the step and the current date shall be placed in the box under each step using black, ballpoint pen. All qual ified Test Directurs and Test Engineers shall provide a sample initfal and signature in the space provided in Attachment $C$ to maintain traceability between initials and personnel.

All procedure steps shall be performed in the order spectfied unless otherwise noted.

Steps requiring INDEPENDENT VERIFICATION shall be performed in accordance with WHC-SP-0708, WESTINGHOUSE HANFORD COMPANY CONDUCT OF OPERATIONS MANUAL. Independent Verification is provided for in a separate sign-off box under each step requiring independent verification.

\section{DEFINITIONS}

- YERIFY: Perform a comparison with the specified requirements. Does not involve manipulation of equipment or instrumentation. May be done by methods other than direct observation.

- ENSURE: To confirm, substantiate, and assure that an activity or condition has been implemented in conformance with the specified requirements or take action to make it so if the activity or condition is not found to be in conformance. May be done by methods other than direct observation.

\section{$\downarrow 11.1$ Pre-start Conditions}

11.1.1 Ensure that all required reading is complete for the Test Director and Test Engineer on duty including a review of recent Mitigation Test Log entries.

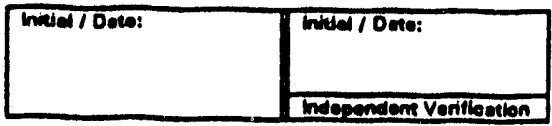

11.1.2 Ensure that [VSD-101-2] TO MIXING PUMP breaker is locked in the OFF position AND is hung with a CAUTION tag.

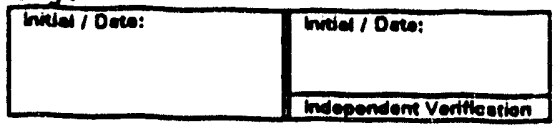

11.1.3 Ensure [VSD-101-1] TO MIXING PUMP ROTATION MOTOR breaker is locked in the Off position AND hung with a CAUTION tag.

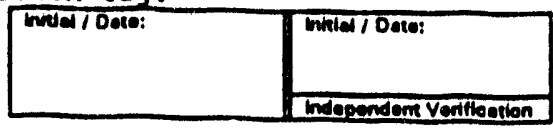

Page 6 of 50 
TYPE B INVESTIGATION REPORT FOR 241-SY-101 PUMP

START AND 241-C-106 PIT CLEANOUT

11.1.4 Reset the GENESIS software to the default settings as follows:

11.1.4.1 At station 5, press $\angle A L T E>$ and enter " $Y$ " to exit the test strategy.

hinde/ Doro:

11.1.1.2 In DOS enter "RUNTIME TEST".

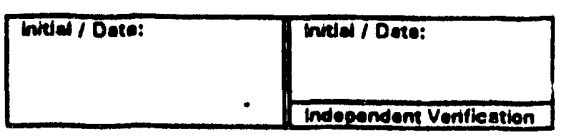

:

11.1.4.3 At station 8, press <ALT E> and enter "Y" to exit the pump strategy.

11.1.4.4 In DOS enter "RUNTIME MOTOR".

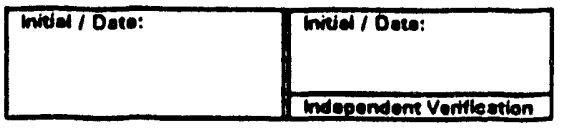

11.1.4.5 Set DACS security level to "WHC" (level 3).

11.1.5 Perform step \& (including all substeps) of Attachment $E$. mivel loote: 
TYPE B INVESTIGATION REPORT FOR 241-SY-101 PUMP START AND 241-C-106 PIT CLEANOUT

PUMP BUMP

FOR

WHC-SD-WM-TPI-007

August 2, 1993

TANK 101-SY MITIGATION-BY-MIXING TEST

Rev. 1

\section{PUMP BUMP}

Steps performed in Section 11.2 may be verified complete by either a Test Director or a Test Engineer.

\subsection{Pump Bump}

NOTE: Steps 11.2.1 through 11.2 .28 may be performed in any order.

* 11.2.1 Complete Attachment A, Minimum Instrumentation Checklist.

Part A Part B

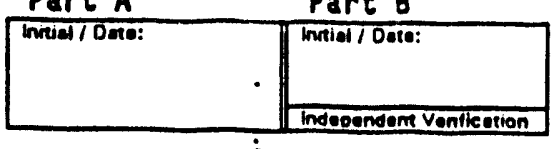

11.2.2 Disable the abort colls of any instruments that were declared inoperable during the performance of step 11.2.1 in accordance with the guldelines in steps 2 through 7 of Attachment $E$, Disabling Inoperable Instruments. (Enter "N/A", if no instruments were disabled.)

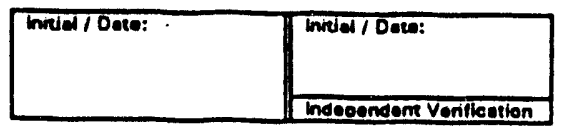

11.2.3 Verify that the Programmable Logic Controller (PLC) abort limits are set correctly in accordance with section 2 of Attachment $D$.

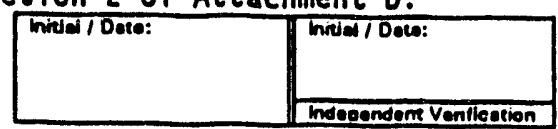

11.2.4 Verify the most recent 7-day average rate of level rise is $<0.15$ in/day. (See section 11.3.)

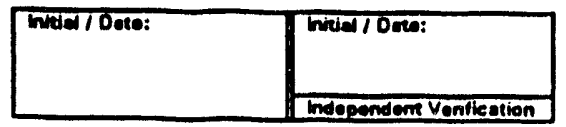

11.2.5 Verify Uninterruptible Power System (UPS) is on-line. hrdeloro:

Page 8 of 50 


\section{TYPE B INVESTIGATION REPORT FOR 241-SY-101 PUMP}

START AND 241-C-106 PIT CLEANOUT

PUMP BUMP

FOR

TANK 101-SY MITIGATION-BY-MIXING TEST

11.2.6 Enter the amount of time following the pump bump that the Test Manager requires the Test Director and the Test Engineer to remain in the DACS Traller:

\begin{tabular}{|c|}
\hline REIAAIN \\
\hline
\end{tabular}

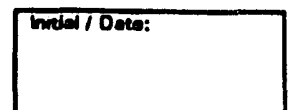

MOTE: The waste level measurements used to satisfy step 11.2 .7 shall be obtained a maximum of 4 hours prior to operating the pump. If any tank level data are obtained from Tank Farm Operations, the measurement should have been made within these four hours.

11.2.7 Verify 101-SY tank level is less than 409.6 inches on all operable level instrumentation. Record actual readings below and time completed:

\begin{tabular}{|r|r|r|}
\hline FIC & RADAR & TAPE \\
\hline inches & inches & inches \\
\hline
\end{tabular}

COMILETE

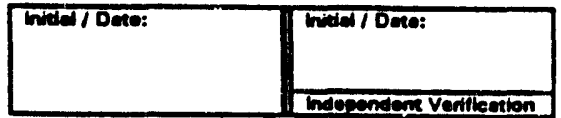

11.2.8 Verify Auxiliary Exhauster (P28) is operable.

Iridet ont:

11.2.9 Verify that pump column pressurization nitrogen bottle pressure $>500$ psig.

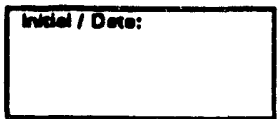

11.2.10 Verify that the pump column centering jack pressures $>100$ psig. 
11.2.11 Calculate the ventilation flow ratio in the box below AND verify that it is 20.66 .

\begin{tabular}{|c|c|}
\hline 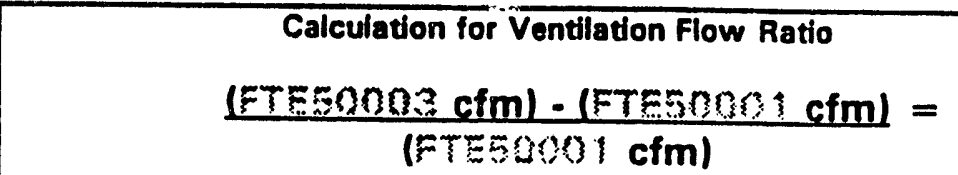 & 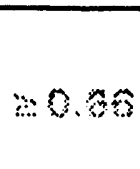 \\
\hline $\begin{array}{l}\text { DACS Tag FTE50003 - SY Tank Farm Exhaust Flow } \\
\text { DACS Tag FTE50001 - Vent Header Flow (101-SY only) } \\
\text { (DACS req FTES0002 }\end{array}$ & \\
\hline
\end{tabular}

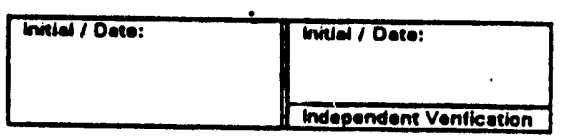

11.2.12 Request West Area Shift Supervisor (373-2920, Radio Station 24) to perform the following:

11.2.12.1 Inform Day Shift (Radio Station 12) of restricted SY Farm access AND install "NO ENTRY" signs at tank farm change station entrances.

Initel Dero:

11.2.12.2 Verify that ventilation flow requirements specified by $P 1$ ant Operating Procedure TO-060-230, OPERATE VESSEL VENT FOR 241-SY TANK FARM are satisfactory for the current shift. Record the verification and name of the shift supervisor in the Mitigation Test Log.

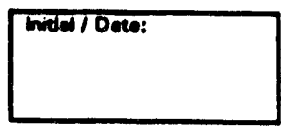

NOTE: The following verifications through step 11.2 .19 may be accomplished by checking for absence of the associated alarms.

11.2.13 Verify tank waste temperature $<135^{\circ} \mathrm{F}$.

Iniden / Dato:

Page 10 of 50 
TYPE B INVESTIGATION REPORT FOR 241-SY-101 PUMP

START AND 241-C-106 PIT CLEANOUT

PUMP BUMP

WHC-SD-WM-TPI-007

FOR

August 2, 1993

TANK 101-SY MITIGATION-BY-MIXING TEST

Rev. 1

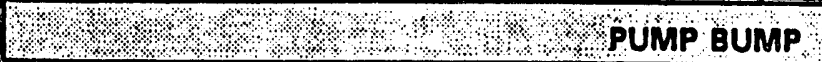

11.2.14 Verify tank dome pressure < -1.0 " w.g.

Grie/ Dote:

11.2.15 Verify 101-SY vent flow $>400 \mathrm{cfm}$.

midel / Dato:

hiden Toto:

11.2.16 Verify 101-SY vent flow $<700 \mathrm{cfm}$.

Inded Doto:

(n)

11.2.17 Verify pump column pressure $>7$ psig.

hitid Tote:

Inidel Dote:

11.2.19 Verify pump column strait
N/A if not avaliable).

( $\pm 194 \mu$ in./in.;

Inidel on:

11.2.20 Verify compliance with Section 6.1.

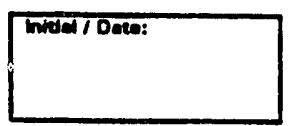

Page 11 of 50 
11.2.21 Ensure that each SCBA includes a mask inside a sealed container AND all SCBA tanks indicate full.

11.2.22 Ensure that abort coll on CSMAIN screen is reset AND both E STOP buttons are reset (in the pulled out position, with red lights on).

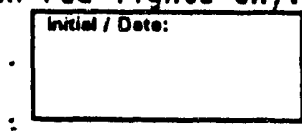

11.2.23 Ensure that the E STOP alarm switch is in the NORMAL position.

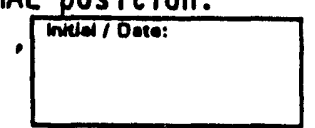

11.2.24 Verify no range fires within 5 miles of $5 Y-101$ tank. (Perform visual inspection of surrounding area and call Hanford Fire Facility at 3732745.)

hade /Den:

11.2.25 Verify no significant thunderstorm activity reported or predicted to occur within 1 hour of pump operation. (Perform visual inspection of surrounding area and call Hanford Meteorological Station at 3732716.)

$$
\begin{aligned}
& \text { Trine } \\
& \text { ConpLETEO }
\end{aligned}
$$

11.2.26 Verify that hydrogen concentration is $<0.2 \%$ by volume (GASSUM screen).

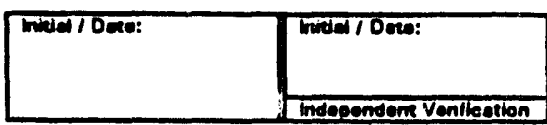


TYPE B INVESTIGATION REPORT FOR 241-SY-101 PUMP

START AND 241-C-106 PIT CLEANOUT

PUMP BUMP

FOR

WHC-SD-WM-TPI-007

August 2, 1993

TANK 101-SY MITIGATION-BY-MIXING TEST

Rev. 1

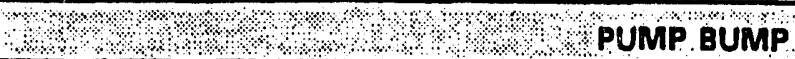

11.2.27 Verify that hydrogen concentration in the vent header is >10 ppm (GASSUM screen, GCI3 H2 PPM Riser 7A).

\begin{tabular}{|c|c|}
\hline Initid / Dene: & Inded / Doto: \\
\hline
\end{tabular}

11.2.28 Ver fy no foaming is present (tank video camera, if avallable; enter "N/A" if not available).

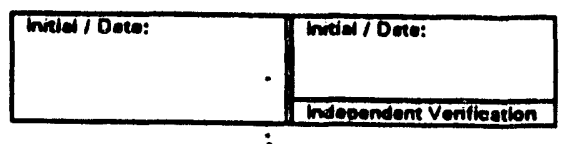

11.2.29 Ensure that steps 11.2.1 through 11.2.28 have been completed.

11.2.30 Ensure that the in-tank video camera is oriented so that the lowest visible portion of the pump column is in view (enter "N/A if not avaflable).

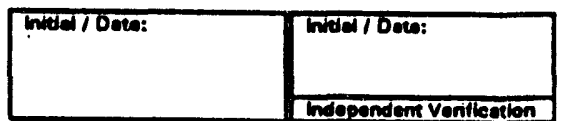

11.2.31 Obtain permission from the Operations Shift Manager (373-2689) to operate the pump AND enter into the Mitigation Test Log the manager's name.

काली 100:

$\star$ 11.2.32 Cal1 the West Area Shift Supervisor (373-2920, Radio Station 24) for the following ftems:

11.2.32.1 Ensure that the "NO ENTRY" signs are posted at the change station entrances to the fenced area of the SY Tank Farm.

Tridiel bots:

Page 13 of 50 
11.2.32.2 Verify all personnel have been evacuated from the fenced area of SY Tank Farm. Independent verification shall require visual observation from the DACS Traller.

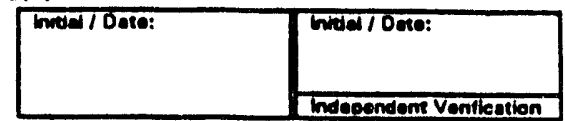

11.2.32.3 Inform the shift supervisor that permission has been granted from the Operations Shift Manager and the pump is about to be operated in DST 101-SY.

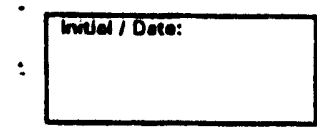

t 11.2.33 Unlock and position the following circuit breakers:

11.2.33.1 Position [VSD-101-2] TO MIXING PUMP to ON.

Wridel Date:

11.2.33.2 POsition [VSD-101-1] TO MIXING PUMP ROTATION MOTOR to ON.

inidel Toen:

11.2.34 Ensure that the two, 2-digit displays on the left side of the PUMP ORIVE keypad read "SP" and "MA" in either order.

mad on:

inderenderi Ventionion

11.2.35 Ensure that the "KPD LOCKED" light is flluminated on both the DIRECTIONAL DRIVE and PUMP DRIVE keypads.

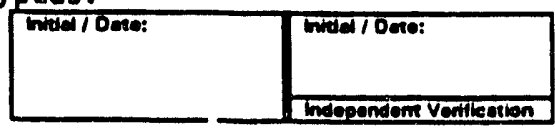


TYPE B INVESTIGATION REPORT FOR 241-SY-101 PUMP START AND 241-C-106 PIT CLEANOUT

11.2.36 Verify at station 8 that independent MOTOR RPM indicator (VRINDRPM) is energized.

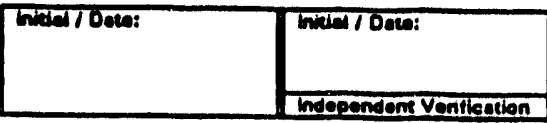

11.2.37 Verify that the DACS is currently recording data by observing that the values on a history trend screen are being periodically updated.

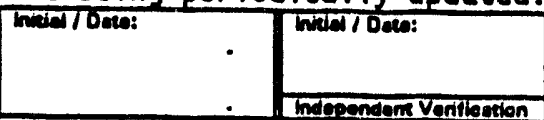

NOTE: Step 11.2 .38 is not required If Phase B Test 19 (section 11.19 of WHC-SDWM-TPI-005, Phase B Test Procedure for Tank 101-SY Mitigation-By-Mixing Test) has been completed.

- 11.2.38 Rotate the Mixer Pump nozzles to the $0^{\circ}$ orientation in accordance with the guidelines of Attachment F, Orienting the Mixer Pump Nozzles (N/A this step if not required):

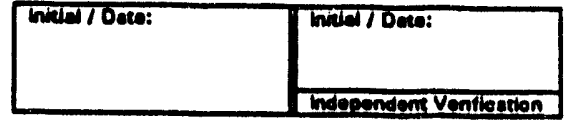

NOTE: - Test Manager may specify a PUMP BUMP SPEED not to exceed $1000 \mathrm{rpm}$ as directed by the Iest Review Group; otherwise, PUMP BUMP SPEED shail be 1 imited to $380 \mathrm{rpm}$.

- Test Manager may specify a SET TIME not to exceed 5 minutes, 0 seconds (05:00), as directed by the TRG.

11.2.39 Enter the required information as directed below:

rpm

PUMP BUAP SPEED minutes: seconds

SET TIME

\begin{tabular}{|l|l|}
\hline hind 1006: & \\
& \\
&
\end{tabular}


TYPE B INVESTIGATION REPORT FOR 241-SY-101 PUMP

START AND 241-C-106 PIT CLEANOUT

PUMP BUMP

WHC-SD-WM-TPI-007

FOR

August 2, 1993

TANK 101-SY MITIGATION-BY-MIXING TEST

Rev. 1

.

11.2.40 Select the "Pump Bump" screen from the MAINMENU screen on DACS station 8 (Pump Control Console).

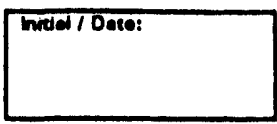

11.2.41 Enter the SET TIME value.

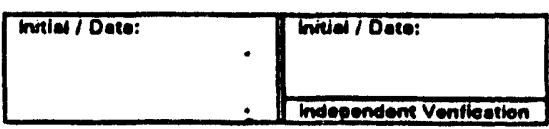

11.2.42 Set the ACCELERATION RATE to $100 \mathrm{rpm} / \mathrm{sec}$.

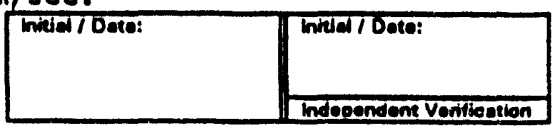

11.2.43 Ensure that the pUmp DECELERATION rate is set to $176 \mathrm{rpm} / \mathrm{sec}$.

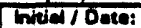

11.2.44 Set the pUmp MAX SPEED to the value for PUMP BUMP SPEED in step 11.2.39.

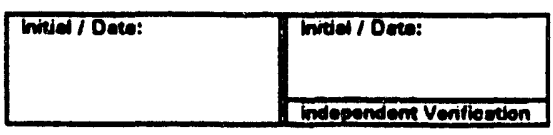

11.2.45 Set the pump SET POINT SPEED to the value for PUMP BUMP SPEED in step 11.2.39.

\begin{tabular}{|l|l|}
\hline hidelow: & \\
& \\
&
\end{tabular}

11.2.46 If any instrumentation determined to be operable in step 11.2.1 is currently in alarm state, obtain the permission of the Test Manager prior to proceeding. Record the Test Manager's permission and time received in the Mitigation Test Log.

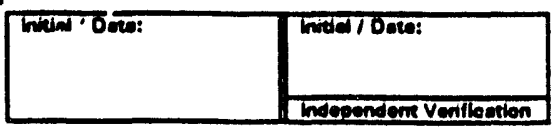

Page 16 of 50 
TYPE B INVESTIGATION REPORT FOR 241-SY-101 PUMP

START AND 241-C-106 PIT CLEANOUT

PUMP BUMP

FOR

WHC-SD-WM-TPI.007

August 2, 1993

TANK 101-SY MITIGATION-BY-MIXING TEST

Rev. 1

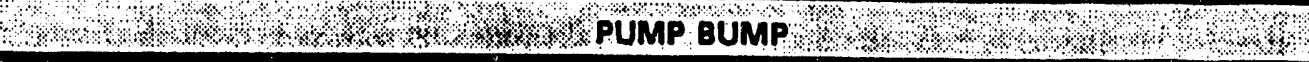

11.2.47 Verify that the time requirements of steps 11.2 .7 and 11.2 .25 are satisfied.

hidelom:

NOTE: Performance of step 11.2 .48 automatically updates alarm and abort limits for pump speed, discharge pressure and motor current to the Pump Bump Requirements and enables the fast scan (1 second) data archive rate.

11.2.48 Select the pump ENABLE box (click with mouse pointer and press <enter>.

11.2.49 Verify, on the PUMP BUMP screen, that the following display fields have updated as indicated in the table below:

\begin{tabular}{|c|c|c|c|}
\hline FIELD MAME & $\begin{array}{l}\text { DISPLAY } \\
\text { VALUE }\end{array}$ & FIELD NAME & $\begin{array}{l}\text { DISPLAY } \\
\text { VALUE }\end{array}$ \\
\hline SPD ALARM & $\max \operatorname{sick0}+10$ & \% CUR ALH: & 205 \\
\hline SPD ABORT & max SPEED + +20 & C CUR ABT & 210 \\
\hline
\end{tabular}

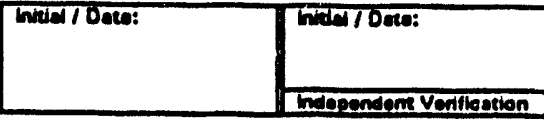

11.2.50 Verify that the display value for the field DISPR ALM corresponds to the curve labled "alarm" on Chart.1, pg. 23 for the input pump speed.

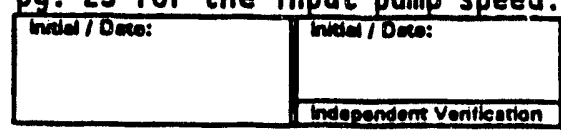

11.2.51 Verify that the display value for the field DISPR ABT corresponds to the curve labled "abort" on Chart 1, pg. 23 for the input pump speed.

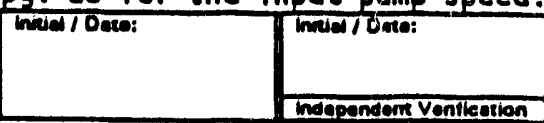

Page 17 of 50 
$\downarrow \quad 11.2 .52$ Verify that only authorized PLC aborts are disabled by performing section 1 of Attachment 0 .

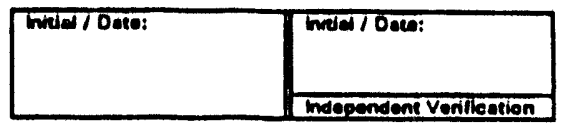

NOTE: Upon completion of step 11.2.53, the "PLC BUMP ENABLED" circle will be colored green for 60 seconds. The pump bump will not proceed If the "BUMP" box is not selected within these 60 seconds (step 11.2.55).

$\downarrow$ 11.2.53 Select the pump ENABLE box (click with mouse jointer and press <enters).

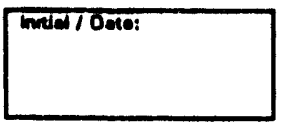

11.2.54 Verify that the "PLC BUMP ENABLED" circle is colored green.

NOTE: Upon activation of the pump in step 11.2 .55 there will be approximately a 5 second delay before the pump "RUNNING" indication is displayed on the DACS.

CAUTION: THE PUMP SHALL NOT BE ALLOWED TO OPERATE FOR MORE THAX THE VALUE OF CAL TIME AFTER INOICATION IS RECEIVED THAT THE PUNP IS RUNHING.

11.2.55 Select the pump BUMP box to initiate the pump bump (click with mouse pointer and press <enter>) ANO record the time.

\begin{tabular}{|l|l|}
\hline START: & \\
\hline TINE: & \\
\hline
\end{tabular}

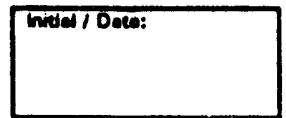

11.2.56 Start the independent stopwatch WHEN the pump's rom increases from zero as displayed on efther the PUMP DRIVE keypad OR the Independent Speed monitor (VRINDRPM).

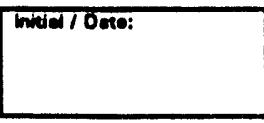

Page 18 of 50 
TYPE B INVESTIGATION REPORT FOR 241-SY-101 PUMP

START AND 241-C-106 PIT CLEANOUT

PUMP BUMP

FOR

WHC-SD.WM-TPI-007

August 2, 1993

TANK 101-SY MITIGATION-BY-MIXING TEST

Rev. 1

+ै

NOTE: The display values for the fields CUR ALM and CUR ABT may not update for short duration pump bumps (less than 15 seconds). This is due to an internal software/hardware time delay.

11.2.57 AFTER the pUmp has run at MAX SPEED for approximately 15 seconds, verify that the current limits have updated, as follows (N/A this step for pump bumps of less than 15 second duration):

11.2.57.1 Verify that the field CUR ALM corresponds to the curve labled

"alarm" on Chart 2, pg. 24 for the input pump speed.

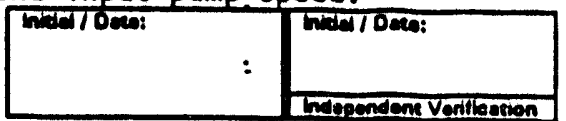

11.2.57.2 Verify that the field CUR ABT corresponds to the curve labled "abort" on Chart 2, pg. 24 for the input pump speed.

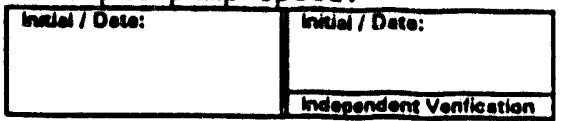

11.2.58 Press the E STOP button WHEN the independent stopwatch reaches the value of SET TIME.

had 100to:

11.2.59 Ensure that the pump has stopped by verifying at station 8 that HMT MIXING PUMP MOTOR POWER, MOTOR RPM, and MOTOR CURRENT indicate less than or equal to zero.

Treat Tota:

11.2.60 Ensure both E STOP buttons are pushed in (red lights are off).

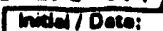

- 11.2.61 Record below and in the Mitigation Test Log the time that the Mixer Pump was stopped.

\begin{tabular}{|l|l|}
\hline STOP \\
TIME \\
\hline
\end{tabular}

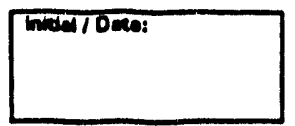

Page 19 of 50 
TYPE B INVESTIGATION REPORT FOR 241-SY-101 PUMP

START AND 241-C-106 PIT CLEANOUT

11.2.62 Position the following circuit breakers:

11.2.62.1 Positton [VSO-101-2] TO MIXING PUMP to OFF AND apply a locking device.

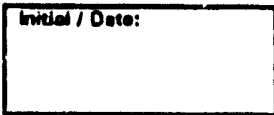

11.2.62.2 POsition [VSD-101-1] TO MIXING PUMP ROTATION MOTOR to OFF AND apply a locking device.

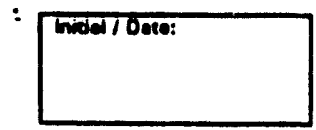

11.2.63 Inform the Operations Shift Manager (373-2689) and West Area Shift Supervisor (373-2920, Radio Station 24) that pump operation has stopped.

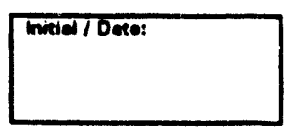

11.2.64 Monitor the tank level, hydrogen concentrattons, and waste surface (using the video camera) to ensure that no abnormal conditions exist for the minimum time specified by the Test Manager in step 11.2.6 following pump operation.

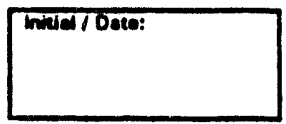

11.2.65 Call the Nest Area Shift Supervisor (373-2920, Radio Station 24) for the following items:

11.2.65.1 Inform the shift supervisor that access to SY farm is now permitted and the "NO ENTRY" signs may be removed.

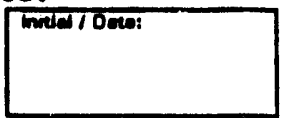

Page 20 of 50 


\section{TYPE B INVESTIGATION REPORT FOR 241-SY-101 PUMP START AND 241-C-106 PIT CLEANOUT}

11.2.65.2 Request the Tank 101-SY post-test waste level and record the results and time completed below. Enter "N/An for any method that is not available:

FIC:

\begin{tabular}{c} 
inches \\
inches \\
\hline TIME \\
CONPLETED \\
\hline
\end{tabular}

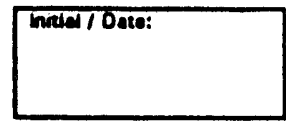

11.2.66 Exit MOOSOFT as follows:

NOTE: Repeat step 11.2.66.1 until the dialog box in step 11.2.66.2 is displayed.

11.2.66.1 Choose "QUIT" from the menu bar.

11.2.66.2 Answer "Y" to the dialog box: "Do you really want to leave Modsoft? $(Y / N)$ ".

11.2.66.3 Answer "Y" to the dialog box: "Offline changes to ... REFERENCE DATA will not be permanently saved to diskl Continue? $(Y / N) "$.

11.2.67 Make an entry inta the Mitigation Test Log describing the pump test activities.

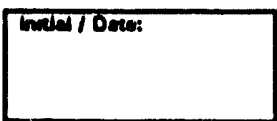

NOTE: The following 3 steps are performed when vacating the DACS Trailer.

11.2.68 Set the GENESIS security level to " 0 " (view only) at DACS stations 5, 6,7 and 8 .

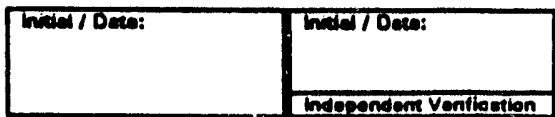


TYPE B INVESTIGATION REPORT FOR 241-SY-101 PUMP

START AND 241-C-106 PIT CLEANOUT

PUMP BUMP

FOR

WHC-SD-WM-TPI-007

TANK 101-SY MITIGATION-BY-MIXING TEST

August 2, 1993

Rev. 1

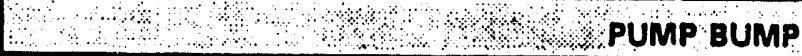

11.2.69 Ensure that the CPU access doors on the computer workstations are closed and locked.

thmiel 10ato:

11.2.70 Ensure that both doors of the DACS trailer are locked.

A quality Assurance review has been conducted as defined in section 10 of this procedure.

:

QA representative signature:

Date.

Page 22 of 50 
OS to EZ abed

I 74845
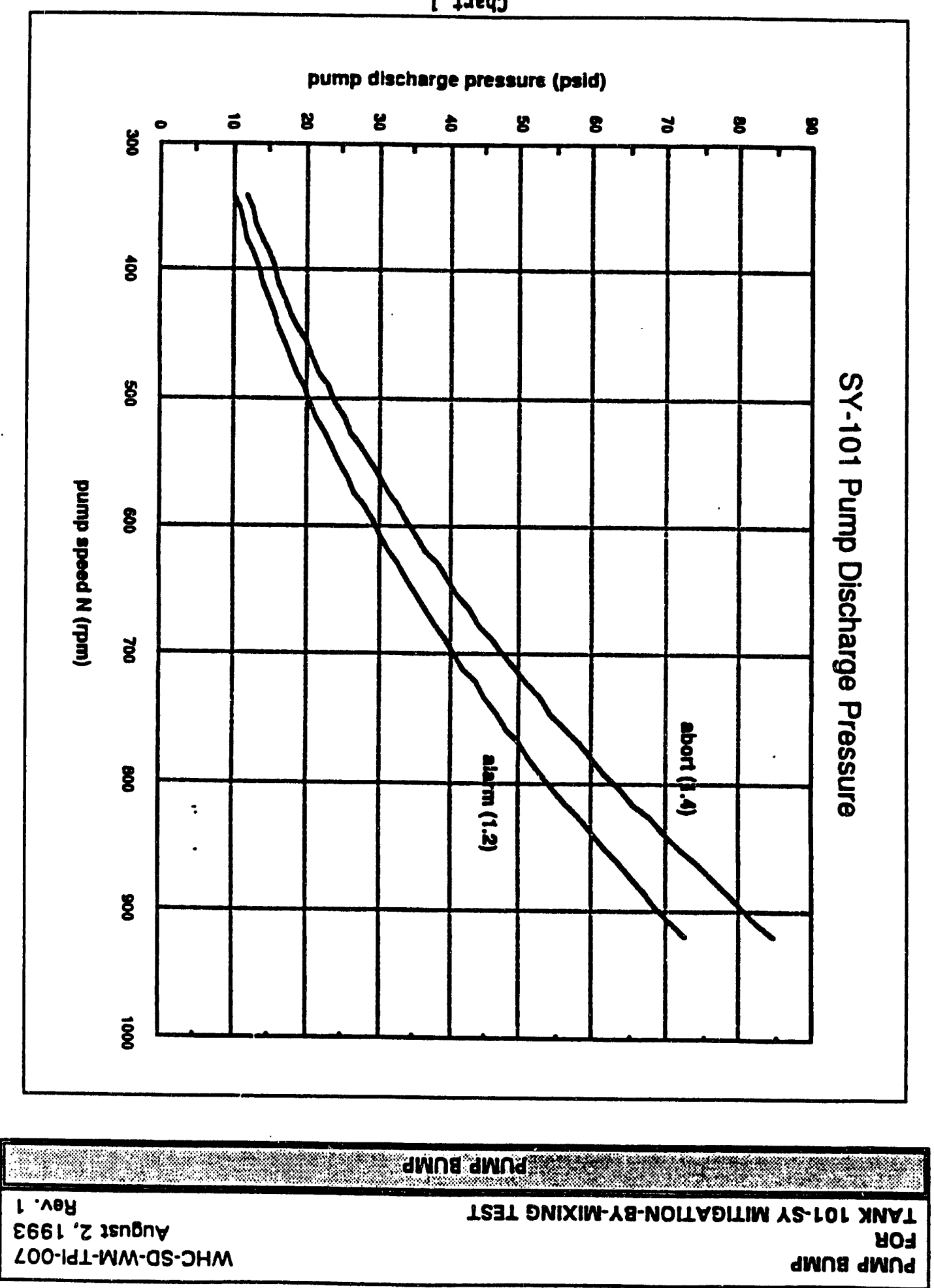
TYPE B INVESTIGATION REPORT FOR 241-SY-101 PUMP START AND 241-C-106 PIT CLEANOUT

TANK 101-SY MITIGATION-BY-MIXING TEST Rev. 1

\%

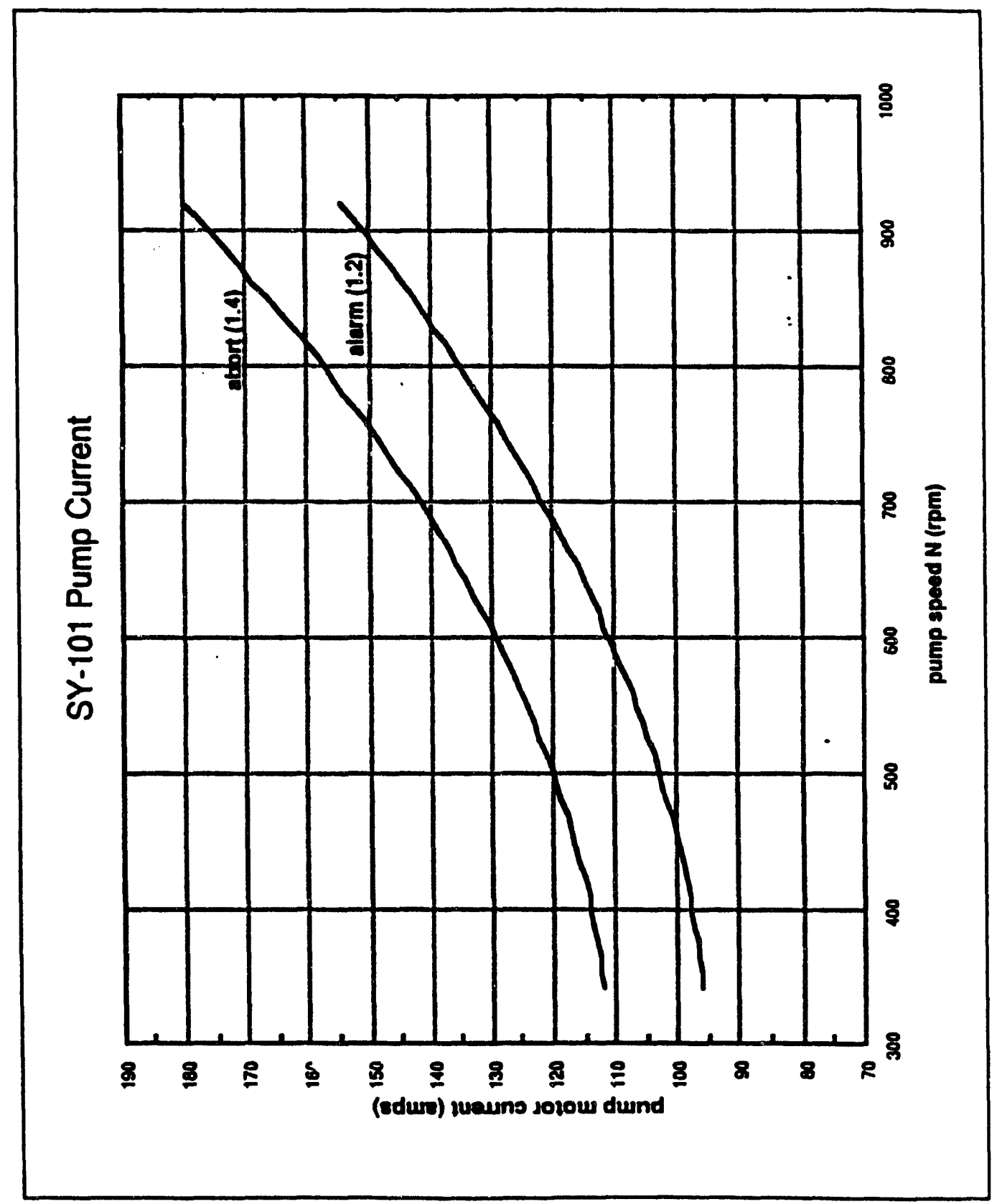

Chart 2

Page 24 of 50 


\subsection{Tank Level Monitoring}

During all phases of testing, the rate of tank waste level rise will be closely monitored. A change in the rate of hydrogen generation, gas retention within the non-convective layer, or the depth of the foam layer near the top of the tank should be detected by an unexpected change in the tank level or a change in the rate of level rise. Safe limits for the tank waste level and the rate of tank waste level rise have been escablished in the Safety Assessment.

The tank waste level shall be recorded on Data Sheet 1, Haste Level Rise Rate in Section 15 once per day, preferably within two pours of 12:00 noon. The tank waste levei shall be determined using the FIC'.

The maximum rate of waste level rise established in the Safety Assessment is $0.15 \mathrm{in} /$ day as a 7-day average. If the average determined in column (6) of Data Sheet 1 exceeds 0.15 , notify WHC Tank Waste Technology Applications (contact N.H. Kirch 373-2380) and request a least-squares analys is of the tank waste level. If a least-squares analys is is performed, record rate of level rise in Comments section of Data Sheet 1 and use the least-squares analysis to satisfy step 11.2 .4 .

\subsection{General Shift Procedures and Requirements}

The mitigation Test Directors and Test Engineers shall conduct the mitigation pump bump in accordance with the applicable sections of the WHC-SP-0708, WESTINGHOUSE HANFORD COMPANY CONDUCT OF OPERATIONS MANUAL.

\section{DISPOSITION OF TEST SUBJECT}

Once the TRG has concluded that all mixer pump testing is completed, the mixer pump will be deactivated and the tank contents allowed to stabilize. The mixer pump will then be removed from DST 101-SY and decontaminated or stored as determined by an as-yet-unwritten procedure.

1 Manual tape may be used if FIC is not avatlable, but must be so noted on Data Sheet 1. 
TYPE B INVESTIGATION REPORT FOR 241-SY-101 PUMP START AND 241-C-106 PIT CLEANOUT

PUMP BUMP

FOR

WHC-SD-WM-TPI-OOT

August 2. 1993

TANK 101-SY MITIGATION-BY-MIXING TEST

Rev. 1

\section{REFERENCES}

13.1 WHC-SD-WM-TP-140, TEST PLAN FOR TANK 101-SY MITIGATION-BY-MIXING TEST, PHASE $A$.

13.2 WHC-SD-WM-TP-153, PHASE B TEST PLAN FOR TANK 101-SY MITIGATION-BY-MIXING TEST.

13.3 LA-UR-92-3196 Revised, A SAFETY ASSESSMENT FOR PROPOSED PUMP MIXING OPERATIONS TO MITIGATE EPISODIC GAS RELEASES IN TANK 241-101-SY: HANFORD SITE, RICHLAND, WASHINGTON (U.S. Department of Energy).

13.4 WHC-SD-WM-ATP-046, 101-SY MITIGATION TESTING ACCEPTANCE TEST PROCEDURE.

13.5 WHC-SD-WM-ATP-058, 101-SY POST PUMP INSTALLATION ACCEPTANCE TEST PROCEDURE.

13.6 WHC-SD-WM-ATP-061, MIT ACCEPTANCE TEST PROCEDURE.

13.7 WHC-SD-WM-ATP-062, PHASE B MITIGATION TESTING SOFTWARE ACCEPTANCE TEST PROCEDURE.

13.8 WHC-SP-0708, WHC CONDUCT OF OPERATIONS MANUAL.

13.9 WHC-SD-WM-MA-014, MITIGATION TEST MANAGEMENT PLAN.

13.10 WHC-SD-WM-PLN-052, DATA MANAGEMENT PLAN FOR TANK SY-101 HYDROGEN MITIGATION EXPERIMENTS.

13.11 WHC-IP-0:363-TF, WHC BUILDING EMERGENCY PLAN.

13.12 H-2-89967, HMT 101-SY TANK MIXING PUMP SYSTEM P \& ID

13.13 UHC-SD-WM-SAD-012, SAFETY ASSESSMENT FOR THE INSTALLATION AND OPERATION OF INLET FILTERS ON TANK 101-SY.

13.14 TO-060-230, OPERATE VESSEL VENT FOR 241-SY TANK FARM.

- 13.15 WHC-SD-WM-TPI-005, PHASE B TEST PROCEDURE FOR TANK 101-SY MITIGATION-BYMIXING TEST.

13.16 WHC-SO-WM-PROC-004, ALARM RESPONSE PROCEDURES FOR TANK 101-SY MITIGATIONBY-MIXING TEST.

13.17 WHC-SD-WM-PROC-005, ABNORMAL OPERATING PROCEDURES FOR TANK 101-SY MITIGATION-BY-MIXING TEST.

$\star 13.18$ WHC-SD-WM-TPI-008, UNPLUGGING 101-SY MIXER PUAP NOZZLES.

13.19 WHC-IP-0842, HASTE TANK PROJECT AOMINISTRATION. 
TYPE B INVESTIGATION REPORT FOR 241-SY-101 PUMP

START AND 241-C-106 PIT CLEANOUT

PUMP BUMP

FOR

WHC-SD-WM-TPI-007

TANK 101-SY MITIGATION-BY-MIXING TEST

August 2, 1993

Rev. 1

\section{PROCEDURE CHANGES}

The Test Director has the authority to make changes to the procedure provided that it is not a change in intent or a change to the administrative controls. Any other changes to the procedure shall require review and approval by TRG. An Engineering thange Notice (ECN) shall be used as the method for changes requiring TRG review and approval.

Test Engineers and Test Directors shall verify by signature in the Required Reading List that they are aware of the current status of all procedures, standing orders and other documents assoctated with Phase A testing of tank 101-SY. The Required Reading List shall be maintained by the Test Manager and located in the DACS Trailer. 
WASTE LEVEL RISE RATE

\begin{tabular}{|c|c|c|c|c|c|c|c|}
\hline $\begin{array}{c}\text { (1) } \\
\text { DATE } \\
\text { (movdo/w) }\end{array}$ & $\begin{array}{c}\text { (2) } \\
\text { TIME } \\
\text { (hh:mm) }\end{array}$ & $\begin{array}{l}\text { (3) } \\
\text { CURRENT } \\
\text { LEVEL } \\
\text { (Inches) }\end{array}$ & $\begin{array}{l}\text { (4) } \\
\text { LEVEL , } \\
\text { DAYS AGO } \\
\text { (Inches) }\end{array}$ & $\begin{array}{c}(5) \\
\text { LEVEL } \\
\text { CHANGE } \\
\text { (3) }-(4)\end{array}$ & $\begin{array}{l}(6) \\
\text { RISE } \\
\text { RATE } \\
(5)+7\end{array}$ & $\begin{array}{c}\text { (7) } \\
\text { INITIALS }\end{array}$ & 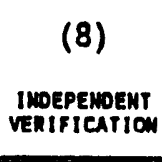 \\
\hline & & & & & & & \\
\hline & & & & & & . & \\
\hline & & & & & & : & \\
\hline & & & & & & & \\
\hline & & & & & & & \\
\hline 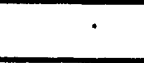 & & & & & & & \\
\hline & & & & & & & \\
\hline & & & & & & & \\
\hline & & & & & & & \\
\hline & & & & & & & \\
\hline & & & & & & & \\
\hline & & & & & & & \\
\hline & & & & & & & \\
\hline & & & & & & & \\
\hline & & & & & & & \\
\hline
\end{tabular}

Comments:

\section{NOTES:}

(2) Level reading should be taken within 2 hours of noon.

(4) Level 7 Days Ago may be obtained from this data sheet or from Tank Farm Operations.

Page 28 of 50 
TANK 101-SY MITIGATION-BY-MIXING TEST Rev. 1

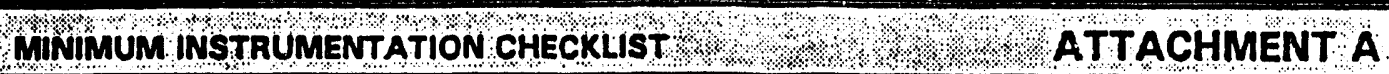

The instrumentation 11 sted in ATTACHMENT A, Minimum Instrumentation Checklists shall be operable prior to and during pump operation.

Perform Part $A$ and Part $B$ independently.

Upon completion of the Checklist the Test Director shall review both parts and ensure they concur with each other. This review shall be documented by the Test Director's signature on the line provided at the end of the Checklist.

A "Comments" section is provided at the end of the Checklist; initial any entries made in this section.

This checklist may be reproduced, as required. 
PART A

Pump Bumping Instrumentation

\begin{tabular}{|c|c|c|}
\hline PART A & Pump Bumping Instrumentation & $\begin{array}{l}\text { Plrst } \\
\text { Verification }\end{array}$ \\
\hline PARAMETER & REQUIREMENTS & OPERABLE \\
\hline $\begin{array}{l}\text { 101-SY Vent } \\
\text { Flow Rate }\end{array}$ & $\begin{array}{l}\text { One flowmeter connected to DACS: } \\
\text { FTE50001 OR } \\
\text { FTE50002 }\end{array}$ & \\
\hline Pump Moisture & $\begin{array}{l}\text { One detector connected to DACS: } \\
\text { MIP00001 }\end{array}$ & \\
\hline $\begin{array}{l}\text { Hydrogen } \\
\text { Concentration }\end{array}$ & $\begin{array}{l}\text { One hydrogen monitor from each of the following } \\
2 \text { Groups shall be operable: } \\
\text { Group 1: } \\
\text { GC3-H2 - } 0-100 \text { PPM VENT HOR } \\
\text { GC2-H2 - 0-100,000 PPM VENT HDR } \\
\text { NIR17BO1 - 0-1\% RISER 17B GMS1 } \\
\text { Group 2: } \\
\text { NIRO5AO1 - 0-10\% RISER 12A SHMS3 } \\
\text { NITJSYO6 - 0-10\% RISER 16A SHMS1 } \\
\text { NITKSYO6 - 0-10\% VENT HDR SHMS2 }\end{array}$ & \\
\hline $\begin{array}{l}\text { Pump Motor } \\
\text { Speed (rpm) }\end{array}$ & One readout on DACS (VR232050) & \\
\hline $\begin{array}{l}\text { Pump Motor } \\
\text { Current }\end{array}$ & $\begin{array}{l}\text { One measurement connected to DACS: } \\
\text { VR232040 }\end{array}$ & \\
\hline $\begin{array}{l}\text { Pump Column } \\
\text { Gas Pressure }\end{array}$ & $\begin{array}{l}\text { One pressure measurement connected to DACS: } \\
\text { ZIMPEI42 }\end{array}$ & \\
\hline $\begin{array}{l}\text { Pump Column } \\
\text { Orientation }\end{array}$ & $\begin{array}{l}\text { Sensor connected to DACS (ZIMPEIII) OR } \\
\text { visual observation required }\end{array}$ & \\
\hline $\begin{array}{l}\text { Nozzle } \\
\text { Discharge } \\
\text { Flow } \\
\text { Indication }\end{array}$ & $\begin{array}{l}\text { The lower waste temperature or fiow element on } \\
\text { each downcomer shall be operable: } \\
\text { TIPNO101 OR FIPNO101 } \\
\text { AND TIPNO202 } \text { OR FIPNO202 } \\
\end{array}$ & \\
\hline Radiation & ARM connected to DACS (for speeds $\geq 530 \mathrm{rpm}$ ) & \\
\hline Waste Level & $\begin{array}{l}\text { FIC Gauge shall be operable and connected to } \\
\text { DACS } \\
\text { ND } \\
\text { One of the following } 2 \text { level indications shall } \\
\text { be operable: } \\
\text { Radar Gauge (LIRI3AO1) } \\
\text { Manual Tape Reading }\end{array}$ & \\
\hline
\end{tabular}




\section{TYPE B INVESTIGATION REPORT FOR 241-SY-101 PUMP \\ START AND 241-C-106 PIT CLEANOUT}

PUMP BUMP

WHC-SD-WM-TPI-007

FOR

August 2, 1993

TANK 101-SY MITIGATION-BY-MIXING TEST

Rev. 1

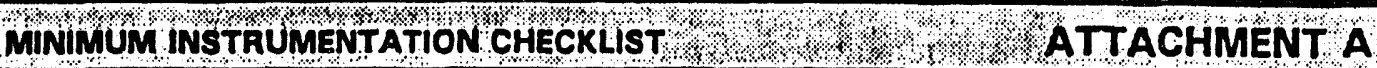

\begin{tabular}{|c|c|c|}
\hline PART A & Pump Bumping Instrumentation & $\begin{array}{l}\text { IIrst } \\
\text { Verifleation }\end{array}$ \\
\hline PARANETER & REQUIREMENTS & OPERABLE \\
\hline $\begin{array}{l}\text { SY Tank Farm } \\
\text { Exhaust Stack } \\
\text { Flow Rate }\end{array}$ & $\begin{array}{l}\text { One measurement connected to DACS or determined } \\
\text { manually: DACS reading } \\
\text { Manual Reading (Reference 13.14) }\end{array}$ & \\
\hline $\begin{array}{l}\text { ETapsed Time } \\
\text { of Pump } \\
\text { Operation }\end{array}$ & $\begin{array}{l}\text { Measured by DACS } \\
\text { NDD } \\
\text { measured by independent stopwatch }\end{array}$ & \\
\hline $\begin{array}{l}\text { Tank Dome } \\
\text { Pressure }\end{array}$ & $\begin{array}{l}\text { One sensor connected to DACS: } \\
\text { PIRI7B04 OR } \\
\text { PIRIIBOI }\end{array}$ & \\
\hline
\end{tabular}

DATE: 
TYPE B INVESTIGATION REPORT FOR 241-SY-101 PUMP START AND 241-C-106 PIT CLEANOUT

PUMP BUMP

FOR

TANK 101-SY MITIGATION-BY-MIXING TEST

MINIMUM INSTRUMENTATION CHECKLIST
WHC-SD-WM-TPI-007

August 2, 1993

Rev. 1

PART A Pump Bumping Instrumentation

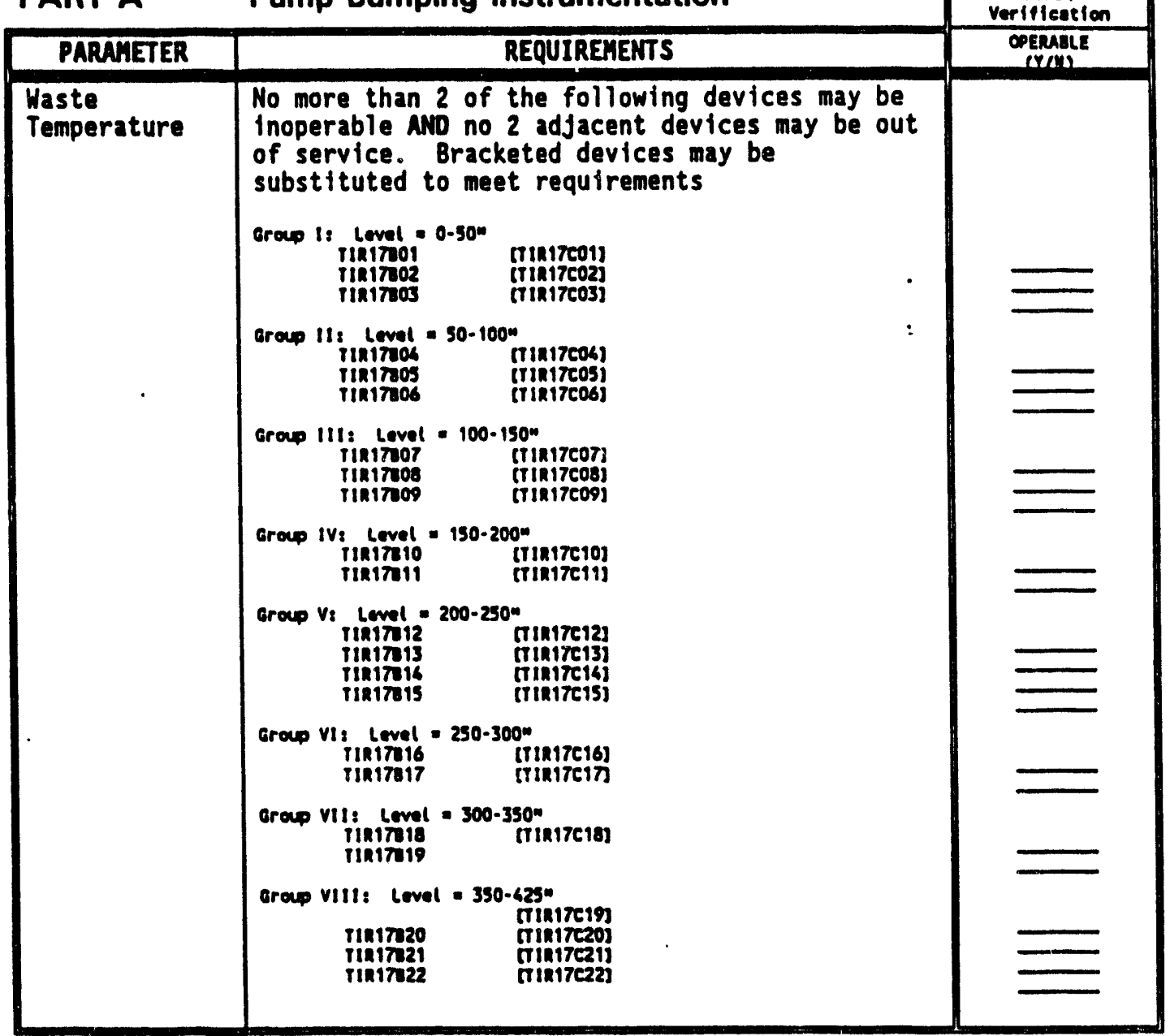


TYPE B INVESTIGATION REPORT FOR 241-SY-101 PUMP

START AND 241-C-106 PIT CLEANOUT

PUMP BUMP

FOR

TANK 101-SY MITIGATION-BY-MIXING TEST

WHC-SD-WM-TPI-007

August 2, 1993

Rev. 1

MINIMUM INSTRUMENTATION CHECKLIST

ATTÁCHMENT A

PART B Pump Bumping Instrumentation

\begin{tabular}{|c|c|c|}
\hline PART B & Pump Bumping Instrumentation & $\begin{array}{l}\text { Independent } \\
\text { verifleat or }\end{array}$ \\
\hline PARAMETER & REQUIREMENTS & $\begin{array}{l}\text { OPERABLE } \\
\text { (YYUL) }\end{array}$ \\
\hline $\begin{array}{l}\text { 101-SY Vent } \\
\text { Flow Rate }\end{array}$ & $\begin{array}{l}\text { One flowmeter connected to DACS: } \\
\text { FTE50001 OR } \\
\text { FTE50002 }\end{array}$ & \\
\hline Pump Moisture & $\begin{array}{l}\text { One detector connected to DACS: } \\
\text { MIP00001 }\end{array}$ & \\
\hline $\begin{array}{l}\text { Hydrogen } \\
\text { Concentration }\end{array}$ & $\begin{array}{l}\text { One hydrogen monitor from each of the following } \\
2 \text { Groups shall be operable: } \\
\text { Group 1: } \\
\text { GC3-H2 - 0-100 PPM VENT HDR } \\
\text { GC2-H2 - 0-100,000 PPM VENT HOR } \\
\text { NIR17B01 - 0-1\% RISER 17B GMS1 } \\
\text { Group 2: } \\
\text { NIRO5AO1 - 0-10\% RISER 12A SHMS3 } \\
\text { NITJSYO6 - 0-10\% RISER 16A SHMS1 } \\
\text { NITKSYO6 - 0-10\% VENT HDR SHMS2 }\end{array}$ & \\
\hline $\begin{array}{l}\text { Pump Motor } \\
\text { Speed (rpm) }\end{array}$ & One readout on DACS (VR232050) & \\
\hline $\begin{array}{l}\text { Pump Motor } \\
\text { Current }\end{array}$ & $\begin{array}{l}\text { One measurement connected to DACS: } \\
\text { VR232040 }\end{array}$ & \\
\hline $\begin{array}{l}\text { Pump Column } \\
\text { Gas Pressure }\end{array}$ & $\begin{array}{l}\text { One pressure measurement connected to DACS: } \\
\text { ZIMPE } 142\end{array}$ & \\
\hline $\begin{array}{l}\text { Pump Column } \\
\text { Orientation } \\
\end{array}$ & $\begin{array}{l}\text { Sensor connected to DACS (ZIMPE112) OR } \\
\text { visual observation required }\end{array}$ & \\
\hline $\begin{array}{l}\text { Nozzle } \\
\text { Discharge } \\
\text { Flow } \\
\text { Indication }\end{array}$ & $\begin{array}{l}\text { The lower waste temperature or flow element on } \\
\text { each downcomer shall be operable: } \\
\text { TIPNO101 OR FIPNO101 } \\
\text { AND TIPNO202 } \quad \text { OR FIPNO202 } \\
\end{array}$ & \\
\hline Radiation & ARM connected to DACS (for speeds $2530 \mathrm{rpm}$ ) & \\
\hline Waste Level & $\begin{array}{l}\text { FIC Gauge shall be operable and connected to } \\
\text { DACS } \\
\text { WNo } \\
\text { One of the following } 2 \text { level indications shall } \\
\text { be operable: } \\
\text { Radar Gauge (LIRI3AOl) } \\
\text { Manual Tape Reading }\end{array}$ & i \\
\hline
\end{tabular}

\%

DATE: 
TYPE B INVESTIGATION REPORT FOR 241-SY-101 PUMP

START AND 241-C-106 PIT CLEANOUT

PUMP BUMP

FOR

TANK 101-SY MITIGATION-BY-MIXING TEST

MINIMUM INSTRUMENTATION CHECKLIST.
WHC-SD-WM-TPI-007

August 2, 1993

Rev. 1

ATTACHMENT A

\begin{tabular}{|c|c|c|}
\hline PART B & Pump Bumping Instrumentation & $\begin{array}{l}\text { Indepondent } \\
\text { Verifieation }\end{array}$ \\
\hline PARAMETER & REQUIREMENTS & OPERMLE \\
\hline $\begin{array}{l}\text { SY Tank Farm } \\
\text { Exhaust Stack } \\
\text { Flow Rate }\end{array}$ & $\begin{array}{l}\text { One measurement connected to DACS or determined } \\
\text { manually: OACS reading } \\
\text { Manual Reading (Reference 13.14) }\end{array}$ & \\
\hline $\begin{array}{l}\text { Elapsed Time } \\
\text { of Pump } \\
\text { Operation }\end{array}$ & $\begin{array}{l}\text { Measured by DACS } \\
\text { AND } \\
\text { measured by independent stopwatch }\end{array}$ & \\
\hline $\begin{array}{l}\text { Tank Dome } \\
\text { Pressure }\end{array}$ & $\begin{array}{l}\text { One sensor connected to DACS: } \\
\text { PIR17804 OR } \\
\text { PIRI1B01 }\end{array}$ & \\
\hline
\end{tabular}


TYPE B INVESTIGATION REPORT FOR 241-SY-101 PUMP

START AND 241-C-106 PIT CLEANOUT

PUMP BUMP

WHC-SD-WM-TPI-007

FOR

August 2, 1993

TANK 101-SY MITIGATION-BY-MIXING TEST

Rev. 1

MHNMUM INSTRUMENTATION CHECKLIST

ATTACHMENT A

\begin{tabular}{|c|c|c|}
\hline PART B & Pump Bumping Instrumentation & $\begin{array}{l}\text { Independent } \\
\text { Veriffication }\end{array}$ \\
\hline PARANETER & REQUIREMENTS & OPERALLE \\
\hline $\begin{array}{l}\text { Waste } \\
\text { Temperature }\end{array}$ & 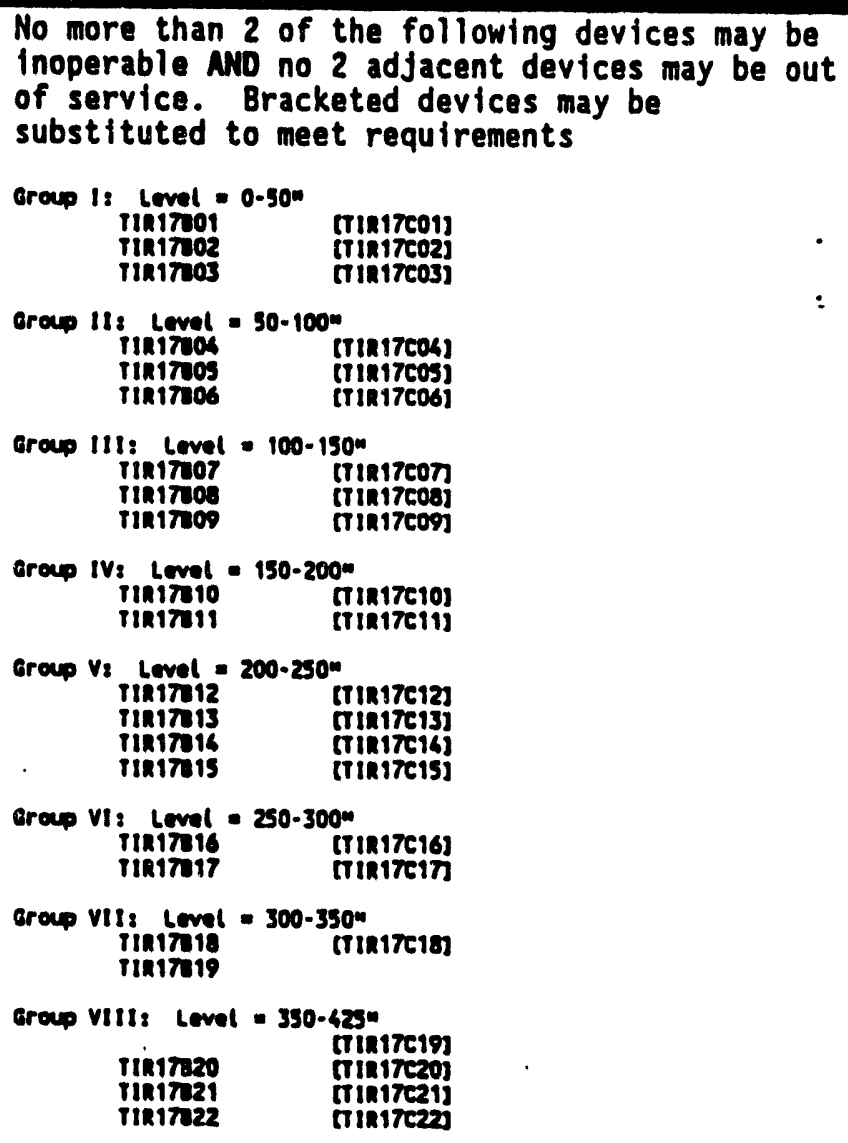 & E \\
\hline
\end{tabular}

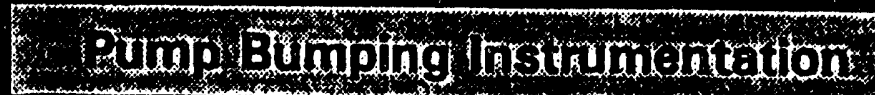

DATE:

Page 35 of 50 
TYPE B INVESTIGATION REPORT FOR 241-SY-101 PUMP

START AND 241-C-106 PIT CLEANOUT

PUMP BUMP

WHC-SD-WM-TPI-007

FOR

August 2, 1993

TANK 101-SY MITIGATION-BY-MIXING TEST

Rev. 1

GINIMUUM INSTRUMMENTATION CHECKLIST

ATTÁCHMENT A

Combents:

This checklist was completed ANO the minimum instruments required have been verifierl operable:

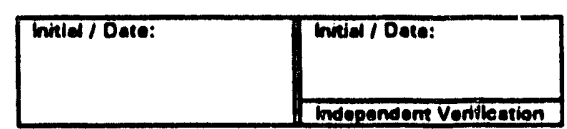

Part $A$ and Part $B$ of this Attachment $A$ are in concurrence with each other.

Test Director signature:

Date:

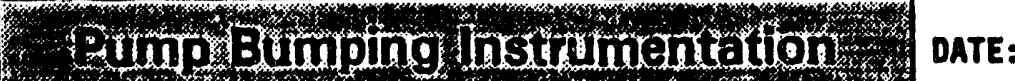

DATE:

Page 36 of 50 
In the event that any of the emergency conditions 1 isted below occur or are suspected, the Operations Shift Manager (373-2689) shall be notified immediately and will then implement the applicable Westinghouse Hanford Company Building Emergency Plan (WHC-IP-0263-TF).

Burp of Waste Tank Accompanied by High Pressure Alarm Suspected Explosion or Fire Confirmed Explosion in SY Tank Farm with Tank Structural Failure Bomb Threat Industrial Accidents

Loss of Electricity

Loss of Water

Loss of Vent1lation

Loss of Steam

Loss of Air

Fire

Major Process Upset

Pressure Hazards

Security Event

Seismic Event

Volcanic Eruption and Ashfall

High Winds or Tornadoes

Flood

Range Fire

Spilis of Hazardous Material

Fires or Explosions Involving Hazardous Materials

Toxic Fumes Hazards

Reactive Chemical and Corrosive Materials Hazards

Thermal Reactions and Hazards

Flammable Material and Liquids Hazards

Asbestos Release

Gaseous Effluent Discharges (Stack Release)

Liquid Effluent Discharge

Significant Contamination Spread or Release

Criticality

Explosive Materials and Munitions Hazards 
TYPE B INVESTIGATION REPORT FOR 241-SY-101 PUMP

START AND 241-C-106 PIT CLEANOUT

PUMP BUMP

WHC-SD-WM-TPI-007

FOR

August 2, 1993

TANK 101-SY MITIGATION-BY-MIXING TEST

Rev. 1

PLCABORT VERIFICATION $\%$ * $\%$ Attachment D

2.4 Verify that the MOD ABORT entry as displayed on screen for each Tag is the same as the corresponding MOO ABORT entry on the hard copy, TABLE DI, Abort Limit Checklist.

2.4.1 Use PART A of TABLE O1 for initial checkoff.

2.4.2 Use PART B of TABLE DI for independent verification checkoff.

2.4.3 If any deviations are noted, notify the Test Manager and do not proceed with this procedure.

2.5 Independent verification shall require performance of step 2.4 only.

Page 40 of 50 


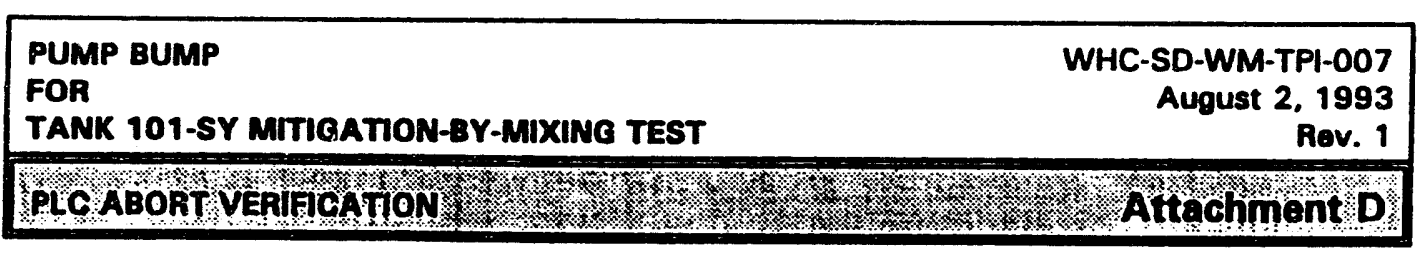

TABLE DI ABORT LIMIT CHECKLIST - PART A

\begin{tabular}{|c|c|c|c|c|c|c|c|c|}
\hline Tag & $\begin{array}{l}\text { Mod } \\
\text { Reg }\end{array}$ & $\begin{array}{l}\text { Mod } \\
\text { A boint }\end{array}$ & $\begin{array}{c}\begin{array}{c}\text { Checkoff } \\
\text { (Initial) }\end{array} \\
\end{array}$ & Description & Unit & $\begin{array}{l}\text { Eng } \\
\text { Low }\end{array}$ & $\begin{array}{l}\text { Eng } \\
\text { High }\end{array}$ & $\begin{array}{l}\text { Eng } \\
\text { Abort }\end{array}$ \\
\hline HH2LIM & 40200 & \% & & HIGH HYDROGEN ABORT LIMIT & $\boldsymbol{x}$ & 0 & 10 & 0.75 \\
\hline UNUSED? & 40201 & 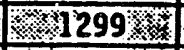 & UNUSED & HIGH WWASTEKLEVEL ABORT LIMIT & 細IN & 397 & (1. 138 & $3 \times 110 \times$ \\
\hline HTEMPLIM & 40203 & 滀1606 & & HIGH TEMP ABORT LIMIT & DEG F & 12.5 & 325 & 135 \\
\hline HPDPLIM & 40204 & VARIABLE & UNUSED & HI PUMP DISCHARGE PRESS ABTLIM & PSI & 0 & 150 & VARIABLE \\
\hline HPMOTLIM & 40206 & $2252 \times x$ & & HIGH MOTOR OIL TEMP ABORT LIM & DEG F & 32 & 383 & 225 \\
\hline LVFLLIM & 40207 & W 1285 \% & & LOW VENT FLOH ABORT LO RANGE & CFM & $\begin{array}{l}0 \\
0\end{array}$ & 1275 & 400 \\
\hline HTDPLIM & 40208 & 1229 稀 & & HIGH TANK DOHE PRESSURE & INWG & -4 & 6 & -1 \\
\hline HPCSLIM & 40209 & 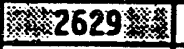 & & HIGH PUMP COLUMN STRAIN & UIN/IN & -684 & 684 & 194 \\
\hline PLCPMCAB & 40210 & \begin{tabular}{|l|} 
VARIABLE \\
\end{tabular} & UNUSED网 & PLC PUMP MOTOR CURRENT ABT LIM & AMPS & 0 & 210 & VARIABLE \\
\hline HMITSLIM & 40211 & (183177\% & & HIGH MIT 17B STRAIN LIMIT & $\mathrm{UIN} / \mathrm{IN}$ & -684 & 684 & 357 \\
\hline H17CSLIM & 40212 & 3117 & & HIGH MIT 17C STRAIN I.IMIT & UIN/IN & -684 & 684 & 357 \\
\hline HPSPDLIM & 40213 & \begin{tabular}{|l|} 
VARIABLEE \\
\end{tabular} & UNUSED & HIGH PUMP SPEED ABORT LIMIT & RPM & $\overline{0}$ & 1200 & VARIABLE. \\
\hline HH2LIML & 40232 & \%30722 & & HIGH H2 ABORT LIMIT 0-50X & $\bar{x}$ & $\overline{0}$ & I & 0.75 \\
\hline HTHPLIM3 & 40234 & \%2341\% & & TEMP ABORT 0-100 & DEG F & 32 & 212 & $\overline{135}$ \\
\hline LVFLLIM2 & 40235 & 688 \% & & LOH VENT FLOH ABORT HI RANGE & CFM & -1000 & 7333 & 400 \\
\hline HTDPLIM2 & 40236 & $655 \times$ & & HIGH DOME PRESS ABORT 2 & INWG & -5 & 20 & -1 \\
\hline HIBCSLIM & 40237 & $6683 \times$ & & HIGH IB COLUMN STRAIN LIMIT & UIN/IN & -684 & 684 & 546 \\
\hline LPCSLIM & 40238 & rix & & LOH PUMP COLUMN STRAIN LIMIT & UIN/IN & -684 & 684 & -194 \\
\hline LAITSLIM & 40239 & $97.9 \times$ & & LOH MIT 178 COLUMN STRAIN LIMIT & $u I N / I N \cdot$ & -684 & 684 & -357 \\
\hline LITCSLI: & 40240 & . $979 \%$ & & LOW MIT 17 C COLUMN STRAIN LIMIT & UIN/IN & -684 & 684 & -357 \\
\hline LIBCSLIM & 40241 & $413 \times 1 \times$ & & LOH IB COLUMN STRAIN LIMIT & UIN/IN & -684 & 684 & -546 \\
\hline LPCGFLIM & 40252 & 147 & & LOH PUMP COL GAS PRESS ABRT LIM & PSI & $\overline{0}$ & 25 & 7 \\
\hline HVFLLIMI & 40253 & 2249 & & HIGH VENT FLOW ABORT LIM I & CFM & $\mathbf{0}$ & 1275 & 700 \\
\hline HVFLLIM2 & 40254 & \%836\% & & HIGH VENT FLOW ABORT LIM 2 & CFM & -1000 & 7333 & 700 \\
\hline
\end{tabular}


TANK 101-SY MITIGATION-BY-MIXINO TEST

Rev. 1

PLCABORTVERIFICATION (7) Attachment D

TABLE DI ABORT LIMIT CHECKLIST - PART B

\begin{tabular}{|c|c|c|c|c|c|c|c|c|}
\hline Tag & $\begin{array}{l}\text { Mod } \\
\text { Reg }\end{array}$ & $\begin{array}{l}\text { Mod } \\
\text { Abont }\end{array}$ & $\begin{array}{l}\text { Checkoff } \\
\text { (Initial) }\end{array}$ & Description & Unit & $\begin{array}{l}\text { Eng } \\
\text { Low }\end{array}$ & $\begin{array}{l}\text { Eng } \\
\text { High }\end{array}$ & $\begin{array}{l}\text { Eng } \\
\text { Abort }\end{array}$ \\
\hline HH2LIM & 40200 & $307 \times$ & & HIGH HYDROGEN ABORT LIMIT & $x$ & 0 & 10 & 0.75 \\
\hline UNUSED & 40201 & $1299 \%$ & ONUSED & HIGH WUASTE KLEVEL, ABORT LIMIT \} $&{\text { \%IN: }} &{397} &{438 \%} &{20110} \\
{\hline \text { HTEMPLIM }} &{40203} &{\text { - } 1606} &{ } &{\text { HIGH TEMP ABORT LIMIT }} &{\text { DEG F }} &{12.5} &{325} &{135} \\
{\hline \text { HPDPLIM }} &{40204} &{\text { VARIABLE }} &{\text { UNUSED躍 }} &{\text { HI PUHP DISCHARGE PRESS ABTLIM }} &{\text { PSI }} &{0} &{150} &{\text { VARIABLE }} \\
{\hline \text { HPMOTLIM }} &{40206} &{2252 \text { 秝 }} &{ } &{\text { HIGH MOTOR OIL TEMP ABORT LIM }} &{\text { DEG F }} &{32} &{383} &{225} \\
{\hline \text { LVFLLIM }} &{40207} &{1285 \%} &{ } &{\text { LOW VENT FLOH ABORT LO RANGE }} &{\text { CFM }} &{0} &{1275} &{400} \\
{\hline \text { HTDPLIM }} &{40208} &{1229 \text { 玟 }} &{ } &{\text { HIGH TANK DOME PRESSURE }} &{\text { INWG }} &{-4} &{6} &{-1} \\
{\hline \text { HPCSLIM }} &{40209} &{\text { 629 }} &{ } &{\text { HIGH PUMP COLUMN STRAIN }} &{\text { UIN/IN }} &{-684} &{684} &{194} \\
{\hline \text { PLCPACABI }} &{40210} &{\text { VARIABLE }} &{\text { UNUSED澄 }} &{\text { PLC PUMP MOTOR CURRENT ABT LIM }} &{\text { AMPS }} &{0} &{210} &{\text { VARIABLE }} \\
{\hline \text { HMITSLIIA }} &{40211} &{3117} &{ } &{\text { HIGH HIT 17B STRAIN LIMIT }} &{\text { UIN/IN }} &{-684} &{684} &{357} \\
{\hline \text { H17CSIIM }} &{40212} &{\text { \%3117\% }} &{ } &{\text { HIGH MIT 17C STRAIN LIMIT }} &{\text { UIN/IN }} &{-684} &{684} &{357} \\
{\hline \text { HPSPDLIM }} &{40213} &{\text { VARIABLE }} &{\text { WUNUSED核 }} &{\text { HIGH PUMP SPEED ABORT LIMIT }} &{\text { RPM }} &{0} &{1200} &{\text { VARIABLE }} \\
{\hline \text { HH2LIM2 }} &{40232} &{3072} &{ } &{\text { HIGH H2 ABORT LIMIT 0-50\% }} &{x} &{0} &{1} &{0.75} \\
{\hline \text { HTHPLIM3 }} &{40234} &{2344 \%} &{ } &{\text { TEMP ABORT } 0-100} &{\text { DEG F }} &{32} &{212} &{135} \\
{\hline \text { LVFLLIM2 }} &{40235} &{\text { 688 }} &{ } &{\text { LOW VENT FLOW ABORT HI RANGE }} &{\text { CFM }} &{-1000} &{7333} &{400} \\
{\hline \text { HTDPLIM2 }} &{40236} &{655} &{ } &{\text { HIGH DOME PRESS ABORT } 2} &{\text { INWG }} &{-5} &{20} &{-1} \\
{\hline \text { HIBCSLIM }} &{40237} &{3683 \text { 㴘: }} &{ } &{\text { HIGH } 1 \mathrm{~B} \text { COLUMN STRAIN LIMIT }} &{\text { UIN/IN }} &{-684} &{684} &{546} \\
{\hline \text { LPCSLIM }} &{40238} &{\text { 1667 }} &{ } &{\text { LOH PUMP COLUMN STRAIN LIMIT }} &{\text { UIN/IN }} &{-684} &{684} &{-194} \\
{\hline \text { LMITSLIM }} &{40239} &{\text { (1. } 97.9 \text {. }} &{ } &{\text { LOW MIT 17B COLUMN STRAIN LIMIT }} &{\text { UIN/IN }} &{-684} &{684} &{-357} \\
{\hline \text { LITCSLIM }} &{40240} &{\text { \% } 979 \text { \% }} &{ } &{\text { LOU MIT 17C COLUMN STRAIN LIMIT }} &{\text { UIN/IN }} &{-684} &{684} &{-546} \\
{\hline \text { LIBCSLIM }} &{40241} &{\text { 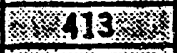 }} &{ } &{\text { LOW } 18 \text { COLUMA STRAIN LIMIT }} &{\text { UIN/IN }} &{-684} &{684} &{-546} \\
{\hline \text { LPCGPLIM }} &{40252} &{1147 \times 2} &{ } &{\text { LOW PUMP COL GAS PRESS ABRT LIM }} &{\text { PSI }} &{0} &{25} &{7} \\
{\hline \text { HVFLLIMI }} &{40253} &{2249} &{ } &{\text { HIGH VENT FLOW ABORT LIM I }} &{\text { CFM }} &{0} &{1275} &{700} \\
{\hline \text { HVFLLIM2 }} &{40254} &{836} &{ } &{\text { HIGH VENT FLOW ABORT LIM } 2} &{\text { CFM }} &{-1000} &{7333} &{700} \\
$\hline
\end{tabular}


TANK 101-SY MITIGATION-BY-MIXING TEST

\section{WARNINGI}

THE IMSTRUCTIONS THAT FOLLOW WILL RESULT IN A REDUCTION OF DACS ABORT CAPABILITY. ABORTS MAY ONLY BE DISABLED HITH THE EXPRESS APPROVAL OF THE TEST MANAGER.

NOTE: - All steps in Attachment E, Disabling Inoperable Instruments shall be performed at DACS Station 1.

- The 〈TAB> key toggles the cursor between the menu bar and the display screen.

- Use TABLE El, Abort Coil Cross Reference to identify the applicable abort coil numbers.

1 Load the current version of the PLC abort files, as follows:

1.1 Change DOS directory by entering "cd C:MMODSOFT" and start MODSOFT program by entering "MODSOFT".

1.2 Choose "FILER" from the menu bar.

1.3 At the "FILE I/O" pull down on the menu bar, choose "Load All" and <enter>.

MOTE: "HFPLC" is the file name of the current version of the PLC abort data.

1.4 Enter "HFPLC" in each of the 6 displayed fields.

1.5 Answer "Y" to the dialog box: "Selecting for LOAD Ready:" to start file loading.

1.6 When files have been loaded, choose "QUIT" from the menu bar.

1.7 At the "ONLINE" pull down on the menu bar, choose "Quick".

1.8 Answer "y" to the dialog box: "The current program will be deleted from the panel. Continue? (Y/N)".

1.9 At the SEGarifT STATUS OISPLAY screen, enter <alt F2> to call up the REFERENCE DATA screen.

2 Enter the abort coil number associated with the inoperable instrument (DACS Tag) in field "Fl" on the REFERENCE DATA screen. 
TYPE B INVESTIGATION REPORT FOR 241-SY-101 PUMP

START AND 241-C-106 PIT CLEANOUT

PUMP BUMP

FOR

WHC-SD-WM-TPI-007

August 2, 1993

TANK 101-SY MITIGATION-BY-MIXING TEST

Rev. 1

DISABLING INOPERABLE INSTRUMENTS \% \%

3 Highlight the "F5" field (using the cursor keys), enter a "O" in the field and press <enter> to disable the selected abort coil.

4 Highlight field "F3" and ensure that the State block displays a zero (abort coll off).

HOTE: Some instruments may have more than one abort coil. This is indicated in TABLE EI by a dashed line separating the coll numbers in the row occupied by the DACS Tag of the instrument.

5 Repeat steps 2 through 4 for each abort cofl associated with an inoperable instrument.

6 Ensure that all appropriate entries are made in the Disabled Instrument List (maintained in the Required Reading book).

7 Verify disabled abort colls by performing steps 1.1 through 1.4 of Attachment D. PLC Abort Verification. 


\begin{tabular}{|c|c|}
\hline $\begin{array}{l}\text { PUMP BUMP } \\
\text { FOR } \\
\text { TANK 101-SY MITIOATION-BY-MIXING TEST }\end{array}$ & $\begin{array}{r}\text { WHC-SD-WM-TPI-007 } \\
\text { August 2, } 1993 \\
\text { Rev. } 1\end{array}$ \\
\hline DISABLING INOPERARLEINS & A \\
\hline
\end{tabular}

TABLE E1 ABORT COIL CROSS REFERENCE

\begin{tabular}{|c|c|c|c|c|}
\hline $\begin{array}{c}\text { OACS } \\
\text { Tag } \\
\end{array}$ & DACS Description & $\begin{array}{c}\text { Modicon } \\
\text { Tag } \\
\end{array}$ & MODICON Coil Description & $\begin{array}{c}\text { Coll } \\
\text { No: }\end{array}$ \\
\hline \multirow{2}{*}{ YTE50001 } & \multirow{2}{*}{ VENT HEADER FLOW LOW RANGE } & FCE50001 & Low Vent 1lation Flow Abort 1 & 308 \\
\hline & & FHE50001 & High Vent Flow Abort 1 & 342 \\
\hline \multirow{2}{*}{ FTE50002 } & \multirow{2}{*}{ VENT HEADER FLOW HIGH RANGE } & FCE5 50002 & Low Ventilation Flow Abort 2 & 309 \\
\hline & & FHE50002 & High Vent Flow Abort 2 & 343 \\
\hline EICABORT & FIC TAMK LEVEL ABORT & FCCABORT & High Waste Tank Level Abort & 261 \\
\hline NIROSAOI & MIX PUMP UTKR MON HI H2 & MCR05A01 & High H2 Abort - Pump & 260 \\
\hline NIR17BOI & RISER 17B WTKR MON/HI H2 & MCR17B01 & High H2 - R1ser 17B Abort & 259 \\
\hline NITJSY06: & R-16A WTKR MON/HI H2 & NCTJSYO6 & High H2 - Riser 16A Abort & 258 \\
\hline WITKSYO6 & EXH HDR UTKR MON/HI H2 & NCTKSYO6 & High H2 - Vent Header Abort & 257 \\
\hline PIRIIBOI & TANK DOME PRESSURE RISER 11B & PCR11B01 & High Tank Dome Pressure Abort 1 & 310 \\
\hline P.CR12AOI & MIXER PUMP PRESSURE & PHR12A01 & High Pump Discharge Pressure Abort & 304 \\
\hline PIRIFBO4 & MIT TANK DOME PRESSURE & PCR17B04 & High Tank Dome Pressure Abort 2 & 311 \\
\hline TIPHO101 & MIX PUMP DIS NOZ 2 TEMP 1 & TCPNO101 & High Temp Abort" Pump 101 & 300 \\
\hline TIPNOIOZ & MIX PUAP DIS NOZ 2 TEMP 2 & TCPNO102 & High Temp Abort Pump 102 & 301 \\
\hline IPNO201 & HIX PUMP DIS MOZ 1 TEMP 2 & TCPNO201 & High Temp Abort Pump 201 & 302 \\
\hline TIPNO202 & MIX PUMP DIS NOZ 1 TEMP 1 & TCPN0202 & High Temp Abort Pump 202 & 303 \\
\hline TIRI2AOI & MIXER PUMP MOTOR OIL TEMP 1 & TCR12A01 & High Pump Motor 011 Temp Abort 1 & 306 \\
\hline
\end{tabular}




\begin{tabular}{|lr|}
\hline PUMP BUMP & WHC-SD-WM-TPI-007 \\
FOR & August 2, 1993 \\
TANK 101-SY MITIGATION-BY-MIXING TEST & Rev. 1 \\
\hline DISABLING IMOPERABLEINSTRUNENTS & Attachment E \\
\hline
\end{tabular}

\begin{tabular}{|c|c|c|c|c|}
\hline $\begin{array}{r}\text { pAcs } \\
\text { Tag } \\
\end{array}$ & DACS Description & $\begin{array}{c}\text { Modicon } \\
\text { Tag }\end{array}$ & MODICON Coll Description & $\begin{array}{l}\text { Cod } \\
\text { No: }\end{array}$ \\
\hline TIR12AOZ & MIX PUMP MOTOR OIL TEMP 2 & TCR12A02 & High Pump Motor 0il Temp Abort 2 & 307 \\
\hline TIRIFBOI & TANK TEMP RISER 178, LVL 4" & TCR17B01 & High Temp Abort 17A01 & 278 \\
\hline TIR17802 & TANK TEMP RISER 178, LVL 16" & TCR17B02 & High Temp Abort $17 \mathrm{AO2}$ & 279 \\
\hline TIRITBO3 & TANK TEMP RISER 178, LVL 28" & TCR17803 & High Temp Abort $17 A 03$ & 280 \\
\hline TIR17.804 & TAMK TEMP RISER 17B, LVL 52" & TCR1?B04 & High Temp Abort 17A04 & 281 \\
\hline T:A17B05 & TANK TEMP RISER 17B, LVL 76" & TCR17B05 & High Temp Abort 17A05 & 282 \\
\hline IR17606 & TANK TEMP RISER 178, LVL 100" & TCR17B06 & High Temp Abort $17 \mathrm{A06}$ & 283. \\
\hline TIRI7BOT & TANK TEMP RISER 178, LVL 112" & TCR17807 & High Temp Abort $17 \mathrm{A07}$ & 284 \\
\hline TIRIVBO8 & TANK TEMP RISER 17B, LVL 124" & TCR17B08 & High Temp Abort 17 A08 & 285 \\
\hline TIRI 7BO9 & TANK TEMP RISER 178, LVL 148" & TCR17B09 & High Temp Abort 17 A09 & 286 \\
\hline TIRIFBIO & TAMK TEMP RISER 178, LVL 172" & TCR17810 & High Temp Abort 17A10 & 287 \\
\hline TIRI7811 & TANK TEMP RISER 17B, LVL 196" & TCR17B11 & High Temp Abort 17A11 & 288. \\
\hline IIR17812 & TANK TEMP RISER 17B, LVL 208" & TCR17B12 & High Temp Abort 17 A12 & 289 \\
\hline TIR17B13 & TANK TEMP RISER 178, LVL 220" & TCR17B13 & High Temp Abort 17A13 & 290 \\
\hline TIR17B14 & TANK TEMP RISER 17B, LVL 232" & TCR17814 & High Temp Abort 17A14 & 291 \\
\hline TIRIFB15 & TANK TEMP RISER 17B, LVL 244" & TCR17B15 & High Temp Abort 17A15 & 292 \\
\hline TIRIJBI6 & TAMK TEMP RISER 178, LVL 268" & TCR17B16 & High Temp Abort 17 A16 & 293 \\
\hline TIRI TB17 & TANK TEMP RISER 178, LVL 292" & TCR17B17 & High Temp Abort 17A17 & 294 \\
\hline
\end{tabular}




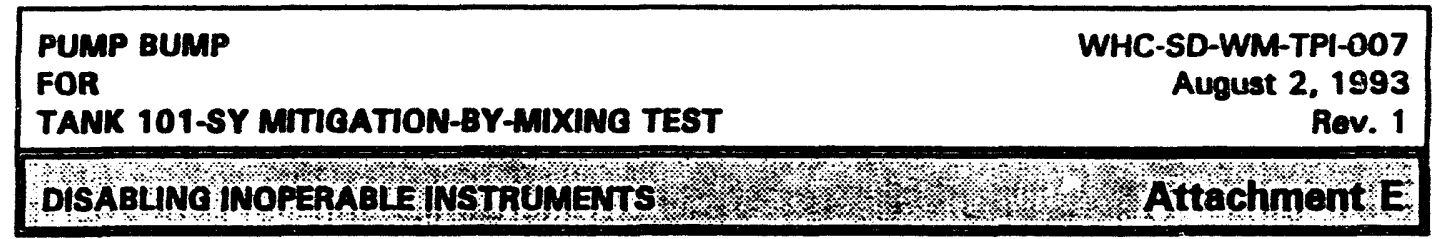

\begin{tabular}{|c|c|c|c|c|}
\hline $\begin{array}{ll}\text { DAcs } \\
\text { Tag }\end{array}$ & DACS Description & $\begin{array}{c}\text { Modicon } \\
\text { Tag }\end{array}$ & MODACON Cefi Description & $\begin{array}{l}\mathrm{Col} \\
\mathrm{No}\end{array}$ \\
\hline TIRIFB & TANK TEMP RISER 178, LVL 326" & TCR17B18 & High Temp Abort 17A18 & $295 \%$ \\
\hline TIR17B19 & TANK TEMP RISER 17B, LVL 340" & TCR17B19 & High Temp Abort $17 A 19$ & 296. \\
\hline TIR17B20 & TANK TEMP RISER 17B, LVL 368" & TCR17B20 & High Temp Abort 17 A20 & 297 \\
\hline TIR17B21 & TANK TEMP RISER 17B, LVL 392" & ICR17B21 & High Temp Abort 17A21 & 298 \\
\hline TIR17B22 & TANK TEMP RISER 178, LVL 402" & TCR17B22 & High Temp Abort $17 A 22$ & $299 \%$ \\
\hline VR232040 & PUMP MOTOR CURRENT & VC232040 & High Pump Motor Current Abort & 325 \\
\hline VR232050 & PUMP SPEED & VC232050 & High Pump Motor Speed Abort & 326 \\
\hline \multirow{2}{*}{ UIR12AOIY } & \multirow{2}{*}{ PUAP SUPPORT COLUMA STRAIN } & WCR12A01 & High Pump Column Strain Abort 1 & 313 \\
\hline & & MLR12A01 & Low 12A-1 Strain Abort & 256 \\
\hline \multirow{2}{*}{ UIRI2A02 } & \multirow{2}{*}{ PUAAP SUPPORT COLUPN STRAIN 12} & HCR12A02 & High Pump Column Strain Abort 2 & 314 \\
\hline & & HLR12A02 & Low 12A-2 Strain Abort & 262 \\
\hline \multirow{2}{*}{ HIRl2A03 } & \multirow{2}{*}{ PUMP SUPPORT COLUMN STRAIN I3 } & HCR12A03 & High Pump Column Strain Abort 3 & 315 \\
\hline & & HLR12A03 & Low 12A-3 Strain Abort & 263 \\
\hline \multirow{2}{*}{ WIRI2AO4 } & \multirow{2}{*}{ PUAP SUPPORT COLUMN STRAIN I4 } & HCR12A04 & High Pump Columin Strain Abort 4 & 316 \\
\hline & & WLR12A04 & Low 12A-4 Strain Abort & 331 \\
\hline
\end{tabular}




\begin{tabular}{|lr|}
\hline PUMP BUMP & WHC-SD-WM-TPI-007 \\
FOR & August 2, 1993 \\
TANK 101-SY MITIGATION-BY-MIXINO TEST & Rov. 1 \\
\hline DISABEING INOPERABEETNSTHUMENTS & Attachment E \\
\hline
\end{tabular}

\begin{tabular}{|c|c|c|c|c|}
\hline $\begin{array}{l}\text { DACS } \\
\text { Tag }\end{array}$ & DACS Description & $\begin{array}{c}\text { Modicon } \\
\text { Tag } \\
\end{array}$ & MODICON Coll Description & $\begin{array}{l}\text { Cod: } \\
\text { No. }\end{array}$ \\
\hline \multirow{2}{*}{ WIR17C01 } & \multirow{2}{*}{ STRAIN GAUGE I7C } & NCR17COI & High MIT Coluan 17C Strain Abort 1 & 323 \\
\hline & & WLR17COI & Low 17C-1 Strain Abort & 339 \\
\hline \multirow{2}{*}{ WIR17c02 } & \multirow{2}{*}{ STRAIN GAUGE $17 \mathrm{C}$} & HCR17C02 & High MIT Colum $17 \mathrm{C}$ Strain Abort 2 & 324 \\
\hline & & WLR17CO2 & Low 17C-2 Strain Abort & 340 \\
\hline \multirow{2}{*}{ WIR17BOI } & \multirow{2}{*}{ STRAIN GAUGE RISER 17B AT LVL } & HCR17801 & High MIT Column Strain Abort 1 & 318 \\
\hline & & HLRI7BOI & Low 17B-1 Strain Abort & 332 \\
\hline \multirow{2}{*}{ UIR17B02 } & \multirow{2}{*}{ STRAIN GAUGE RISER 17B AT LVL } & HCR17B02 & High MIT Column Strain Abort 2 & 319 \\
\hline & & WLR17B02 & Low 17B-2 Strain Abort & 333 \\
\hline \multirow{2}{*}{ WIRIBAOI } & \multirow{2}{*}{ STRAIN GAUGE 1B, LVL 530" } & WCRIBAOI & High VDTT Columen 18 Strain Abort 1 & 320 \\
\hline & & MLR1BA01 & Low 1B-1 Strain Abort & 334. \\
\hline \multirow{2}{*}{ ÜIRIBAOZ } & \multirow{2}{*}{ STRAIN GAUGE RISER IB AT 530" } & WCR1BA02 & High 1B-2 Strain Abort & 337 \\
\hline & & WLR1BA02 & Low 1B-2 Strain Abort & 335 \\
\hline \multirow{2}{*}{ UIRIBA03 } & \multirow{2}{*}{ STRAIN GAUGE 18, LVL 530" } & HCR1BA03 & High VDTT Column 1B Strain Abort 2 & 321 \\
\hline & & HLRIBA03 & Low 1B-3 Straini Abórt & 336 \\
\hline ZIMPEI42 & MIXER PUMP COLUMW GAS PRESSURE & ZLMPE142 & Low Pump Column Gas Pressure Abort & 341 \\
\hline
\end{tabular}


TYPE B INVESTIGATION REPORT FOR 241-SY-101 PUMP

START AND 241-C-106 PIT CLEANOUT

PUMP BUMP

FOR

WHC-SD-WM-TPI-007

August 2, 1993

TANK 101-SY MITIOATION-BY-MIXING TEST

Rev. 1

ORIENTINO THE MIXEA PUMP NOZZLES

Attachment F

NOTE: - Actions described in Attachment F, Orienting the Nixer Pump Nozzles must be performed at the DACS Pump Control Console, station 8.

- These guidelines assume that [VSD-101-1], TO MIXING PUMP ROTATION MOTOR breaker and [VSD-101-2], TO MIXING PUMP breaker are closed/on.

1 Select the "Manual Nozzle Positioning" soft button from the MAINMENU screen.

2 In the "Set Pump Position" portion of the screen, enter the desired nozzle orientation (in degrees) in the field labeled SET POINT POSITION.

3 Ensure ENABLE MOVE is displayed in the field immediately below SET POINT POSITION by using the <space bar> as a toggle.

4 Press the <enter> button and observe the "Nozzle Position (deg)" display.

5 Verify that Meas (measured position) Indicator AND Sotp (set point position) indicator are both lit green AND indicate the desired position. 
TYPE B INVESTIGATION REPORT FOR 241-SY-101 PUMP

START AND 241-C-106 PIT CLEANOUT

PUMP BUMP

FOR

TANK 101-SY MITIGATION-BY-MIXING TEST

\section{Comment Sheet}

Comments for procedure section:

; Test :

DATE:

Inttial each entry

page___ of

Page 50 of 50 
TYPE B INVESTIGATION REPORT FOR 241-SY-101 PUMP

START AND 241-C-106 PIT CLEANOUT

APPENDIX G

241-C-106 DOCUMENTATION

G-1 
This page intentionally left blank. 


\section{TYPE B INVESTIGATION REPORT FOR 241-SY-101 PUMP START AND 241-C-106 PIT CLEANOUT}

(29) Westinghouse

Hanford Company

WAF REDISTRIBUTION $05 / 06 / 93$

P.O. Box 1970 Richland. WA 99352

May 5, 1993

JR STREDWICK

:CW-NEEDHAM

9353885

W. A. Ferree, Area Manager

Kaiser Engineers Hanford

P. 0. Box 888

Richl and, Wa. 99352

CWN/REDISTRIBUTION/5-6-93

C. A. Challender

Const. Document Control

Dear Mr. Ferree:

SUBJECT TANK 106-C PIT CLEAN OUT AND PAINTING

INTRODUCTION This letter is to serve as authorization for Kaiser

Construction to begin procurement and fabrication of the equipment identified in the "SPECIAL EQUIPMENT" section of this letter, for the clean out and painting activities on Tank 106-C Pits. An additional Letter of Instruction will be sent to begin the actual field work.

SCOPE This activity is to include the procurement and fabrication of the

Special Equipment required to support this effort.

SPECIAL EQUIPMENT Kaiser is to purchase an $8 \times 12$ foot four wheel flat bed trailer for equipment and supplied air system transport. This trailer is to be modified like the TMACS trailer you are building for Mr. Ron Jones of Major Maintenance. Provisions also need to be made for attaching fresh air bottle racks to the crane which will ad in this effort.

SCHEDULE Please begin this nmediately. Additional LOI's for starting field work will fol

SAFETY This work is to be performed in accordance with prescribed KEH safety procedures and practices. If any abnormal conditions become apparent to either KEH or WHC, notification will be made to both companies in writing.

COST All costs associated with this activity should be charged to Work Order ER-3022.

PROCUREMENT All materials are to be supplied by,KEH.

JCS WORK PACKAGE 2W-9̈̈-00613.

POSNT OF CONTACT The point of contact for this activity is David Berg,. 3-4961.

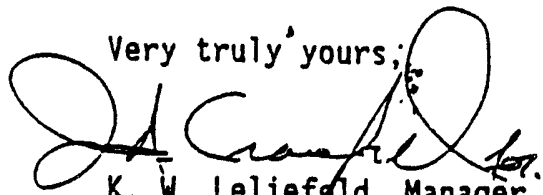

K. W. Leliefeld, Manager

Major Maintenance Upgrades

$\mathrm{db}$

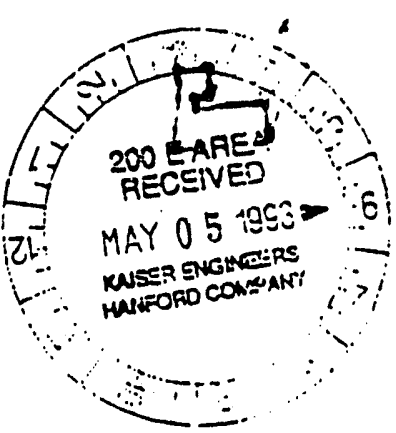

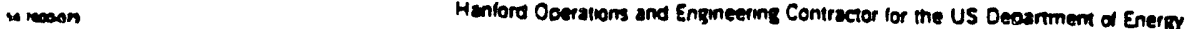




\section{TYPE B INVESTIGATION REPORT FOR 241-SY-101 PUMP START AND 241-C-106 PIT CLEANOUT}

\section{(28) Westinghouse \\ Hanford Company}

P.O. Box 1970 Riehiand. WA 99362

June 4, 1993

9355042

H. A. Ferree, Area Manager

Kaiser Enginears Hanford

P. 0. Box 888

Richland, Wa. 99352

Dear Mr. Ferree:

SUBJECT - H-320, PUMP PIT CLEAN OUT 241-C-106

REFERENCE: Request for Estimate LOI\$ 935911 and Start Fabrication, Procurement LOI\$ 9353885 .

IMTROOUCTION This LOI authorizes KEH to start work on clean-out of pump pits $C-106 A, B$, and $C$.

SCOPE Tapk 241-C-106 pits A (pump pit), B (center heel pit), C (south sluice Pft) are to be cleaned-out, decontaninated, and painted.

The pit covers are to be removed and all extsting equipment and debris removed. Equipment removed at this time is inclusive of all material presently in the pits with the exception of pumps and "Isolation blanks" presently: in risers and pit penetrations. All jumpers, unused blanks, and miscellancous debris is to be removed and placed in approved type A disposal contalners. KEH will transport this waste to WHC Solld Waste facilities yet to be determined. No material is to be placed in contalners until this determination has been made.

Pit wal1s; floors, and covers are to be decontaminated to the greatest extent possible. Decontanination efforts will be considered complete when two consecutive smears (between decon efforts) on each surface show no reduction of contamination level. Decontamination will be performed by either water spray or CO2 pollet impingement.

Pit walls, floors, and covers will be painted to the requirements of Federal Specification (FS) T-P-645 for the primer caat and (FS) TT-E-489 for the finish cost(s). Further definitive instruction will be provided by JCS work request 2E-93-0613-K, KEH will work to the requirements of this work package. No PCI will be necessary. This is a Safety Class 3 Impact Level 35 work effort.

DELIVERAE!Es Any inspections required will be performed by WHC Quality Control. A letter of completion will be required from Construction Forces stating that the above scope of work has been completed.

SCriétule: This work is scheduled to be performed from July 21, 1993 through August 31, 1993. 
SAFETY This work is to be performed in accordance with prescribed KEH safety procedures and practices. If any abnormal condittons become apparent to efther KEH or WHC, immediate notification wlll be made to both companies with follow-up notification in writing. No known asbestos source is located within the work area. Al1 work within 241-C tank farm w111 be performed with personnel on supplied air due to the known vapor hazard in the tank farm. Radiologikal condition as incountered at the last plt entry have been prevtousiy provided.

CoST All costs assoclated with equipment removal and transportation should be charged tp Work Order ER-3986. All costs incurred in cleaning and painting the pits should be charged to Work Order ER-3985.

PROCURENEIT All matertal requtred to complete this work wtll be supplied by KEH.

PERAITs WHC will provide the Radlation Work Permit, KEH will provide any other perpits required (JSA etc.)

JCS WORK PACKAGE KEH is requested to perform the work scope identified in JCS work request 2E-93-0613-K. Adherence to the requirements of this work request is mandatory.

PorkT of tontact Mr. David Berg (3-4961) of WHC's Major Maintenance organization will be Construction Supervistons' primary point of contact. Should he be unavailable for any reason lir. Tim Shaw (2-0305) of my staff is the SST Retrieval Operations/Construction 1 iason.

Very truly yours,

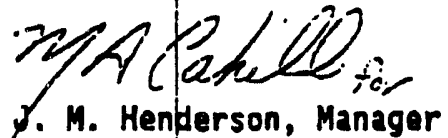

SST Retrieval 
TYPE B INVESTIGATION REPORT FOR 241-SY-101 PUMP START AND 241-C-106 PIT CLEANOUT

\begin{tabular}{|c|c|c|c|c|c|c|c|}
\hline J-9 & \multicolumn{3}{|c|}{ PARTIAL RELEASE SHEET } & \multicolumn{4}{|c|}{$2 E_{1}-9,3_{1}-0_{1} 0_{1} 6_{1} / 3_{1} K$} \\
\hline 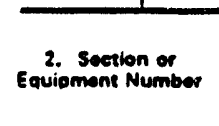 & 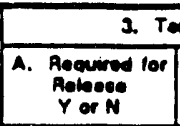 & 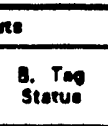 & $\begin{array}{l}\text { 4. Aotoosod } \\
\text { Sibrionere }\end{array}$ & $\begin{array}{l}\text { 5. Ac Comsinete } \\
\text { Sionnioute }\end{array}$ & 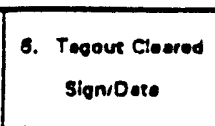 & 7. Rocour comolater & 8. Wortc Comolote \\
\hline $\begin{array}{l}J 43 \\
\text { STO5 }\end{array}$ & $N$ & $N A$ & $\begin{array}{l}0,1 / 16025 \\
7-19-93\end{array}$ & 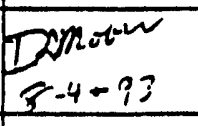 & $N / A$ & $N / A$ & 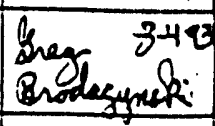 \\
\hline & & & & & & & \\
\hline & & & & $\therefore$ & & . & \\
\hline & & & & & & $:$ & \\
\hline & & & & & & & \\
\hline & & & & & & & \\
\hline & & & & & & & \\
\hline & & & & & & & \\
\hline & & & & & & & \\
\hline & & & & & & & \\
\hline & & & & & & & \\
\hline & & & & & & & \\
\hline & & & & & & & \\
\hline & & & & & & & \\
\hline & & & & & & & \\
\hline . & & & & & & & \\
\hline
\end{tabular}




\section{TYPE B INVESTIGATION REPORT FOR 241-SY-101 PUMP START AND 241-C-106 PIT CLEANOUT}

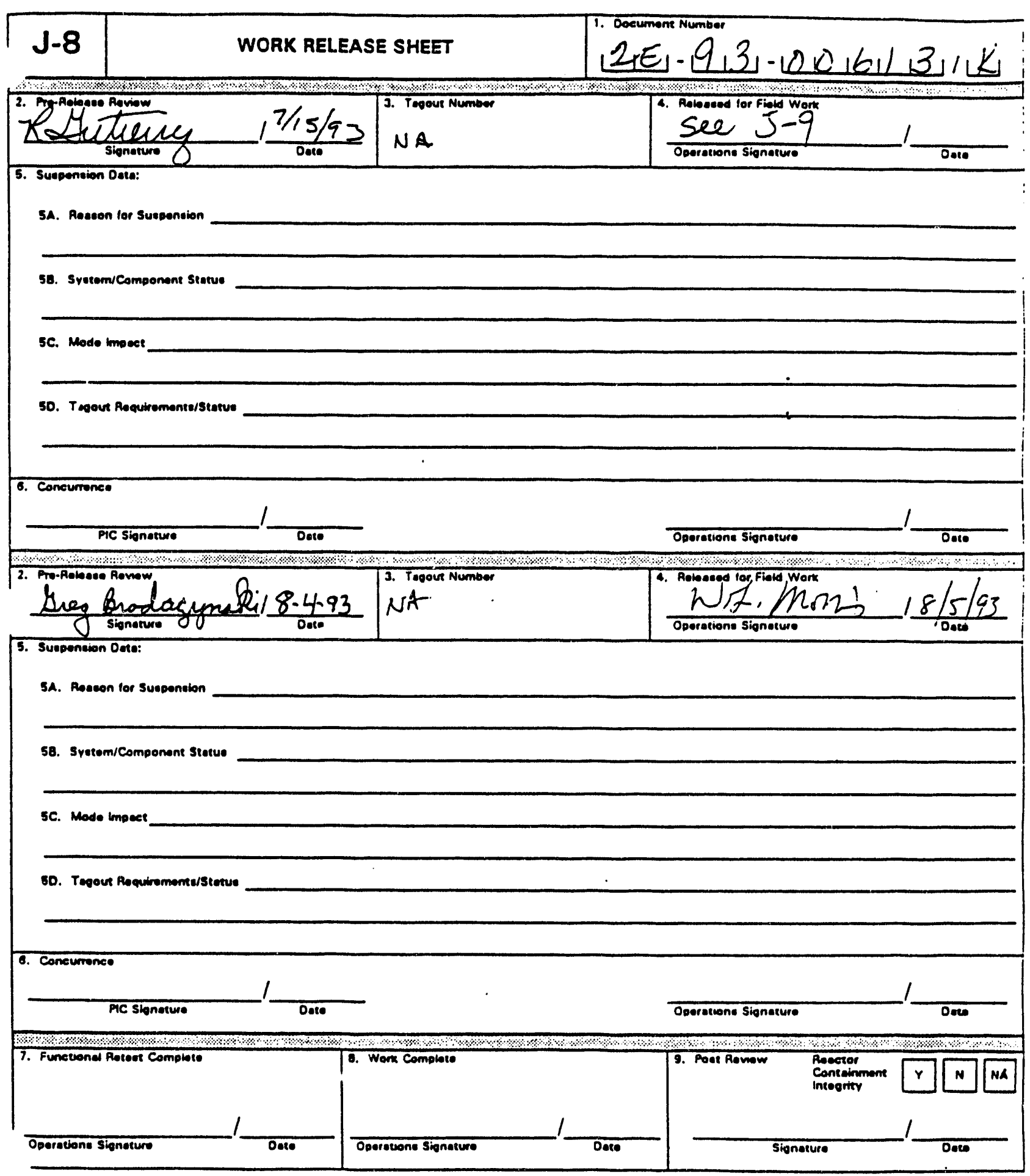




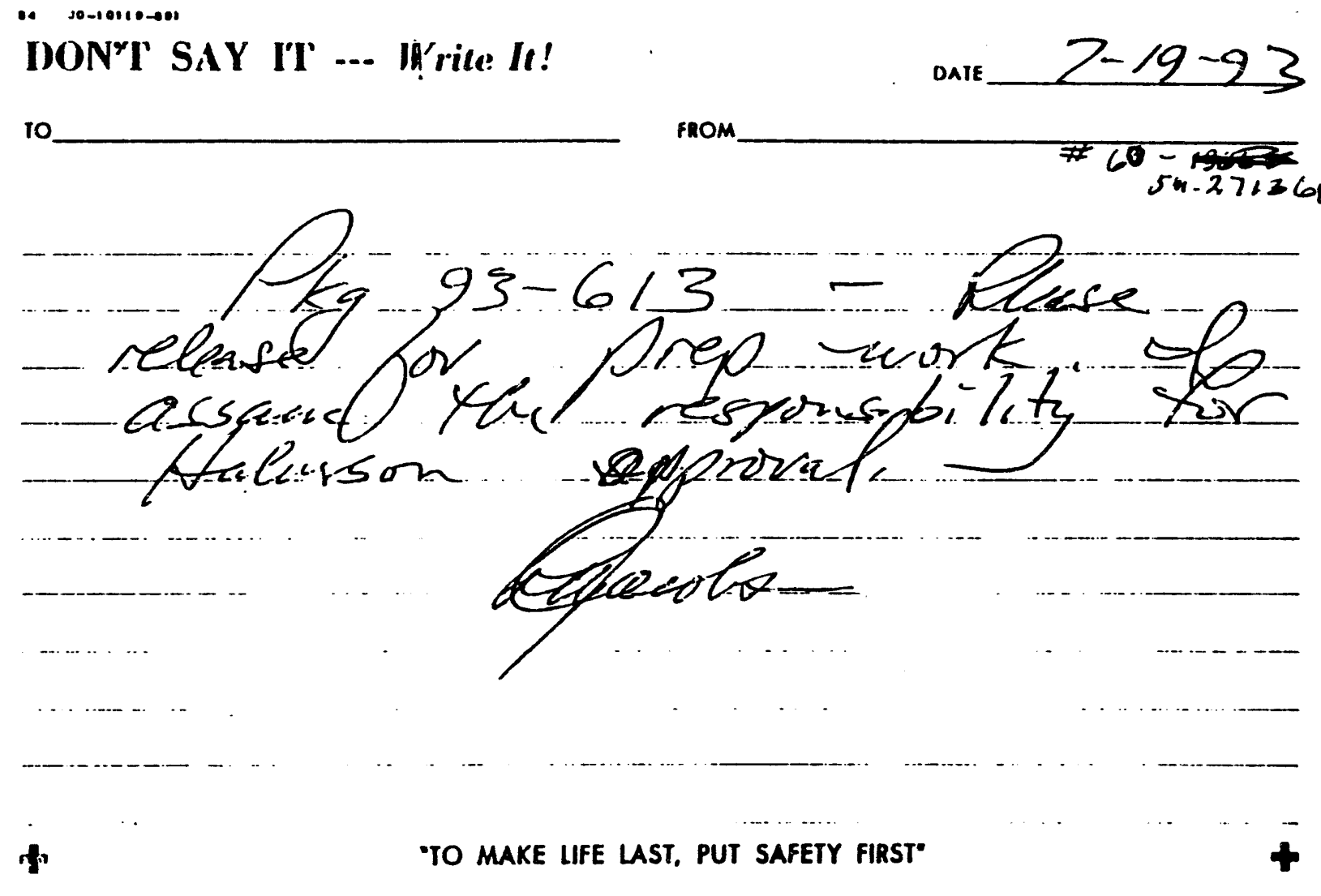




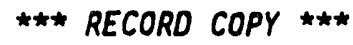

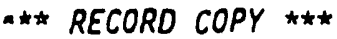

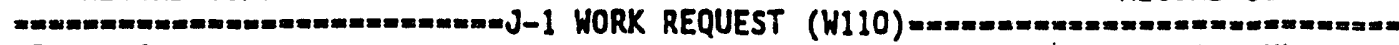

Page: 1

11:29:42 14 JUL 1993

1. Document Number 2E-93-00613/K CONSTRUCTION WORK

2. Work Item Title *106-C PIT CLEANOUT \& PAINTING

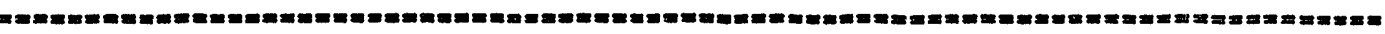

3. System GEN GENERAL

4. Components

Component Number Name

$N / A$

Temporary Number

$N / A$

Name

N/A

5. Location

Facility 2E EAST TANK FARMS

Bldg/Rm 241-C

other TANK 106-C other

6. Associated Components

Component Number

N/A

Name

7. Originator Name BERG,DA

Telephone No. 3-4961

MSIN 50-09

$\begin{array}{cc}\text { Date } & \text { Organization } \\ 04 / 01 / 93 & \\ 7 C 410\end{array}$

8. Charge Code IN1B23

9. Hork Item Description

REMOVE ALL EQUIPMENT FROM THE 106-C PITS, DECON THE SURFACES, AND REPAINT.

10. Operations Review

11. Priority

12. Phase Designator

13. Correct Maint. Assessment $M$

14. Personnel Safety Related N

15. Cognizant Engineer

16. Cognizant Manager

RUFFIN.L

BEIBESHIMER, E

17. Reference Documents

Type
Signature Date

XESTER, Gr

2

2-1 APRIL

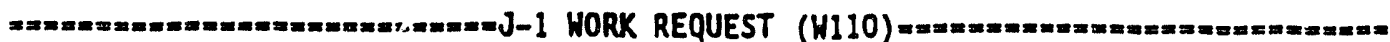




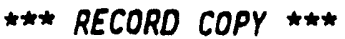

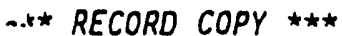

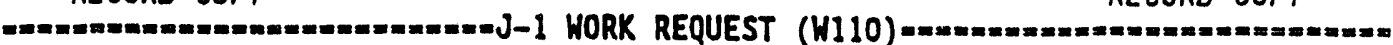
Page: 2

$11: 29: 42 \quad 14$ JUL 1993

1. Document Number 2E-93-00613/K CONSTRUCTION WORK

2. Work Item Title *106-C PIT CLEANOUT \& PAINTING

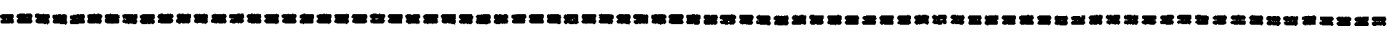

18. Corments

- 


\section{START AND 241-C-106 PIT CLEANOUT}

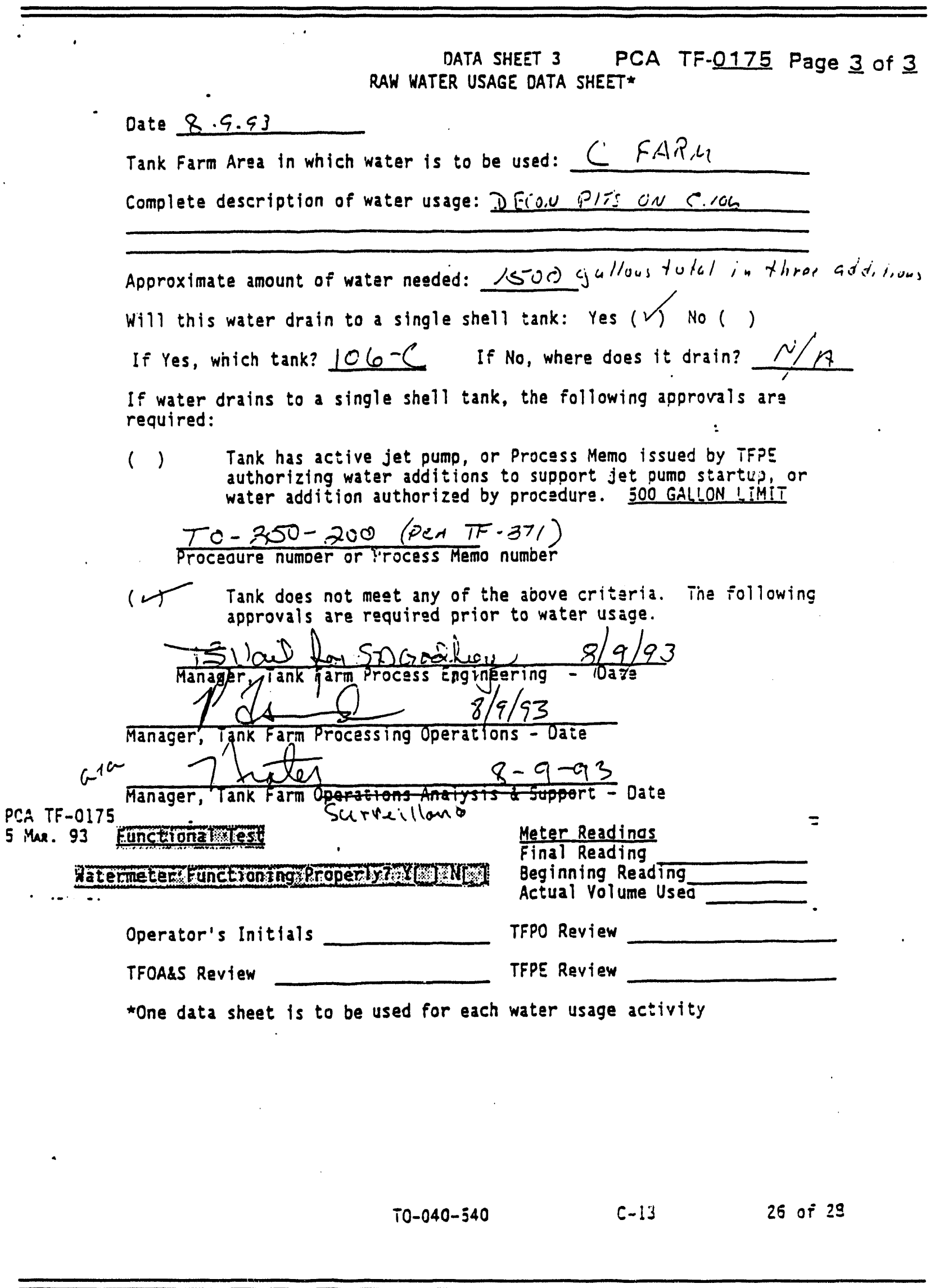




$\star \star \star$ RECORO COPY $\star \star \star$
Page: 1

1. Document Number 2E-93-00613/K CONSTRUCTION WORK Hork Item Title «106-C PIT CLEANOUT \& PAINTING

2. Essential Systems $N / A$

3. Resolution OBJECTIVE: REMOVE AND DISPOSE OF OLD UNUSED/OUT OF SERVICE EQUIPMENT FROM THE PUMP PIT, SLUICE PIT, AND HEEL PIT ON TANK 241-106-C. FOLLOWING THE REMOVAL OF THE EQUIPMENT THE PITS ARE TO $3 E$ DECONNED AND THE SURFACES PREPPED AND PAINTED.

THE FOLLOWING J-4A IS A SUGGESTED WORK PLAN AND ORDER TO PERFORM THE WORK OUTLINED IN THE OBJECTIVE.

4. Impact Level/Approval Requirements 3-5

5. Tech Spec/OSR Requirements/Reference DRAWING H-2-73356 OSD-T-151-00030 "OPERATING SPECIFICATIONS FOR WATCH LIST TANKS"

6. Reference Documents Type

H-2-61967

- $\mathrm{H}-2-37006$

- $\mathrm{H}-2-41192$

V $\mathrm{H}-2-61962$

- $\mathrm{H}-2-41190$

W $\mathrm{H}-2-73877$ SHT. 182

H-2-41194

- TF-002

RuP Rasutieng $7 / 15 / 93$

7. Comments

THE OPERATING PROCEDURES TO-350-200 AND TO-040-540 ARE REQUIRED TO ACCOUNT FOR WATER USAGE WHICH WILL END UP III THE TANK C-106.

8. Retest Requirement $N$

9. Mode $N / A$

10. Retest NONE

11. QC Involvement in Retest NONE

12. PIC BERG,DA

13. PIC Org. $7 C 410$

14. Resolution By Signature

Date

15. Plant Forces Work Review Required $Y$ Number WHC-058-93

16. Approvals Cognizant Engineer 
TYPE B INVESTIGATION REPORT FOR 241-SY-101 PUMP

START AND 241-C-106 PIT CLEANOUT

$\star \star \star$ RECORD COPY $\star \star \star *$

$!$

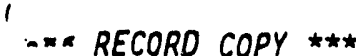

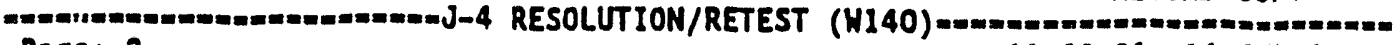

Page: 2

$11: 30: 01 \quad 14$ JUL 1993

1. Document Number 2E-93-00613/K CONSTRUCTION WORK

Work Item Title *106-C PIT CLEANOUT \& PAINTING

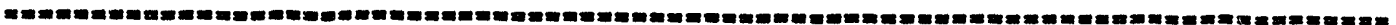

Cognizant Manager $X$ BOYLES, VC

Environmental Assurance N/A

Health/Safety Assurance $X$ JENSEN, CE

quality Assurance N/A

Additional Approvals $X$ SHAW,TN

$05 / 04 / 93$

$07 / 3 / 93$

7. Resources Required

Res Code Description

No. Est Hrs Act Hrs

18. Field Work Complete

19. Retest Satisfactory

20. QC Verify Retest (If Required)

Signature Date

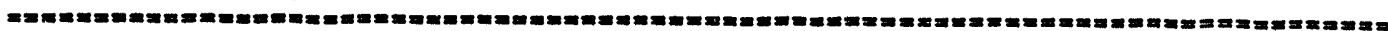

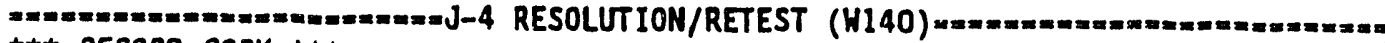




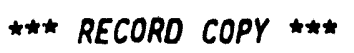

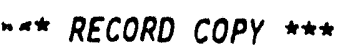

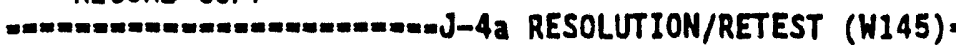

Page: 1

(Cont.)

$11: 30: 25$ 14 JUL 1993

1. Document Number 2E-93-00613/K CONSTRUCTION WORK

Hork Item Title *106-C PIT CLEANOUT \& PAINTING

3. Resolution

WORK PLAN

*1. THE 241-C オANK FARM IS ON "FRESH AIR" AND ALL ENTRANTS WILL REQUIRE "SCKGA" CERTIFICATION.

*2. CURRENT RADIOLOGICAL CONDITIONS WILL REQUIRE TIME/DISTANCE/SHIELDING FOR ALL ACTIVITIES.

*3. A MINIMUM OF FOUR RAD. BOXES SHOULD BE AVAILABLE FOR EQUIPMEN DISPOSAL.

*4. FOUR CONTAINMENT TENT ENCLOSURES WILL BE REQUIRED FOR DECON : AND PAINTING WORK.

*5. A HIGH PRESSURE CLEANING UNIT AND WATER SUPPLY FOR OECONNING WORK WITH WATER FLOW METER.

*6. A 8'X12' TRAILER MODIFIED FOR CARRYING SUPPLIED AIR BOTTLES.

*7. MODIFICATIONS TO THE KEH CRANE TO CARRY SUPPLIED AIR BOTTLES.

*8. THE PIC/SUPERVISOR OF THE JOB OR TASK SHALL PERFORM THE FOLLOWING:

A. IS HAZARDOUS WASTE GENERATED FROM OR BY THIS JOB?

YES LHO/NA UH, JU.

B.ARE THE APPROPRIATE WASTE CONTAINERS AVAILABLE TO PERFORM THIS TASK AND ARE THEY OY THE JOB SITE?

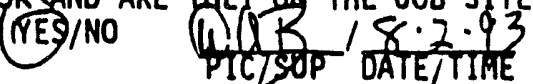

C. DAILY: PIC/SUPERVISOR TO RECORD ON THE J-5 THAT ALL OF THE WASTE GENERATED FOR THAT DAY HAS BEEN PROPERLY DISPOSED OF. SIGN AND DATE THE J-5.

D.AT THE COMPLETIONOF THE JOB: PIC/SUPERVISOR RECORD ON THE J-5 THAT THE JOB SITE HAS BEEN CLEANED AND ALL WASTE HAS

BEENPROPERLY DISPOSED OF. OPERATIONS TO VERIFY AND SIGN THE J-5.

STEP 1. PERFORM A RADIOLOGICAL AND CONTAMINATION SURVEY OF ALL SURFACE AREAS AFFECTED IN THIS WORK. SNIFFER REQUIRED TO SNIFF THE AREA AT THIS POINT.

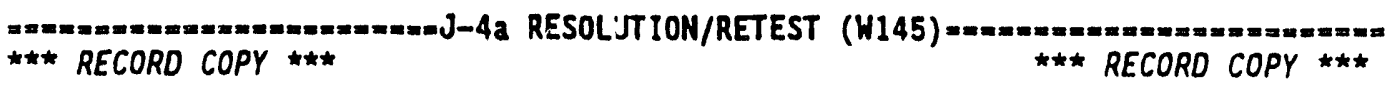


TYPE B INVESTIGATION REPORT FOR 241-SY-101 PUMP

START AND 241-C-106 PIT CLEANOUT

*** RECORO COPY ***

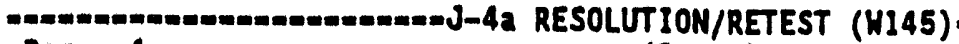

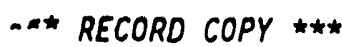

Page: 4

(Cont.)

$11: 30: 25 \quad 14$ JUL 1993

1. Document Number 2E-93-00613/K CONSTRUCTION WORK

Work Item Title *106-C PIT CLEANOUT \& PAINTING

smummomm

STEP 21. REMOVE ALL ENCLOSURES AND DISPOSE OF IN APPROPRIATE

CONTAINERS. REMOVE ALL TUBE BLOCK FROM THE FARM. ALL EQUIPMENT

USED IN THIS EFFORT TO BE REMOVED FROM THE FARM TO SATTELITE

STORAGE OR OTHER AREAS DESIGNATED BY OPERATIONS.

STEP 22. OISPOSE OF ALL HAZARDOUS MATERIALS IN THE APPROPRIATE CONTAINERS AT THE SATALITE ACCUMULATION AREA AND NOTIFY OPERATIONS WHEN THE CONTAINERS ARE FULL. 


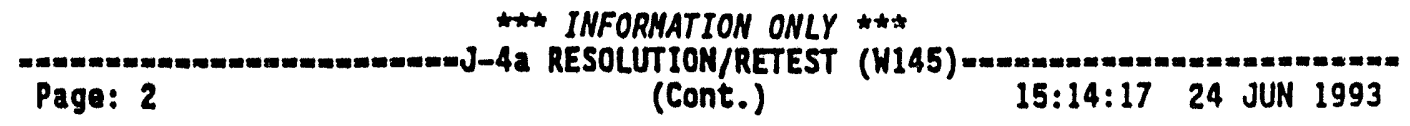

1. Document Number 2E-93-00613/K CONSTRUCTION WORK Worl: Item Title *106-C PIT CLEANOUT \& PAINTING

STEP 2. RIGGING SUPERVISORS TO PERFORM A VISUAL INSPECTION OF THE COVER BLOCK LIFTING BAILS PRIOR TO PERFORMING THE PICK.

NOTE: IF LIFTING BAILS ARE FOUND TO BE SUSPECT AS DETERMINED BY THE RIGGING SUPERVISOR'S VISUAL INSPECTION, THE COVER BLOCK LIFTING BAILS WILL BE PRE LOAD TEST M.T. INSPECTED, LOAD TESTED AT 125\% ESTIMATED BLOCK WEIGHT, AND POST LOAD TEST M.T. INSPECTED.

VISUAL ACCEPTANCE WILL BE BASED ON NO VISIBLE DISTORTION, CRACKING, OR REDUCTION OF ORIGINAL CROSS SECTIONAL THICKNESS.

M.T. INSPECTION ACCEPTANCE, IF NECESSARY, WILL BE BASED ON NO CRACKS IN EXCESS OF $1 / 4^{n}$. IF MULTIPLE CRACKS UNDER $1 / 4^{\prime \prime}$ ARF. FOUND IN THE BEND RADIUS OF A BAIL, THE ENGINEER WILL BE NOTIFIED.

STEP 3.HOLD PRE JOB SAFETY MEETING PRIOR TO BEGINNING WORK.

STEP 4.WORK TO BE PERFORMED IN THE FOLLOWING SEQUENCE:

1. PIT 06 $\rightarrow$ - B

2. PIT 06-C

Remous inserlation from pit + pit covers dispesal STEP 5 HOLD POINT: HPY SHALL VERIFY A GROUND COVERING IS IN PLACE FOR REMOVED COVERBLOCKS TO PASS OVER PRIOR TO BREACHING PIT AREA. HPT DATE:

STEP 6. REMOVE COVER BLOCKS SHALL BE PLACED ON GROUND COVERING AND WRAPPED FOR CONTAMINATION CONTROL.

STEP 7. A CONTAINMENT COVER SHALL BE PLACE OVER PIT AREA UPON INDIVIDUAL COVERBLOCK REMOVAL.

STEP 8. HOLD POINT: A CONTAINMENT TENT SHALL BE ERECTED OVER PIT CONTAINMENT COVERS AND PIT AREA. A HP SUPERVISOR SHALL VERIFY THE ADEQUACY OF THE CONTAINMENT PRIOR TO USAGE. HP SUPERVISOR , DATE:

STEP 9. REMOVE CONTAINMENT COVERS AND STORE WITHIN CONTAINMENT TENT LATER USAG!.

STEP 10.LIGHTLY MOISTEN INNER PIT WALLS ANO FLOOR PRIOR TO PERFORMING DECONTAMINATION REMOVAL OF LOOSE SEDIMENT WITHIN PIT AREA. LOOSE SEDIMENT SHOULD BE INSERTED INTO OPEN RISER OR PIT FLOOR DRAIN AS DETERMINED BY PIC.

STEP 11.AFTEK MAJOR PORTIONS OF SEDIMENT HAS BEEN REMOVED APPLY 

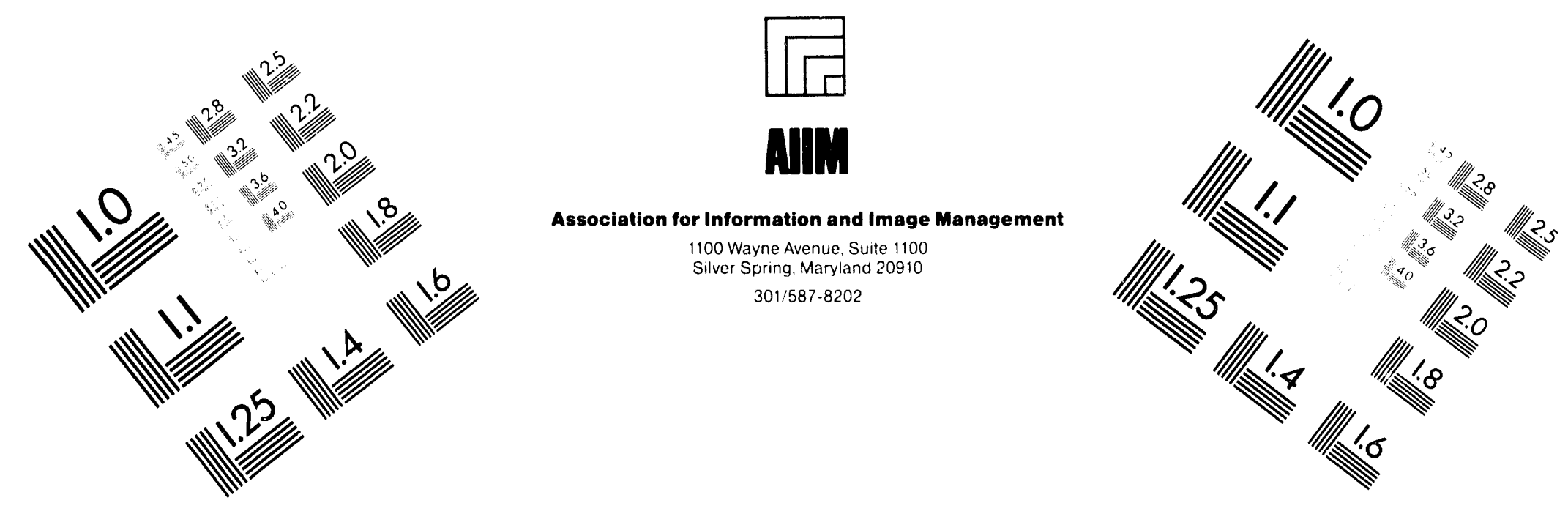

\section{Centimeter}

|

Inches
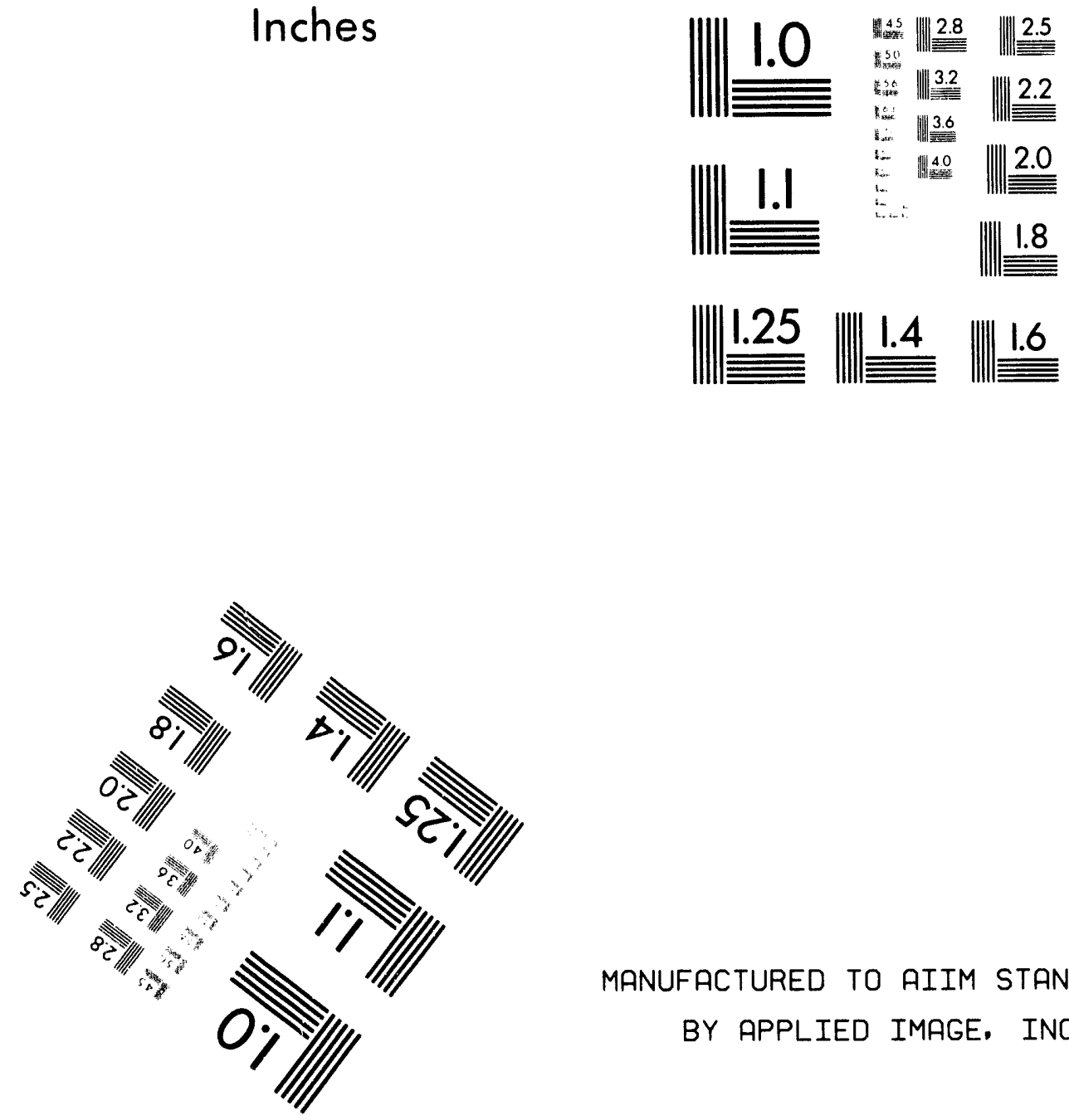

MANUFACTURED TO AIIM STANDARDS

BY APPLIED IMAGE. INC.

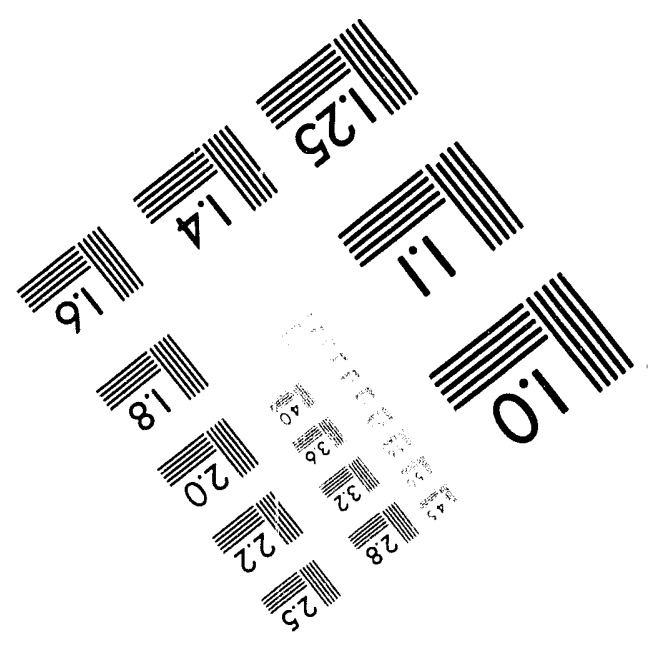



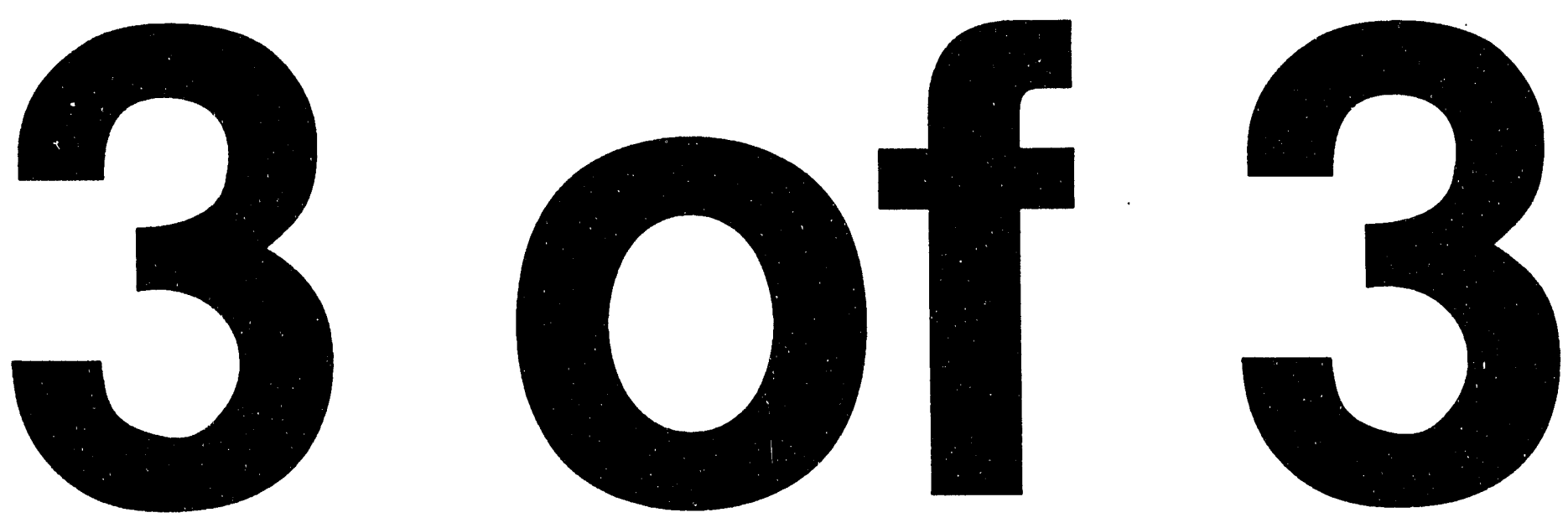


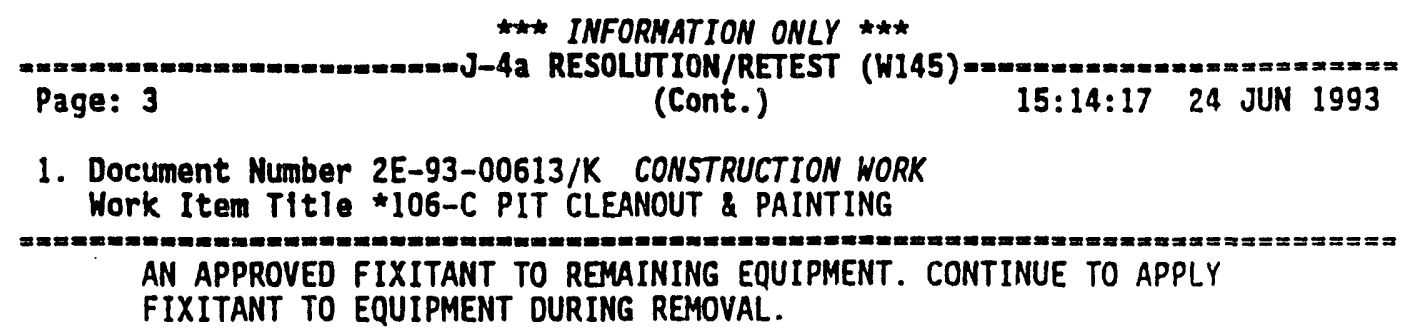

STEP 12. REMOVE ALL EXCESS EQUIPMENT LOCATED INSIDE THE PIT AND PLACE INTO RAD BOX FOR DISPOSAL. NOTE: PUMPS ARE TO REMAIN IN PLACE FOR FUTURE REMOVAL.

STEP 13. ERECT A SECONDARY CONTAINMENT TENT OVER EXISTING PIT If needed for CONTAINMENT FOR PIT FOR ADOITIONAL DECONNING AND PAINTING. Temp \& Work

STEP 14.APPLY FIXITANT TO INTERIOR WALLS AND SURFACES OF PIT CONTAINMENT TENT PRIOR TO DISMANTLING. THE CONTAINMENT TENT SHALL BE COLLAPSED AND DISPOSED INTO APPROPRIATE CONTAINER. HPT , DATE:

STEP 15.HPT SHALL PERFORM A DOSE RATE SURVEY AROUND THE OUTER EDGE OF INNER PIT AREA. HPT SHALL PERFORM A CONTAMINATION SURVEY OF INNER PIT WALLS AND FLOORS FOR A BASELINE ASSESSMENT OF DECONTAMINATION LEVELS. HPT RATE , CONTAMINATION LEVELS B́/G , DOSE

STEP 16.PERFORM DECONTAMINATION OF INNER PIT AREA USING A HIGH PRESSURE SYSTEM.

STEP 17.HPT SHALL OBTAIN LARGE AREA SMEARS(300 CM2) FOR A DECON ASSESSMENT. HPT $B / G$ - DATE: , SMEARABLE LEVELS

STEP 18.DECONTAMINATION EFFORTS SHALL BE DISCONTINUED WHEN REMOVABLE CONTAMINATION LEVELS FROM HPT SMEAR SWIPES ARE LESS THAN 50\% OF THE LOWEST READING TAKEN.

NOTE: WATER ADDITION TO THE TANK IS LIMITED TO A MAXIMUM OF 79 INCHES FROM TANK BOTTOM. CONTACT SYSTEMS ENGINEERING BEFORE AND AFTER COMPLETION OF ANY WATER ADDITION FOR DECONNING.

$$
\text { If possible before painting }
$$

STEP 10. PREPARE SURFACES OF THE PIT INTERIOR AND APPLY AMERCOAT 187 PRIMER WHERE REQUIRED, AND TWO COATS OF AMERCOAT 33 WHITE.

STEP 11. REMOVE ALL ENCLOSURES AND OISPOSE OF IN APPROPRIATE CONTAINERS. REMOVE ALL TUBE BLOCK FROM THE FARM. ALL EQUIPMENT USED IN THIS EFFORT TO BE REMOVED FROM THE FARM TO SATTELITE STORAGE OR OTHER AREAS DESIGNATED BY OPERATIONS.

STEP 12.DISPOSE OF ALL HAZARDOUS MATERIALS IN THE APPROPRIATE CONTAINERS AT THE SATALITE ACCUMULATION AREA AND NOTIFY OPERATIONS WHEN THE CONTAINERS ARE FULL. 
TYPE B INVESTIGATION REPORT FOR 241-SY-101 PUMP START AND 241-C-106 PIT CLEANOUT

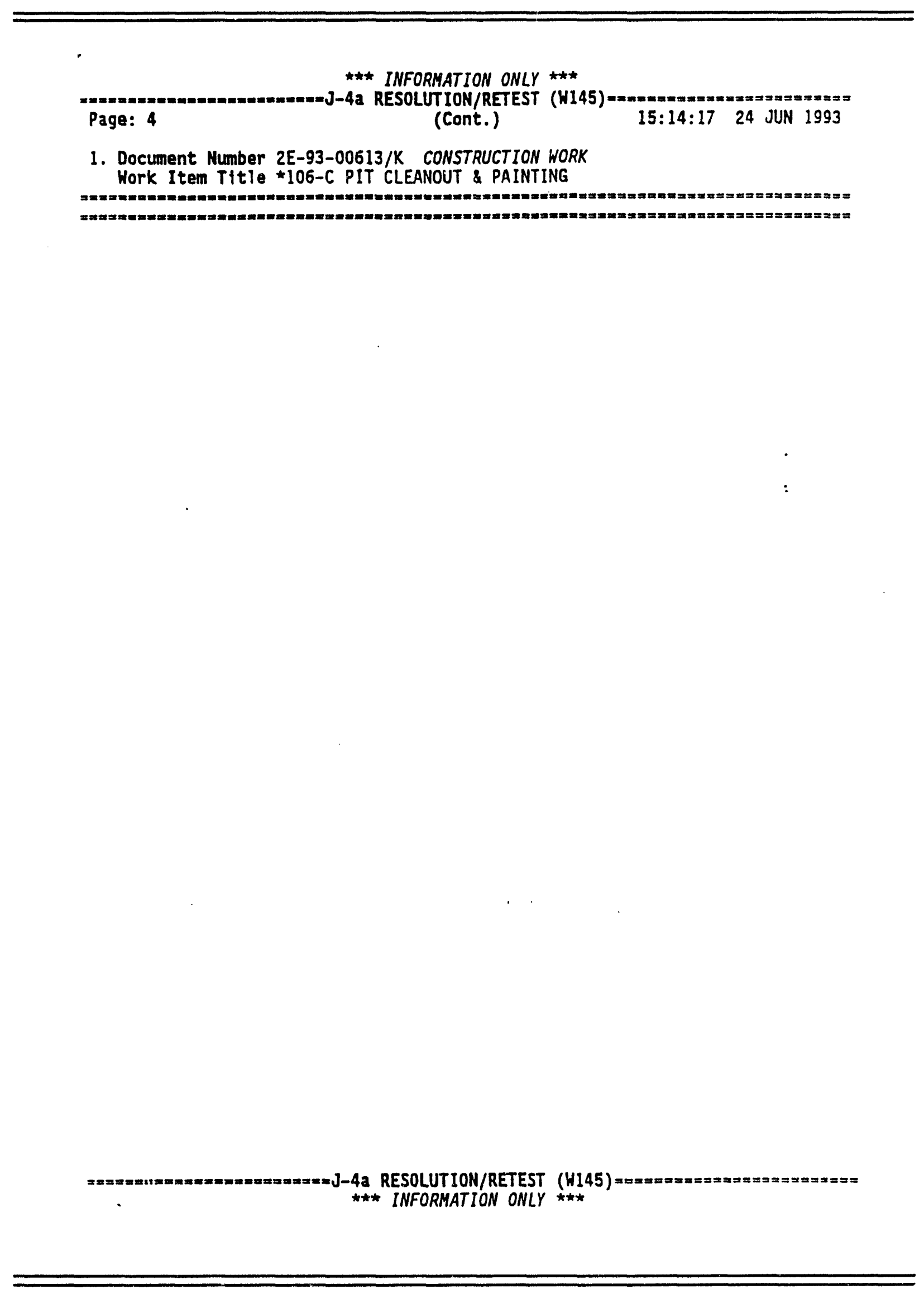




\section{TYPE B INVESTIGATION REPORT FOR 241-SY-101 PUMP START AND 241-C-106 PIT CLEANOUT}

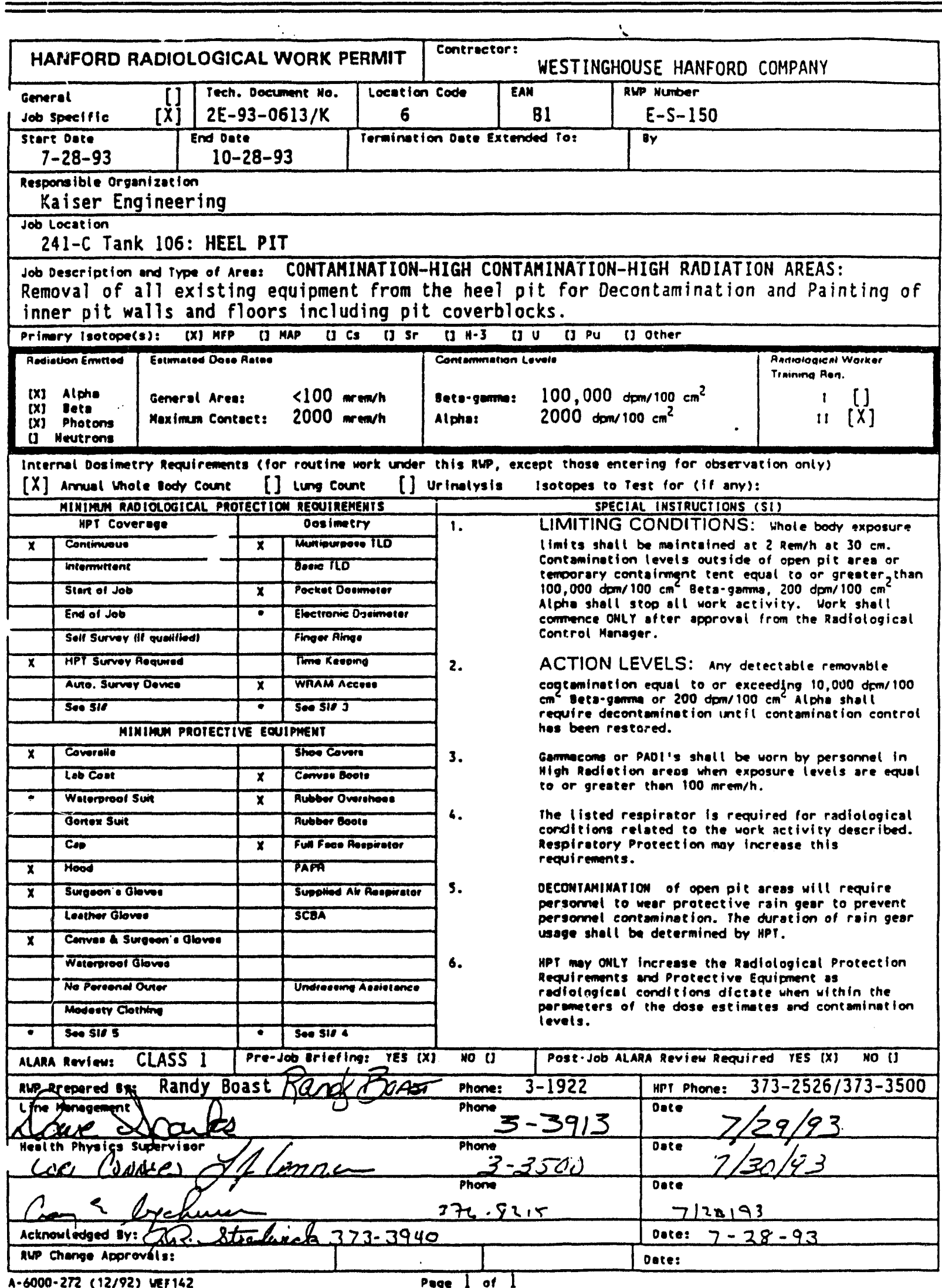




\section{TYPE B INVESTIGATION REPORT FOR 241-SY-101 PUMP START AND 241-C-106 PIT CLEANOUT}

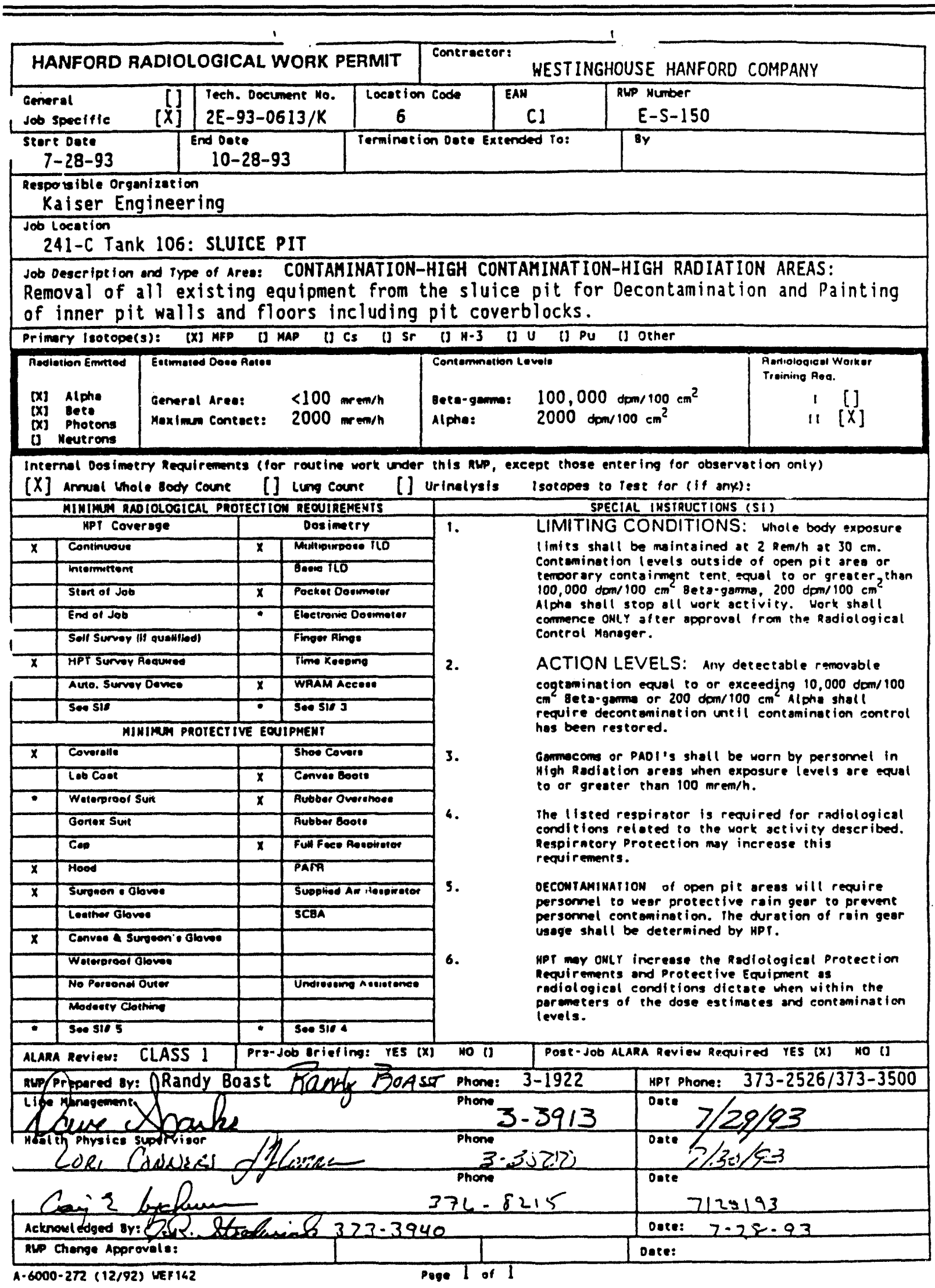




\section{TYPE B INVESTIGATION REPORT FOR 241-SY-101 PUMP START AND 241-C-106 PIT CLEANOUT}

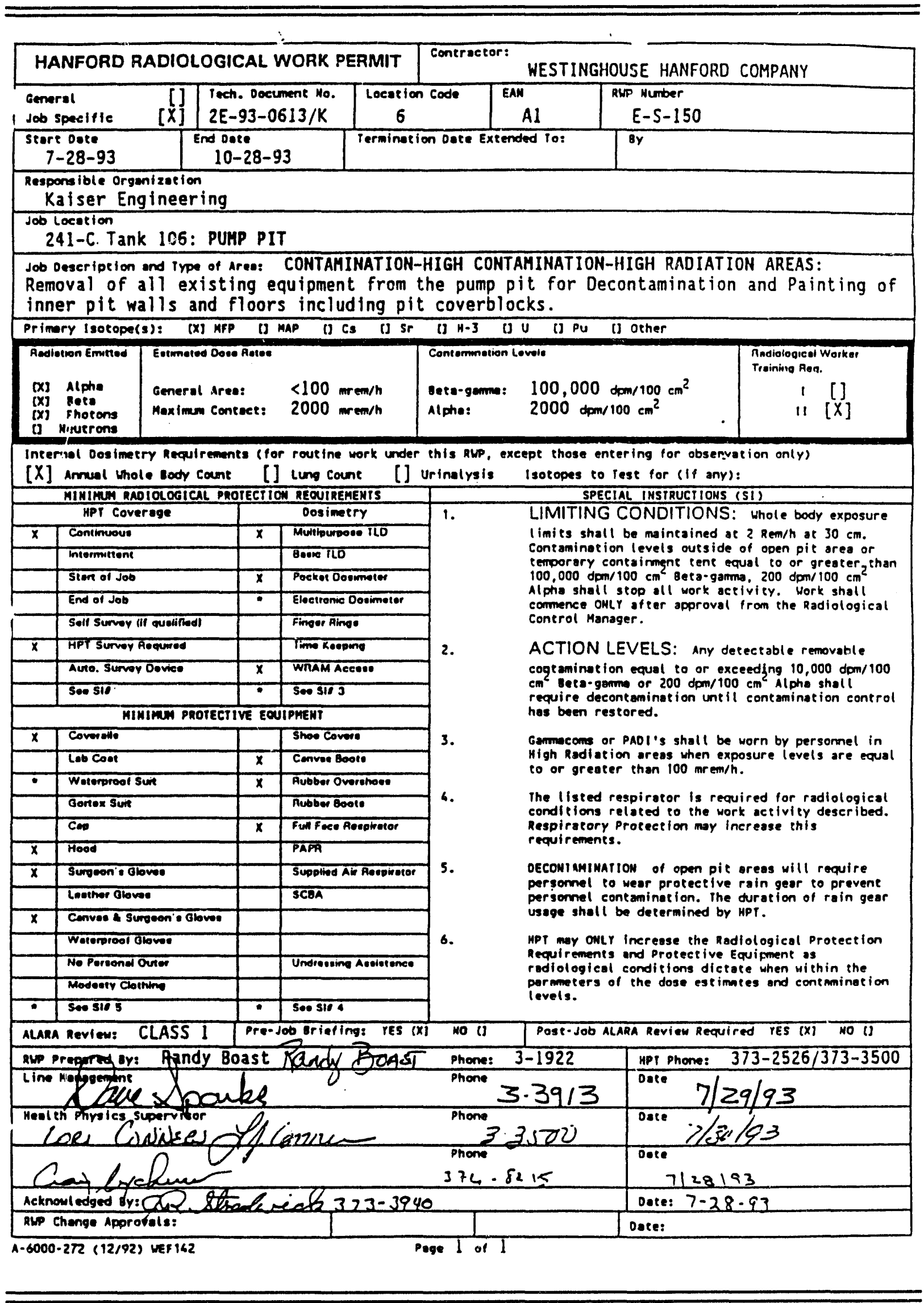




\section{TYPE B INVESTIGATION REPORT FOR 241-SY-101 PUMP START AND 241-C-106 PIT CLEANOUT}

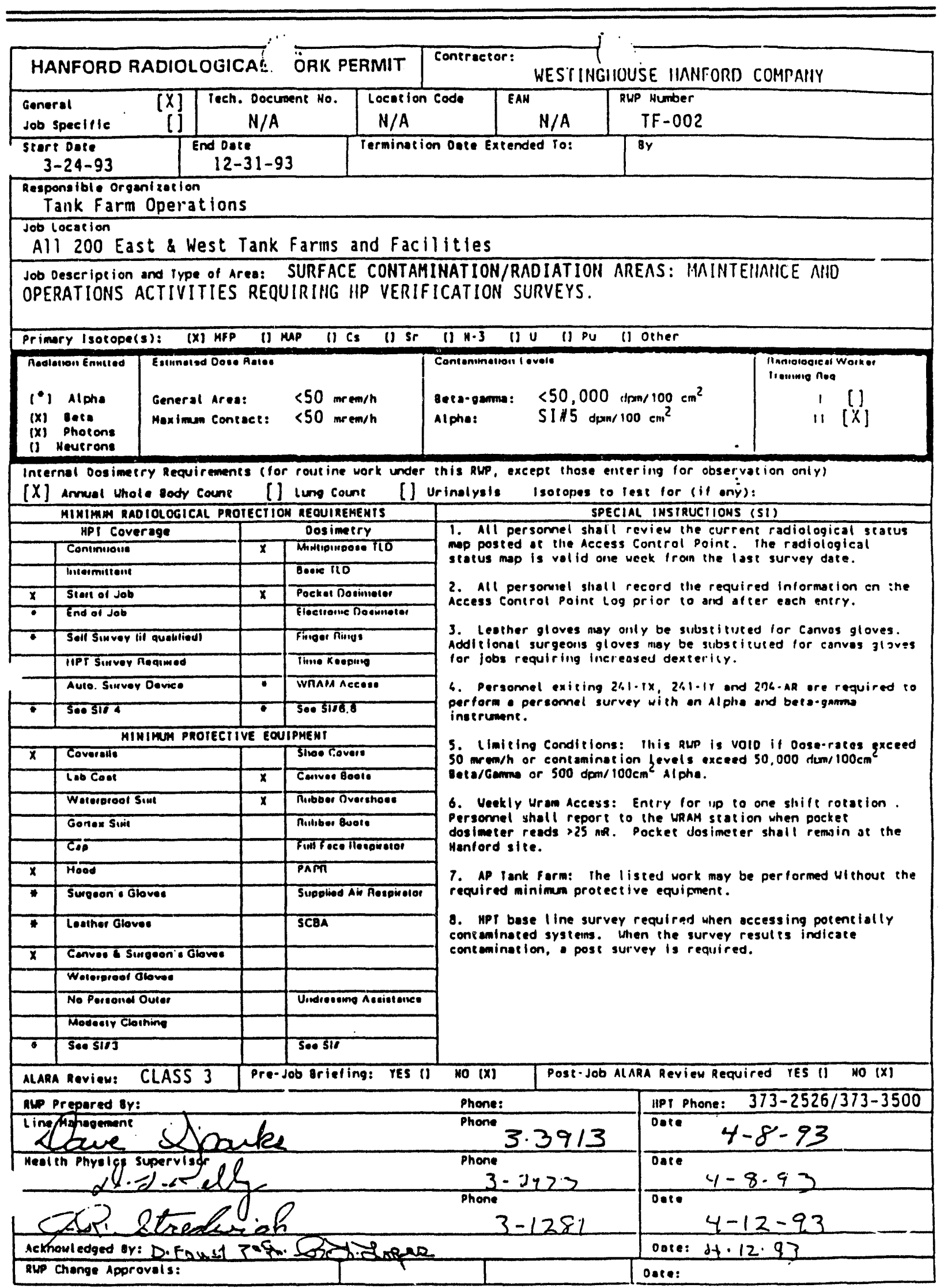


TYPE B INVESTIGATION REPORT FOR 241-SY-101 PUMP START AND 241-C-106 PIT CLEANOUT

\section{ALARA MANAGEMENT WORKSHEET}

$$
2 E-93-00613 / K
$$

A) COVER BLOCKS WILL BE SET AWAY FROM PITS INTO A CONTAINMENT TENT TO BE WORKED ON.

B) PITS WILL BE DECONTAMINATED/CLEANED AND PAINTED AFTER REMOVING EXCESS JUMPERS AND EQUIPMENT.

C) LEAD BLANKETS WILL BE HUNG FOR SHIELDING AS NECESSARY AND PRACTICAL TO REDUCE DOSE RATES FROM THE PITS TO PERSONNEL WORKING AROUND THE PITS.

D)

E) CONTAINMENT TENTS ARE TO BE USED OVER THE PITS AND COVER BLOCKS.

F)

G) YES. SUFFICIENT WASTE CONTAINERS HAVE BEEN ORDERED TO SEGREGATE AND PROPERLY DISPOSE OF ALL WASTE.

H) NUMBER OF PERSONNEL HAS BEEN REDUCED TO MINIMUM REQUIRED TO SAFELY PERFORM THE TASKS.

I) NO TOOLS OR MATERIALS ARE STORED AT THE JOB SITE.

J) ALL ENTRY / EGRESS ROUTES ARE IDENTIFIED.

- collective dose cannot be estimated until pits are opened due to LACK OF HISTORICAL DATA. 


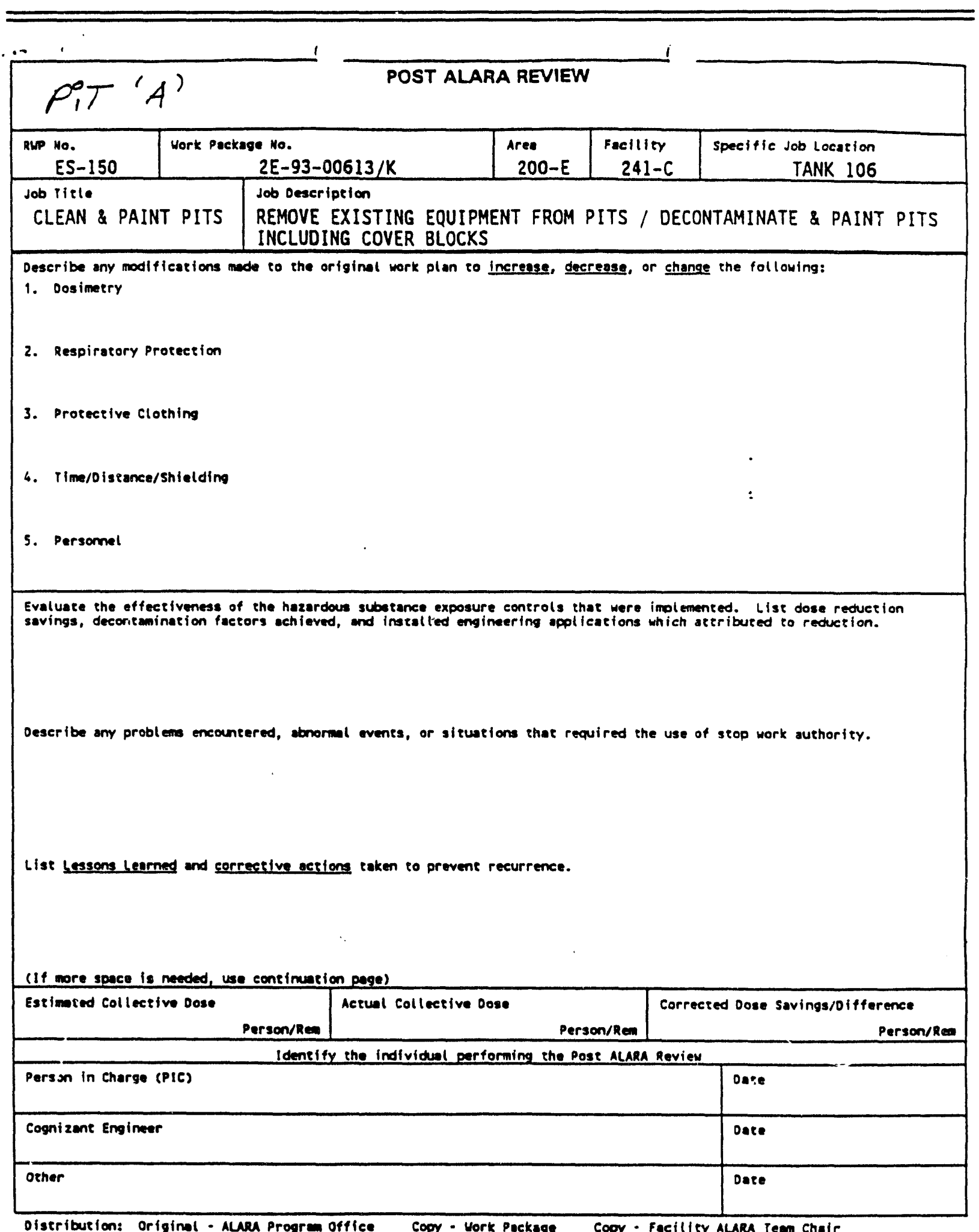

Distribution: Orfoinal - ALARA Progrem office Copy - Hork Packege Copy - Facilley ALARA Team Chair 
TYPE B INVESTIGATION REPORT FOR 241-SY-101 PUMP

START AND 241-C-106 PIT CLEANOUT

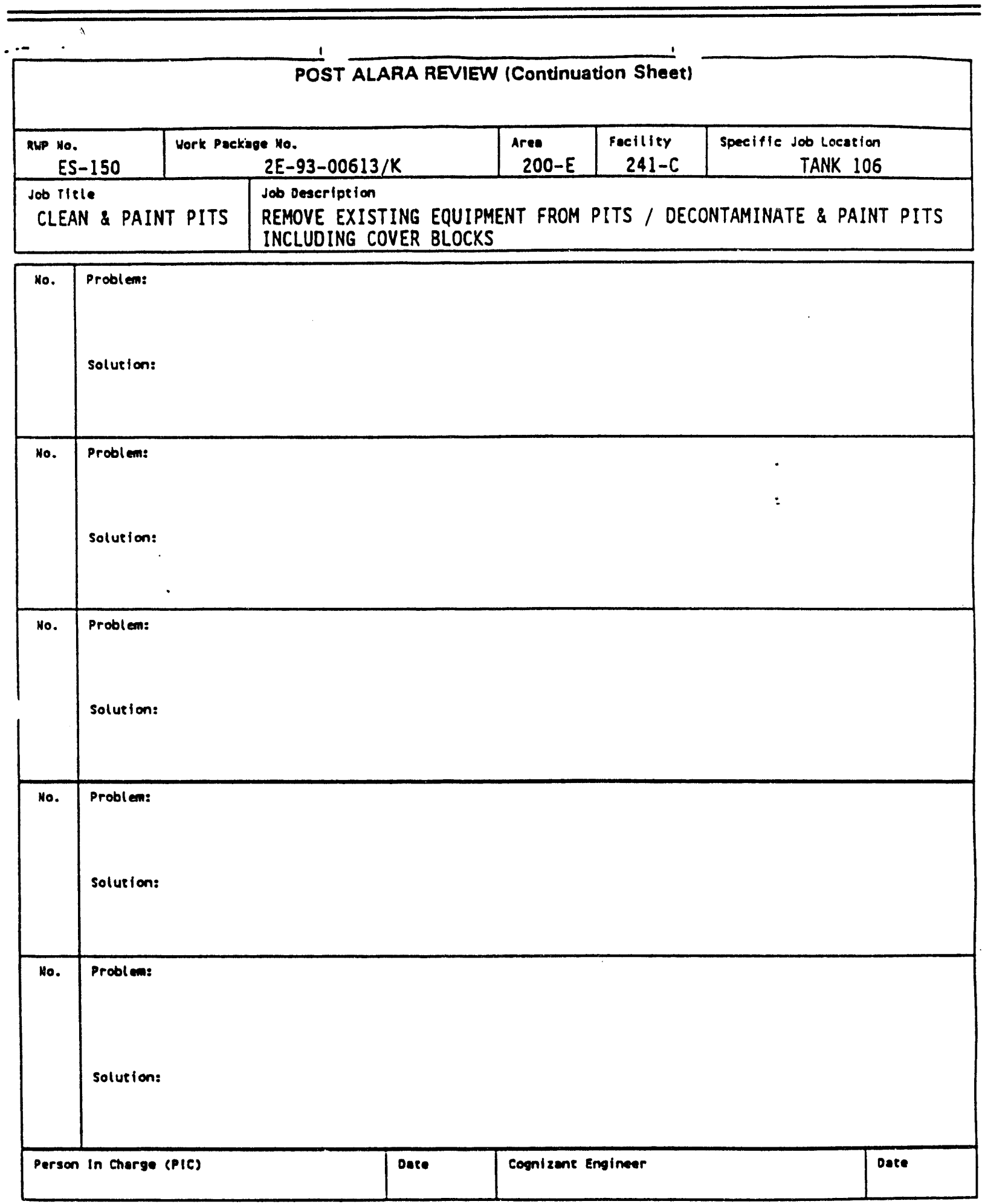

Page 2 of 2 
TYPE B INVESTIGATION REPORT FOR 241-SY-101 PUMP

START AND 241-C-106 PIT CLEANOUT

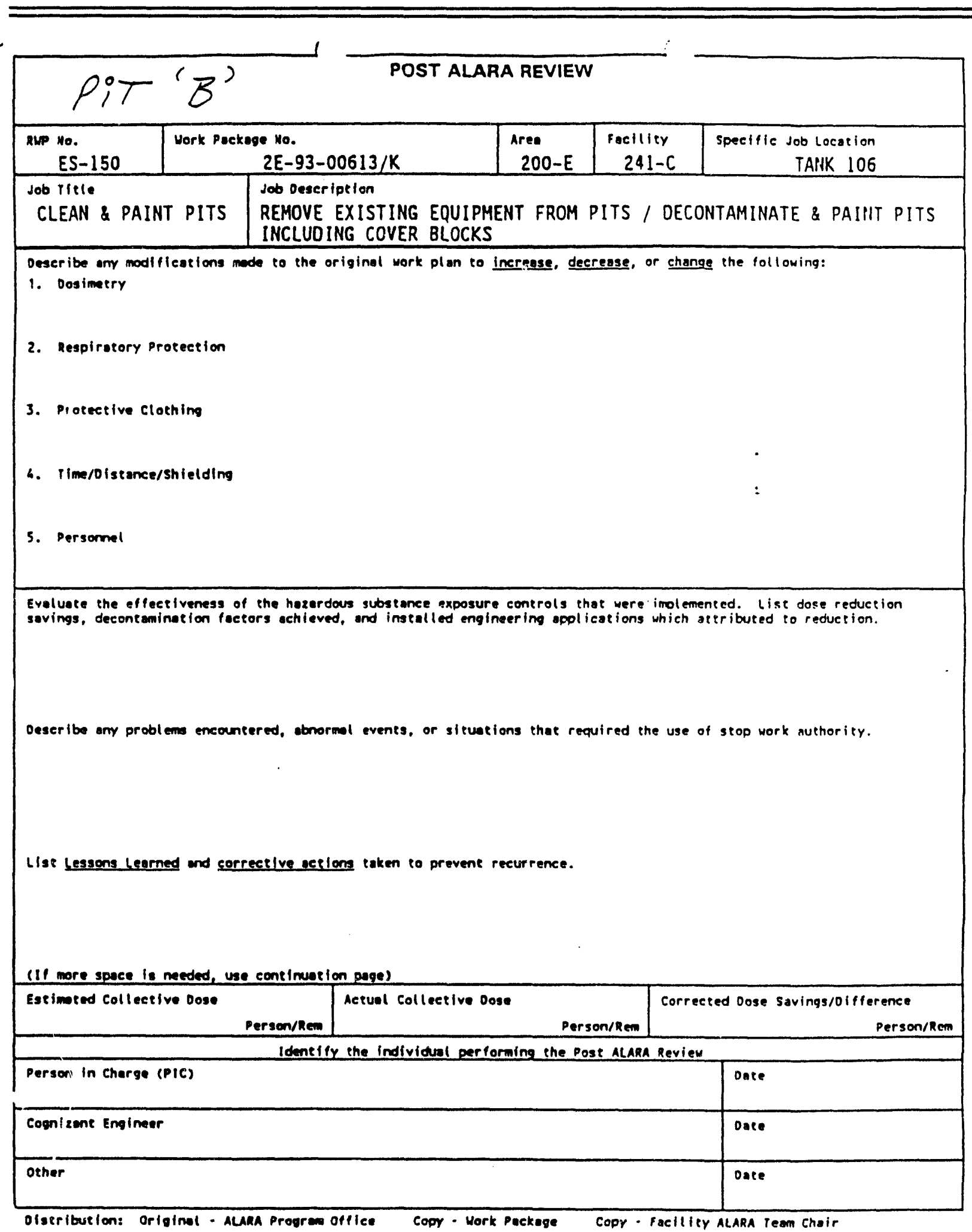


TYPE B INVESTIGATION REPORT FOR 241-SY-101 PUMP

START AND 241-C-106 PIT CLEANOUT

JST ALARA REVIEW Continuation!

set

\begin{tabular}{|c|c|c|c|c|c|}
\hline $\begin{array}{l}\text { RWP No. } \\
\text { ES-150 }\end{array}$ & Work Pack & $2 E-93-00613 / K$ & $\begin{array}{l}\text { Ares } \\
200-E\end{array}$ & $\begin{array}{r}\text { Fecility } \\
241-C \\
\end{array}$ & $\begin{array}{r}\text { Specific Job Locasion } \\
\text { TANK } 106 \\
\end{array}$ \\
\hline \multicolumn{2}{|l|}{ Job ritle } & \multicolumn{4}{|l|}{ Job oescripetion } \\
\hline \multicolumn{2}{|c|}{ CLEAN \& PAINT PITS } & \multicolumn{4}{|c|}{$\begin{array}{l}\text { REMOVE EXISTING EQUIPMENT FROM PITS / DECONTAMINATE \& PAINT PITS } \\
\text { INCLUDING COVER BLOCKS }\end{array}$} \\
\hline
\end{tabular}

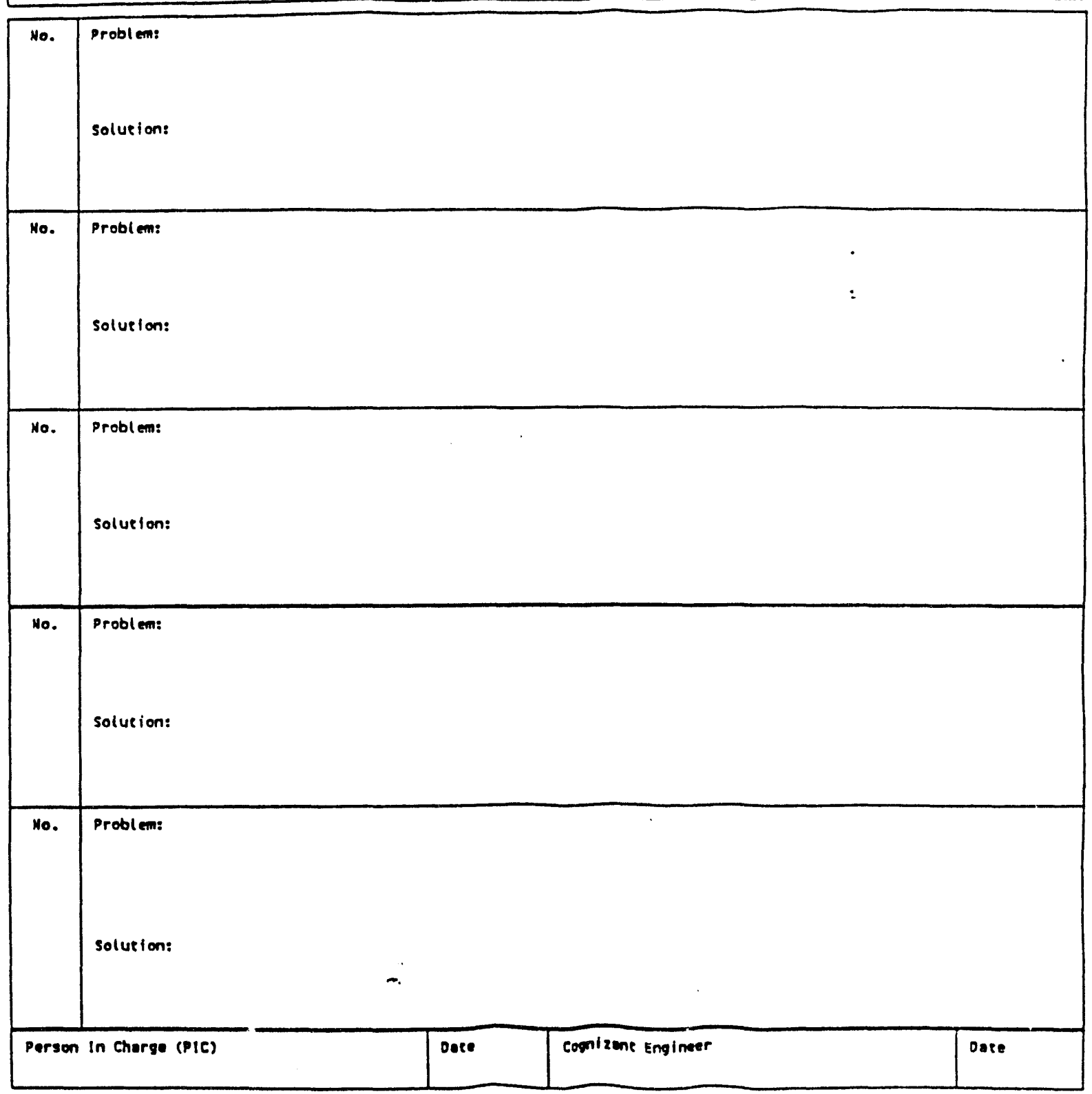




\section{TYPE B INVESTIGATION REPORT FOR 241-SY-101 PUMP START AND 241-C-106 PIT CLEANOUT}

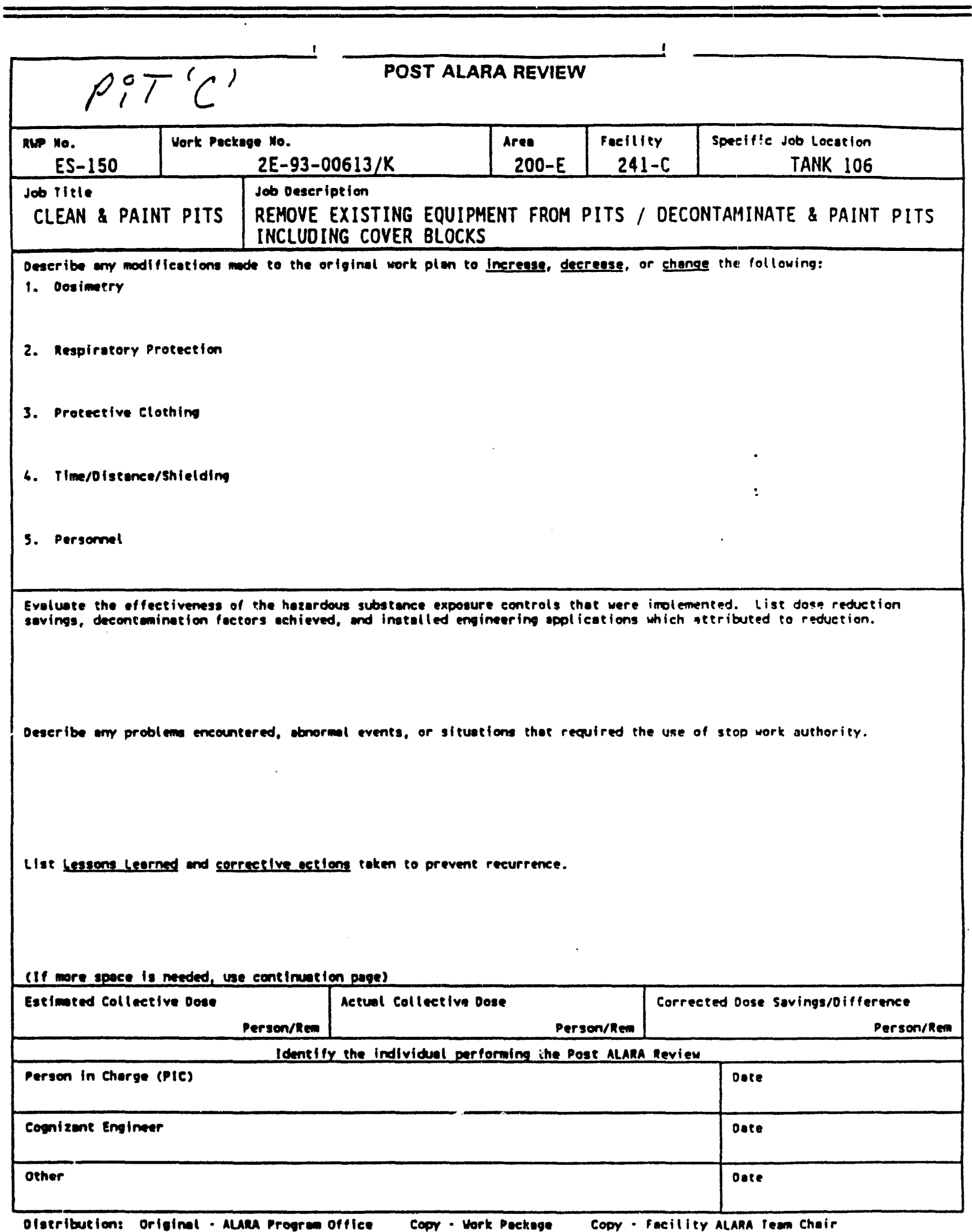


TYPE B INVESTIGATION REPORT FOR 241-SY-101 PUMP START AND 241-C-106 PIT CLEANOUT

POST ALARA REVIEW (Continuation Sheet)

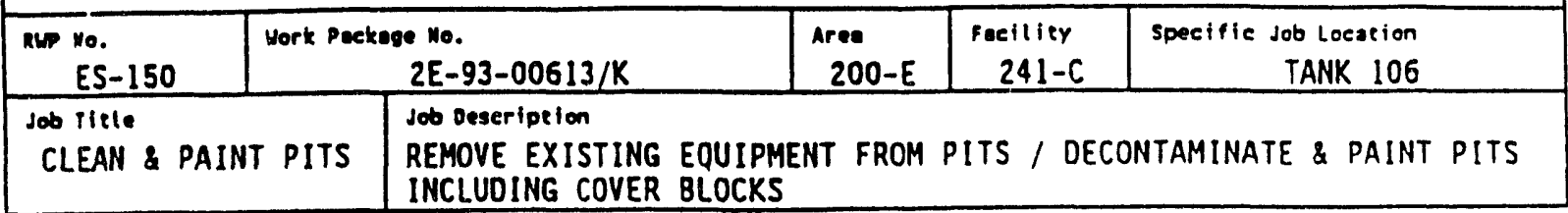

\begin{tabular}{|c|c|c|c|c|c|}
\hline No. & $\begin{array}{l}\text { Problem: } \\
\text { Solution: }\end{array}$ & & & & \\
\hline No. & $\begin{array}{l}\text { Problem: } \\
\text { Solution: }\end{array}$ & & & : & \\
\hline No. & $\begin{array}{l}\text { Problem: } \\
\text { Solution: }\end{array}$ & & & & \\
\hline No. & $\begin{array}{l}\text { Problem: } \\
\text { Solution: }\end{array}$ & & & & \\
\hline no. & $\begin{array}{l}\text { Problem: } \\
\text { Solution: }\end{array}$ & & & & \\
\hline \multicolumn{2}{|c|}{ Person in Cherge (PIC) } & oote & Cognizent Engineer & & Dote \\
\hline
\end{tabular}




\section{TYPE B INVESTIGATION REPORT FOR 241-SY-101 PUMP \\ START AND 241-C-106 PIT CLEANOUT}

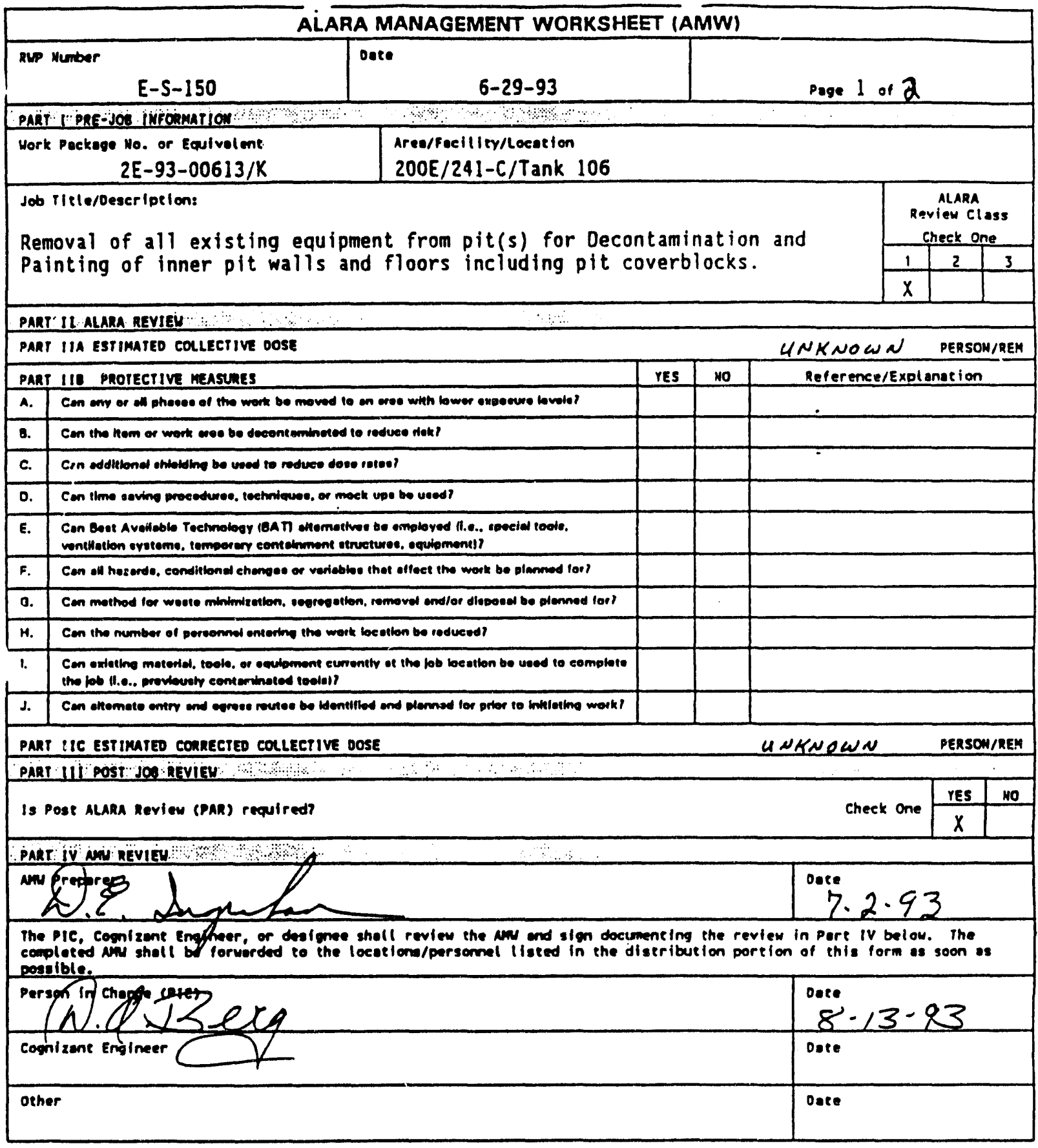

olstainuriow: Origind - ouss central flles facilley alaka tewn choir
ALAMA Progrem Office

Work Pockege 
TYPE B INVESTIGATION REPORT FOR 241-SY-101 PUMP START AND 241-C-106 PIT CLEANOUT

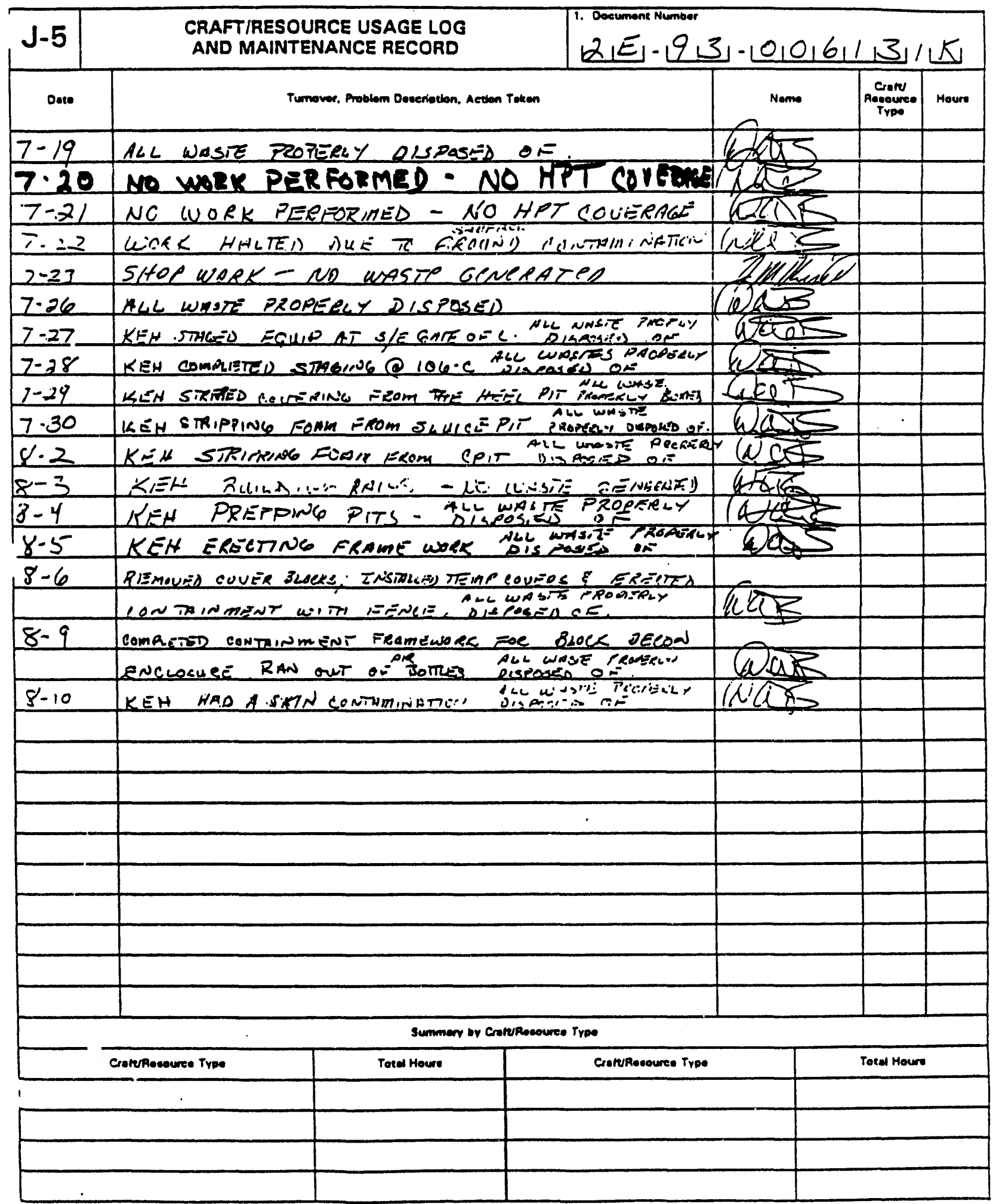




\section{TYPE B INVESTIGATION REPORT FOR 241-SY-101 PUMP START AND 241-C-106 PIT CLEANOUT}

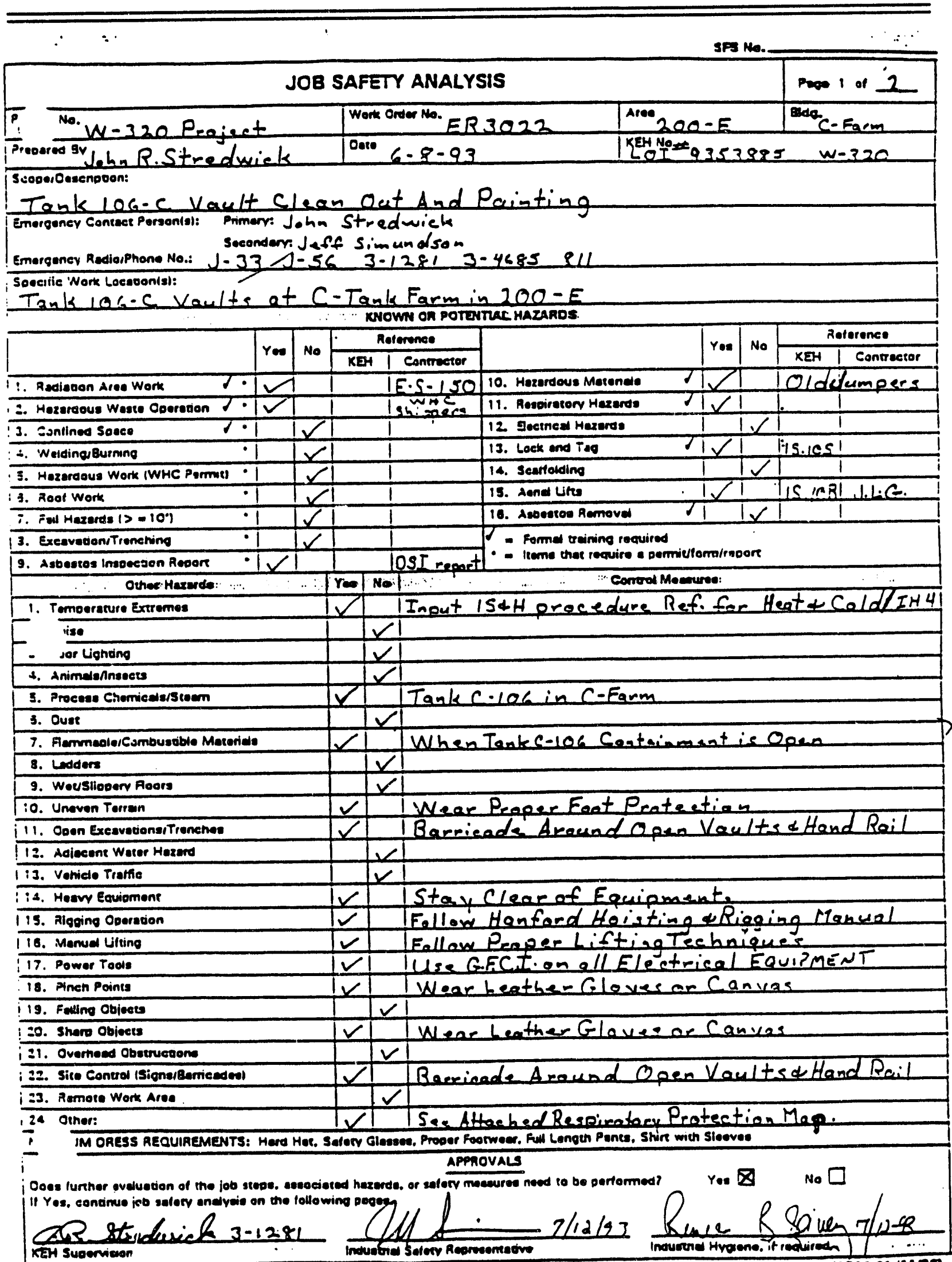


TYPE B INVESTIGATION REPORT FOR 241-SY-101 PUMP

START AND 241-C-106 PIT CLEANOUT

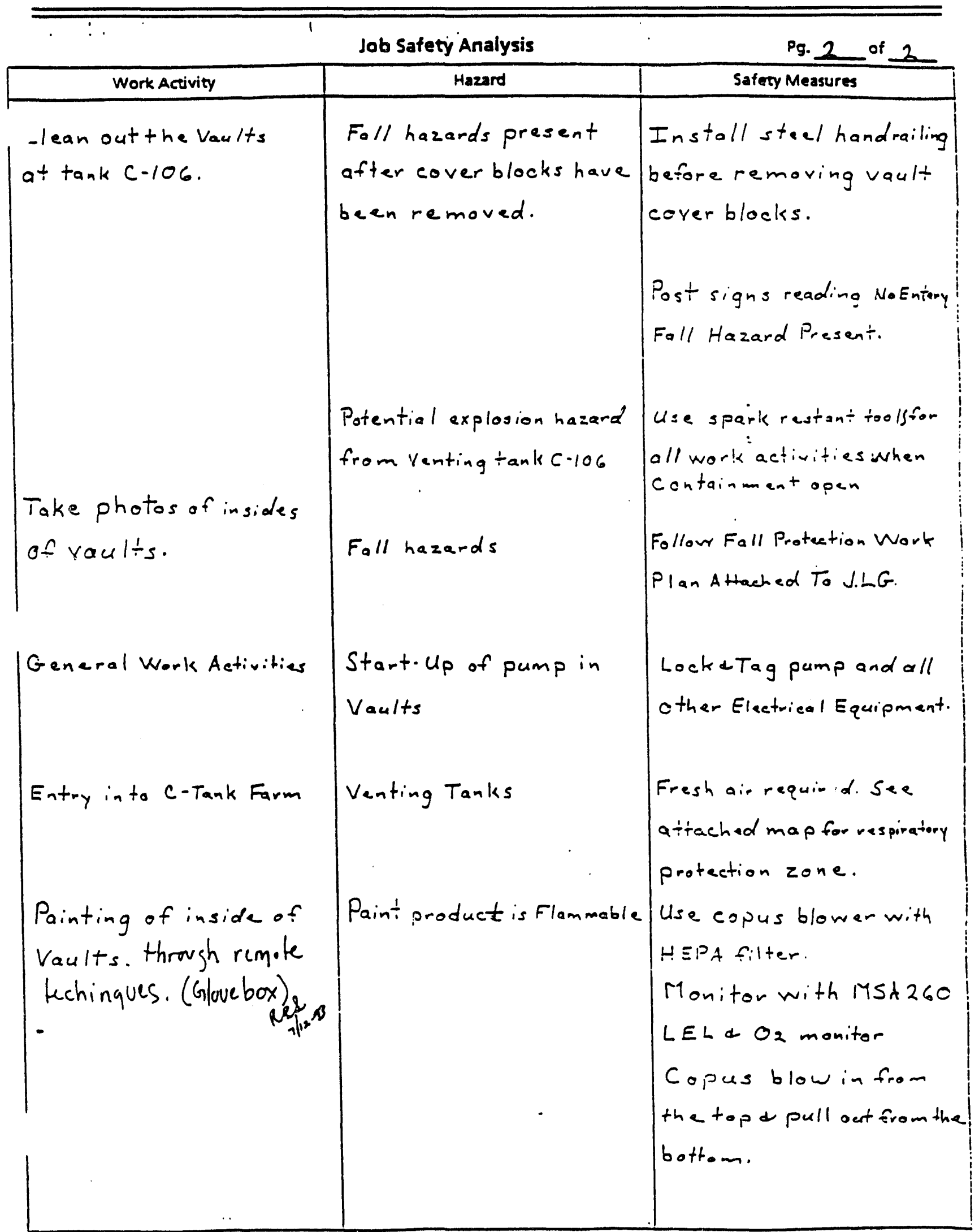


DON'T SAY IT - Write It!

TO: John Stredwick
DATE: JUIY T, 1993

FROM: David Berg Telephone: 373-496)

SUBJECT: ASBESTOS STATEMENT FOR 106-C PIT CLEANOUT

Work package 2E-93-00613/K has been issued to clean out the pits on Tank 24l106-C. This work is not projected to encounter any asbestos containing materials. If any asbestos containing materials are encountered, stop work immediately and contact the Major Maintenance PIC.

Work will resume on direction of the PIC after the area has been assessed and the proper clean up initated. 
TYPE B INVESTIGATION REPORT FOR 241-SY-101 PUMP START AND 241-C-106 PIT CLEANOUT

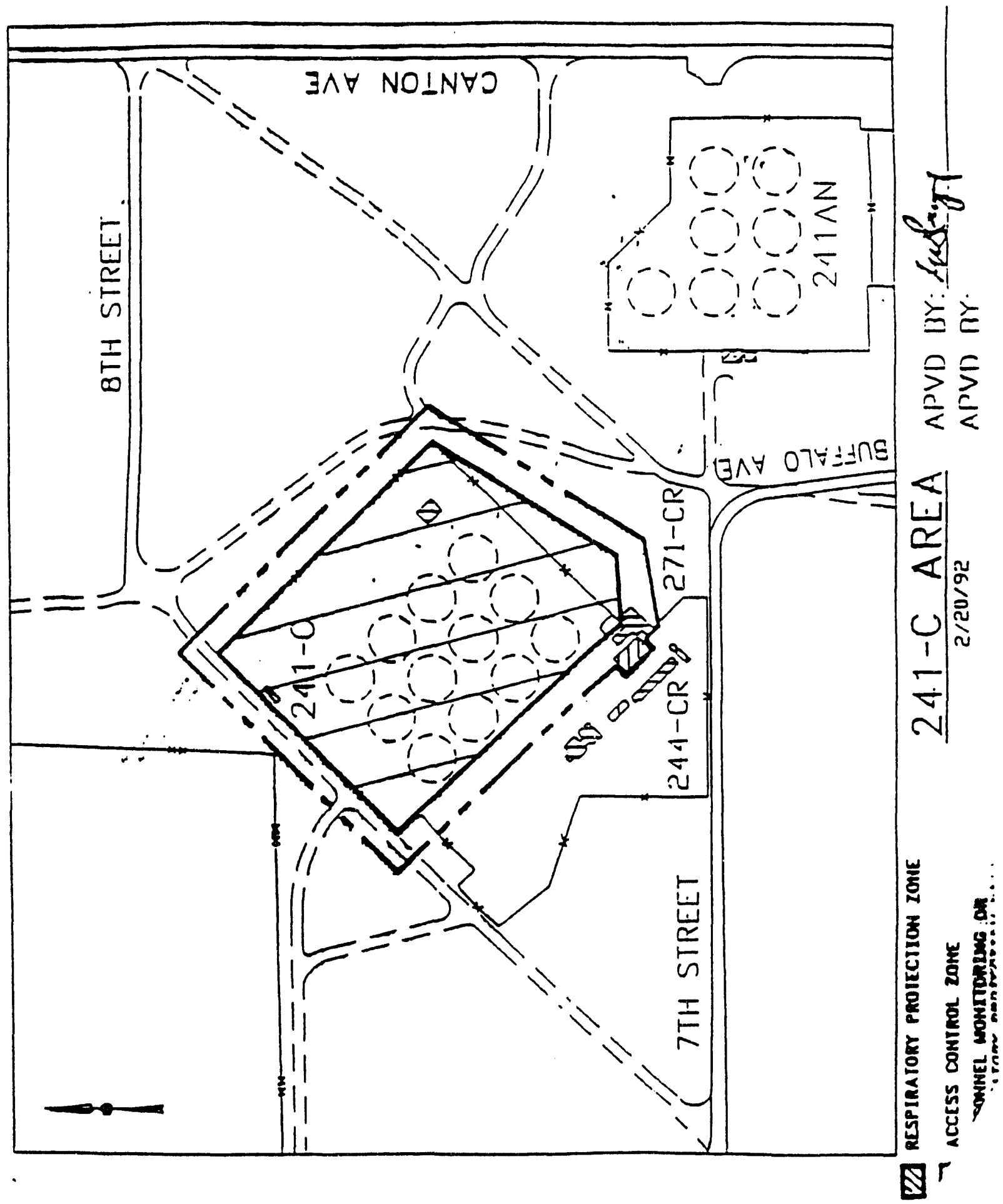


DON'T SAY IT --- Write It!

TO Oistribution

cc:
DATE October 7, 1992

FROM J. P. simundson 4 .

I have developed a standardized Fall Protection Work Plan for operating boom supported elevated work platforms (JLG type aerial lifts). Attached is a copy of this plan. This Fall Protection Work $P l a n$ has been placed with the operation manual on all KEH owned JLG lifts to provide consistency during pre-job planning. Employees utilizing the JLG lift must sign the attached Work Plan Signoff Sheet specific to the 1 ift they will operate.

Although the Fall Protection Work Plan for JLG type lifts has beeri standardized, Prejob Planning documents are still required per KAP 21.12 for all KEH work activities. The standardized Fall Protection Work Plan should be referenced in the Prejob Planning documents. When KEH work activities require the use of rented or loaned JLG type equipment the standardized Fall Protection Work Plan and Work P! an Signoff Sheet must be attached with the Prejob Planning documents.

Please contact myself or your area Safety Representative for any questions or comments. 
TYPE B INVESTIGATION REPORT FOR 241-SY-101 PUMP

START AND 241-C-106 PIT CLEANOUT

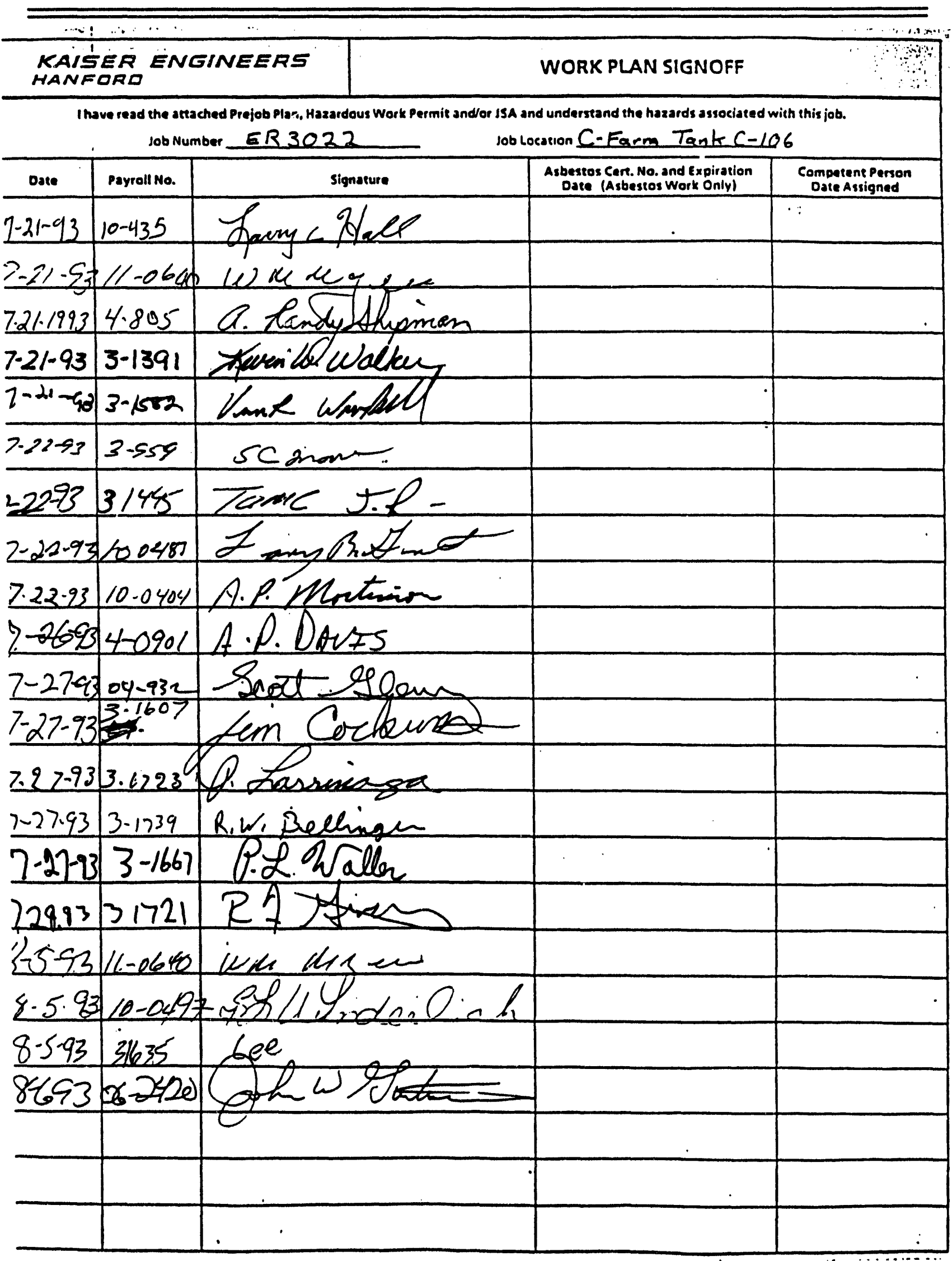


TYPE B INVESTIGATION REPORT FOR 241-SY-101 PUMP START AND 241-C-106 PIT CLEANOUT

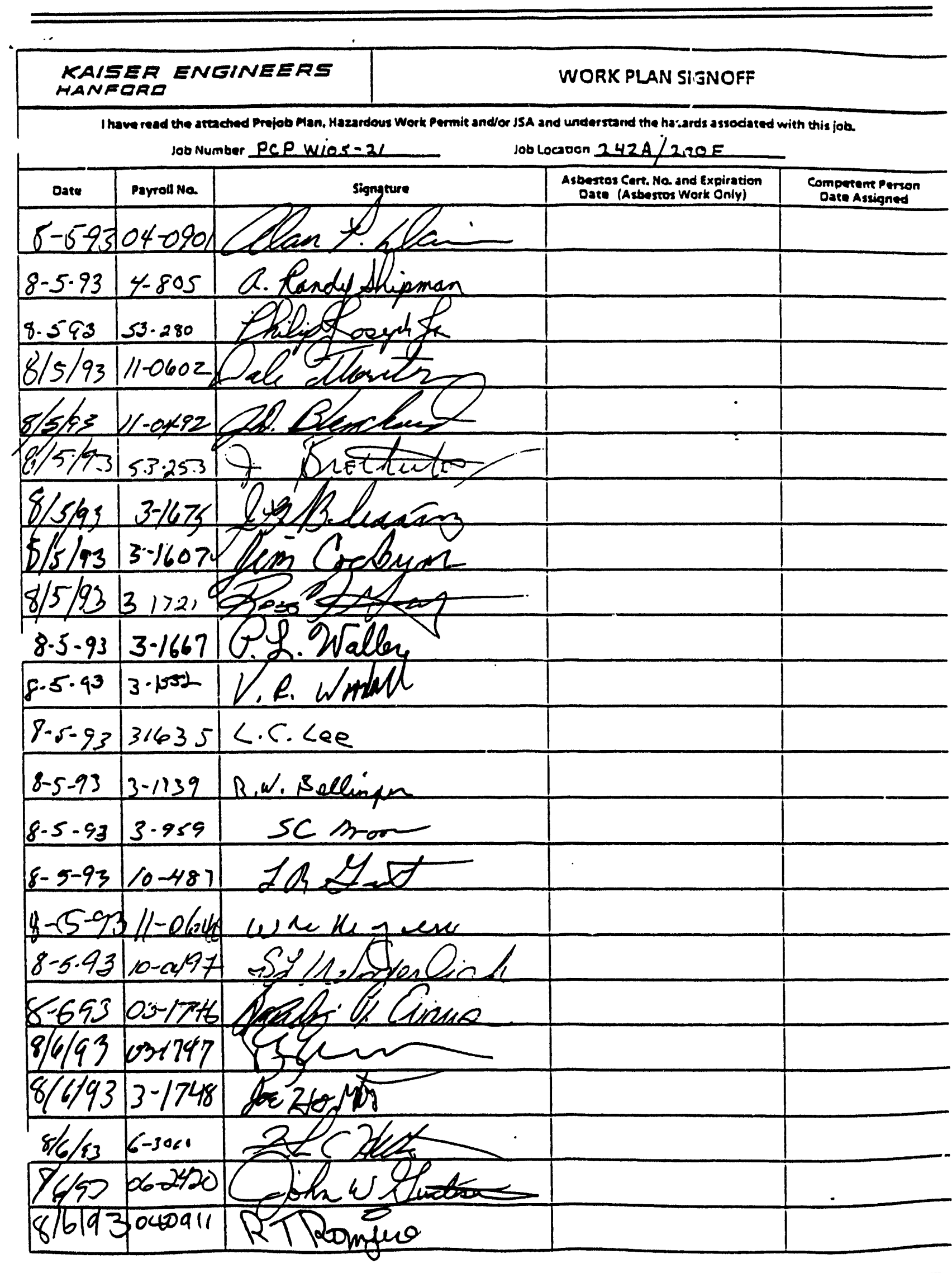


TYPE B INVESTIGATION REPORT FOR 241-SY-101 PUMP

START AND 241-C-106 PIT CLEANOUT

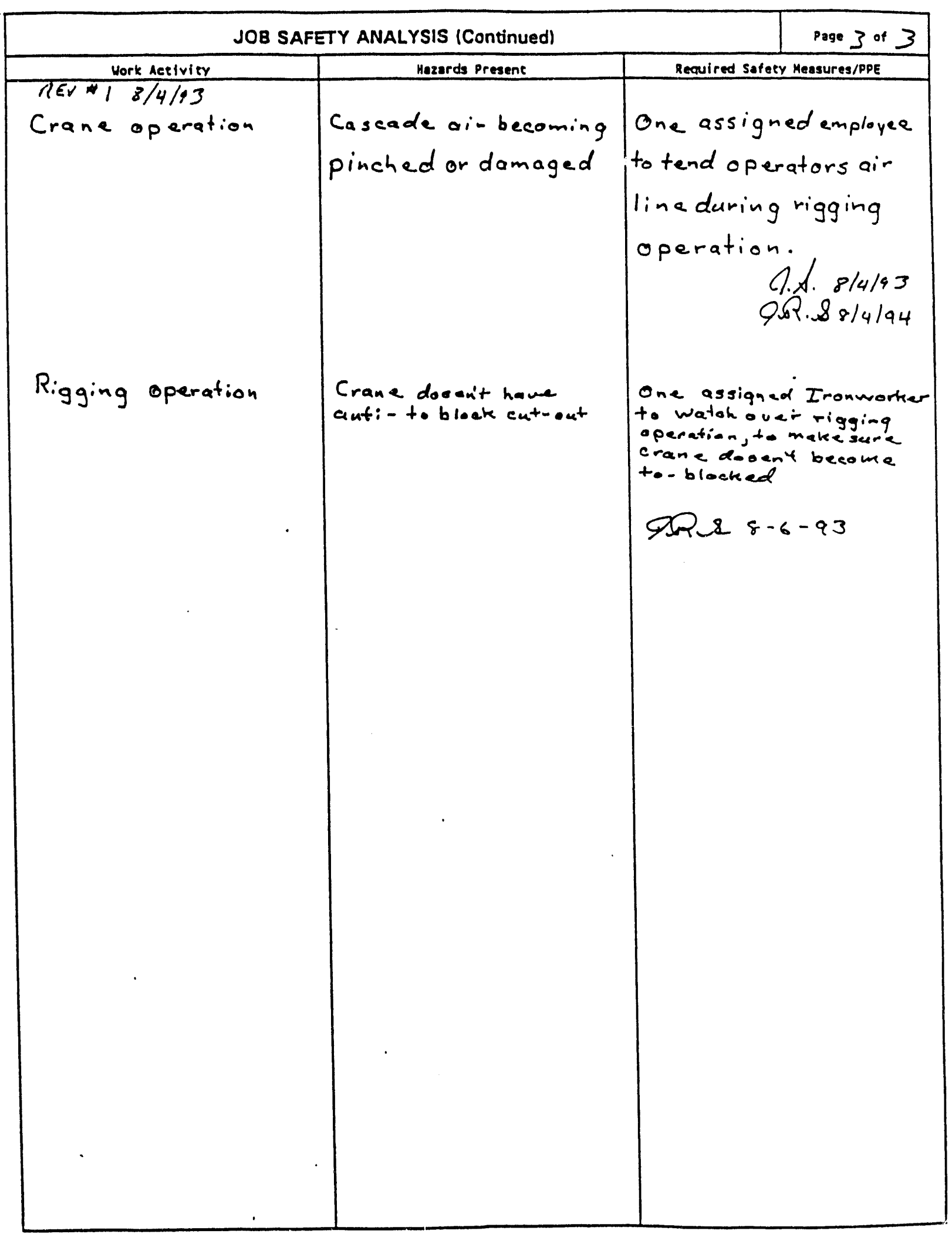

KEN 0898.02 (09/92) KEFO67 


\section{1.}

miñ six I'T -.. Irise II!

:-Getur shedwick-

in : :As

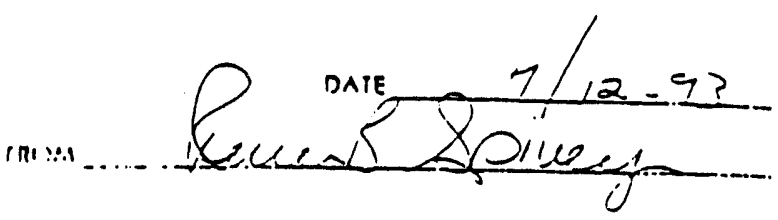

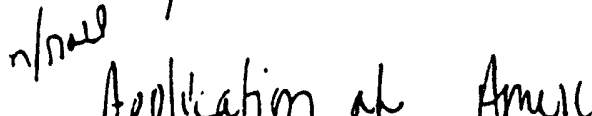

Application ar Amercoat 33. Amercoat 10. Amercsat 187 Ameiciat Rust-Uleum - Rust Refrnmer, and PPG - 6-330 Dafety Y.llow wiel requiris the pallowing:

(1)... Mepeune glow

(2). Splash gogslew

(3) Recommended $\frac{1}{2}$ face cuganic cauthidgerespisatar-productis. contain anganicas that well he invitating to sone ..... inalivideall.

$$
\text { for nit d dors }
$$

TTO) ANYE IIIE IA:T, CIIT BArETY FIRST" 


\section{FALL PROTECTION WORK PLAN}

iE: Employees shall review the requirements of this fall protection work plan prior to starting work. This plan shall be available at the job site during work activities. Also, employees shall be trained and instructed in accordance w/th IS-10. Part E.

JOB LOCATIONIDESCRIPTION: Operation of boom supported elevating work platforms (JLG type aerial lifts).

1. Identify all fall hazards greater than 10 feet in the work area:
[] Leading edge
[] Scaffold erection/disassembly
[] Perimeter edge
[] Stairways
[] Floor openings
[] Ladders
[X] Other: Falls from JLG man basket

2. Method of fall protection to be provided:
[] Fall Restraint
[X] Guardrails
[] Warning Line
$[X]$ Fall Arrest
[] Catch Platform
[] Safety Monitor

Describe: A class III body harness shall be worn by all personnel in the JLG man basket. A lanyard, no longer than six feet, shall be attached to the back "D" ring of the harness and proper attachment point on the JLG platform. Belting off to an adjacent structure or equipment while working from aerial lift shall not be permitted.

u. Descibe the correct procedures for the assembly, maintenance, inspection and disassembly of the fall protection system to be used.

Assembly

All class III full body harnesses shall be worn in accordanc? with the manufacturers recommendations.

\section{Maintenance}

When the full body harnesses and lanyards are not in use they shall be stored so that they are not subject to damage.

Inspection

The user of the fall protection system shall inspect the attachment point, harness, and lanyard prior to use. If defective components are found they shall not be used.

Disassembly

The harness and lanyard shall not be taken off until the JLG is stopped and the man basket is positioned on the ground.

4. Describe the correce procedures for the handling, storage, and securing of tools and materia's:

Tools and materials shall be hand held or stored on the floor of the man basket at all times.

- Describe the method of providing overhead protection for workers who may be in or pass through the area below the work site:

[X] Barricading

[X] Hard hats required

KEN 2118.00 (OS/92) EEPOS1 


\section{FALL PROTECTION WORK PLAN (Continued)}

[] Warning signs [] Toeboards on scaffolds and floor openings

Describe: Hard hats are required for all workers below the overhead work site.

Also, work areas shall be barricaded in accordance with KAP 21.25.

6. Describe the method for prompt. safe removal of injured workers:

$[X]$ Initiate emergency response (811)

[] Utilize lift truck or personnel platform

[] Utilize ladders

[] Utilize scaffolds

[] Use drop lines or retraction devices

Other: In the event of an emergency ground controls can be used to bring injured employees to a safe location.

Approvals:

Fall Protection Plan Completed by: Jeff P. Simundson

Approved by: $\frac{\text { SEE BELW }}{\text { Responsible Supervisor }}$

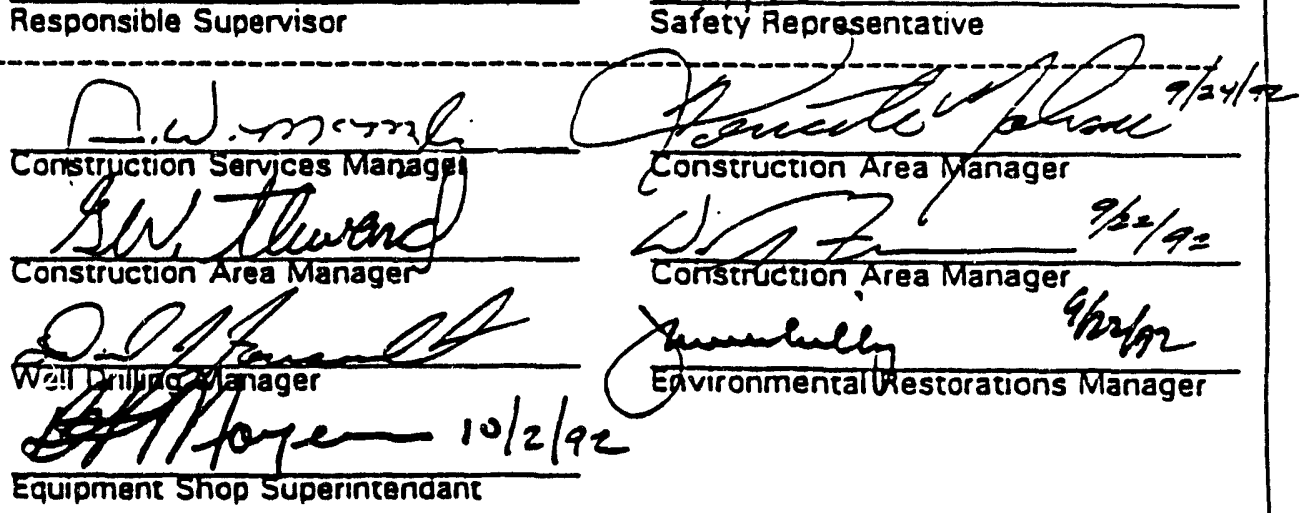

Equpment Shop Superintendant

LEN 2118.01 (05/92) EEFOC! 
TYPE B INVESTIGATION REPORT FOR 241-SY-101 PUMP

START AND 241-C-106 PIT CLEANOUT

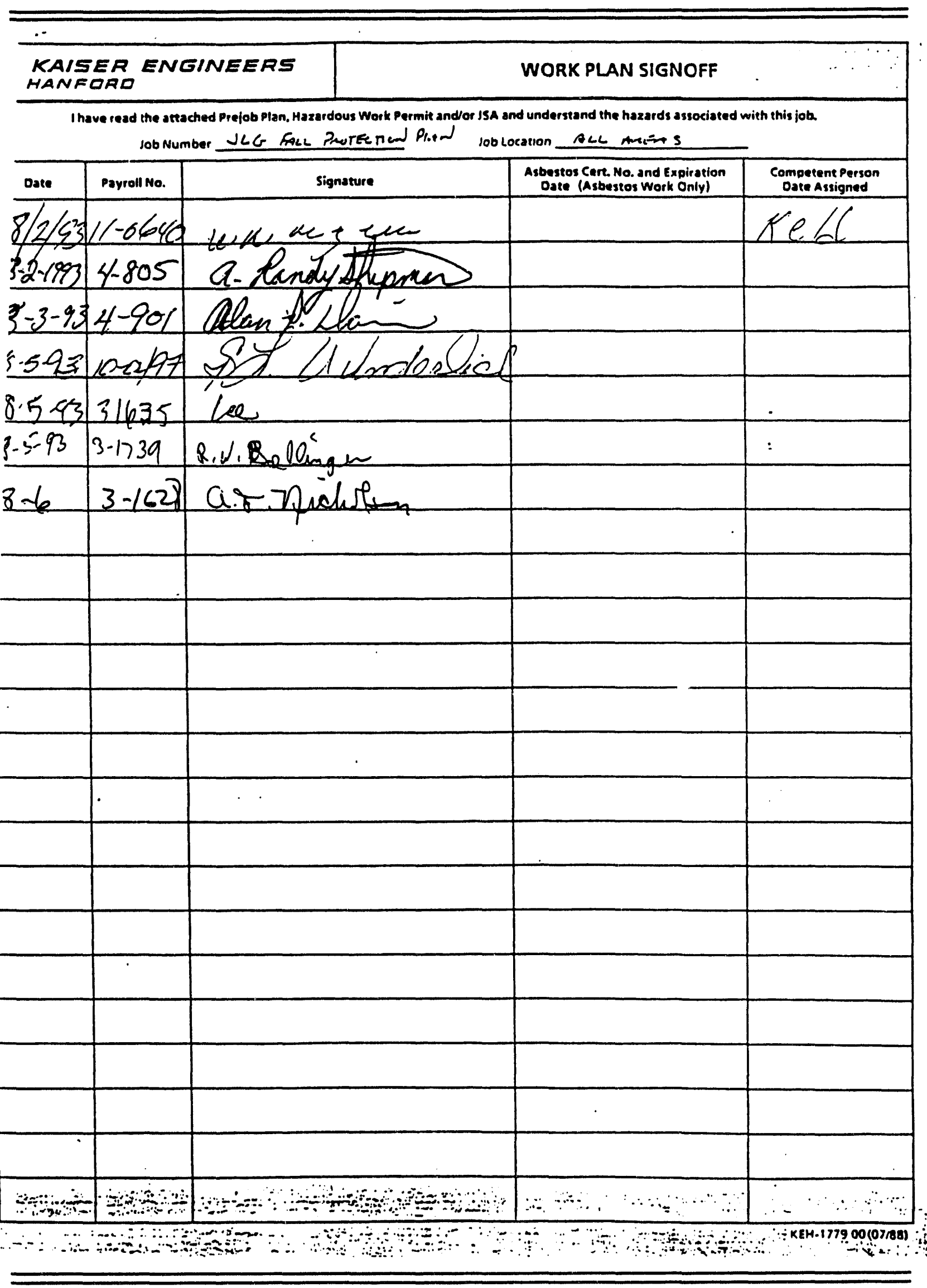




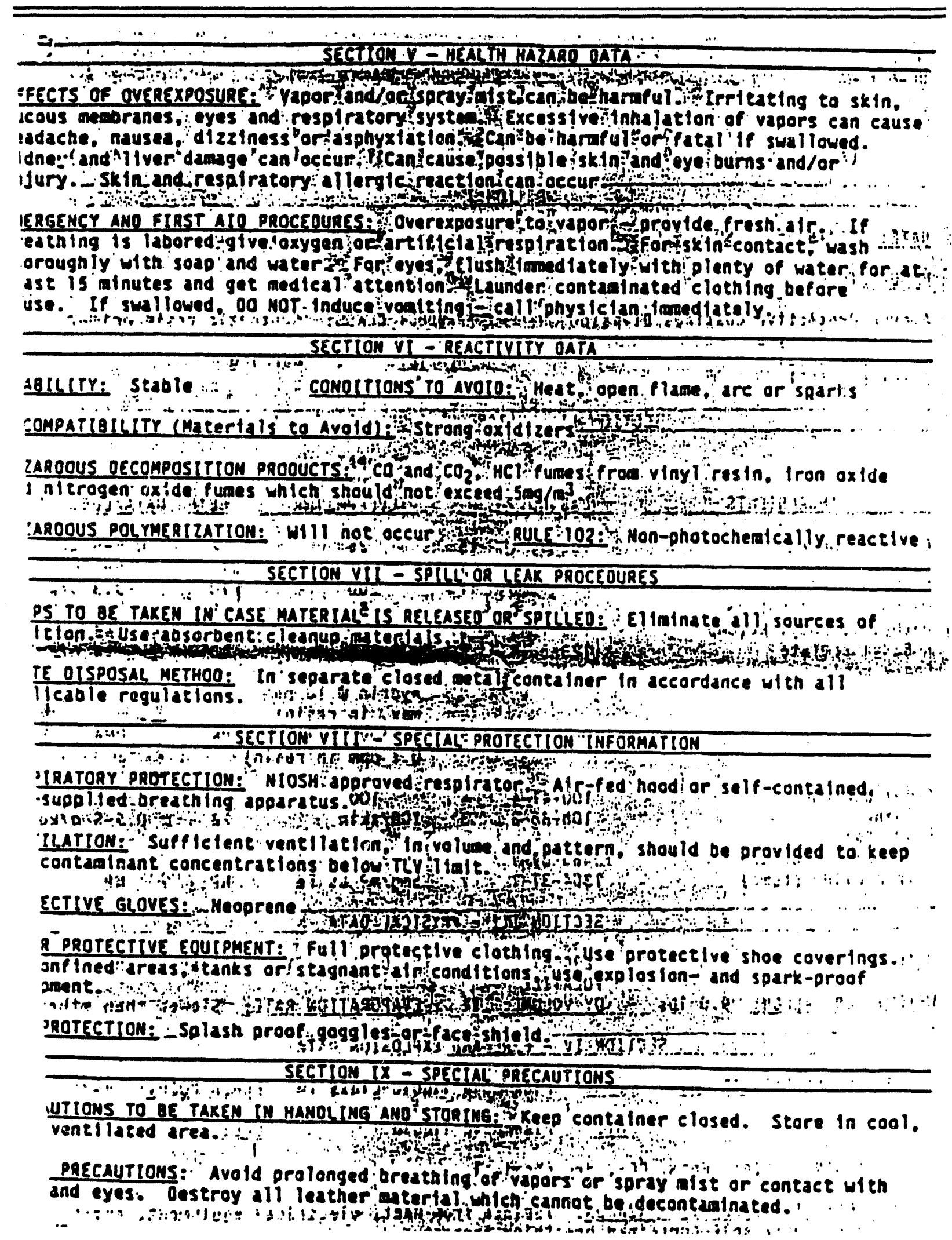


TYPE B INVESTIGATION REPORT FOR 241-SY-101 PUMP START AND 241-C-106 PIT CLEANOUT

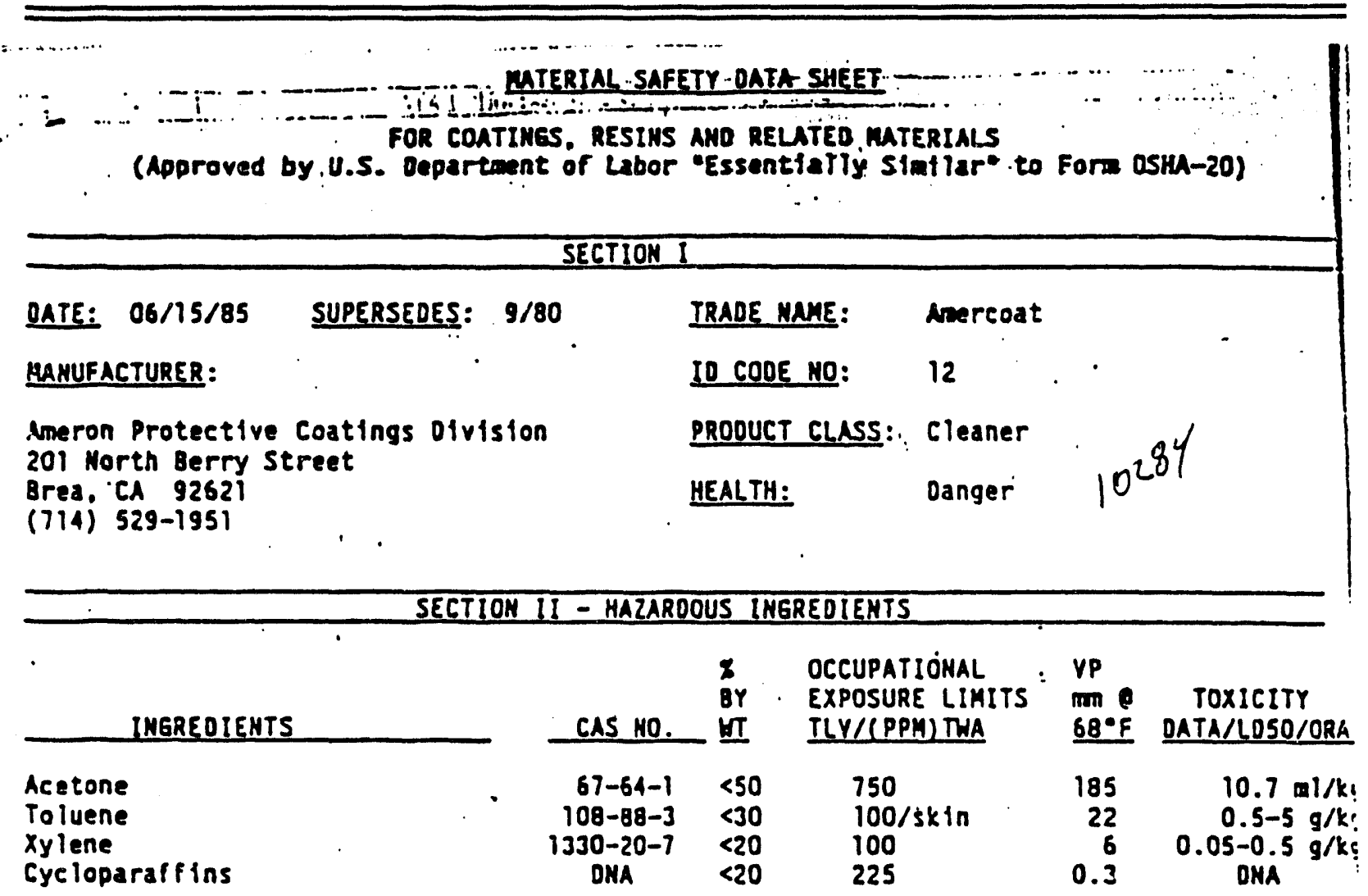

BOILIMG RAHGE: . 134-282 ${ }^{\circ} \mathrm{F}$ PERCENT VAPOR OENSITY: Lighter than air

HEIGHT PER GALLON: 6.8 IbS BY VOLUAE: 100 EYAPORATION RATE: Faster than ether

SECTIOH IY - FIRE AMO EXPLOSIOM DATA

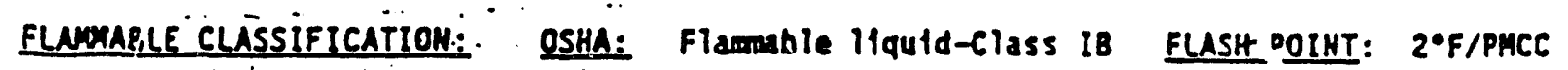

DOT: Flarmable llquidd LEL: 1.3

EXTIMGUISHIMG hF.DIA: Foan, $\mathrm{CO}_{2}$. dry chenical

- 'MUSUAL FIRE AMO EXPLOSIOH HAZAROS: Isolate frem heat, electrical equipment. sparks and pen flase. Mear self-contalned breathing apparatus.

0164r/3 OMA - data not avallable MP - not pertinent 
-.SECTIOH V - HEALTH HRZARD OATA

'iffeTs of overexposuRe: Vapor and/or spray mist can be harmful. Irritating to skin. $\because \div \ldots \cdots:$ mucous membranes. eyes and respiratory system. Excessive inhalation of vapors can cause headache, nausea, dizzlness or asphyxiation. Can be harmful or fatal if swallowed. Kidney and liver damage can oceur.

- EIIERGENCY ALIO FIRST AIO PROCEDURES: Overexposure to vapor - provide fresh air. If b: icihing 15 lajored give oxygen or artifictal respiration. For skin contact, wash ti.uroughiy wth soap and water. For eyes, flush lmedlately with plenty of water for at icast is minutes and get medical. attention. Launder contaminated clothing.before reuse. If swallowed, 00 NOT Induce vomiting - call physictan immediately.

\begin{tabular}{ll}
\hline & SECTION VI - REACTIVITY OATA \\
STABILITY: Stable & CONOITIONS TO AVOIO: Heat, open flame, arC or sparKs
\end{tabular}

li:COMPATIBILITY (Materials to Avold): Strong oxidizers, alkalies

HE.ZAROOUS DECOMPOSITION PRODUCTS: $\mathrm{CO}$ and $\mathrm{CO}_{2}$

HAZAROOUS POLYMERIZATION: WHII nOt OCCUR RULE 102: Photochemicallý reactive

$$
\text { SECTION VII - SPILL OR LEAK PROCEDURES }
$$

STEPS TO BE TAKEN IN CASE MATERIAL IS RELEASED OR SPILLEO: Eliminate all sourCES of. Ignition. Use absorbent cleanup materials.

WASTE OISPOSAL HETHOO: In separate closed metal container in accordance with all applicable regulations. SECTION VIII - SPECIAL PROTECTION IHFORMATION

RESPIRATORY PROTECTION: NIOSH APPROved reSPirator. 'In confined areas, tanks or stagnant air conditions, use alrline hood-type respirator.

VEMTILATION: Suffictent ventilation, in volume and pattern, should be provided to keep alr contaminant concentrations below TLV 1 imit.

\section{PROTECTIVE GLOVES: NeOprene}

OTHER PROTECTIVE EOUIPMENT: Coveralls. In confined areas, tanks or stagnant air conditions, use exploston and spark-proof equipment.

EYE PROTECTION: Splash proof goggles or face shield. SECTION IX - SPECIAL PRECAUTIONS

PRECAUTIONS TO BE TAKEN IN HAMOLIHG AHO STORIHG: Keep contalner closed when not in use. Store in cool, dry, well-ventllated area.

OTHER PRECAUTIONS: Avold prolonged breathing of vapors or spray mist or contact with skin and eyes. 
TYPE B INVESTIGATION REPORT FOR 241-SY-101 PUMP

START AND 241-C-106 PIT CLEANOUT

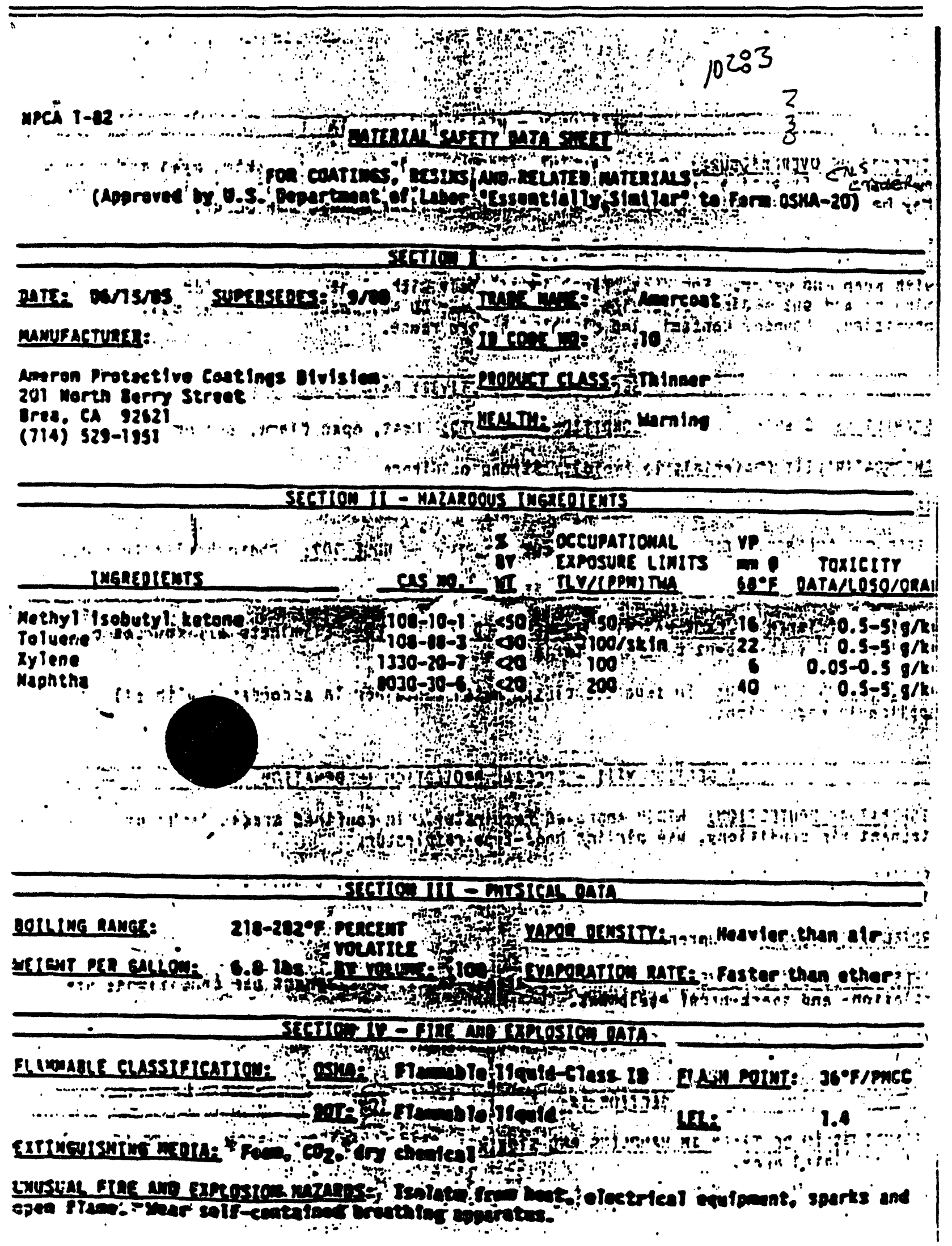




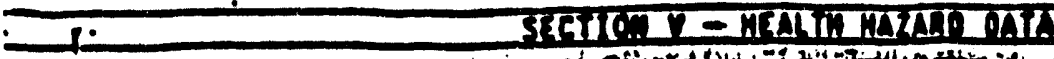

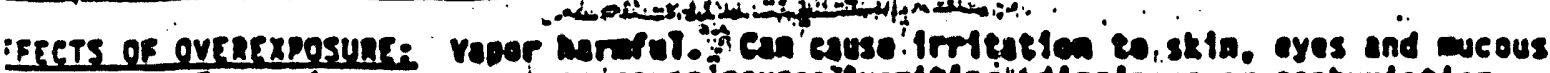

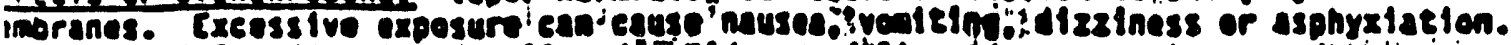

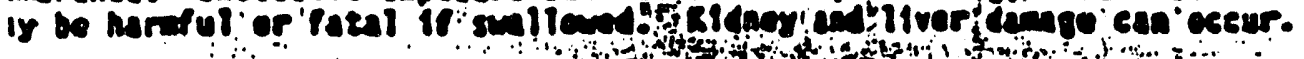

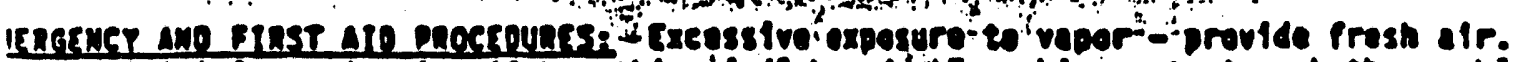

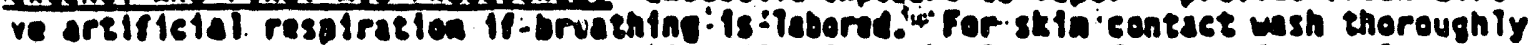
en soap and wear. For oyes. flysh! fundiately ulth plentyi of water for at least is

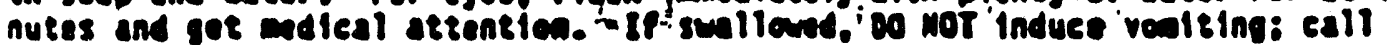
iystetan. Launder contevinated elothing defore rause...

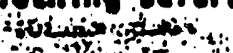

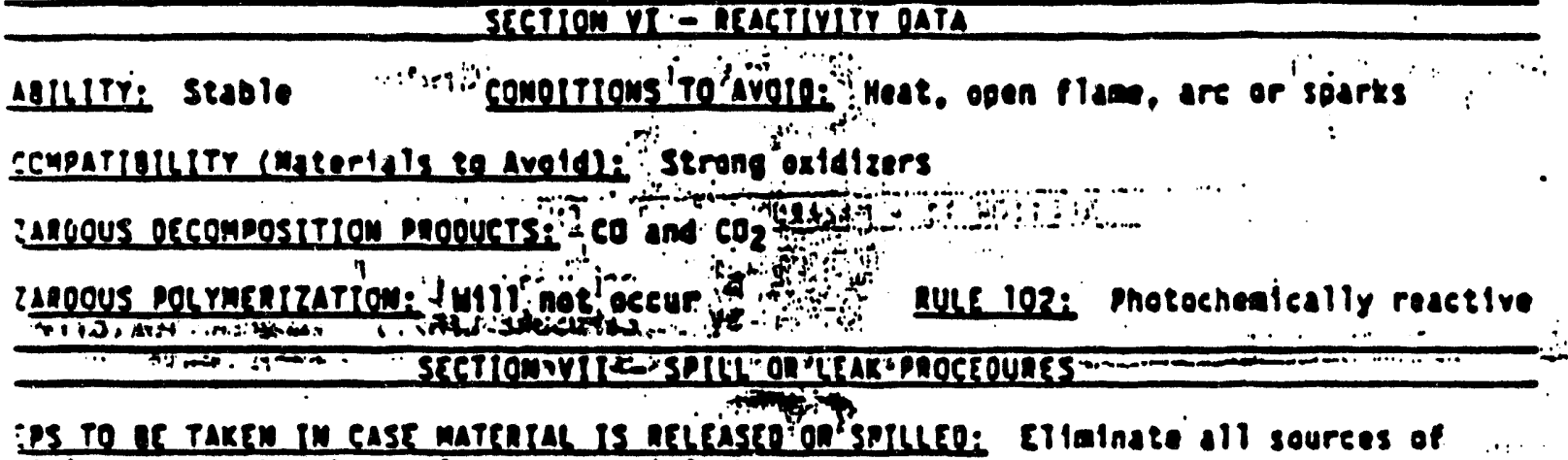

1teron: Use opsorbene elesnun'

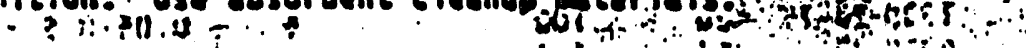

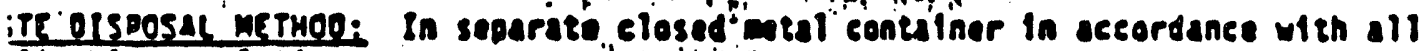

illeable requlations.

\section{SECTIOU VIII - SPCCTAL PROTRETION IMFORMATIOA}

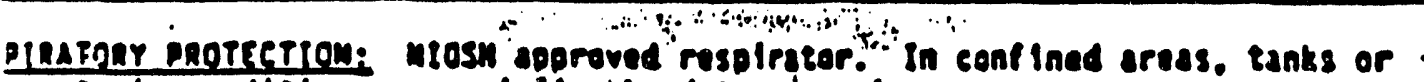
gndent atr candistons. use ofrline hoed-eypoipgsipter.

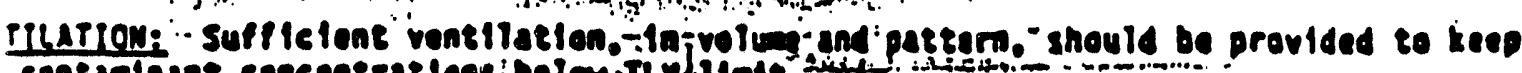

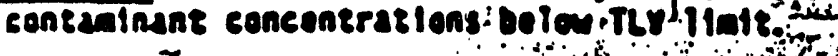

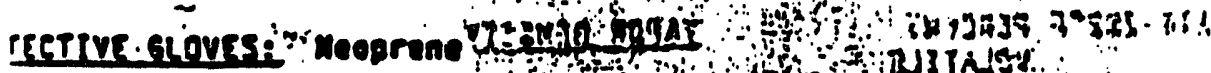

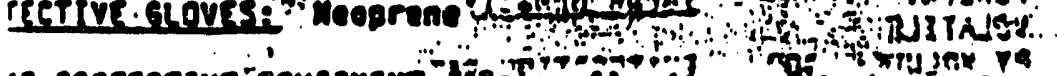

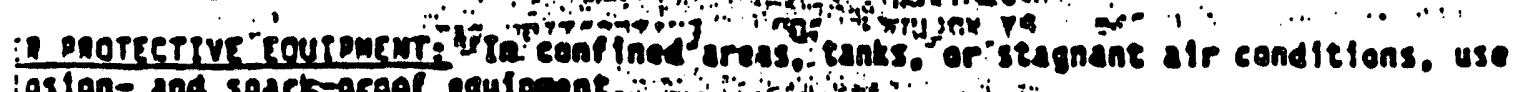

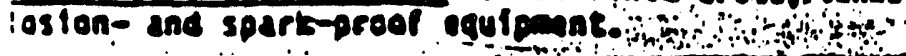

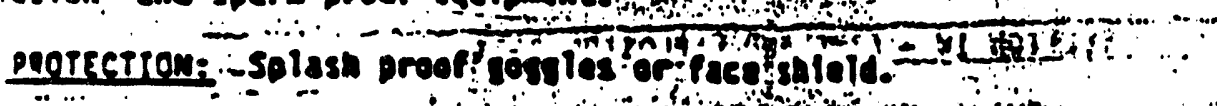

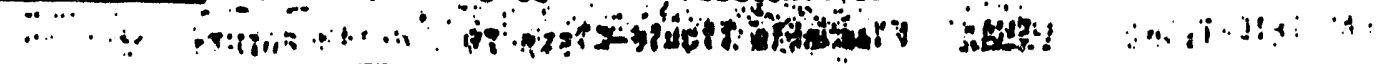

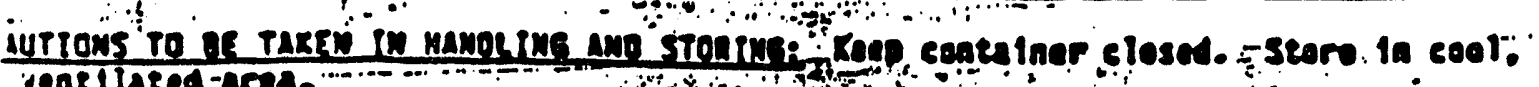

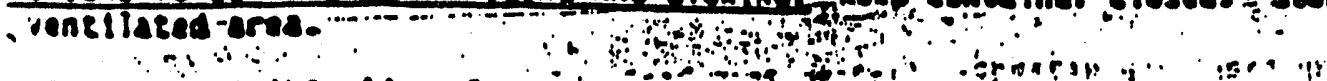

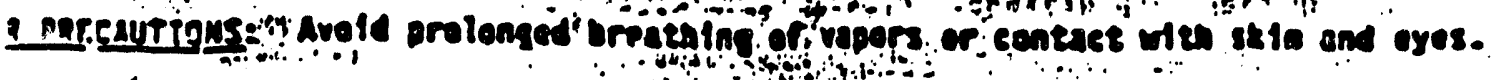




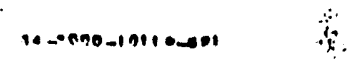

DONTI SAY IT' -.. ITrise: It!

10. - Man shedwick-

rnis.

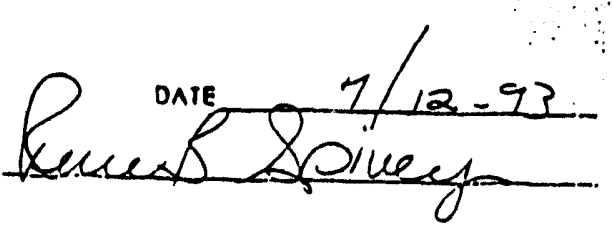

sh/nol

Application... Amercoat 33, Amercoat 10, Amercuat 187, muecicoat

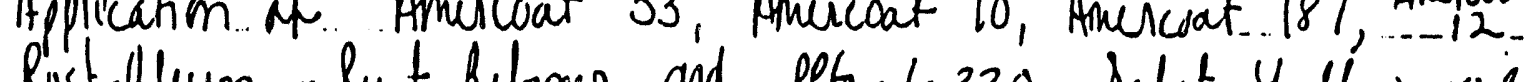
Rost-Olum - Rust Refrnmes, and PPG - 6-330 bafety Yellow coile Mquaile the pellowing:

(1). Necpene... glowes

(2) Splash goggles

(3) Recommended $\frac{1}{2}$ face arganic cautidgerespisatior-a produdsts contain arganics that well he invitating to sone inaliciderall.

for ont id dons.

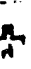

TO) MAKE IIIE LAST, rIT SAYEIY FIRST'

$+$ 


\section{TYPE B INVESTIGATION REPORT FOR 241-SY-101 PUMP START AND 241-C-106 PIT CLEANOUT}

Borrers of ovrproposurs:

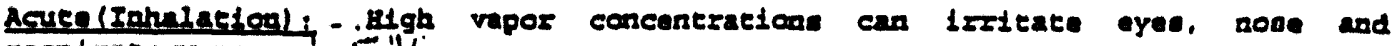

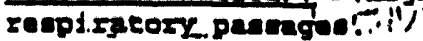

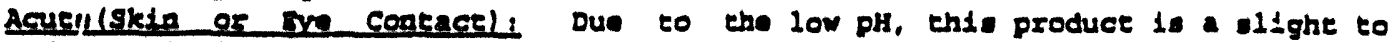
modarate irriteant in rapeated contact.

Ingunet on- Noa-torde

Crronte. None recognised

MSDS \#30306

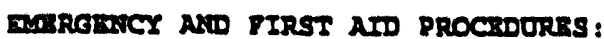

Dumer: Remove Erom exponure.

Spray (exen); Pluah Imaddately with large amounts of water for at lasat 15 minutes. Notisy a physician.

Splechlakta); Wan aflected area with woap and water and ramove contaminated cloening. If radaese, leching or burning seneacion davelopen conault a phyaician' and have chis laformation available.

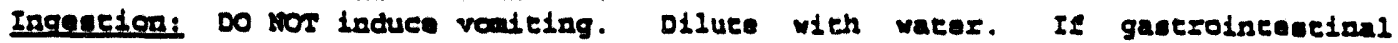
yupecans develop, contace a phyeician. Never give anyehing by mouth to an unconectoun pornos.

SECTION VI-REACFIVTEY DATA

Hazardous Deccmposition Produces: By Elame-Carbon monoxide and Carbon tioxide Hazardoue Polymartzation: WIIl Not Occur

\section{SECLION VII-SPIII OR WEAK PROCSDORTS}

Releene of Spill procedures: Soak up liquid with aboorbeat and shovel inco waste container. Wash epill axea with water and llunh to sewer serviced by wastevater troatment tactlity.

Warte Disponal Method: Dispose of according to local, stace and federal regulactous.

SECTION VIII-SPECIAL PROTECTION IITPORYATION

Regplratelory Procection: One MrOsH approved chemical cartridge respiracor to remove wolid airborae particles of overupray during epray application.

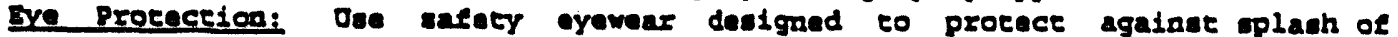
liquide:

Other Protective Bquipment: Oee gloved to prevent prolonged skin contace. Venet. Iation: Provido goneral dilueton or local exhauat veneilation in volume and pactern to keep IIV of hazardous ingrediencs below acceptable ifenite.

SECTIOT IX-SPECIAL PRECAOTIONS ANT REGULATORY ISSUES

Handiting and storage Precautiona: Mon-Llamable. See OSHA 2910.106. Keep from FREEzING. -

Other Requlatione: Peanoylvania/kew Jersoy Righe-To-Know lawe- Other ingredienes in this produce such an resin, pigmene ant additives are nonharardous and considered trade secrete under these regulations. 
men i.es $\cos 1 \mathrm{n} 1 / 1)$

maienial sareir oala sikel

ron coarlings. acsins ano aclaite micaials

MSDS \#10288A

Mereon Prolectlua Coal Ings 20 Horth Berry street Drea. Ca 92821

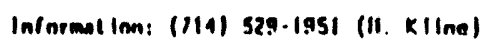

(merganey: (000) 124.9300 (CIEHIRfe)

Preporation Date: $03 \cdot 09 \cdot 90$

Suporsedes: $03 \cdot 10 \cdot 89$

secrion 1 .. promict loentiricallon

iano mave: areacoas

monicl ciass: Vinte corol rmen

provur.1 no: 33
rOM IMOUSIAIAL USE OHLY IEAL III: MARMIMG

stcrion II - IMLneoous imgaenieilis

\begin{tabular}{|c|c|c|c|c|c|c|c|c|c|}
\hline \multirow[b]{3}{*}{ Imeacnienis } & \multirow{3}{*}{$\begin{array}{l}\text { cas } \\
\text { mo. }\end{array}$} & \multirow{3}{*}{$\begin{array}{l}x \\
\text { or } \\
\text { ui }\end{array}$} & \multirow{2}{*}{\multicolumn{2}{|c|}{$\begin{array}{l}\text { osiua } \\
\text { pet }\end{array}$}} & \multirow{2}{*}{\multicolumn{2}{|c|}{$\begin{array}{l}\text { ACOIII } \\
\text { IU (INA) }\end{array}$}} & \multirow{3}{*}{$\lim _{60}:$} & \multicolumn{2}{|c|}{ inxicily. } \\
\hline & & & & & & & & 1050 & teso \\
\hline & & & mpom & $\mathbf{m} / \mathbf{m}$ & pnom & $m g / m s$ & & g/kg & \\
\hline 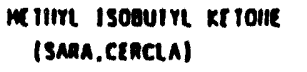 & $108-10-1$ & 31.23 & so & 203 & 50 & 205 & 15 & 2 & 000 \\
\hline 10018me & $104-88-3$ & 17.91 & 100 & $3 / 5$ & 100 & $3 / 5$ & 24 & 5 & 000 \\
\hline (SAMA.CencLa) & & & & (BEMLEM & $\boldsymbol{n} \bullet \boldsymbol{0}$ & $0.900 \mathrm{rPHI}$ & & & \\
\hline CIN On Imaled PMAaFrin & $61788-78=9$ & .15 & has & $\begin{array}{l}\text { dns } \\
\text { (As pM }\end{array}$ & dis & 2 & na & so & din \\
\hline IIAMIIOA oloxioe & $\mid 3463-87-7$ & .15 & the & 10 & dine & 10 & na & 24 & 3020 \\
\hline$a$ & & & & $\begin{array}{l}\text { (AS II. } \\
\text { (AMonpir }\end{array}$ & $\begin{array}{l}\text { rossio } \\
\text { contis). }\end{array}$ & 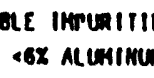 & 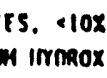 & $\begin{array}{l}x \text { silics } \\
x(0,\})\end{array}$ & $\wedge$ \\
\hline $\begin{array}{l}\text { VInYt CInOnIOC REsin } \\
\text { (SMeA,CERCLA) }\end{array}$ & $9005 \cdot 05-8$ & .15 & 1 & $\begin{array}{l}\text { the } \\
\text { ive. }\end{array}$ & 0.18 & 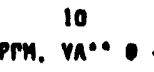 & $\begin{array}{c}n 0 \\
<0.5 \times 1\end{array}$ & dne & dinn. \\
\hline$\underset{\text { (SAAA) }}{\operatorname{xreme}}$ & $1330-20-7$ & 0.47 & 100 & $\begin{array}{l}\text { L35 } \\
\text { iatmene }\end{array}$ & 100 & $\begin{array}{c}435 \\
0.900 \mathrm{PPH}\end{array}$ & 6.6 & 4.3 & 6700 \\
\hline m s e mapililu & $64742-48-9$ & 7.16 & 500 & coemetm & 300 & $\begin{array}{c}1350 \\
0.900 \mathrm{rmH}\end{array}$ & 5.2 & 5 & 3400 \\
\hline - cimoniun oxide & $1300-38-9$ & 410 & dna & $\begin{array}{l}0.5 \\
\text { (As ca) }\end{array}$ & dne & 0.5 & na & die & dna \\
\hline 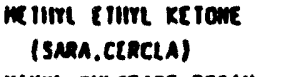 & $78-99-3$ & 5.68 & 200 & 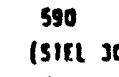 & 200 & 590 & 10 & 2.7 & 2000 \\
\hline $\begin{array}{l}\text { VImRL CiRmioe Resin } \\
\text { (sman.ceneta) }\end{array}$ & $9003-22-9$ & $<10$ & 1 & $\begin{array}{l}\text { dine } \\
\text { ive.* }\end{array}$ & 15 & $n=$ mine. & 0.321 & dne & Jna \\
\hline - Inom axioe & $|302-3|-1$ & $<10$ & $\operatorname{lna}$ & las ie r & rove & 5 & no & dna & die \\
\hline HICA & $12001-28 \cdot 2$ & 410 & dne & $3^{3}$ & dine & 3 & no & na & diee \\
\hline - cAMEON al ACR - & $1333-86-4$ & .5 & chis & 3.5 & eline & 3.5 & no & dine & diea \\
\hline $\begin{array}{l}\text { Cancer or Suspected Cance } \\
\text { Ret. Aitc, aceill, red os } \\
\text {-a calir. IIIIE 26: 22-1 }\end{array}$ & ent: no & & Plgment & content & Is depe & emilent on co & lor. & & \\
\hline
\end{tabular}

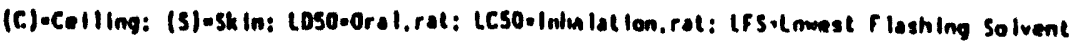




\section{TYPE B INVESTIGATION REPORT FOR 241-SY-101 PUMP START AND 241-C-106 PIT CLEANOUT}

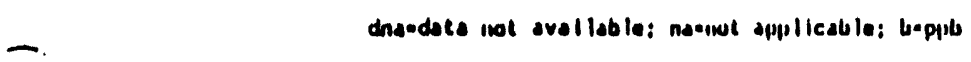

MSDS \#10288A

Propucl 10: 33

MIERIAL SATETY DAIA SIKE!

Page: 2

SECTION III -- PIIYSICA DAIA

80ll IMO Ranas: 175-282 0eg. F

volallie volum $x: 19$

vI Per cal: 8.0-8.8 Las

Appenance: L lquld

sutualliti if valen: no

rapon densilty: lleavler llian alr

evaponalion gate: Butyl acelale - I

IOV: 0.10 HIGII: 4.60

ooun: Solvent

secilon iv -. Fine ano cxplosion oala

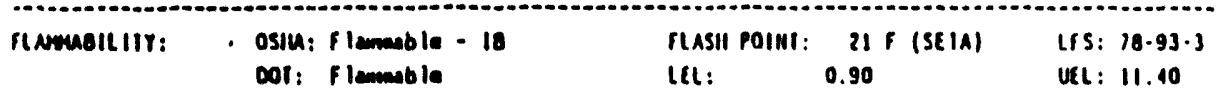

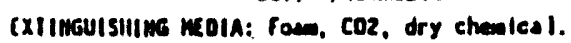

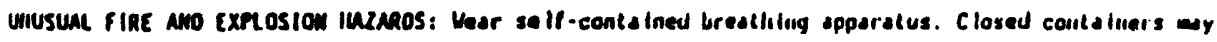

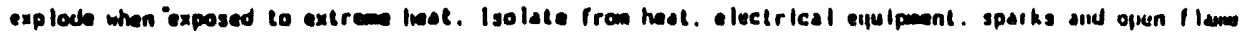
keep upwind. Vepors eay spreed lone dlstances. Cause flasti flre or lgulle explosively.

SECIJON $\vee--$ ILALIII IMZARO DAIA

Chiar Roules: Inhulietion and sk in contact.

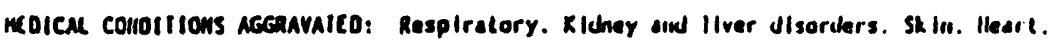

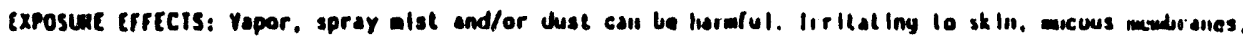

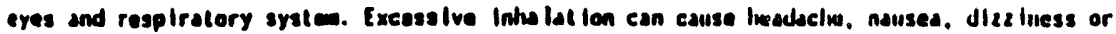

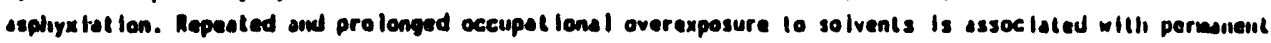

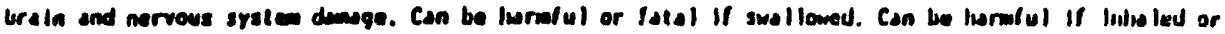

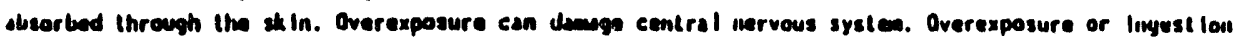

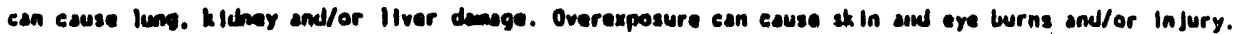
Overexposure can cawse deloyed ling Injury.

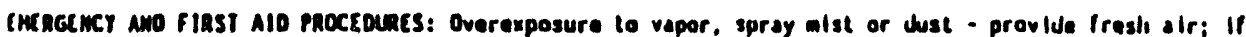
brealling labored, glve oxygen or artiflelal resplratlou. for sk in contact. wash llorouglaly wlth soap

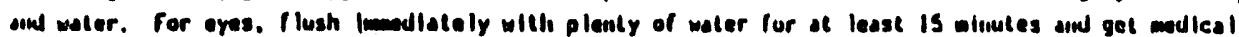

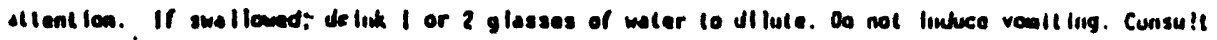

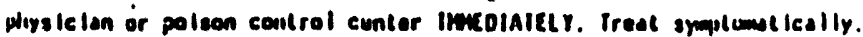

\section{SECrion $V 1$-- REACIIVIII OAIA}

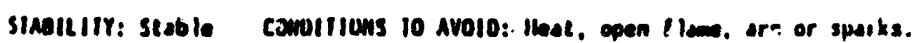

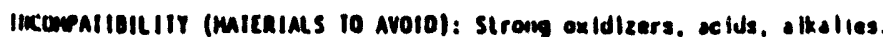

$\rightarrow$

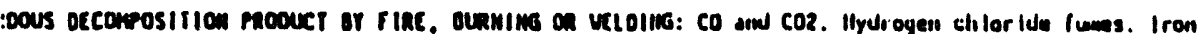
itumes.

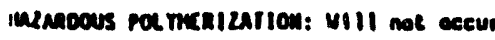

stetion vil -- splll on Ifax moctormes 


\section{TYPE B INVESTIGATION REPORT FOR 241-SY-101 PUMP START AND 241-C-106 PIT CLEANOUT}

.3. LeNks: Avold hreathing of vapors or dust. Use obsorbent cleanup meter iols or aweep up. place In ite contalmer. Reep out of publle semers and waterways. If entry is threatened or occurs, notify outhortl les. Iliminate 11 sources of Ignition.

MSDS \#10288A

raonici no: 33

MIERIAL SAREIY OAIA SIKET

Page: 3

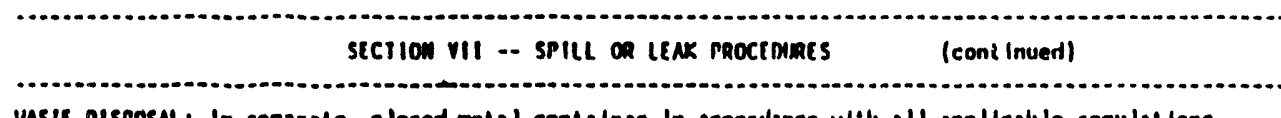

Uasit olsposat: In separale. e losed watal contalner In accordance will all applleable regulat lons.

CPA UASIE 10: 11001 U161 U220 U239 U159

\section{secrion vill -. speciat protecilon Irronmilion}

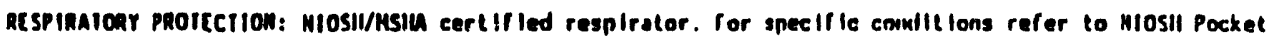

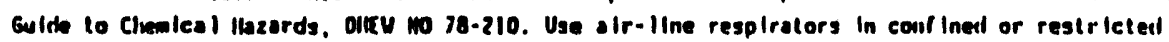
vewillation areas. or with polyurethane or lsocyanates. Refer to $29 \mathrm{crh}$. Osil parts 1910. 19is. and 1916 for cost ing operatlons.

"IIIAlion: Sufflelent ventllation. in volum and pattern. simuld be provided to keep a Ir contaminont

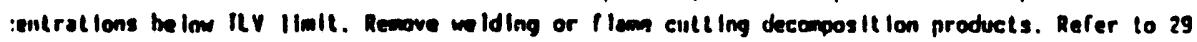
..A. OSIM parts 1910. 1915. and 1916 for coat Ing oparstlons.

Paotective Gloves: Neoprene or other sultable antertals.

ire proitcilon: Splash-proof goggles or face shield.

olikn reoiecilve coutraent ron apmicasion on CLEAmur: rull protect lve clolling. Spark-prool equ lpment.

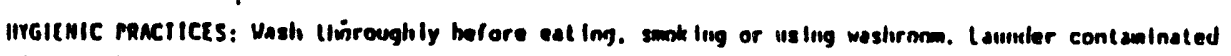
clotliling before reuse.

seciion ix -- srecial racraulions

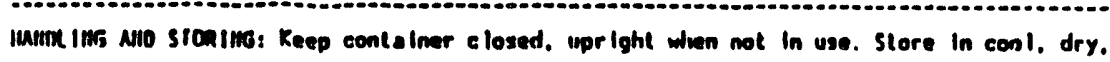
will-vent l lated eree. Avold storage temperatures ahove 100 degrees ralirenlielt.

nilke parcautions: Do nol lake Internolly. Avold prolonged hreatling of dust, vapors or spray alst or

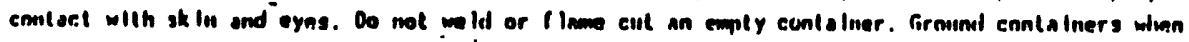
pour ing. 
TYPE B INVESTIGATION REPORT FOR 241-SY-101 PUMP

START AND 241-C-106 PIT CLEANOUT

This page intentionally left blank. 


\section{DISTRIBUTION}

\section{Number of Copies}

\section{ONSITE}

2

U.S. Department of Energy

Richland Field Office

J. D. Wagoner, RL

A7-50

4

Kaiser Engineers Hanford

C. E. Anderson

G7-11

L. J. Garvin

G7-01

D. W. McMyler

S2-53

C. E. Upchurch

G7-40

Westinghouse Hanford Company

W. T. Alumkal

R2-52

T. M. Anderson

B3-01

R. J. Bliss

B3-04

J. G. Burk

B3-25

J. G. Cassady

B3-07

T. O. Elsethagen

A2-50

J. R. Ewalt

B5-21

J. C. Fulton

R2-31

J. W. Hagan

B3-55

H. D. Harmon

R2-52

G. A. Harvey

B4-52

K. R. Jordan

B2-30

M. K. Korenko

B3-08

H. E. McGuire

B3-63

S. R. Moreno

B3-06

S. R. Morgan

R2-50

D. J. Newland

R2-36

M. A. Payne

R2-50

D. H. Shuford

T7-09

M. A. Siano

G6-02

R. G. Slocum

B5-21 


\section{DISTRIBUTION (Continued)}

Westinghouse Hanford Company (Continued)

D. J. Swaim

B3-51

A. L. Trego

B3-02

E. P. Vodney

B3-50

Correspondence Control (2)

A3-01 

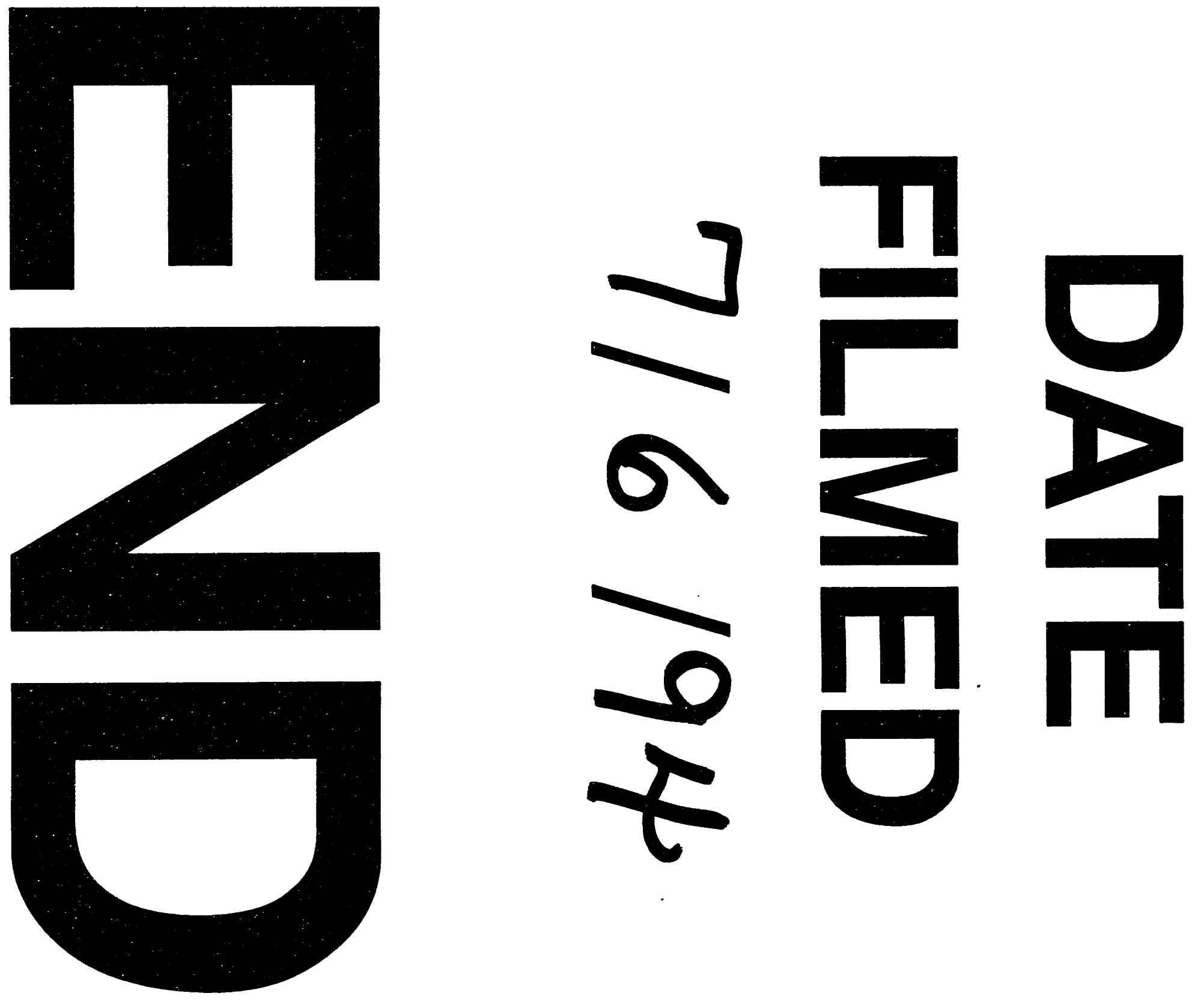


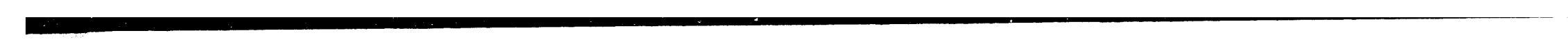

1 